\title{
GEOHYDROLOGY AND VERTICAL DISTRIBUTION OF VOLATILE ORGANIC COMPOUNDS IN GROUND WATER, FISCHER AND PORTER COMPANY SUPERFUND SITE, WARMINSTER, BUCKS COUNTY, PENNSYLVANIA
}

By Ronald A. Sloto, Paola Macchiaroli, and Randall W. Conger

U.S. GEOLOGICAL SURVEY

Water-Resources Investigations Report 95-4220

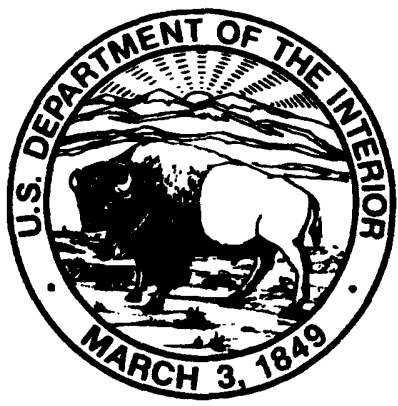

Prepared in cooperation with the

U.S. Environmental Protection Agency 


\title{
U.S. DEPARTMENT OF THE INTERIOR \\ BRUCE BABBITT, Secretary
}

\author{
U.S. GEOLOGICAL SURVEY \\ Gordon P. Eaton, Director
}

For additional information write to:

District Chief

U.S. Geological Survey

840 Market Street

Lemoyne, Pennsylvania 17043-1586
Copies of this report may be purchased from:

\section{U.S. Geological Survey}

Earth Science Information Center

Open-File Reports Section

Box 25286, MS 517

Denver Federal Center

Denver, Colorado 80225 


\section{CONTENTS}

Page

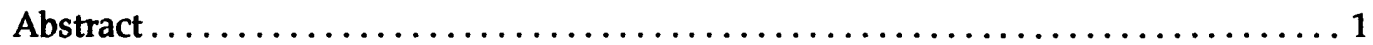

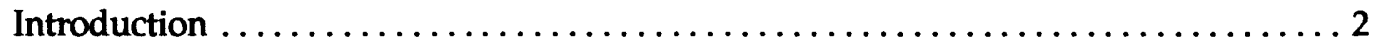

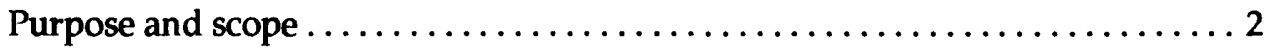

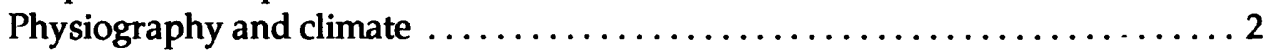

Previous ground-water investigations $\ldots \ldots \ldots \ldots \ldots \ldots \ldots \ldots \ldots \ldots \ldots \ldots$

Acknowledgments ............................. 4

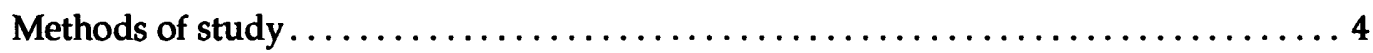

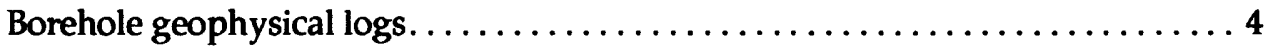

Caliper logs $\ldots \ldots \ldots \ldots \ldots \ldots \ldots \ldots \ldots \ldots \ldots \ldots \ldots \ldots \ldots \ldots$

Natural-gamma logs. .............................

Single-point-resistance logs. $\ldots \ldots \ldots \ldots \ldots \ldots \ldots \ldots \ldots \ldots \ldots \ldots$

Fluid-resistivity logs. ..........................

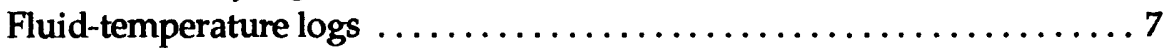

Measurement of borehole flow. .........................

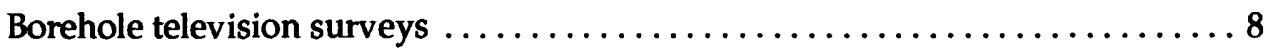

Location of deep exploratory boreholes and coreholes $\ldots \ldots \ldots \ldots \ldots \ldots \ldots 8$

Monitor well drilling and construction. ........................

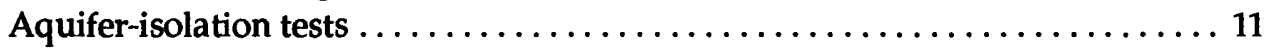

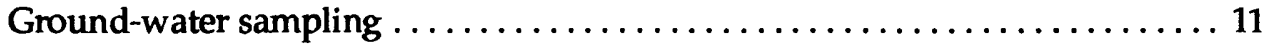

Water-level measurements . . . . . . . . . . . . . . . . . . . . . . 11

Geology and geohydrology $\ldots \ldots \ldots \ldots \ldots \ldots \ldots \ldots \ldots \ldots \ldots \ldots \ldots \ldots \ldots \ldots$

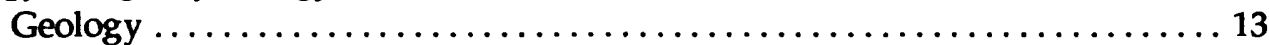

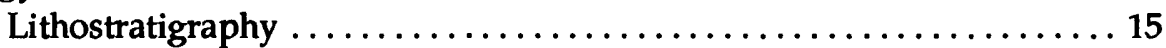

Generalized stratigraphic model $\ldots \ldots \ldots \ldots \ldots \ldots \ldots \ldots \ldots \ldots \ldots \ldots$

Geohydrology ..................................... 16

Geohydrology at existing boreholes $\ldots \ldots \ldots \ldots \ldots \ldots \ldots \ldots \ldots \ldots \ldots$

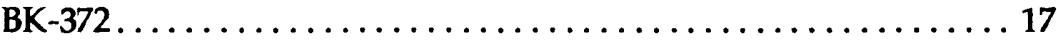

BK-1324.......................... 17

BK-1731 ............................ 18

BK-1795 ...................................... 19

BK-1796............................... 19

MG-1241 .................................... 19

MG-1242 ................................. 20

Geohydrology at exploratory boreholes $\ldots \ldots \ldots \ldots \ldots \ldots \ldots \ldots 23$

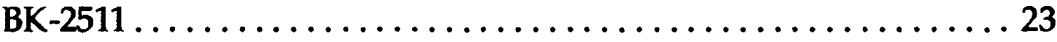

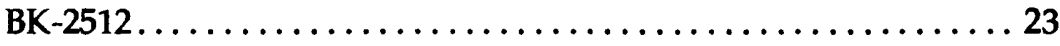

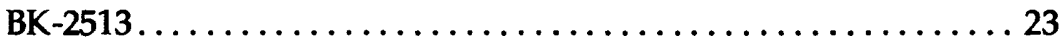

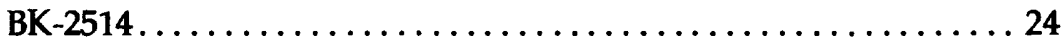

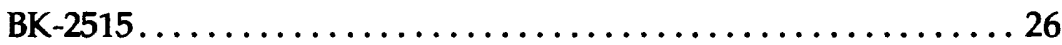




\section{CONTENTS-Continued}

Geology and geohydrology-Continued

Geohydrology-Continued

Vertical distribution of specific capacity $\ldots \ldots \ldots \ldots \ldots \ldots \ldots \ldots 27$

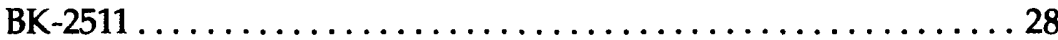

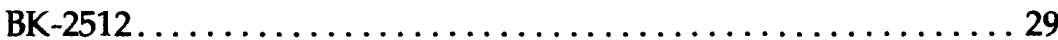

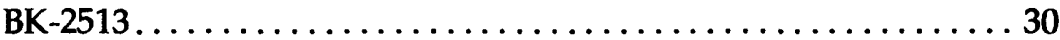

BK-2514........................................ 31

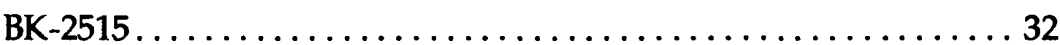

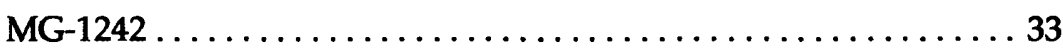

Water levels ...................................... 34

Water levels at monitor well clusters and boreholes ........ 36

BK-2511, BK-2521, and BK-1731................. 36

BK-2515, BK-2527, and BK-2528 ................ 37

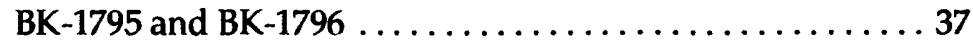

BK-2514 and BK-2526 ........................ 37

BK-1793 ................................ 38

BK-2513, BK-2524, and BK-2525 .............. 38

BK-2512, BK-2522, and BK-2523 ............... 38

Effect of pumping the Fischer and Porter treatment system

wells on water levels............................ 39

Synoptic water-level measurements................ 42

Vertical distribution of volatile organic compounds $\ldots \ldots \ldots \ldots \ldots \ldots \ldots \ldots \ldots$

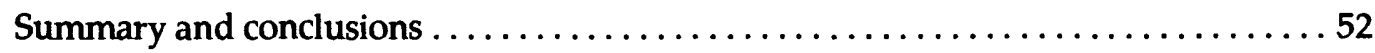

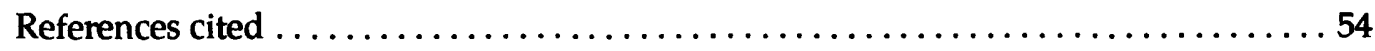

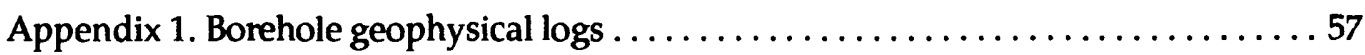

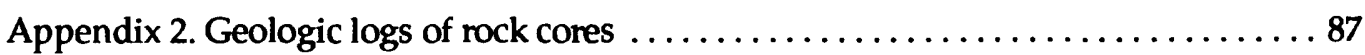

Appendix 3. Geologic logs of exploratory boreholes . . . . . . . . . . . . . 95

Appendix 4. Water-level hydrographs . . . . . . . . . . . . . . . . . 101

Appendix 5. Results of chemical analysis for volatile organic compounds . . . . . 131 


\section{ILLUSTRATIONS}

\section{Plates [In Pocket]}

Plate 1. Lithostratigraphic cross-section along strike, Fischer and Porter Site and vicinity, Warminster, Pa.

2. Lithostratigraphic cross-section along dip, Fischer and Porter Site and vicinity, Warminster, $\mathrm{Pa}$.

3. Generalized stratigraphy, Fischer and Porter Site and vicinity, Warminster, Pa.

\section{Figures}

Page

Figure 1. Map showing location of the Fischer and Porter Site, Warminster, Pa. . .3

2. Map showing location of wells and boreholes at the Fischer and Porter Site and vicinity, Warminster, $\mathrm{Pa} . \ldots \ldots \ldots \ldots \ldots \ldots . \ldots \ldots$

3. Graph showing movement of a high-conductance fluid slug injected in borehole BK-2514 at 80 feet below land surface, Fischer and Porter Site, Warminster, Pa... . . . . . . . . . . . . . . . . . 8

4. Generalized sketch of straddle-packer assembly and sampling pump in a borehole. . . . . . . . . . . . . . . . . . . . 12

5. Caliper log from borehole BK-372 showing borehole-flow measurements, Fischer and Porter Site, Warminster, Pa., March 1, 1991................................18

6. Hydrograph of borehole MG-1241, Hatboro, Pa., May 21 to

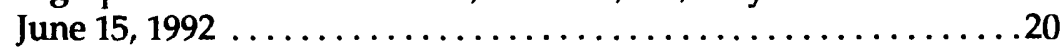

7. Caliper log from borehole MG-1241 showing borehole-flow measurements, Hatboro, Pa., September 9, $1992 \ldots \ldots \ldots \ldots \ldots .21$

8. Caliper log from borehole MG-1242 showing borehole-flow measurements, Hatboro, Pa., December 7, 1990 ...........22

9. Photograph from borehole television survey of borehole BK-2512 showing fracture at $\mathbf{2 4 8 . 2}$ feet below land surface, Fischer and Porter Site, Warminster, Pa.......................24

10. Caliper log from borehole BK-2512 showing borehole-flow measurements, Fischer and Porter Site, Warminster, Pa. . . . . . 25

11. Caliper log from borehole BK-2514 showing borehole-flow measurements, Fischer and Porter Site, Warminster, Pa. . . . . . 26

12. Water-level contour map for wells screened in the shallow zone, Fischer and Porter Site, Warminster, Pa., December 13, 1993. . . . . 40

13. Water-level contour map for wells screened in the shallow zone, Fischer and Porter Site, Warminster, Pa., May 3, 1994. . . . . . . . 41

14. Water-level contour map for wells screened in the intermediate zone,

Fischer and Porter Site, Warminster, Pa., December 13, 1993. . . . .43 


\section{ILLUSTRATIONS—Continued}

Figure 15. Water-level contour map for wells screened in the intermediate zone, Fischer and Porter Site, Warminster, Pa., May 3, 1994 . . . . .44

16. Water-level contour map for wells screened in the deep zone, Fischer and Porter Site, Warminster, Pa., December 13, 1993. . . . . 45

17. Water-level contour map for wells screened in the deep zone, Fischer and Porter Site, Warminster, Pa., May 3, 1994.

18. Map showing rise in water level in wells screened in the intermediate zone caused by the shutdown of the treatment system wells, Fischer and Porter Site, Warminster, Pa. . . . . . . . . . . 47

19. Map showing rise in water level in wells screened in the deep zone caused by the shutdown of the treatment system wells, Fischer and Porter Site, Warminster, Pa....................48

20. Sketch showing typical reaction pathways for the anaerobic degradation of tetrachloroethylene and trichloroethylene by reductive dehalogenation

\section{Appendix 1 Figures}

Figures 1-28. Borehole geophysical logs for borehole:

1. BK-372, Fischer and Porter Site, Warminster, Pa., March 1, 1991 . . .58

2. BK-372, Fischer and Porter Site, Warminster, Pa.,

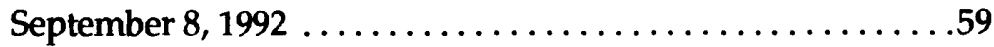

3. BK-1324, Fischer and Porter Site, Warminster, Pa............60

4. BK-1731, Fischer and Porter Site, Warminster, Pa., May 31, $1991 \ldots \ldots \ldots \ldots \ldots \ldots \ldots \ldots \ldots \ldots \ldots \ldots \ldots .6 \ldots \ldots$

5. BK-1731, Fischer and Porter Site, Warminster, Pa., September 14, $1992 \ldots \ldots \ldots \ldots \ldots \ldots \ldots \ldots \ldots \ldots \ldots 6 . \ldots \ldots$

6. BK-1795, Fischer and Porter Site, Warminster, Pa. ..........63

7. BK-1796, Fischer and Porter Site, Warminster, Pa., September 14, $1992 \ldots \ldots \ldots \ldots \ldots \ldots \ldots \ldots \ldots \ldots \ldots \ldots 64$

8. BK-1796, Fischer and Porter Site, Warminster, Pa., September 28, $1992 \ldots \ldots \ldots \ldots \ldots \ldots \ldots \ldots \ldots \ldots \ldots 6$

9. MG-1241, Hatboro, Pa., November 26 and December 7, $1990 \ldots \ldots \ldots \ldots \ldots \ldots \ldots \ldots \ldots \ldots \ldots 6 . \ldots \ldots 6 . \ldots \ldots$

10. MG-1241, Hatboro, Pa., September 9, $1992 \ldots \ldots \ldots \ldots \ldots \ldots .67$

11. MG-1242, Hatboro, Pa., December 7, 1990. .............68

12. MG-1242, Hatboro, Pa., September 9, 1992 . . . . . . . . . . . .69

13. BK-2511, Fischer and Porter Site, Warminster, Pa. .........70

14. BK-2512, Fischer and Porter Site, Warminster, Pa. . . . . . . . . 71

15. BK-2513, Fischer and Porter Site, Warminster, Pa...........72 


\section{ILLUSTRATIONS-Continued}

Figures 1-28. Borehole geophysical logs for borehole:-Continued

16. BK-2514, Fischer and Porter Site, Warminster, Pa...........73

17. BK-2515, Fischer and Porter Site, Warminster, Pa........... 74

18. BK-2516, Fischer and Porter Site, Warminster, Pa............75

19. BK-2517, Fischer and Porter Site, Warminster, Pa. . . . . . . . . 76

20. BK-2518, Fischer and Porter Site, Warminster, Pa. . . . . . . . . 77

21. BK-2521, Fischer and Porter Site, Warminster, Pa...........78

22. BK-2522, Fischer and Porter Site, Warminster, Pa. . . . . . . . . . 79

23. BK-2523, Fischer and Porter Site, Warminster, Pa...........80

24. BK-2524, Fischer and Porter Site, Warminster, Pa...........81

25. BK-2525, Fischer and Porter Site, Warminster, Pa...........82

26. BK-2526, Fischer and Porter Site, Warminster, Pa. . . . . . . . . 83

27. BK-2527, Fischer and Porter Site, Warminster, Pa............84

28. BK-2528, Fischer and Porter Site, Warminster, Pa. ..........85

\section{Appendix 4 Figures}

Figures 1-28. Hydrographs of wells:

1. BK-2511, Fischer and Porter Site, Warminster, Pa.,

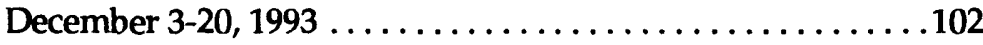

2. BK-2521, Fischer and Porter Site, Warminster, Pa.,

December 6-20, 1993 ...........................103

3. BK-2521, Fischer and Porter Site, Warminster, Pa.,

December 20, 1993, to January 14, $1994 \ldots \ldots \ldots \ldots \ldots \ldots 104$

4. BK-1731, Fischer and Porter Site, Warminster, Pa.,

December 3-20, $1993 \ldots \ldots \ldots \ldots \ldots \ldots \ldots \ldots \ldots \ldots \ldots . \ldots \ldots$

5. BK-1731, Fischer and Porter Site, Warminster, Pa.,

December 20, 1993, to January 13, $1994 \ldots \ldots \ldots \ldots \ldots \ldots . \ldots 6$

6. BK-2515, Fischer and Porter Site, Warminster, Pa.,

December 8-20, 1993 ...............................107

7. BK-2515, Fischer and Porter Site, Warminster, Pa.,

December 20, 1993, to January 13, $1994 \ldots \ldots \ldots \ldots \ldots \ldots 108$

8. BK-2527, Fischer and Porter Site, Warminster, Pa.,

December 7-20, 1993 ...........................109

9. BK-2527, Fischer and Porter Site, Warminster, Pa.,

December 20, 1993, to January 13, $1994 \ldots \ldots \ldots \ldots \ldots \ldots \ldots 110$

10. BK-2528, Fischer and Porter Site, Warminster, Pa.,

December 7-20, 1993 ............................ 111 


\section{ILLUSTRATIONS-Continued}

Figures 1-28. Hydrographs of wells:-Continued

11. BK-2528, Fischer and Porter Site, Warminster, Pa.,

December 20, 1993, to January 13, $1994 \ldots \ldots \ldots \ldots \ldots \ldots .112$

12. BK-1795, Fischer and Porter Site, Warminster, Pa.,

December 6-20, 1993 ........................113

13. BK-1795, Fischer and Porter Site, Warminster, Pa.,

December 20, 1993, to January 21, 1994 .

14. BK-1795, Fischer and Porter Site, Warminster, Pa., May 9-23, 1994 .115

15. BK-1796, Fischer and Porter Site, Warminster, Pa.,

December 8-20, 1993 . . . . . . . . . . . . . . . . . 116

16. BK-1796, Fischer and Porter Site, Warminster, Pa.,

December 20, 1993, to January 13, $1994 \ldots \ldots \ldots \ldots \ldots \ldots 117$

17. BK-2514, Fischer and Porter Site, Warminster, Pa.,

May 9-23, $1994 \ldots \ldots \ldots \ldots \ldots \ldots \ldots \ldots \ldots \ldots \ldots \ldots . \ldots \ldots$

18. BK-2526, Fischer and Porter Site, Warminster, Pa., April 12 to May 9, 1994 ........................ 119

19. BK-2526, Fischer and Porter Site, Warminster, Pa.,

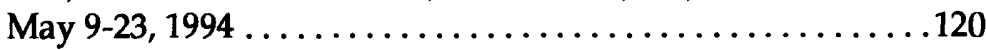

20. BK-1793, Fischer and Porter Site, Warminster, Pa.,

November 4 to December 6, 1993 ..................... 121

21. BK-2513, Fischer and Porter Site, Warminster, Pa.,

November 5 to December 6, 1993 .................. 122

22. BK-2524, Fischer and Porter Site, Warminster, Pa.,

November 8 to December $8,1993 \ldots \ldots \ldots \ldots \ldots \ldots \ldots . \ldots 123$

23. BK-2525, Fischer and Porter Site, Warminster, Pa.,

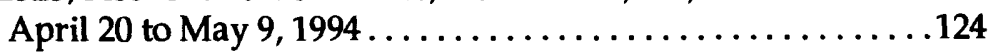

24. BK-2512, Fischer and Porter Site, Warminster, Pa.,

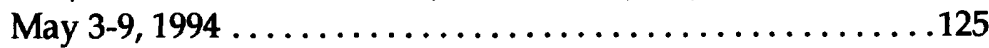

25. BK-2512, Fischer and Porter Site, Warminster, Pa.,

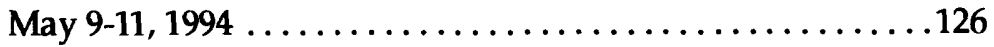

26. BK-2512, Fischer and Porter Site, Warminster, Pa.,

May 16-19, $1994 \ldots \ldots \ldots \ldots \ldots \ldots \ldots \ldots \ldots \ldots \ldots \ldots \ldots$

27. BK-2522, Fischer and Porter Site, Warminster, Pa.,

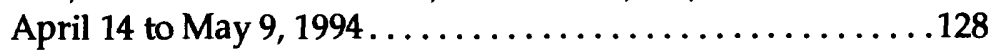

28. BK-2523, Fischer and Porter Site, Warminster, Pa.,

April 11 to May $9,1994 \ldots \ldots \ldots \ldots \ldots \ldots \ldots \ldots \ldots \ldots \ldots . \ldots \ldots$ 


\section{TABLES}

Table 1. Record of wells and boreholes, Fischer and Porter Site,

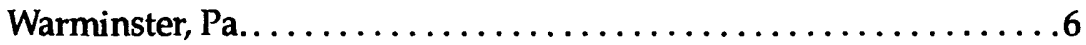

2. Intervals secreened in monitor wells, Fischer and Porter Site, Warminster, Pa............................... 10

3. Intervals isolated by straddle packers in borehole BK-2511, Fischer and Porter Site, Warminster, Pa.. . . . . . . . . . . . . . . . 28

4. Water levels before and at the end of aquifer-isolation tests of borehole BK-2511, Fischer and Porter Site, Warminster, Pa. . . . . . 28

5. Intervals isolated by straddle packers in borehole BK-2512, Fischer and Porter Site, Warminster, Pa....................... 29

6. Water levels before and at the end of aquifer-isolation tests of borehole BK-2512, Fischer and Porter Site, Warminster, Pa....... 29

7. Intervals isolated by straddle packers in borehole BK-2513, Fischer and Porter Site, Warminster, Pa..................... 30

8. Water levels before and at the end of aquifer-isolation tests of borehole BK-2513, Fischer and Porter Site, Warminster, Pa. . . . . . . 30

9. Intervals isolated by straddle packers in borehole BK-2514, Fischer and Porter Site, Warminster, Pa.......................

10. Water levels before and at the end of aquifer-isolation tests of borehole BK-2514, Fischer and Porter Site, Warminster, Pa. . . . . . 32

11. Intervals isolated by straddle packers in borehole BK-2515, Fischer and Porter Site, Warminster, Pa....................... 32

12. Water levels before and at the end of aquifer-isolation tests of borehole BK-2515, Fischer and Porter Site, Warminster, Pa. . . . . . 33

13. Intervals isolated by straddle packers in borehole MG-1242,

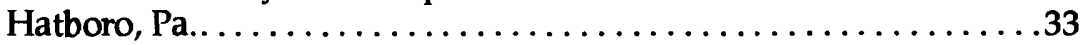

14. Water levels before and at the end of aquifer-isolation tests of borehole MG-1242, Hatboro, Pa.....................34

15. Changes in water level caused by pumping of public-supply wells and the shutdown of the Fischer and Porter treatment system wells, Fischer and Porter Site, Warminster, Pa. ................... 35

16. Water-level measurements, December 13, 1993, and May 3, 1994, Fischer and Porter Site, Warminster, Pa.................. 36

17. Volatile organic compounds detected in water samples from borehole BK-2511, Fischer and Porter Site, Warminster, Pa....... 50

18. Volatile organic compounds detected in water samples from borehole BK-2512, Fischer and Porter Site, Warminster, Pa....... 50

19. Volatile organic compounds detected in water samples from borehole BK-2513, Fischer and Porter Site, Warminster, Pa. .......51 


\section{TABLES-Continued}

Table 20. Volatile organic compounds detected in water samples from borehole BK-2514, Fischer and Porter Site, Warminster, Pa........51

21. Volatile organic compounds detected in water samples from borehole BK-2515, Fischer and Porter Site, Warminster, Pa........51

\section{Appendix 2 Tables}

Tables 1-3. Geologic log of rock core from coreholes:

1. BK-2516, Fischer and Porter Site, Warminster, Pa. . . . . . . . 88

2. BK-2517, Fischer and Porter Site, Warminster, Pa. . . . . . . . 90

3. BK-2518, Fischer and Porter Site, Warminster, Pa..........92

\section{Appendix 3 Tables}

Tables 1-5. Geologic log for boreholes:

1. BK-2511, Fischer and Porter Site, Warminister, Pa...........96

2. BK-2512, Fischer and Porter Site, Warminster, Pa........... 97

3. BK-2513, Fischer and Porter Site, Warminster, Pa. . . . . . . . . . . 98

4. BK-2514, Fischer and Porter Site, Warminster, Pa............99

5. BK-2515, Fischer and Porter Site, Warminster, Pa..........100

\section{Appendix 5 Tables}

Tables 1-6. Results of chemical analyses for volatile organic compounds in water samples from boreholes:

1. BK-2511, Fischer and Porter Site, Warminster, Pa. ..........132

2. BK-2512, Fischer and Porter Site, Warminster, Pa..........133

3. BK-2513, Fischer and Porter Site, Warminster, Pa. . ......... 134

4. BK-2514, Fischer and Porter Site, Warminster, Pa..........135

5. BK-2515, Fischer and Porter Site, Warminster, Pa..........136

6. MG-1242, Hatboro, Pa. .....................137 


\section{CONVERSION FACTORS AND ABBREVIATIONS}

Multiply

inch (in.)

foot (ft)

mile (mi)

foot per minute ( $\mathrm{ft} / \mathrm{min})$

foot per day (ft/d)

acre

gallon (gal)

gallon per minute (gal/min)

gallon per minute per foot

[(gal/min)/ft]

degree Fahrenheit $\left({ }^{\circ} \mathrm{F}\right)$
By

Io obtain

Length

25.4

0.3048

1.609

0.3048

0.3048

Area

0.4047

Volume

3.785

Elow

0.06309

\section{Specific Capacity}

0.2070

liter per second per meter

\section{Iemperature}

${ }^{\circ} \mathrm{C}=5 / 9\left({ }^{\circ} \mathrm{F}-32\right)$ hectare

liter

liter per second

millimeter

meter

kilometer

meter per minute

meter per day degree Celsius

Sea level: In this report, "sea level" refers to the National Geodetic Vertical Datum of 1929 - a geodetic datum derived from a general adjustment of the first-order level nets of the United States and Canada, called Sea Level of 1929.

Abbreviated water-quality units used in report:

$(\mu \mathrm{g} / \mathrm{L})$ micrograms per liter

$(\mu \mathrm{S} / \mathrm{cm})$ microsiemens per centimeter at 25 degrees Celsius 


\title{
GEOHYDROLOGY \\ AND VERTICAL DISTRIBUTION \\ OF VOLATILE ORGANIC COMPOUNDS \\ IN GROUND WATER, \\ FISCHER AND PORTER COMPANY SUPERFUND SITE, WARMINSTER, BUCKS COUNTY, PENNSYLVANIA
}

\author{
By Ronald A. Sloto, Paola Macchiaroli, and Randall W. Conger
}

\begin{abstract}
The Fischer and Porter Company Superfund Site is underlain by sedimentary rocks of the Upper Triassic Stockton Formation, which consists of interbedded siltstone, very-fine grained to coarse-grained sandstone, and conglomerate in crudely defined, upward fining cycles. These rocks form a complex, heterogeneous, leaky, multiaquifer system comprised of a series of gently dipping lithologic units with different hydraulic properties. Ground water is unconfined in the shallower part of the aquifer and confined or semiconfined in the deeper part of the aquifer. Water levels measured in monitor well clusters and borehole-flow measurements made in open boreholes show a downward hydraulic head gradient at the site, caused in part by the pumping of nearby, deep public-supply wells and the Fischer and Porter treatment system extraction wells. Downward borehole flow was measured at rates up to 9 gallons per minute. Aquifer-isolation tests were run in the six boreholes to obtain depth-discrete specific-capacity and water-quality data. On the basis of specific-capacity data for 27 isolated intervals, specific capacity is not related to depth.

Water levels in monitor wells at the Fischer and Porter Site are greatly affected by the pumping of nearby public-supply wells, as well as the pumping of the Fischer and Porter treatment system extraction wells. Pumping of the public-supply wells causes daily water-level fluctuations in wells at the site as great as 5.3 feet. The shutdown of the Fischer and Porter treatment system extraction wells caused a rise in water level in all wells screened in the intermediate and deep zones. The rise in water level was as great as 4.3 feet in the intermediate zone and as great as 5.9 feet in the deep zone. The direction of ground-water flow is toward the north in the shallow and intermediate zones and toward the west and west-southwest in the deep zone. Ground-water discharge probably is to the unnamed tributary to Pennypack Creek north and west of the site.

Volatile organic compounds (VOC's) were detected in most depth-discrete water samples. No general trend of increasing or decreasing concentrations of VOC's with depth were observed, and none of the isolated intervals had highly elevated concentrations of VOC's. Observed fairly constant concentrations of VOC's with depth are the result of the downward head gradient and the former presence of open boreholes on the site. The downward head gradient and pumping of nearby, deep public-supply wells caused the vertical migration and outward movement of VOC's into the aquifer through former supply and monitor wells of open-hole construction in the main area of contamination.
\end{abstract}




\section{INTRODUCTION}

The Fischer and Porter Company Superfund Site (fig. 1) occupies about 41 acres in Warminster Township, Bucks County, Pa., on the boundary between Bucks and Montgomery Counties. In 1979, volatile organic compounds (VOC's) were detected in nearby public-supply wells. VOC's also were detected in Fischer and Porter's onsite supply wells. A suit filed by the U.S. Environmental Protection Agency (USEPA) against the Fischer and Porter Company in October of 1980 was settled in November of 1984. Under the Consent Decree, the Fischer and Porter Company pumps and treats ground water from three onsite wells at a combined rate of $75 \mathrm{gal} / \mathrm{min}$. The Fischer and Porter Site was designated as a Superfund site and placed on the National Priorities List in September of 1983 under the USEPA's Comprehensive Environmental Response, Compensation, and Liability Act program (U.S. Environmental Protection Agency, 1992). A remedial investigation/feasibility study was never done for the site.

This investigation by the USGS was done to (1) provide hydrologic and geologic data for the site, (2) determine the vertical and horizontal extent of ground-water contamination by VOC's along the site boundary, and (3) determine the hydraulic effect of pumping the wells in the Fischer and Porter treatment system. The report will serve as the hydrology and geology background of the USEPA's evaluation of the effectiveness of the Fischer and Porter treatment system.

The investigation was done in six phases: (1) borehole geophysical logging of existing boreholes, (2) drilling exploratory boreholes and coreholes, (3) geophysical logging and borehole television surveys of exploratory boreholes, (4) packer testing and ground-water sampling of exploratory boreholes, (5) construction of exploratory boreholes as monitor wells and drilling and construction of additional monitor wells, and (6) water-level monitoring.

In this report, the term "borehole" is used to describe open-hole construction drilled holes used for the collection of geologic, hydrologic, water-level, and (or) water-quality data. The term "well" is used to describe drilled holes that have been completed as screened monitor wells, public-supply wells, and pumped extraction wells in the Fischer and Porter treatment system.

\section{Purpose and Scope}

This report details the hydrogeology of the Fischer and Porter Site. The report describes (1) the geologic framework of the site, (2) vertical and horizontal ground-waterflow directions, (3) the vertical distribution of specific capacity in zones isolated by straddle packers, (4) the response of water levels to pumping stress, and (5) the vertical and horizontal extent of ground-water contamination by VOC's at the site boundaries. The report presents all data collected during the investigation.

\section{Physiography and Climate}

The Fischer and Porter Site is underlain by sedimentary rocks of the Triassic Lowlands Section of the Piedmont Physiographic Province. The local topography is flat to rolling. The area surrounding the Fischer and Porter Site is drained by tributaries to Pennypack Creek (fig. 1), which flows southward to the Delaware River.

The area has a humid, modified continental climate characterized by warm summers and moderately cold winters. The normal (1961-90) mean annual temperature at the Neshaminy Falls National Oceanic and Atmospheric Administration station, which is 7 $\mathrm{mi}$ to the southeast, is $53.3^{\circ} \mathrm{F}$ (Owenby and Ezell, 1992). The normal (1961-90) mean temperature for January, the coldest month, is $29.6^{\circ} \mathrm{F}$, and the normal mean temperature for July, the warmest month, is $75.4^{\circ} \mathrm{F}$. 


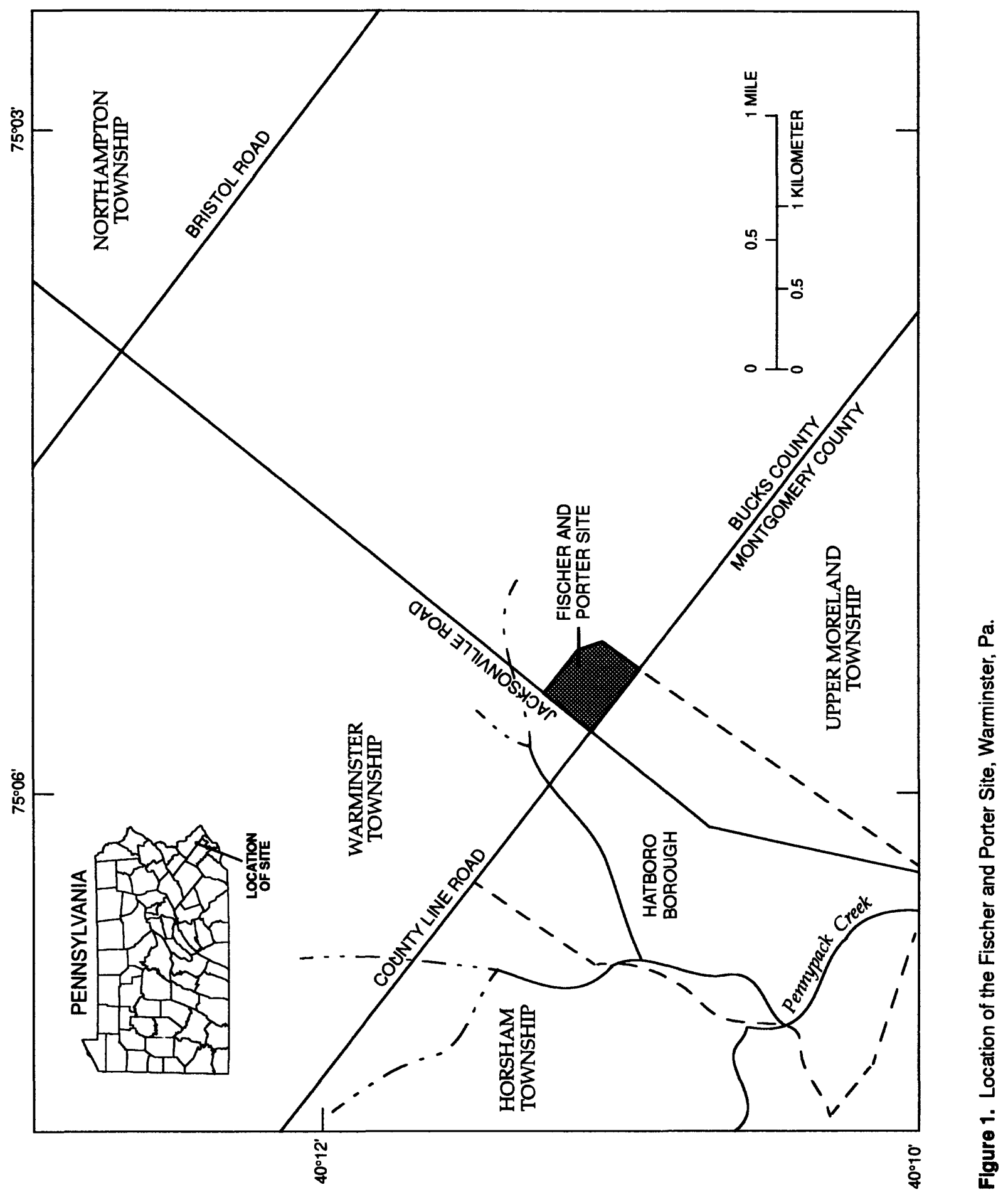


The normal (1961-90) annual precipitation at the Neshaminy Falls station is 45.43 in. Precipitation is about evenly distributed throughout the year, with slightly more occurring during July and August because of localized thunderstorms.

\section{Previous Ground-Water Investigations}

The geology and hydrology of the Stockton Formation in southeastern Pennsylvania was described by Rima and others (1962). Sloto and Davis (1983) described the effect of urbanization on the water resources of Warminster Township. Sloto and others (1992, 1994) and Sloto (1995) described the use of borehole geophysical methods to determine the extent of aquifer cross-contamination by VOC's through open boreholes in Hatboro, Pa. Two site studies (SMC-Martin, Inc., 1980; BCM, Inc., 1986) were done for the Fischer and Porter Company by consulting firms.

\section{Acknowledgments}

The authors thank the Fischer and Porter Company for their cooperation, access to existing wells, and permission to drill and test additional wells on their property; William Gross was especially helpful. The authors also thank the Hatboro Water Authority for data, access to their wells, and for pumping well MG-946; Robert Todd and Joseph Gallagher were especially helpful.

\section{METHODS OF STUDY}

\section{Borehole Geophysical Logs}

Caliper, natural-gamma, single-point-resistance, fluid-resistivity, and fluidtemperature logs were run in 5 existing boreholes onsite, 2 existing boreholes offsite, and 13 boreholes and 3 coreholes drilled for this investigation (fig. 2). Data for wells and boreholes are given in table 1.

\section{Caliper Logs}

Caliper logs provide a continuous record of average borehole diameter, which is related to fractures, lithology, and drilling technique. The caliper tool is calibrated at land surface after each log is run. Caliper logs were used to help correlate lithostratigraphy, identify fractures and possible water-bearing openings, and qualitatively correct other geophysical logs for changes in borehole diameter. Correlation of caliper logs with singlepoint-resistance, fluid-resistance, and fluid-temperature logs was used to identify fractures and water-producing and water-receiving openings.

\section{Natural-Gamma Logs}

Natural-gamma logs, also called gamma-ray logs, record the natural-gamma radiation emitted from rocks penetrated by the borehole. Gamma radiation can be measured through casing, but the gamma response is dampened. Uranium-238, thorium232 , and the progeny of their decay series and potassium- 40 are the most common emitters of natural-gamma radiation. These radioactive elements may be concentrated in clay by adsorption and ion exchange; therefore, fine-grained sedimentary rocks (siltstone units) usually emit more gamma radiation than do coarse-grained sedimentary rocks (sandstone units). Natural-gamma logs were used to differentiate between sandstone and siltstone units and to correlate lithostratigraphy between boreholes. 


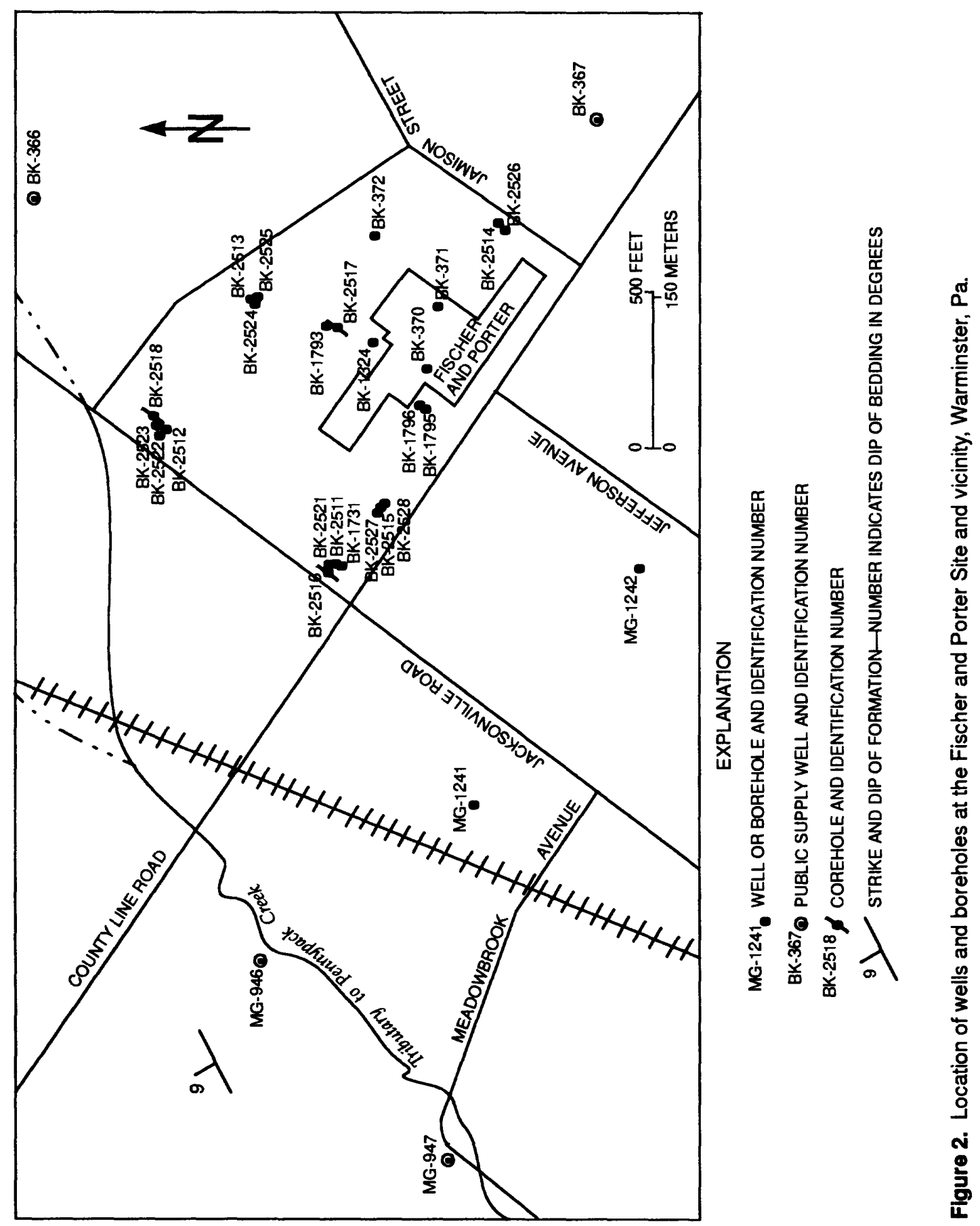


Table 1. Record of wells and boreholes, Fischer and Porter Site, Warminster, Pa.

[USGS, U.S. Geological Survey; OH, open-hole construction; S, PVC screen; TOC, top of casing;

$M$, monitor well; $P$, active public-supply well; $T$, Fischer and Porter treatment system extraction well;

$X$, destroyed; $U$, unused public- supply well; --, no data]

\begin{tabular}{|c|c|c|c|c|c|c|c|c|}
\hline $\begin{array}{l}\text { USGS } \\
\text { identi- } \\
\text { fication } \\
\text { number }\end{array}$ & Owner and owner identification number & $\begin{array}{c}\text { Year } \\
\text { drilled }\end{array}$ & $\begin{array}{l}\text { Depth } \\
\text { drilled } \\
\text { (feet) }\end{array}$ & $\begin{array}{l}\text { Casing } \\
\text { length } \\
\text { (feet) }\end{array}$ & $\begin{array}{l}\text { Casing } \\
\text { diameter } \\
\text { (inches) }\end{array}$ & $\begin{array}{l}\text { Open interval } \\
\text { (feet below } \\
\text { land surface) }\end{array}$ & $\begin{array}{c}\text { Elevation of } \\
\text { land surface } \\
\text { (feet above } \\
\text { sea level) }\end{array}$ & $\begin{array}{c}\text { Use of } \\
\text { well }\end{array}$ \\
\hline BK-366 & Warminster Heights Development Corporation WH-1 & - & 300 & 40 & 8 & $40-300 \mathrm{OH}$ & 280 & $P$ \\
\hline BK-367 & Warminster Heights Development Corporation WH-2 & 1943 & 300 & 56 & 8 & $56-300 \mathrm{OH}$ & 300 & $P$ \\
\hline BK-370 & Fischer and Porter Company FP-2 & 1940 & 190 & 15 & 6 & $15-190 \mathrm{OH}$ & 296.79 TOC & $\mathbf{T}$ \\
\hline BK-371 & Fischer and Porter Company FP-1 & 1948 & 474 & - & 8 & - & $305.39 \mathrm{TOC}$ & $\mathrm{T}$ \\
\hline BK-372 & Fischer and Porter Company FP-3 & 1952 & 601 & 49.5 & 8 & - & 309.48 & $\mathbf{x}$ \\
\hline BK-1324 & Fischer and Porter Company FP-7 & 1980 & 300 & 19 & 6 & $21.4-300 \mathrm{OH}$ & 300.73 & $\mathrm{~T}$ \\
\hline BK-1731 & U.S. Environmental Protection Agency & 1991 & 300 & 47 & 6 & $47-65 \mathrm{OH}$ & 282.71 & $\mathbf{M}$ \\
\hline BK-1793 & Fischer and Porter Company FP-5 & 1980 & 40 & 23.4 & 6 & $23.4-40 \mathrm{OH}$ & 295.06 & M \\
\hline BK-1795 & Fischer and Porter Company FP-8 & 1980 & 54 & 23 & 6 & $23-31 \mathrm{OH}$ & 302.52 & M \\
\hline BK-1796 & Fischer and Porter Company FP-12 & 1985 & 146 & 78 & 6 & $78-146 \mathrm{OH}$ & 302.82 & M \\
\hline BK-2511 & U.S. Environmental Protection Agency & 1993 & 352 & 146 & $\begin{array}{l}8 \text { steel } \\
4 \text { PVC }\end{array}$ & $300-325 \mathrm{~S}$ & 281.38 & M \\
\hline BK-2512 & U.S. Environmental Protection Agency & 1993 & 303 & $\begin{array}{r}5 \\
87\end{array}$ & $\begin{array}{l}12 \text { steel } \\
8 \text { steel } \\
4 \text { PVC }\end{array}$ & $237-257 \mathrm{~S}$ & 271.16 & M \\
\hline BK-2513 & U.S. Environmental Protection Agency & 1993 & 301 & $\begin{array}{r}5 \\
126\end{array}$ & $\begin{array}{l}12 \text { steel } \\
8 \text { steel } \\
4 \text { PVC }\end{array}$ & $255-275 \mathrm{~S}$ & 285.37 & $\mathbf{M}$ \\
\hline BK-2514 & U.S. Environmental Protection Agency & 1993 & 292 & 37 & $\begin{array}{l}8 \text { steel } \\
4 \text { PVC }\end{array}$ & $217-252 \mathrm{~S}$ & 314.67 & M \\
\hline BK-2515 & U.S. Environmental Protection Agency & 1993 & 310 & 108 & $\begin{array}{l}8 \text { steel } \\
4 \text { PVC }\end{array}$ & $285-305 \mathrm{~S}$ & 291.50 & $\mathbf{M}$ \\
\hline BK-2516 & U.S. Environmental Protection Agency & 1993 & 262 & 15 & 4 & - & 281.98 & $\mathrm{X}$ \\
\hline BK-2517 & U.S. Environmental Protection Agency & 1993 & 277 & 20 & 4 & - & 295.48 & $\mathrm{x}$ \\
\hline BK-2518 & U.S. Environmental Protection Agency & 1993 & 274.5 & 10 & 4 & - & 271.36 & $\mathbf{x}$ \\
\hline BK-2521 & U.S. Environmental Protection Agency & 1993 & 229 & 63 & $\begin{array}{l}8 \text { steel } \\
4 \text { PVC }\end{array}$ & $190-210 \mathrm{~S}$ & 281.99 & $\mathbf{M}$ \\
\hline BK-2522 & U.S. Environmental Protection Agency & 1993 & 159 & 21 & $\begin{array}{l}8 \text { steel } \\
4 \text { PVC }\end{array}$ & $132-157 \mathrm{~S}$ & 271.62 & M \\
\hline BK-2523 & U.S. Environmental Protection Agency & 1993 & 53 & 21 & $\begin{array}{l}8 \text { steel } \\
4 \text { PVC }\end{array}$ & $23.5-43.5 \mathrm{~S}$ & 271.21 & $\mathbf{M}$ \\
\hline BK-2524 & U.S. Environmental Protection Agency & 1993 & 158 & 30 & $\begin{array}{l}8 \text { steel } \\
4 \text { PVC }\end{array}$ & $115-135 \mathrm{~S}$ & 285.13 & $\mathbf{M}$ \\
\hline BK-2525 & U.S. Environmental Protection Agency & 1993 & 80 & $\begin{array}{l}10 \\
30\end{array}$ & $\begin{array}{l}12 \text { steel } \\
8 \text { steel } \\
4 \text { PVC }\end{array}$ & $31-51 \mathrm{~S}$ & 285.41 & $\mathbf{M}$ \\
\hline BK-2526 & U.S. Environmental Protection Agency & 1993 & 79 & 21 & $\begin{array}{l}8 \text { steel } \\
4 \text { PVC }\end{array}$ & $50-70 \mathrm{~s}$ & 315.40 & M \\
\hline BK-2527 & U.S. Environmental Protection Agency & 1993 & 201 & 21 & $\begin{array}{l}8 \text { steel } \\
4 \text { PVC }\end{array}$ & $157-187 \mathrm{~S}$ & 292.26 & $\mathbf{M}$ \\
\hline BK-2528 & U.S. Environmental Protection Agency & 1993 & 53.5 & 21 & $\begin{array}{l}8 \text { steel } \\
4 \text { PVC }\end{array}$ & $25-45 \mathrm{~S}$ & 292.92 & M \\
\hline MG-946 & Hatboro Borough Authority H-16 & 1969 & 300 & $\begin{array}{l}30 \\
40\end{array}$ & $\begin{array}{l}14 \\
10\end{array}$ & $40-300 \mathrm{OH}$ & 240 & $\mathbf{U}$ \\
\hline MG-947 & Hatboro Borough Authority H-17 & 1969 & 300 & $\begin{array}{l}31 \\
42\end{array}$ & $\begin{array}{l}14 \\
10\end{array}$ & $42-300 \mathrm{OH}$ & 245 & $\mathbf{P}$ \\
\hline MG-1241 & Fischer and Porter Company FP-13 & - & 174 & 21 & 6 & $21-70.5 \mathrm{OH}$ & 270 & $\mathbf{M}$ \\
\hline MG-1242 & Fischer and Porter Company FP-14 & - & 177 & 19 & 6 & 19-135 OH & 302 & $\mathbf{M}$ \\
\hline
\end{tabular}




\section{Single-Point-Resistance Logs}

Single-point-resistance logs record the electrical resistance between the borehole and an electrical ground at land surface. In general, resistance increases with grain size and decreases with borehole diameter, density of water-bearing openings, and increasing dissolved-solids concentration of borehole fluid (Keys, 1990). A fluid-filled borehole is required for single-point-resistance logs, and they are run only for the saturated part of the formation below the casing. Single-point-resistance logs were used to correlate lithostratigraphy and sometimes helped to identify the location of water-bearing openings because a fluid-filled fracture is less resistive than solid rock.

\section{Fluid-Resistivity Logs}

Fluid-resistivity logs measure the electrical resistance of fluid in the borehole. Resistivity is the reciprocal of fluid conductivity, and fluid-resistivity logs reflect changes in the dissolved-solids concentration of the borehole fluid. Fluid-resistivity logs were used to identify water-producing and water-receiving openings and to determine intervals of vertical-borehole flow. Water-producing and water-receiving openings usually were identified by sharp changes in resistivity, and intervals of borehole flow were identified by a low resistivity gradient between water-producing and water-receiving openings.

\section{Fluid-Temperature Logs}

Fluid-temperature logs provide a continuous record of the temperature of the fluid in the borehole. Fluid-temperature logs were used to identify water-producing and waterreceiving openings and to determine intervals of vertical borehole flow. Water-producing and water-receiving openings usually were identified by sharp changes in temperature, and intervals of vertical borehole flow were identified by little or no temperature gradient. In the study area, fluid-temperature logs from boreholes with no flow generally show a decrease in fluid temperature with depth caused by surface heating in the upper part of the borehole and an increase in fluid temperature with depth as a function of the geothermal gradient in the lower part of the borehole.

\section{Measurement of Borehole Flow}

Upon completion of geophysical logging, the suite of logs was evaluated in the field to choose zones of potential borehole flow. The direction and rate of borehole-fluid movement was determined by injecting a slug of high-conductance fluid at a specific depth in a borehole and monitoring the movement of the slug with the fluid-resistivity tool. This is the brine-tracing method described by Patten and Bennett (1962). The lower limit of flow measurement is about $0.5 \mathrm{gal} / \mathrm{min}$ in a 6-in. diameter borehole. Borehole flow was calculated by

$$
Q=7.481 \vee \pi r^{2},
$$

where $Q$ is borehole flow, in gallons per minute;

$V$ is the rate of vertical borehole-fluid movement, in feet per minute; and $r$ is the borehole radius, in feet.

Figure 3 shows the movement of a slug of high-conductance fluid injected $80 \mathrm{ft}$ below land surface (bls) in borehole BK-2514. The slug moved downward at $3.2 \mathrm{ft} / \mathrm{min}$, which is equal to a flow rate of $8.3 \mathrm{gal} / \mathrm{min}$ in an 8 -in. diameter borehole. 


\section{Borehole Television Surveys}

Borehole television surveys were conducted by lowering a waterproof video camera with a very wide angle lens down the borehole and recording the results on videotape. Borehole television surveys were used to aid interpretation of geophysical logs and to locate smooth sections of borehole to set straddle packers for the aquifer-isolation tests.

\section{Location of Deep Exploratory Boreholes and Coreholes}

Exploratory boreholes generally were drilled between public-supply wells and the main area of contamination (in the vicinity of well BK-1324). Ground water in the Stockton Formation moves preferentially in response to the pumping of wells. Corehole locations were chosen to provide geological data to aid understanding of the aquifersystem framework.

Borehole BK-2511 was drilled between the main area of contamination and Hatboro public-supply well MG-946 (H-16). Borehole BK-2512 was drilled downdip of the main area of contamination. Borehole BK-2513 was drilled between the main area of contamination and Warminster Heights Development Corporation public-supply well BK-366 (WH-1). Borehole BK-2514 was drilled between the main area of contamination

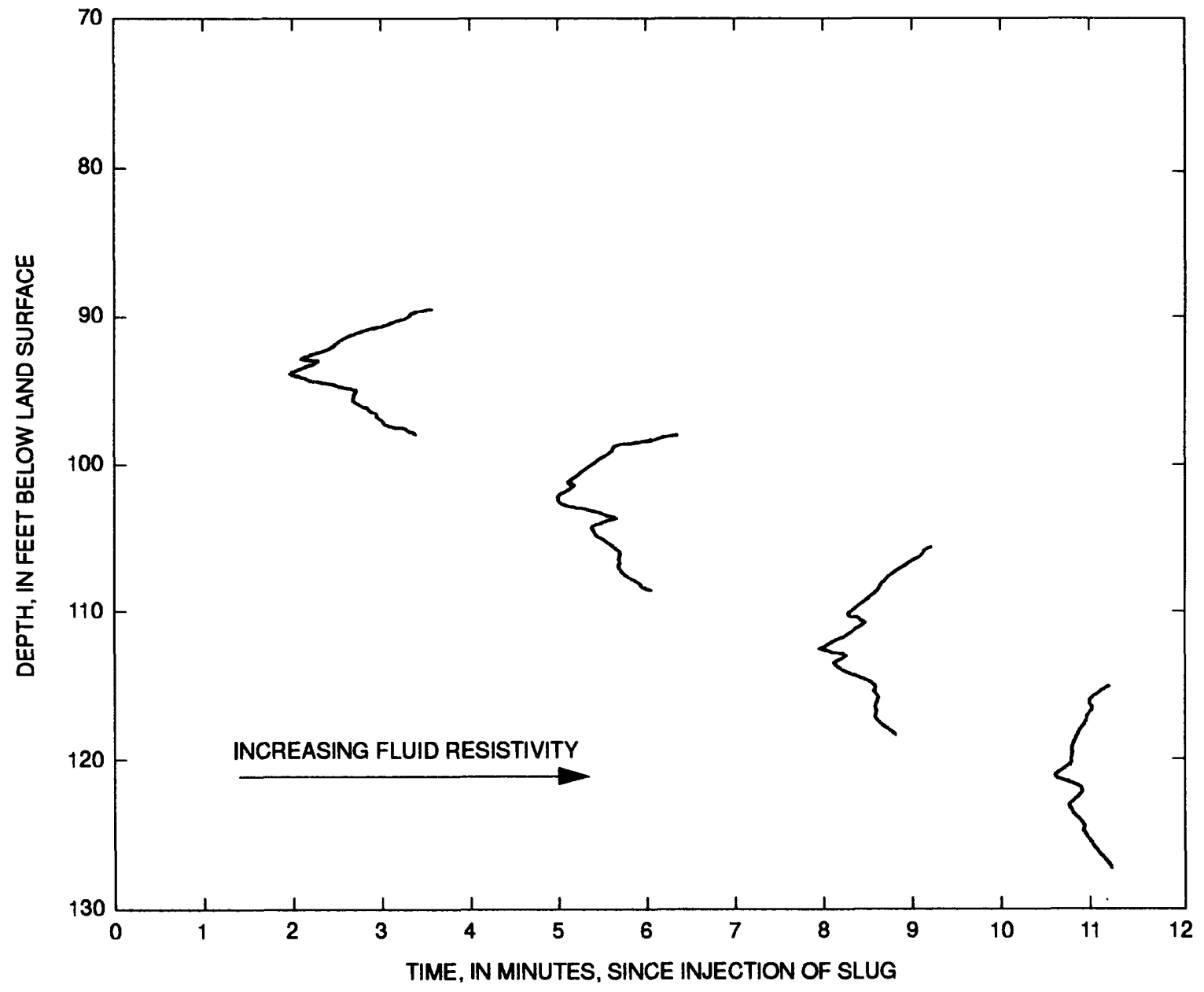

Flgure 3. Movement of a high-conductance fluid slug injected in borehole BK-2514 at 80 feet below land surface, Fischer and Porter Site, Warminster, $\mathrm{Pa}$. 
and Warminster Heights Development Corporation public-supply well BK-367 (WH-2). Borehole BK-2515 was drilled between the main area of contamination and Hatboro public-supply well MG-947 (H-17).

Three continuous rock cores were collected at the Fischer and Porter Site. Corehole BK-2517 was located in the main contaminant area to provide a continuous record of site geology at that location. Corehole BK-2518 was located downdip from the main contaminant area. Corehole BK-2516 was located along strike from the main contaminant area. The cores provide a continuous record of site geology and reference points to correlate geophysical logs to lithology. Geologic descriptions of the cores are given in appendix 2.

\section{Monitor Well Drilling and Construction}

Thirteen 8-in. diameter boreholes were drilled for this investigation by use of an air rotary drilling rig. Five deep exploratory boreholes (BK-2511, BK-2512, BK-2513, BK-2514, and BK-2515) were initially drilled (fig. 2). After geophysical logging and aquifer-isolation tests were completed in these boreholes, four intermediate-depth boreholes (BK-2521, BK-2522, BK-2524, and BK-2527) and four shallow boreholes (BK-2523, BK-2525, BK-2526, and BK-2528) were drilled near the deep boreholes in a cluster arrangement to screen the aquifer at different depths at the same location (fig. 2).

Boreholes were cased with 8-in. diameter steel casing set into competent bedrock. Boreholes BK-2512, BK-2513, and BK-2525 required an outer 12-in. diameter steel casing to prevent hole collapse while setting 8-in. diameter casing. A small quantity of potable water was added during drilling to prevent mudcaking if formation water production was insufficient. The quantity of water produced from each water-bearing zone during drilling was estimated. Water was blown from the borehole by use of compressed air, and the yield was measured by stopwatch and bucket after completion of drilling. Each borehole was developed by pumping with air pressure from the drilling rig for at least 30 minutes following completion of drilling. During drilling of the exploratory boreholes, composite samples of drill cuttings were collected for each 5 -ft interval. Geologic logs for the exploratory boreholes are given in appendix 3 .

Each borehole was constructed as a screened monitor well in the following manner. An interval to be screened was selected on the basis of drilling data, borehole geophysical logs, borehole television surveys, and aquifer-isolation test hydraulic and chemical data. Screened intervals for each borehole and the reasons why the intervals were chosen are listed in table 2 . The borehole was backfilled with bentonite to the bottom of the interval selected for screening. One to $2 \mathrm{ft}$ of coarse sand was placed on top of the bentonite, and a 4-in. diameter Schedule 40 polyvinyl chloride (PVC) flush joint threaded 0.020-in. well screen with an end cap on the lower end and a 4-in. diameter Schedule 40 PVC flush joint threaded inner casing was installed in the center of each borehole. A filter pack consisting of coarse sand was placed from the top of the bentonite backfill to $2 \mathrm{ft}$ above the top of the well screen in the annulus between the 8-in. diameter borehole and the 4-in. diameter PVC well screen. A bentonite seal was installed above the filter pack in the annulus, and the annulus was grouted to land surface with a 90-percent cement grout and 10-percent bentonite mixture pumped down the annulus with a tremie pipe.

Boreholes BK-1731, BK-1793, BK-1795, and BK-1796 were not reconstructed as monitor wells. The bottom of borehole BK-1731 was sealed with a 5 -ft thick bentonite plug to prevent downward leakage, making it a 65 -ft deep borehole of open-hole construction. Boreholes MG-1241 and MG-1242 were backfilled with bentonite on the basis of borehole geophysical logs and borehole television surveys to eliminate borehole flow and the cross-connection between water-bearing zones. Borehole MG-1241 was backfilled to 70.5 $\mathrm{ft}$ bls, and borehole MG-1242 was backfilled to $135 \mathrm{ft}$ bls. 
After completion of well construction, the elevation of the top of casing and (or) land surface of all wells installed by the USGS was surveyed. Elevations listed in table 1 are relative to the elevation of the top of casing of borehole BK-1793. The elevation for borehole BK-1793 was taken from table 29 of SMC-Martin, Inc. (1980). The SMC-Martin, Inc. report does not explain what datum was used as the basis for determining elevations. However, by using borehole BK-1793 as a reference point, water-level elevations measured for this study are comparable to those in SMC-Martin, Inc. (1980) and BCM, Inc. (1986).

The three coreholes were drilled by a hydraulic rotary drilling rig equipped with a wireline corebarrel retrieval system. Core was obtained in 10-ft lengths. The orientation was marked on the core, the recovery rate was noted, and the core was placed in marked boxes. After geophysical logging of the coreholes, the casings were removed, and the coreholes were abandoned by filling them with a 90 -percent cement grout and 10 -percent bentonite mixture to land surface.

Table 2. Intervals screened in monitor wells, Fischer and Porter Site, Warminster, Pa.

[USGS, U.S. Geological Survey, <, greater than; >, less than; gal/min, gallons per minute; $(\mathrm{gal} / \mathrm{min}) / \mathrm{ft}$, gallons per minute per foot; $\mathrm{ft} \mathrm{bls,} \mathrm{feet} \mathrm{below} \mathrm{land} \mathrm{surface]}$

\begin{tabular}{|c|c|c|c|c|}
\hline $\begin{array}{l}\text { USGS } \\
\text { well } \\
\text { number }\end{array}$ & $\begin{array}{l}\text { Depth } \\
\text { drilled }\end{array}$ & $\begin{array}{l}\text { Well } \\
\text { yield }\end{array}$ & $\begin{array}{l}\text { Screened } \\
\text { interval }\end{array}$ & Reason for selection of screened interval \\
\hline BK-2511 & 352 & 15 & $300-325$ & Deep $5 \mathrm{gal} / \mathrm{min}$ water-bearing zone \\
\hline BK-2512 & 303 & $>150$ & $237-257$ & $\begin{array}{l}\text { Deep water-bearing zone with yield }>70 \mathrm{gal} / \mathrm{min} \text { and specific capacity of } \\
8.7 \text { (gal/min)/ft. The geophysical logs and borehole-flow } \\
\text { measurements indicate that this zone is a water-receiving zone. }\end{array}$ \\
\hline BK-2513 & 301 & 100 & 255-275 & Deep $20 \mathrm{gal} / \mathrm{min}$ water-bearing zone \\
\hline BK-2514 & 292 & 35 & $217-252$ & $\begin{array}{l}\text { Deep } 30 \mathrm{gal} / \mathrm{min} \text { water-bearing zone. Geophysical logs and borehole- } \\
\text { flow measurements indicated that the fractures at } 225 \text { and } 250 \mathrm{ft} \text { bls are } \\
\text { water-receiving zones. }\end{array}$ \\
\hline BK-2515 & 310 & 15 & 285-305 & Deep $12 \mathrm{gal} / \mathrm{min}$ water-bearing zone \\
\hline BK-2521 & 229 & 20 & $190-210$ & $\begin{array}{l}\text { Intermediate-depth water-bearing zone at } 198-200 \mathrm{ft} \text { bls (see caliper log in } \\
\text { appendix 1, fig. } 21 \text { ) }\end{array}$ \\
\hline BK-2522 & 159 & 60 & 132-157 & $\begin{array}{l}\text { Intermediate-depth water-bearing zone at } 146 \mathrm{ft} \text { bls (see caliper log in } \\
\text { appendix } 1, \text { fig. 22). The geophysical logs indicate that this fracture } \\
\text { probably is a water-receiving zone. }\end{array}$ \\
\hline BK-2523 & 53 & 10 & $23.5-43.5$ & $\begin{array}{l}\text { Shallow water-bearing zone from } 30 \text { to } 42.5 \mathrm{ft} \text { bls (see caliper log in } \\
\text { appendix } 1 \text {, fig. 23) }\end{array}$ \\
\hline BK-2524 & 158 & $>\mathbf{8 0}$ & 115-135 & $\begin{array}{l}\text { Intermediate-depth water-bearing zone at } 123-129.5 \mathrm{ft} \text { bls (see caliper log } \\
\text { in appendix 1, fig. 24) }\end{array}$ \\
\hline BK-2525 & 80 & 4 & $31-51$ & $\begin{array}{l}\text { Shallow water-bearing zone at } 34-35 \mathrm{ft} \text { bls (see caliper log in appendix } 1 \text {, } \\
\text { fig. 25). }\end{array}$ \\
\hline BK-2526 & 79 & 4 & $50-70$ & $\begin{array}{l}\text { Shallow water-bearing zones at } 55-57 \text { and } 60 \mathrm{ft} \text { bls (see caliper log in } \\
\text { appendix } 1 \text {, fig. 26) }\end{array}$ \\
\hline BK-2527 & 201 & 5 & $157-187$ & $\begin{array}{l}\text { Intermediate-depth water-bearing zone at } 163 \mathrm{ft} \text { bls (see caliper log in } \\
\text { appendix 1, fig. 27) }\end{array}$ \\
\hline BK-2528 & 53.5 & $<1$ & $25-45$ & Shallow water-bearing zone \\
\hline
\end{tabular}




\section{Aquifer-Isolation Tests}

A straddle packer assembly was used to isolate discrete intervals in the five deep exploratory boreholes (BK-2511, BK-2512, BK-2513, BK-2514, BK-2515) and one offsite borehole (MG-1242) to determine depth- discrete specific capacity and to obtain depthdiscrete water samples. The packer assembly consisted of two $7.2-\mathrm{ft}$ long inflatable packers separated by $20.8 \mathrm{ft}$ of perforated pipe (fig. 4).

For the onsite boreholes, the distance from the center of the upper packer to the center of the lower packer was $28 \mathrm{ft}$. For the offsite borehole (MG-1242), the distance from the center of the upper packer to the center of the lower packer was $25 \mathrm{ft}$. Packer settings given in tables in this report are from the center of the upper packer to the center of the lower packer. The transducer in the isolated zone was $16.25 \mathrm{ft}$ below the center of the upper packer. The transducer below the packer string was $3.88 \mathrm{ft}$ below the center of the lower packer.

The packer assembly was lowered to the selected depth in the borehole with 2-in. diameter drill-stem pipe, and the two packers were inflated against the borehole wall, isolating the selected interval. Inflation of the packers created three zones--an isolated interval between the inflated packers, an interval above the upper packer, and an interval below the lower packer (fig. 4). Two measures were taken to ensure that the isolated interval was hydraulically isolated from the overlying and underlying intervals. First, packer inflation pressures were monitored continuously. They remained constant throughout each test. Second, water levels were monitored in all three intervals.

Generally, the lower packer was inflated first, and the upper packer was inflated after water levels above and below the lower packer had stabilized. After both packers were inflated, water levels in each zone were allowed to reach static levels. Water levels were measured by transducers or electric measuring tape. When water levels stabilized, pumping began. However, water levels in some zones did not stabilize because of interference caused by pumping of nearby public-supply wells.

\section{Ground-Water Sampling}

Water samples to be analyzed for VOC's were pumped from each isolated interval with a submersible pump set in the isolated interval through the drill-stem pipe (fig. 4). Before collecting a water sample, each isolated zone was pumped until at least three volumes were purged from the isolated interval or until successive temperature and specific-conductance measurements varied by less than 10 percent. The volume of water pumped from each isolated interval was measured. The samples were analyzed at the USGS New Jersey District laboratory in Trenton with a gas chromatograph using a photoionization detector and an electrolytic conductivity detector in series. The analytical method used is a modification of USEPA methods 601 and 602 and is described by Kammer and Gibbs (1989). The detection level is $0.8 \mu \mathrm{g} / \mathrm{L}$ for samples run by the USGS New Jersey District laboratory. A duplicate sample from each borehole was analyzed by the USGS National Water Quality Laboratory in Arvada, Colo. The detection level for these samples is $0.2 \mu \mathrm{g} / \mathrm{L}$. Analytical data for each sample are given in appendix 5 .

\section{Water-Level Measurements}

Water levels in each onsite monitor well or borehole were measured with a continuous water-level recorder utilizing a strip chart. The chart drum was connected by a gear assembly to a float wheel. A float and counter weight assembly on beaded cable in the well rose and fell with the water level. The changes were recorded as a continuous graph on the chart. Hydrographs are presented in appendix 4. 

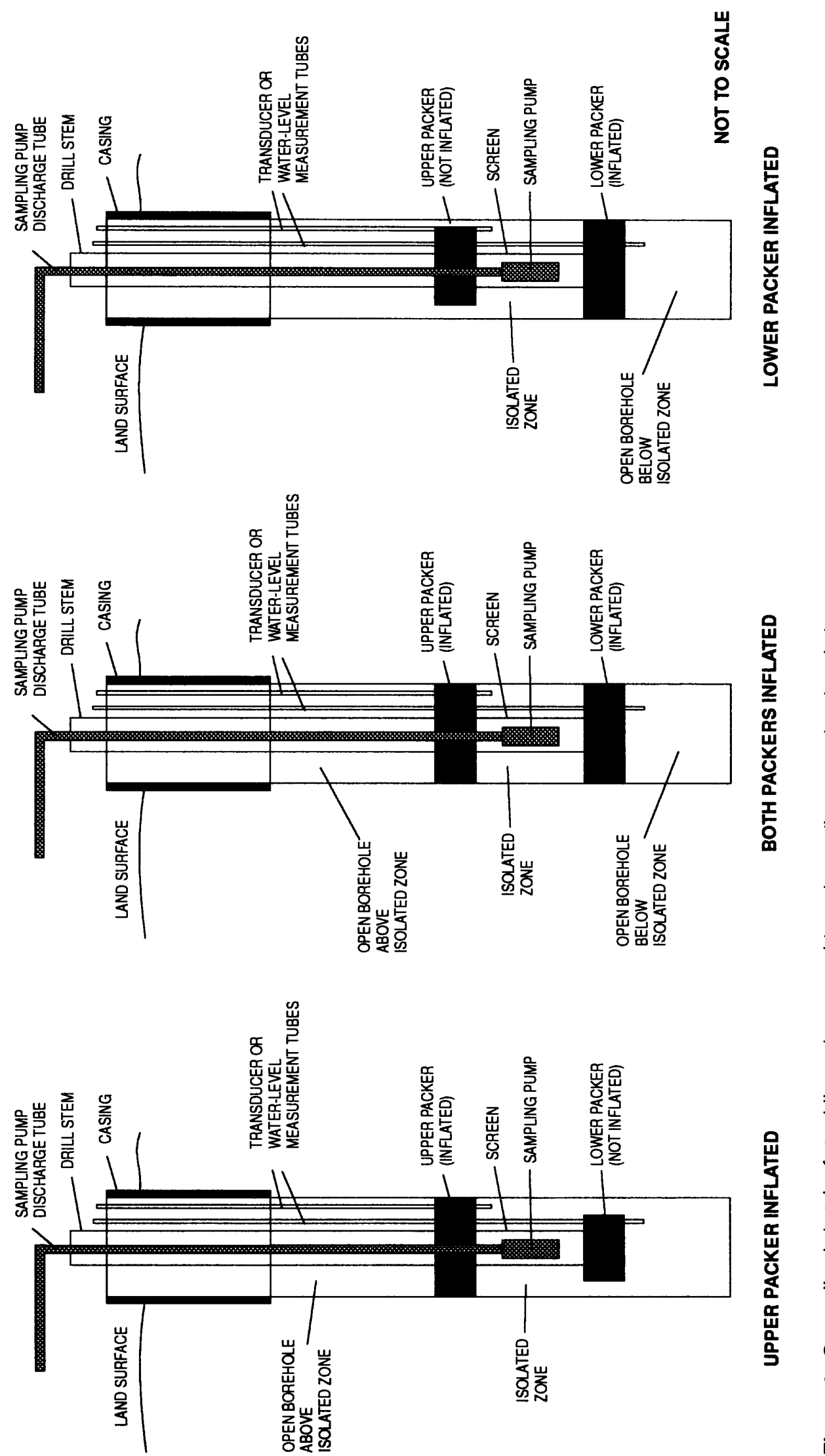

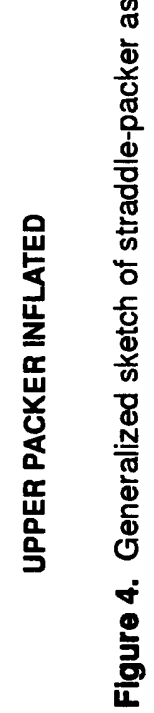




\section{GEOLOGY AND GEOHYDROLOGY}

\section{Geology}

The Fischer and Porter Site and surrounding area are underlain by sedimentary rocks of the Stockton Formation of Upper Triassic age. The Stockton Formation is the basal unit of the Newark Supergroup rocks in the Triassic-Jurassic Newark Basin. This basin contains 16,000 to $20,000 \mathrm{ft}$ of nonmarine sedimentary rocks. The Newark Basin is approximately $140 \mathrm{mi}$ long and $32 \mathrm{mi}$ wide and is the largest of the 13 major exposed Triassic-Jurassic rift basins stretching from Nova Scotia to South Carolina. Sedimentation was the result of infilling of a rift basin formed during the initial stages of continental breakup (Turner-Peterson and Smoot, 1985, p. 10). Sedimentation in the Newark Basin began with an influx of arkosic detritus from uplifted crystalline rocks to the south not far from the present day southern basin margin (Glaeser, 1966, p. 26). One of the characteristics of the Stockton is the thick-bedded to locally massive arkosic sandstones. The sediments were deposited on folded and deeply eroded Precambrian and Paleozoic rocks. The basin filled with thousands of feet of sediments over a period of about 45 million years.

The Stockton Formation is subdivided into three units called the lower arkose, middle arkose, and upper shale members by Rima and others (1962). The rocks that underlie the site belong to the middle arkose member. The Stockton Formation is 6,000 $\mathrm{ft}$ thick near the Bucks and Montgomery County boundary; the middle arkose member accounts for 70 percent of its thickness. In the vicinity of the Fischer and Porter Site, the Stockton Formation strikes approximately N. $65^{\circ} \mathrm{E}$. and dips approximately $9^{\circ} \mathrm{NW}$. (Sloto and others, 1992). The rocks are chiefly arkosic sandstone and siltstone. Quartz and feldspar are the dominant minerals.

The Stockton Formation includes alluvial fans, fluvial and lacustrine sandstones, and fluvial and near-shore lacustrine siltstones (Turner-Peterson and Smoot, 1985). Near the southern margin, the Stockton contains laterally coalescing alluvial fans deposited by well-established streams. Sediments in thick, poorly defined upward fining cycles possibly were deposited by large, perennial, meandering rivers.

Three continuous rock cores were collected at the Fischer and Porter Site to provide a continuous record of site geology and reference points to correlate geophysical logs to lithology. Rock cores from coreholes BK-2516, BK-2517, and BK-2518 extend from near land surface to a depth of 262, 277, and $274.5 \mathrm{ft}$ bls, respectively. Geologic descriptions of the cores are given in appendix 2 . On the basis of visual identification of the cores, eight lithologies were identified. They are:

(1) reddish-brown or dark purple-gray, sometimes micaceous siltstone,

(2) pinkish-gray, silty, fine-grained sandstone,

(3) dark gray, very fine-grained sandstone,

(4) gray, fine-grained sandstone,

(5) gray, poorly sorted, fine- to medium-grained sandstone,

(6) gray, medium-grained sandstone,

(7) light gray, medium- to coarse-grained sandstone, and

(8) light gray or brown conglomerate. 
Each lithology has a certain amount of variability of percent silt, percent organic content (lignite), amount of disseminated iron oxides in pore spaces, number of stylolites, and frequency of fractures. Organic material is accompanied by a localized abundance of sulfide minerals. The majority of fractures are either filled or partly lined with calcite or kaolinite (in the siltstone units). Some fractures are coated with a light green, soapy textured mineral identified by $\mathrm{X}$-ray diffraction analysis as muscovite.

The three rock cores show many gradational lithologic units consistent with the fluvial-deltaic depositional environment of the Stockton Formation. A few transitional lithologic units are characterized as a combination of two lithologic units. Transitional lithologic units appear banded or randomly mixed from units above and below. Some portions of the rock cores show bedding structures that dip up to $30^{\circ}$ from the horizontal of the core orientation. Stylolites also appear with similar dip angles.

The rock cores were compared to the single-point-resistance, natural-gamma, and caliper logs of each corehole. The labels on plates 1 and 2 and the correlation between lithologic units and the response seen in the geophysical logs (pl. 1 and 2) are:

(S) siltstone-elevated natural-gamma and weak single-point-resistance response

(SS) silty, fine-grained sandstone-fluctuating natural-gamma and moderate single-point-resistance response

(VF) very fine-grained sandstone and (F) fine-grained sandstone-weak natural-gamma and strong single-point-resistance response

(M) poorly sorted, fine- to medium-grained sandstone and mediumgrained sandstone - weak natural-gamma and moderate single-pointresistance response (less than that of the fine-grained sandstone)

(C) medium- to coarse-grained sandstone and (CG) conglomerate-weak natural-gamma and moderate to strong single-point-resistance response (weaker than that of the fine-grained sandstone and stronger than that of the medium-grained sandstone)

A few poorly sorted, coarse-grained sandstone and conglomerate units in the rock cores have a moderate natural-gamma response similar to the response of the siltstone units, possibly because of a higher muscovite content.

The difference between some units is not discernible on the geophysical logs when the beds are thin and fall between two units with very different single-point-resistance responses. Thin beds, generally less than $5 \mathrm{ft}$ thick, could not be correlated from the coreholes to adjacent boreholes. These thin units either pinch out or grade into other units.

Geophysical logs are not available for wells BK-366 and BK-367, which are active public-supply wells; therefore, driller's logs from these wells were used for correlation. The driller's logs for wells BK-366 and BK-367 are from USGS files. The entire section penetrated by well MG-946 is stratigraphically above the strata underlying the Fischer and Porter Site.

The number of lithologic units in the three cores was reduced by redefining lithologic boundaries on the basis of single-point-resistance-log response instead of megascopic textural descriptions alone. In addition, the difference between some units is difficult to discern from the geophysical logs, especially for very similar lithologic units, such as medium-grained sandstone and coarse-grained sandstone or when the beds are thin and fall between two units with very different electrical responses. Color variations are not consistently reflected by the geophysical logs, and color is not considered a diagnostic feature. Considering the observations above, some lithostratigraphic correlations across the site may either misidentify or miss a unit. 
In the core from corehole BK-2516, 48 lithostratigraphic units were identified (appendix 1, table 1). On the basis of the correlation between the core and the geophysical logs, 25 lithostratigraphic units were easily discernible. In the core from corehole BK-2517, 62 lithostratigraphic units were identified (appendix 1, table 2). On the basis of the correlation between the core and the geophysical logs, 24 lithostratigraphic units were easily discernible. Abundant fractures near the land surface interfere with the geophysical response of a fine-grained sandstone unit. In the core from corehole BK-2518, 61 lithostratigraphic units were identified to a depth of $209 \mathrm{ft}$ bls; and 81 units were identified to a depth of $274.5 \mathrm{ft}$ bls (appendix 1, table 3). The core extends to $274.5 \mathrm{ft}$ bls, but geophysical logs were run only to a depth of $209 \mathrm{ft}$ bls because of collapse of the hole. On the basis of the correlation between the core and the geophysical logs, 21 lithostratigraphic units were easily discernible.

\section{Lithostratigraphy}

The lithostratigraphy of the Fischer and Porter Site is shown on plates 1 and 2, which show the correlation of borehole geophysical logs from one rock core and eight boreholes and wells at and near the site. Plate 1 shows the interpreted lithostratigraphic correlation of geophysical logs projected to a line approximately parallel to strike. Section A-A' extends northeastward from borehole MG-1242 to well BK-366. Plate 2 shows the interpreted lithostratigraphic correlation of geophysical logs projected to a line approximately parallel to dip. Section B-B' extends eastward from borehole BK-2512 to well BK-367. The upper left corner of the scale to the left of each caliper log is the spatially correct land-surface location of each borehole. Lithostratigraphic interpretations and correlations were based on the relative response of the geophysical logs to lithology. Variations in natural-gamma and single-point-resistance responses correspond to compositional and textural variations within lithologic units. Thin interbeds in each unit also account for some variation in log response.

Because the lithologic units of the Stockton Formation grade, interfinger, and coalesce, none of the units could be used as marker beds within the lithostratigraphic sequence at the site. Therefore, the interpreted lithology of each borehole was initially developed from correlation with rock cores and then extended along strike or dip to the next nearest borehole location to correlate lithostratigraphy. Some lithostratigraphic units correlate above or below the expected projection line, probably because of the lens-like structure characteristic of alluvial-fan environments. Correlations between boreholes generally are consistent with strike and dip but show the thinning and thickening of units across the site. The accuracy of the correlations deteriorate near land surface because of the absence of single-point-resistance measurements and dampened natural-gamma response caused by casing.

\section{Generalized Stratigraphic Model}

The site lithostratigraphy presented on plates 1 and 2 was simplified by combining individual lithologic units into generalized sedimentary cycles, which are shown on plate 3. Some siltstone units are continuous under the entire Fischer and Porter Site and can be traced from borehole to borehole. These siltstone units are numbered on plates 1 and 2 (S5, for example). The numbered siltstone units are the top unit of a poorly defined, upward fining sedimentary cycle. These cycles are shown on plate 3 (unit 5 , for example). Numbered sedimentary cycles shown on plate 3 correspond to the numbered siltstone units shown on plates 1 and 2; for example, unit 5 is the sedimentary cycle shown on plate 3 capped by siltstone unit $\mathrm{S} 5$, which is shown on plate 1 . Grouping individual lithologic units into sedimentary cycle units simplifies the geologic framework and more easily permits tracing the lithology from borehole to borehole. 


\section{Geohydrology}

In the Stockton Formation, the hydrologic system operates within the geologic framework but is somewhat independent of it. Ground water in the weathered zone moves through intergranular openings that have formed as a result of weathering. In some places, permeability of the weathered zone may be poor because of a high percentage of clay derived from weathering of siltstone. Ground water in the unweathered zone mainly moves through a network of interconnecting secondary openings-fractures, bedding planes, and joints. Beds within the Stockton Formation are hydraulically connected by vertical joints that cross each other at various angles. Thus, ground water may move across beds, particularly in the direction of dip, rather than through individual beds.

In general, the sandstone units are the principle water-bearing units, but some of the finer-grained units may contain water-bearing openings. However, because of the softness and fine grain size of the siltstone units, water-bearing openings tend to be clogged. In addition, the soft siltstone beds deform without breaking under stress and, as a result, have lower permeability than the harder sandstone beds, which tend to develop fractures and joints and are more permeable.

Some water-bearing openings may be slightly enlarged by circulating ground water, which has decomposed and disintegrated mineral constituents in the walls of fractures. Primary porosity that may have originally existed has been almost eliminated by compaction and cementation. Some water may move through intergranular openings in the rock below the weathered zone where the cement has been removed and the permeability has increased, but this generally is restricted to a few coarse-grained sandstone and conglomerate beds. Laboratory hydraulic conductivities were run on core sections collected $0.5 \mathrm{mi}$ south of the Fischer and Porter Site. Red siltstone had a hydraulic conductivity of $5.14 \times 10^{-7} \mathrm{ft} / \mathrm{d}$; red, silty, fine-grained sandstone had a hydraulic conductivity of $2.92 \times 10^{-6} \mathrm{ft} / \mathrm{d}$; gray, fine-grained sandstone had a hydraulic conductivity of $1.18 \times 10^{-4} \mathrm{ft} / \mathrm{d}$; and medium- to coarse-grained sandstone (with some cement removed) had a hydraulic conductivity of $0.19 \mathrm{ft} / \mathrm{d}$.

The rocks of the Stockton Formation form a complex, heterogeneous, multiaquifer system. This aquifer system is comprised of a series of gently dipping lithologic units with different hydraulic properties. The ground-water system can be visualized as a series of beds with a relatively high transmissivity separated by beds with a relatively low transmissivity. The beds, a few inches to a few feet thick, act as a series of alternating aquifers and confining or semiconfining units that form a leaky, multiaquifer system. Each bed generally has different hydraulic properties, and permeability commonly differs from one bed to another.

Ground water is unconfined in the shallower part of the aquifer and confined or semiconfined in the deeper part of the aquifer. Under confined conditions, ground water is confined under pressure greater than atmospheric by overlying, less permeable lithologic units and is not free to rise and fall. Differences in the ratio of vertical to horizontal hydraulic conductivity, as well as differences in vertical hydraulic conductivity within and among lithologic units, create confining conditions.

Nearly all deep wells in the Stockton Formation are open to several water-bearing zones and are multiaquifer wells. Each water-bearing zone usually has a different hydraulic head. The hydraulic head in a deep, open-hole well is the composite of the heads in the several water-bearing zones penetrated. This can cause water levels in some wells to be different than water levels in adjacent wells of different depths. Where differences in hydraulic head exist between water-bearing zones, water in the well bore flows under nonpumping conditions in the direction of decreasing head. Water moves 
downward through the aquifer system in response to this downward head gradient, which is caused in part by the pumping of deep public-supply wells and the Fischer and Porter treatment system extraction wells.

\section{Geohydrology at Existing Boreholes}

In September and October of 1992, borehole geophysical logs were run in all existing, nonpumping boreholes, and borehole-flow measurements were made in selected boreholes to (1) locate subsurface fractures; (2) identify, where possible, important waterbearing fractures; (3) identify zones of potential borehole flow; (4) measure direction and rate of natural borehole flow; and (5) aid in characterization of the ground-water-flow system. Figure 2 shows the location of the wells and table 1 provides construction data. Geophysical logs are presented in appendix 1.

\section{BK-372}

Borehole BK-372, which was located in a pit inside a quonset hut, was originally drilled to $601 \mathrm{ft}$ bls in 1952 but had collapsed. It was logged to a depth of $442 \mathrm{ft}$ on March 1,1991 , and to a depth of $435 \mathrm{ft}$ on September 8, 1992. The borehole was cased with 10-in. diameter steel casing to $49.5 \mathrm{ft}$ below the quonset hut floor level. The caliper log (appendix 1, figs. 1 and 2) shows major fractures at 56, 65.5, 177, 205, 280, 345.5, 374-388, and 422$436 \mathrm{ft}$ bls and numerous smaller fractures. The fracture zones from 374 to 388 and 422 to $436 \mathrm{ft}$ bls are collapse zones that contributed the material filling the borehole. A partially collapsed zone that reduces the borehole diameter to 4.25 in. is at $63 \mathrm{ft}$ bls. The gamma and single-point- resistance logs show that siltstone units correlate with the collapsed zones shown on the caliper log. Borehole BK-372 was abandoned when it was filled with a cement grout-bentonite mixture by a USEPA contractor in the fall of 1992.

On March 1, 1991, slugs of high-conductance fluid were injected in the borehole at depths of 130, 185, 190, 250, 310, 355, and $400 \mathrm{ft}$ bls. Upward borehole flow of $2.0 \mathrm{gal} / \mathrm{min}$ was measured at 400 and $355 \mathrm{ft}$ bls (fig. 5). Upward borehole flow of $0.5 \mathrm{gal} / \mathrm{min}$ was measured at $250 \mathrm{ft}$ bls. No flow was measurable at 130, 185, 190, or $310 \mathrm{ft}$ bls. On September 8, 1992, while the Fischer and Porter treatment system wells were shut down, slugs of high-conductance fluid were injected in the borehole at depths of 130, 190, 250, 300,360 , and $400 \mathrm{ft}$ bls. No borehole flow was measurable at any of these depths. The upward flow measured on March 1, 1991, may have been caused by the pumping of the Fischer and Porter treatment system wells.

The suite of geophysical logs run on March 1, 1991, indicates that water enters the borehole from the fracture zone at $422-436 \mathrm{ft}$ bls and moves upward at $2 \mathrm{gal} / \mathrm{min}$ to a fracture at $345.5 \mathrm{ft}$ bls where it exits the borehole. Water also enters the borehole from a fracture at $280 \mathrm{ft}$ bls and moves upward at $0.5 \mathrm{gal} / \mathrm{min}$ to a fracture at $205 \mathrm{ft}$ bls where it exits the borehole. A zone of no flow is present between the two zones of flow.

\section{BK-1324}

Well BK-1324, which is an extraction well for the Fischer and Porter treatment system, was logged to a depth of $299 \mathrm{ft}$ on September 20, 1990, when the pump was removed from the well. The caliper log (appendix 1, fig. 3) shows that the well is cased with $19 \mathrm{ft}$ of 6 -in. diameter casing. The caliper log shows minor fractures at 25.5 and $40.5 \mathrm{ft}$ bls. The fluidresistivity and fluid-temperature logs do not indicate borehole flow. Borehole-flow measurements were not made because of a considerable quantity of free product floating on the water surface. 


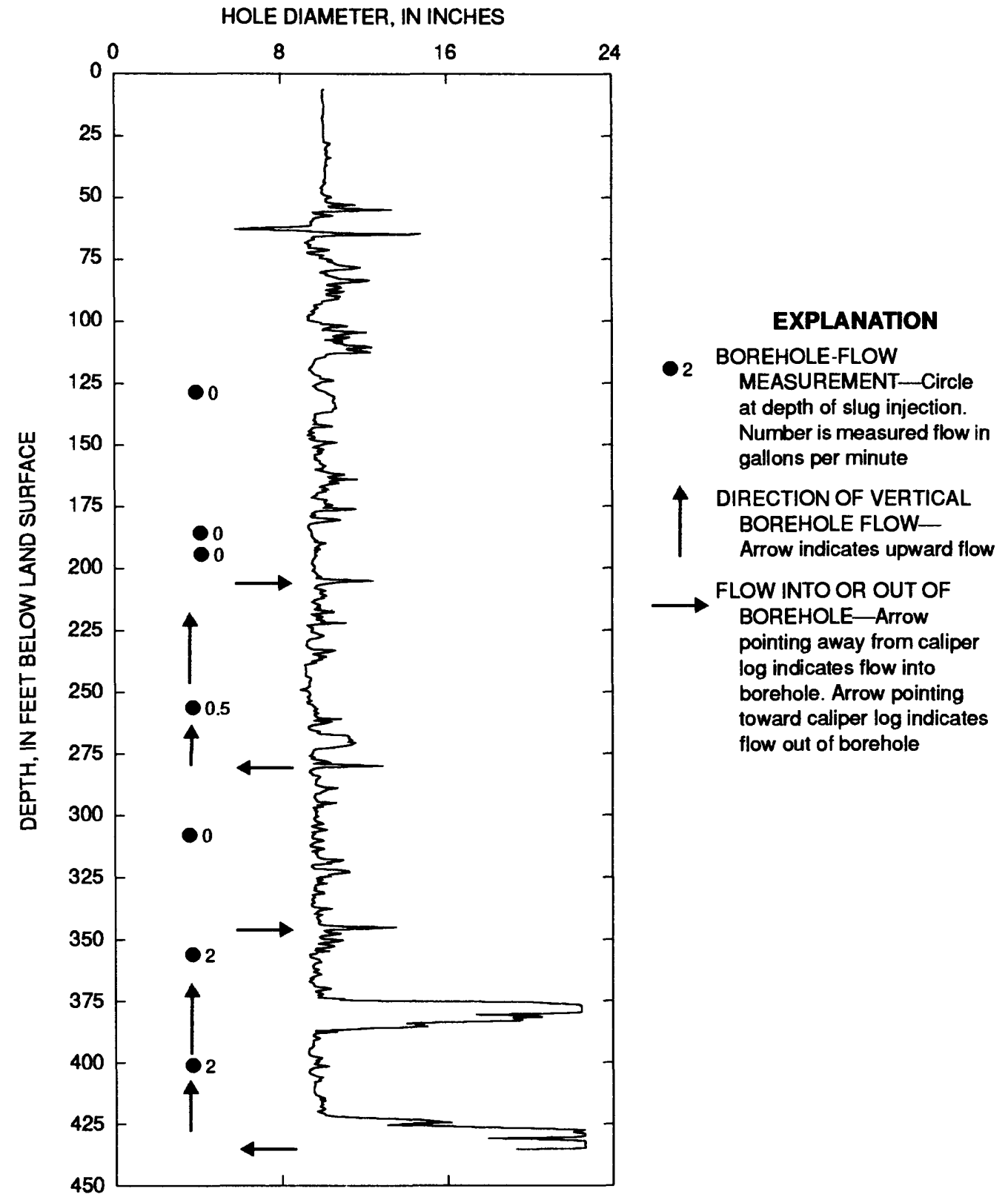

Flgure 5. Caliper log from borehole BK-372 showing borehole-flow measurements, Fischer and Porter Site, Warminster, Pa., March 1, 1991.

\section{BK-1731}

Borehole BK-1731 was drilled to $300 \mathrm{ft}$ bls on May 22-24, 1991. The borehole collapsed. It was logged to a depth of $140 \mathrm{ft}$ on May 31, 1991, and to a depth of $69 \mathrm{ft}$ on September 14, 1992. The borehole is cased with 6-in. diameter steel casing to $47 \mathrm{ft}$ bls. The caliper log (appendix 1, figs. 4 and 5) shows major fractures at 47.5, 59, 78.5, 88-89, and 139-140 ft bls. The natural-gamma log shows a contact between a sandstone unit (from the bottom of the casing to $59 \mathrm{ft}$ bls) and a siltstone unit (below $59 \mathrm{ft}$ bls) at $59 \mathrm{ft}$ bls that correlates with a 
fracture shown on the caliper log. On September 14, 1992, a slug of high-conductance fluid was injected in the borehole at $55 \mathrm{ft}$ bls while the Fischer and Porter treatment system wells were shut down; no vertical movement was measurable.

\section{BK-1795}

Borehole BK-1795 was originally drilled to $54 \mathrm{ft}$ bls on February 7, 1980. It was logged to a depth of $31 \mathrm{ft}$ on September 14, 1992 (appendix 1, fig. 6). The borehole is cased to $23 \mathrm{ft}$ bls with 6-in. diameter steel casing. The borehole was dry when logged; therefore, only a caliper and natural-gamma log were run.

\section{BK-1796}

Borehole BK-1796 was logged to a depth of $146 \mathrm{ft}$ on September 14, 1992, while the Fischer and Porter treatment system wells were shut down and on September 28, 1992, when the Fischer and Porter treatment system wells were pumping (appendix 1, figs. 7 and 8). The borehole is cased with 6-in. diameter steel casing to $78 \mathrm{ft}$ bls. The caliper log shows minor fractures at 89.5, 96, 98, 107-109, 113, 121, and 143-144 ft bls.

The fluid-resistivity and fluid-temperature logs did not indicate borehole flow. On September 28, the water level in borehole BK-1796 was $6.39 \mathrm{ft}$ lower than on September 14 despite heavy rains 2 days prior to logging. The decrease in water level probably was caused by the pumping of the Fischer and Porter treatment system wells. The fluidresistivity log run on September 28 shows a similar pattern to that run on September 14 . However, total dissolved solids of the borehole fluid on September 28 was half of that measured on September 14, indicating recharge to the borehole. On September 28, 1992, a slug of high-conductance fluid was injected in the borehole at a depth of $110 \mathrm{ft}$ bls while the treatment system wells were pumping; no vertical movement was measurable.

\section{MG-1241}

Borehole MG-1241 was logged to a depth of $174 \mathrm{ft}$. The borehole is cased with 6-in. diameter steel casing to $21 \mathrm{ft}$ bls. The caliper $\log$ (appendix 1, figs. 9 and 10) shows a major fracture at $91 \mathrm{ft}$ bls and numerous smaller fractures.

The fluid-resistivity log run on December 7,1990 , shows breaks in slope at 54,155 , and $168 \mathrm{ft}$ bls. Fluid resistivity was constant between 54 and $155 \mathrm{ft}$ bls, indicating a potential zone of borehole flow. The fluid-resistivity log run on September 9, 1992, shows breaks in slope at 75 and $160 \mathrm{ft}$ bls. The fluid-temperature $\log$ run on December 7, 1990, shows a low gradient between 39 and $137 \mathrm{ft}$ bls and breaks in slope at 137, 148, and $155 \mathrm{ft}$ bls. The fluid-temperature log run on September 9, 1992, shows breaks in slope at 136, 147, and $155 \mathrm{ft}$ bls. The fluid-temperature logs run on December 7, 1990, indicate borehole flow, but the logs are difficult to evaluate because the water level in borehole MG-1241 is greatly affected by the pumping of Hatboro public-supply well MG-947, which is $1,350 \mathrm{ft}$ to the west. Pumping of well MG-947 causes a daily water-level change of approximately 6 to $7 \mathrm{ft}$ in borehole MG-1241 (fig. 6).

On December 7,1990, slugs of high-conductance fluid were injected in the borehole at $65,110,145$, and $160 \mathrm{ft}$ bls. At 110 and $145 \mathrm{ft} \mathrm{bls}$, downward flow of less than $0.5 \mathrm{gal} / \mathrm{min}$ was observed. No borehole flow was measurable at 65 and $160 \mathrm{ft}$ bls. On September 9 , 1992 , slugs of high-conductance fluid were injected at the same depths. Measured downward flows were $1.5 \mathrm{gal} / \mathrm{min}$ at $110 \mathrm{ft} \mathrm{bls,} 1.1 \mathrm{gal} / \mathrm{min}$ at $145 \mathrm{ft} \mathrm{bls}$, and less than $0.5 \mathrm{gal} / \mathrm{min}$ at 65 and $160 \mathrm{ft}$ bls. The differences in flow observed between the measurements made in December of 1990 and September of 1992 may be due, in part, to differences in pumping of well MG-947. 
The suite of geophysical logs indicates that a small quantity of water enters the borehole from a fracture at $48 \mathrm{ft}$ bls and moves downward (fig. 7). Additional water enters the borehole from a fracture at $75 \mathrm{ft}$ bls for a total inflow of $1.5 \mathrm{gal} / \mathrm{min}$. The water flows downward and exits the borehole through fractures at 158 and $168 \mathrm{ft}$ bls.

\section{MG-1242}

Borehole MG-1242 was logged to a depth of $177 \mathrm{ft}$. The borehole is cased with 6-in. diameter steel casing to $19 \mathrm{ft}$ bls. The caliper log (appendix 1, figs. 11 and 12) shows major fractures at 24, 70, and $156 \mathrm{ft}$ bls plus numerous smaller fractures.

The fluid-resistivity log run on December 7, 1990, shows changes in slope at 70 and $82 \mathrm{ft}$ bls, which indicate possible fluid-producing zones. The log shows little gradient between 82 and $171 \mathrm{ft}$ bls, which indicates a zone of borehole flow. The fluid-resistivity log run on September 9, 1992, shows changes in slope at 70, 76, and $172 \mathrm{ft} \mathrm{bls.} \mathrm{The} \mathrm{fluid-}$ temperature log run on December 7, 1990, shows little gradient between 44 and $160 \mathrm{ft}$ bls, which indicates a zone of borehole flow. The fluid-temperature log run on September 9, 1992, shows a change in slope at $169 \mathrm{ft}$ bls and little gradient between 55 and $168 \mathrm{ft}$ bls.

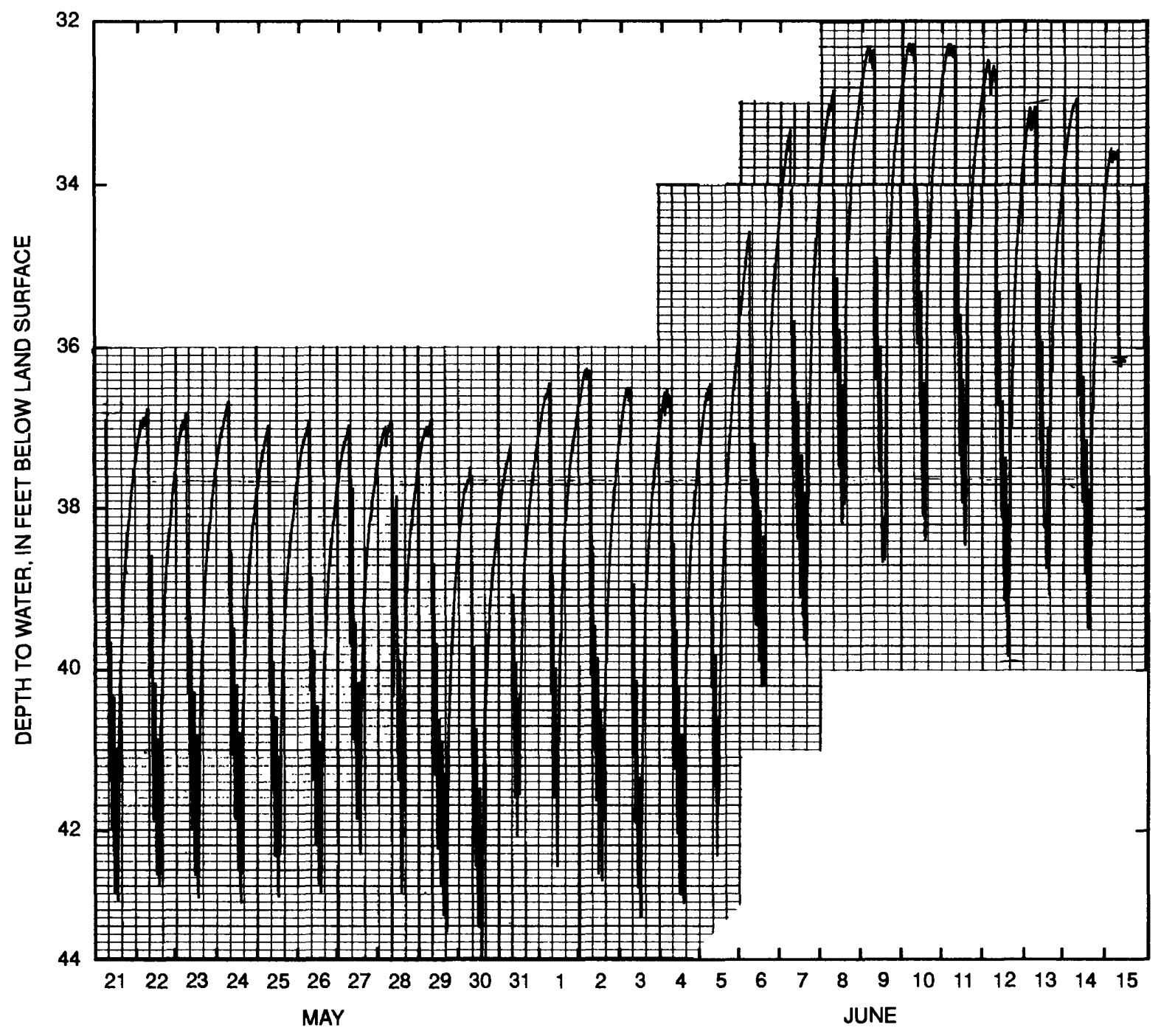

Figure 6. Hydrograph of borehole MG-1241, Hatboro, Pa., May 21 to June 15, 1992. 


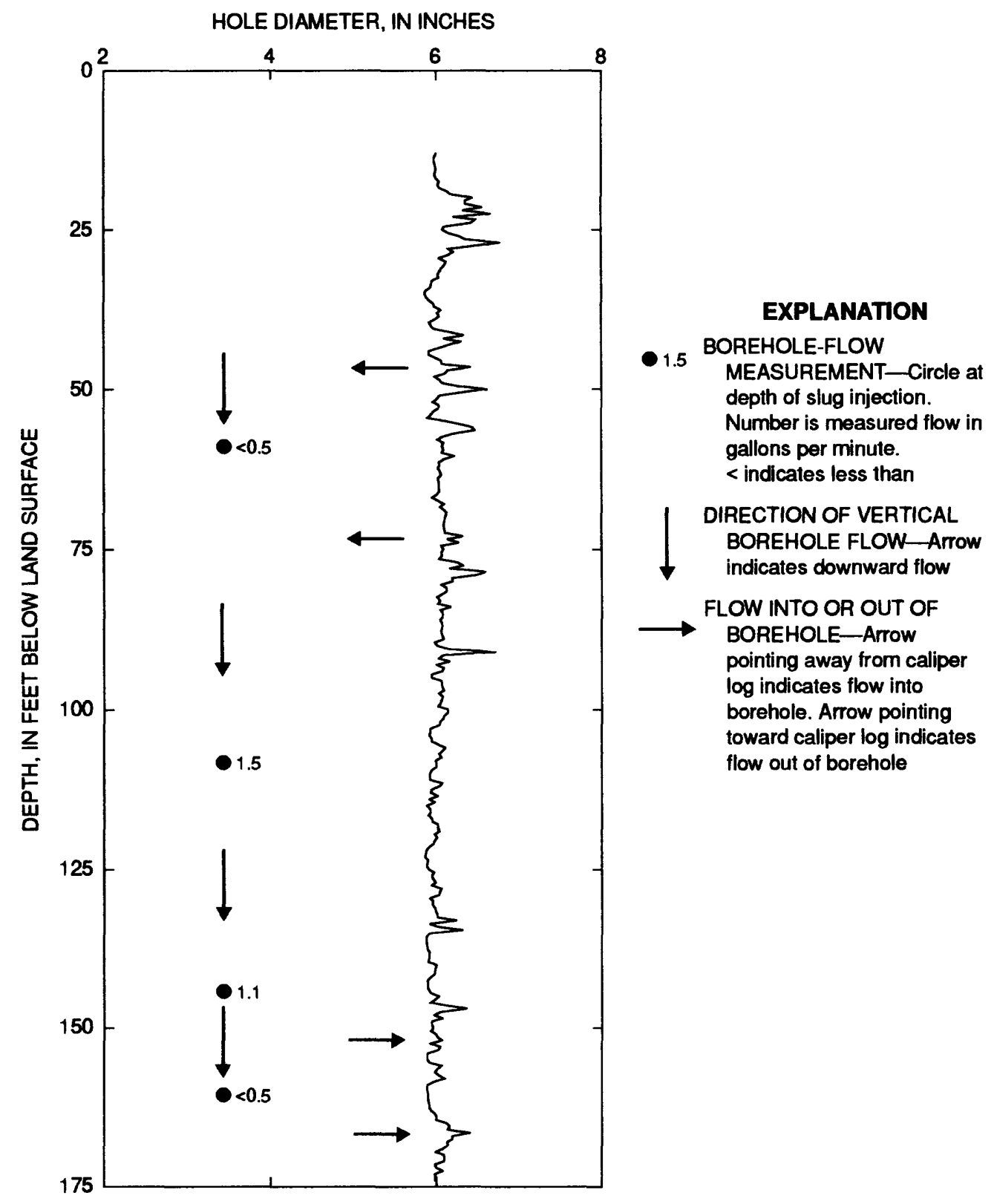

Figure 7. Caliper log from borehole MG-1241 showing borehole-flow measurements, Hatboro, Pa., September 9, 1992.

On December 7, 1990, slugs of high-conductance fluid were injected in the borehole at 60,90 , and $140 \mathrm{ft}$ bls. Downward flow of less than $0.5 \mathrm{gal} / \mathrm{min}$ was measured at 90 and $140 \mathrm{ft}$ bls. No borehole flow was measurable at $60 \mathrm{ft}$ bls. On September 9, 1992, slugs of high-conductance fluid were injected in the borehole at 65, 95, and $140 \mathrm{ft}$ bls. Downward flow of less than $0.7 \mathrm{gal} / \mathrm{min}$ was measured at $140 \mathrm{ft}$ bls. Slight downward flow was observed, but not quantifiable, at $95 \mathrm{ft}$ bls. No borehole flow was measurable at $65 \mathrm{ft}$ bls.

The suite of geophysical logs indicates that a small quantity of water enters the borehole through fractures at 70, 82, and $129 \mathrm{ft}$ bls and flows downward (fig. 8). Water exits the borehole through a fracture at $156 \mathrm{ft}$ bls. 
HOLE DIAMETER, IN INCHES

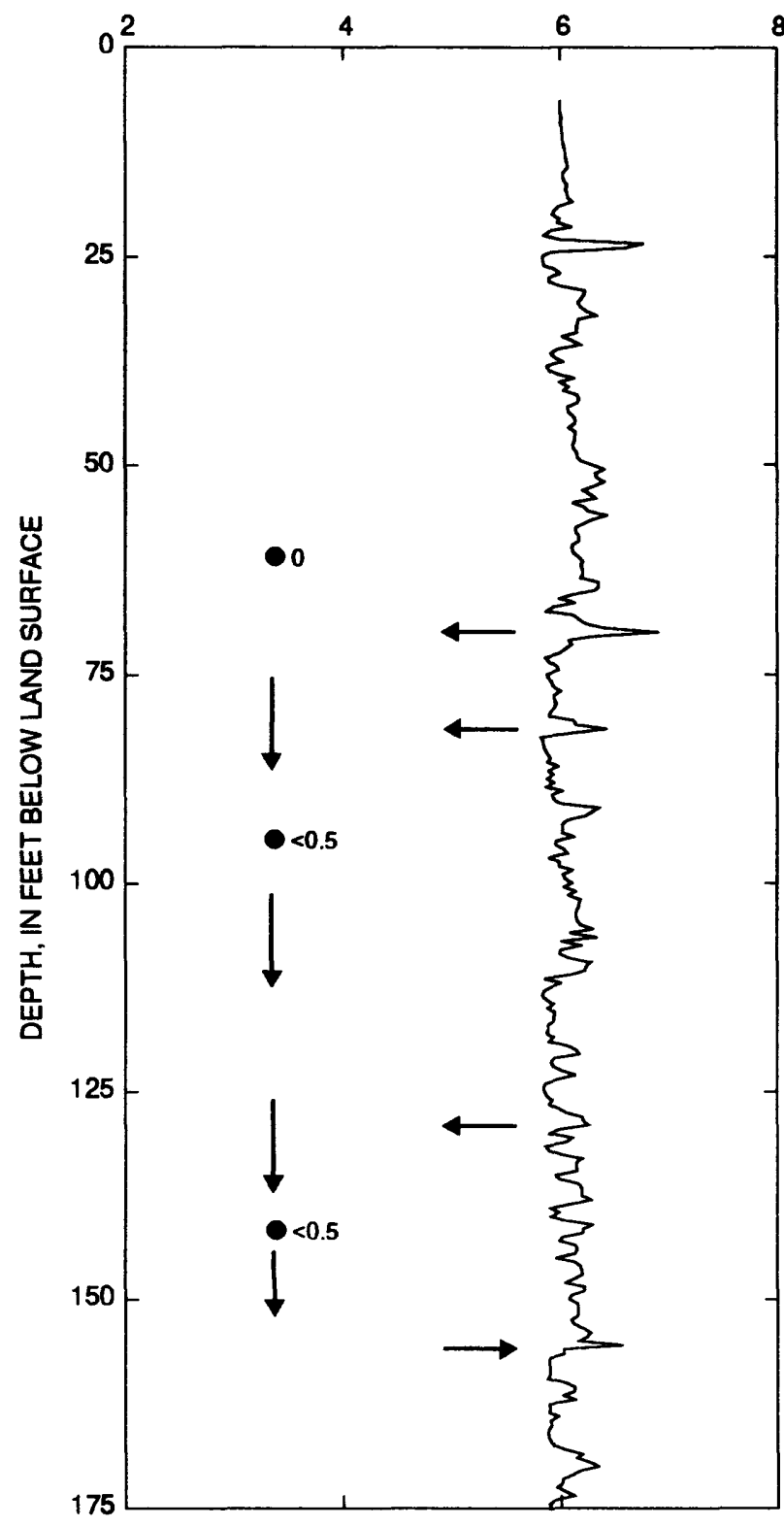

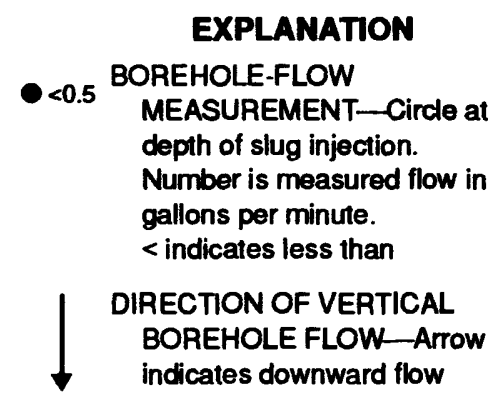

FLOW INTO OR OUT OF BOREHOLE-Arrow pointing away from caliper log indicates flow into borehole. Arrow pointing toward caliper log indicates flow out of borehole

Figure 8. Caliper log from borehole MG-1242 showing borehole-flow measurements, Hatboro, Pa., December 7, 1990. 


\section{Geohydrology at Exploratory Boreholes}

After completion of drilling, a suite of borehole geophysical logs and a borehole television survey was run in each of the exploratory boreholes.

\section{BK-2511}

Borehole BK-2511 was drilled to $352 \mathrm{ft}$ bls and cased with $146 \mathrm{ft}$ of 8-in. diameter steel casing. The yield was $15 \mathrm{gal} / \mathrm{min}$. The driller reported water-bearing zones at $170 \mathrm{ft}$ ( $5 \mathrm{gal} / \mathrm{min}), 270 \mathrm{ft}(5 \mathrm{gal} / \mathrm{min})$, and $315 \mathrm{ft}$ bls $(5 \mathrm{gal} / \mathrm{min})$. A water-bearing zone at $53 \mathrm{ft}$ bls was cased off.

Borehole BK-2511 was logged to a depth of $349 \mathrm{ft}$. The caliper log (appendix 1, fig. 13) and borehole television survey show numerous minor fractures and several major fractures. Major horizontal fractures are at 253,312, and $326.5 \mathrm{ft}$ bls. Major vertical fractures are at 147.5 and $278.5-279.5 \mathrm{ft}$ bls. The fluid-resistivity and fluid-temperature logs do not indicate borehole flow.

\section{BK-2512}

Borehole BK-2512 was drilled to $303 \mathrm{ft}$ bls and cased with $5 \mathrm{ft}$ of 12 -in. diameter steel casing and $87 \mathrm{ft}$ of 8 -in. diameter steel casing. The yield was greater than $150 \mathrm{gal} / \mathrm{min}$. The driller reported water-bearing zones at $98 \mathrm{ft}(8 \mathrm{gal} / \mathrm{min}), 106 \mathrm{ft}(7 \mathrm{gal} / \mathrm{min}), 146 \mathrm{ft}$ (20 gal $/ \mathrm{min}), 178 \mathrm{ft}$ (5 gal $/ \mathrm{min}), 189 \mathrm{ft}(20 \mathrm{gal} / \mathrm{min}), 230 \mathrm{ft}(20 \mathrm{gal} / \mathrm{min}), 245 \mathrm{ft}$ (greater than $20 \mathrm{gal} / \mathrm{min}$ ), and $250 \mathrm{ft}$ bls (greater than $50 \mathrm{gal} / \mathrm{min}$ ). A water-bearing zone at $54 \mathrm{ft}$ bls was cased off.

The caliper $\log$ (appendix 1, fig. 14) and borehole television survey show numerous minor fractures and several major fractures. Minor horizontal fractures are at 96, 101, 148, and $217 \mathrm{ft}$ bls. Major vertical fractures are at 99-101, 242-250, and 259-261 ft bls, and minor vertical fractures are at 105-109, 128-130, 137-142, and 144-146 ft bls. The large vertical fracture at $242-250 \mathrm{ft}$ bls is the dominant feature in the borehole (fig. 9).

The fluid-resistivity log shows a change in slope at 213 and $252 \mathrm{ft}$ bls. These changes in slope coincide with fractures shown on the caliper log at 217 and 242-250 $\mathrm{ft}$ bls. The fluid-temperature log shows very little gradient, which indicates borehole flow. Slugs of high-conductance fluid were injected in the borehole at 120, 190, 230, and $270 \mathrm{ft}$ bls. Downward flow at the rate of $1.7 \mathrm{gal} / \mathrm{min}$ was measured at $120 \mathrm{ft} \mathrm{bls}$, and downward flow at the rate of $1.3 \mathrm{gal} / \mathrm{min}$ was measured at $190 \mathrm{ft}$ bls. No borehole flow was measurable at 230 or $270 \mathrm{ft}$ bls.

The suite of geophysical logs indicates that water enters the borehole through a horizontal fracture at $96 \mathrm{ft}$ bls and moves downward at the rate of $1.7 \mathrm{gal} / \mathrm{min}$ (fig. 10). The borehole television survey shows a disruption of downward particle movement at this fracture. About $0.4 \mathrm{gal} / \mathrm{min}$ is lost to a fracture at $148 \mathrm{ft}$ bls. Water continues moving down the borehole at $1.3 \mathrm{gal} / \mathrm{min}$ to water-receiving fractures at 217 and $242-250 \mathrm{ft}$ bls. The borehole television survey shows a disruption of downward particle movement at the fracture at $217 \mathrm{ft}$ bls.

\section{BK-2513}

Borehole BK-2513 was drilled to $301 \mathrm{ft}$ bls and cased with $5 \mathrm{ft}$ of 12-in. diameter steel casing and $126 \mathrm{ft}$ of 8 -in. diameter steel casing. The yield was $100 \mathrm{gal} / \mathrm{min}$. The driller reported water-bearing zones at $131 \mathrm{ft}(60 \mathrm{gal} / \mathrm{min}), 160 \mathrm{ft}(20 \mathrm{gal} / \mathrm{min})$, and $171 \mathrm{ft} \mathrm{bls}$ (20 gal $/ \mathrm{min}$ ). Water-bearing zones at 60 and $120 \mathrm{ft}$ bls were cased off. 
Borehole BK-2513 was logged to a depth of $298 \mathrm{ft}$. The caliper log (appendix 1, fig. 15) and borehole television survey show numerous minor fractures and several major fractures. Major vertical fractures are at 124.5-128, 133.5-136, 146.5-156.5, 187-194, and 267$269 \mathrm{ft}$ bls. The fluid-resistivity and fluid-temperature logs do not indicate borehole flow. Slugs of high-conductance fluid were injected in the borehole at 135, 200,260, and $270 \mathrm{ft}$ bls. No borehole flow was measurable. The borehole television survey shows a disruption of downward particle movement at the fractures at 245 and $268.5 \mathrm{ft}$ bls; this may be flow across the borehole through these fractures.

\section{BK-2514}

Borehole BK-2514 was drilled to $292 \mathrm{ft}$ bls and cased with $37 \mathrm{ft}$ of 8-in. diameter steel casing. The yield was $35 \mathrm{gal} / \mathrm{min}$. The driller reported water-bearing zones at $200 \mathrm{ft}$ (5 $\mathrm{gal} / \mathrm{min}), 215 \mathrm{ft}$ ( $25 \mathrm{gal} / \mathrm{min}$ ), and below $215 \mathrm{ft} \mathrm{bls} \mathrm{(} 5 \mathrm{gal} / \mathrm{min}$ ).

The caliper $\log$ (appendix 1, fig. 16) and borehole television survey show numerous minor fractures and several major fractures. Major horizontal fractures are at 83.5, 114.5, $133,151,225$, and $250 \mathrm{ft}$ bls. Major vertical fractures are at 51-60, 95-96, and 211-213 ft bls.

The fluid-resistivity log shows a very large change in slope at $57 \mathrm{ft}$, which coincides with a large vertical fracture at 51-60 ft bls; the largest opening of this fracture is at $58 \mathrm{ft}$ bls. The fluid-temperature log shows little gradient, which indicates borehole flow. Changes in slope at 225 and $255 \mathrm{ft}$ bls coincide with horizontal fractures. Slugs of high-

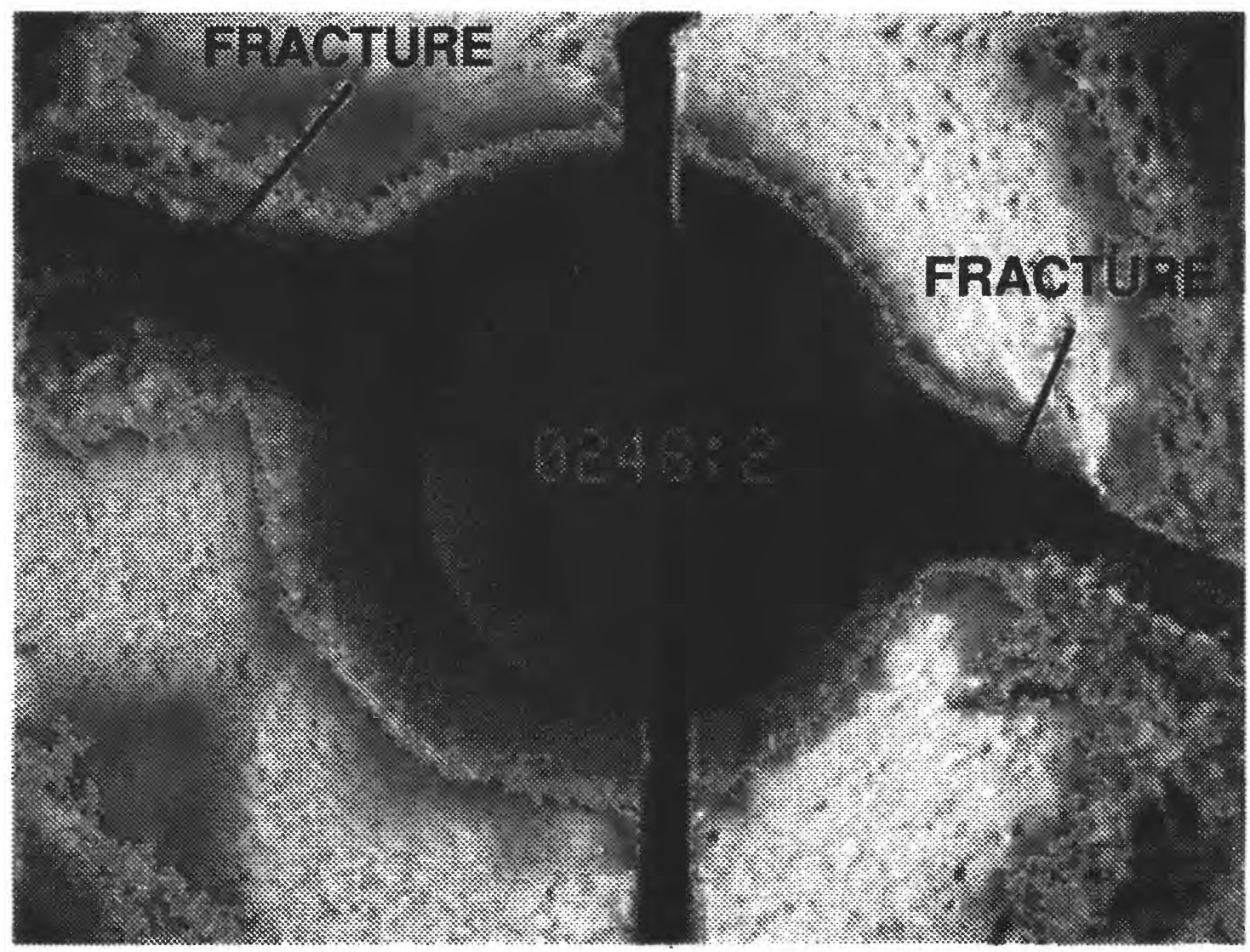

Figure 9. Photograph from borehole television survey of borehole BK-2512 showing fracture at 248.2 feet below land surface, Fischer and Porter Site, Warminster, $\mathrm{Pa}$. 
HOLE DIAMETER, IN INCHES

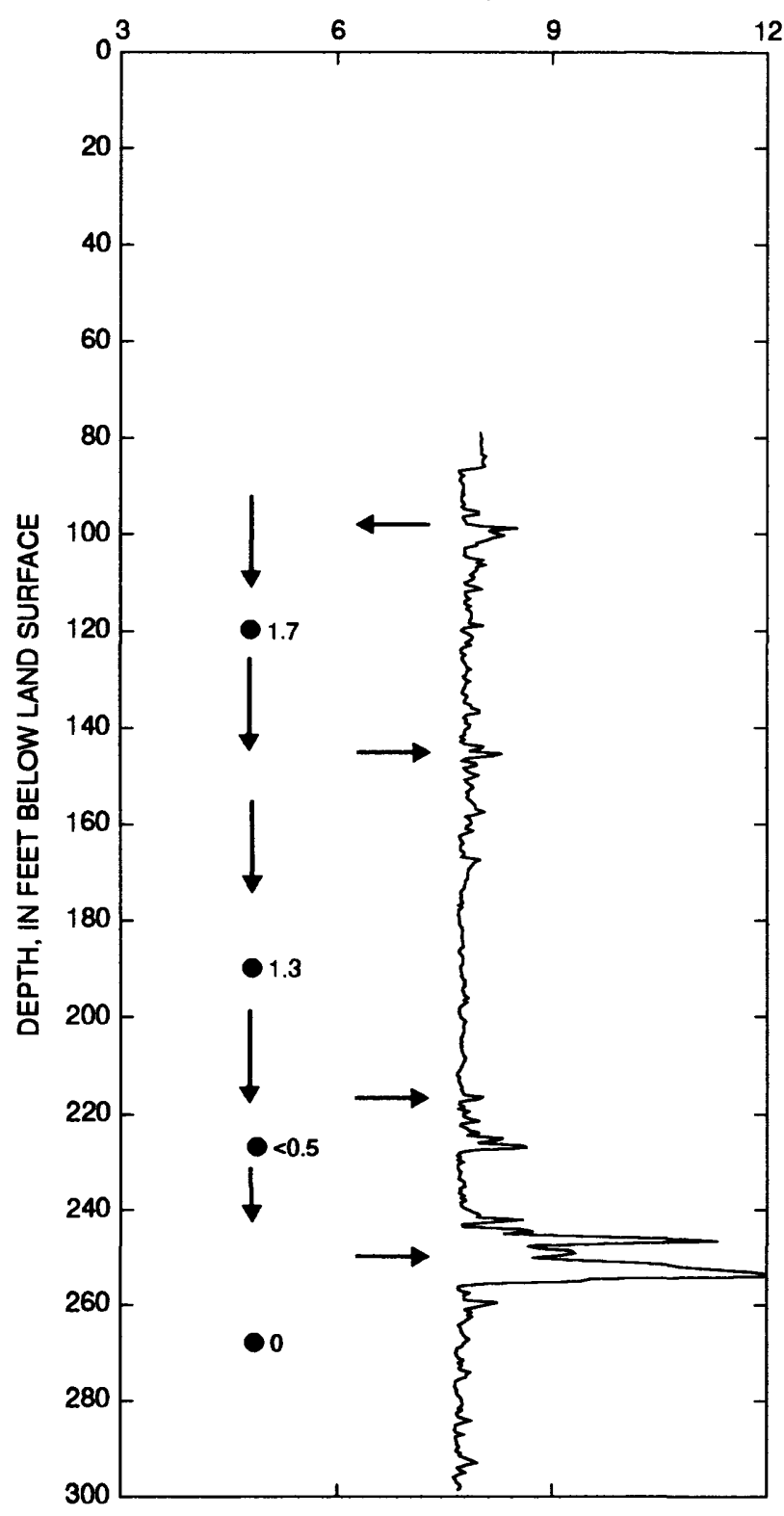

EXPLANATION

1.7 BOREHOLE-FLOW

MEASUREMENT-Circle at

depth of slug injection.

Number is measured flow in

gallons per minute

DIRECTION OF VERTICAL BOREHOLE FLOW-Arrow indicales dowmward flow

FLOW INTO OR OUT OF BOREHOLE-Arrow pointing away from caliper log indicates flow into borehole. Arrow pointing toward caliper log indicates flow out of borehole

Figure 10. Caliper log from borehole BK-2512 showing borehole-flow measurements, Fischer and Porter Site, Warminster, Pa.

conductance fluid were injected in the borehole at 80 and $170 \mathrm{ft}$ bls. Downward flow at the rate of $8.3 \mathrm{gal} / \mathrm{min}$ was measured at $80 \mathrm{ft} \mathrm{bls}$, and downward flow at the rate of $9 \mathrm{gal} / \mathrm{min}$ was measured at $170 \mathrm{ft}$ bls.

The suite of geophysical logs indicates that water enters the borehole through a vertical fracture at approximately $58 \mathrm{ft}$ bls and moves downward at the rate of $8.3 \mathrm{gal} / \mathrm{min}$ (fig. 11). An additional $0.7 \mathrm{gal} / \mathrm{min}$ enters the borehole, probably through fractures at 133 and (or) $151 \mathrm{ft}$ bls. Water continues moving down the borehole at $9 \mathrm{gal} / \mathrm{min}$ to water-receiving horizontal fractures at 225 and $250 \mathrm{ft}$ bls. 
HOLE DIAMETER, IN INCHES

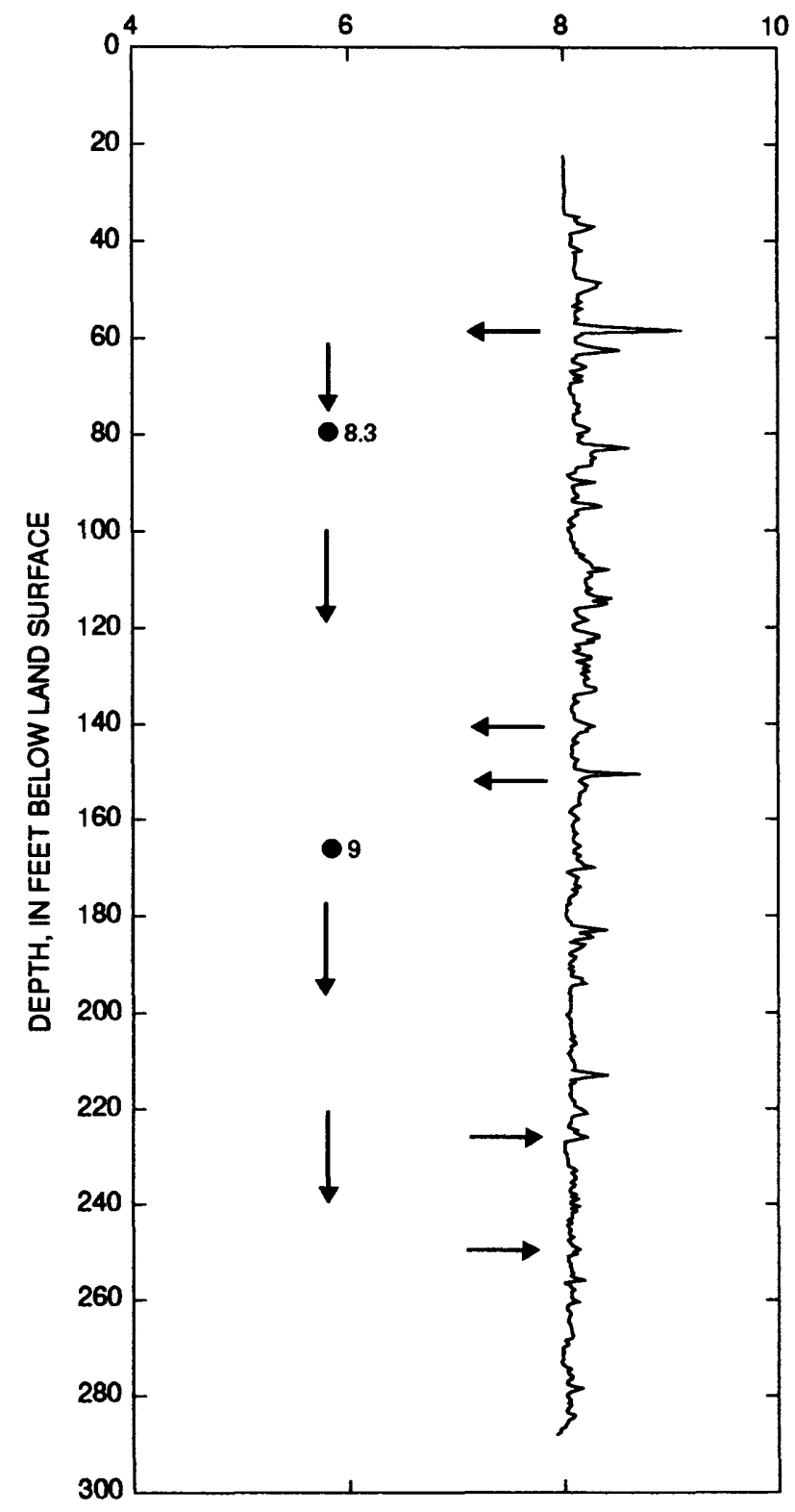

Figure 11. Caliper log from borehole BK-2514 showing borehole-flow measurements, Fischer and Porter Site, Warminster, $\mathrm{Pa}$.

\section{BK-2515}

Borehole BK-2515 was drilled to $310 \mathrm{ft}$ bls and cased with $5 \mathrm{ft}$ of 12-in. diameter steel casing and $108 \mathrm{ft}$ of 8-in. diameter steel casing. The yield was $15 \mathrm{gal} / \mathrm{min}$. The driller reported water-bearing zones at $208 \mathrm{ft}$ ( $3 \mathrm{gal} / \mathrm{min}$ ), $282-287 \mathrm{ft}(3 \mathrm{gal} / \mathrm{min})$, and $302 \mathrm{ft} \mathrm{bls}$ (9 $\mathrm{gal} / \mathrm{min})$. A water-bearing zone at $31 \mathrm{ft} \mathrm{bls} \mathrm{was} \mathrm{cased} \mathrm{off.}$ 
The caliper $\log$ (appendix 1, fig. 17) and borehole television survey show numerous minor fractures and several major fractures. The major horizontal fracture is at $172.5 \mathrm{ft}$ bls. Major vertical fractures are at 111-123 and 293-304 ft bls. The fluid-resistivity log shows changes in slope at approximately 112,180 , and $275 \mathrm{ft}$ bls, which coincide with fractures. The fluid-temperature log shows a large gradient, which does not indicate borehole flow.

\section{Vertical Distribution of Specific Capacity}

A straddle packer system was used to isolate selected intervals in the five exploratory boreholes and one offsite borehole (MG-1242) to obtain water-level, specific-capacity, and water-quality data. A water sample from each isolated interval was analyzed for VOC's. Small changes in water level above the upper packer or below the lower packer are caused by the pumping of nearby public-supply wells.

Tables 3,5, 7, 9, 11, and 13 present specific-capacity data for 27 intervals isolated in 6 boreholes. Specific capacity is not related to depth. Specific capacities greater than $1(\mathrm{gal} / \mathrm{min}) / \mathrm{ft}$ were evenly distributed in intervals isolated between the bottom of casing and $265 \mathrm{ft}$ bls: $87-115 \mathrm{ft} \mathrm{bls}[8.2(\mathrm{gal} / \mathrm{min}) / \mathrm{ft}], 126-143 \mathrm{ft} \mathrm{bls}[>5.7(\mathrm{gal} / \mathrm{min}) / \mathrm{ft}], 145-$ $177 \mathrm{ft}$ bls $[4.7(\mathrm{gal} / \mathrm{min}) / \mathrm{ft}], 204-235 \mathrm{ft}$ bls $[>7.9(\mathrm{gal} / \mathrm{min}) / \mathrm{ft}]$, and $237-265 \mathrm{ft} \mathrm{bls}$ $[8.7(\mathrm{gal} / \mathrm{min}) / \mathrm{ft}]$. Three of the isolated intervals with specific capacities greater than 1 (gal/min)/ft were identified by geophysical logging as water-receiving zones and one was identified as a water-producing zone. 


\section{BK-2511}

Six intervals were isolated in borehole BK-2511 (table 3). The interval from 187 to $215 \mathrm{ft}$ bls did not produce water. The specific capacity of the other intervals ranged from 0.01 to $0.04(\mathrm{gal} / \mathrm{min}) / \mathrm{ft}$. Data on water levels above the isolated zone, in the isolated zone, and below the isolated zone before the start of pumping and just before pumping stopped are summarized in table 4.

Table 3. Intervals isolated by straddle packers in borehole BK-2511,

Fischer and Porter Site, Warminster, Pa.

[(ga//min)/ft, gallons per minute per foot of drawdown; $\mu \mathrm{s} / \mathrm{cm}$, microsiemens per centimeter at 25 degrees Celsius; --, no data]

\begin{tabular}{cccccl}
\hline $\begin{array}{c}\text { Packer settings } \\
\text { (feet below } \\
\text { land surface) }\end{array}$ & $\begin{array}{c}\text { Pumping } \\
\text { time } \\
\text { (minutes) }\end{array}$ & $\begin{array}{c}\text { Volume } \\
\text { pumped } \\
\text { (gallons) }\end{array}$ & $\begin{array}{c}\text { Specific } \\
\text { capacity } \\
\text { [(gal/min)/tt] }\end{array}$ & $\begin{array}{c}\text { Specific } \\
\text { conductance } \\
\text { ( } \mu \mathrm{s} / \mathrm{cm})\end{array}$ & Remarks \\
\hline${ }^{1} 187$ & 186 & 1,260 & 0.2 & 500 & No water; no sample taken \\
$187-215$ & 12.5 & 37.5 & - & - & \\
$211-239$ & 96 & 120 & .01 & 480 & Pumped dry \\
$241-269$ & 24 & 110 & .04 & 485 & Pumped dry \\
$277-305$ & 32 & 100 & .03 & 480 & Pumped dry \\
2305 & 22.5 & 110 & .04 & 480 & \\
\hline
\end{tabular}

1 The lower packer was inflated, and water was purnped from above the lower packer. The upper packer was not inflated.

2 The upper packer was inflated, and water was pumped from below the upper packer. The lower packer was not inflated.

Table 4. Water levels before and at the end of aquifer-isolation tests of borehole BK-2511, Fischer and Porter Site, Warminster, Pa.

[--, packer not inflated]

\begin{tabular}{|c|c|c|c|c|c|c|}
\hline \multirow{2}{*}{$\begin{array}{l}\text { Packer settings } \\
\text { (feet below land } \\
\text { surface) }\end{array}$} & \multicolumn{3}{|c|}{$\begin{array}{l}\text { Depth to water before start of pumping } \\
\text { (feet below land surface) }\end{array}$} & \multicolumn{3}{|c|}{$\begin{array}{l}\text { Depth to water at end of pumping } \\
\text { (feet below land surface) }\end{array}$} \\
\hline & $\begin{array}{l}\text { Above upper } \\
\text { packer }\end{array}$ & $\begin{array}{l}\text { In isolated } \\
\text { zone }\end{array}$ & $\begin{array}{l}\text { Below lower } \\
\text { packer }\end{array}$ & $\begin{array}{l}\text { Above upper } \\
\text { packer }\end{array}$ & $\begin{array}{l}\text { In isolated } \\
\text { zone }\end{array}$ & $\begin{array}{l}\text { Below lower } \\
\text { packer }\end{array}$ \\
\hline${ }^{1} 187$ & - & 30.03 & ${ }^{2} 121.65$ & - & 62.93 & 84.53 \\
\hline $187-215$ & 29.16 & 27.56 & 30.18 & 30.31 & 156.96 & 30.61 \\
\hline $211-239$ & 28.80 & 28.36 & 30.84 & 30.39 & 151.46 & 31.73 \\
\hline 241-269 & 29.58 & 28.06 & 29.56 & 29.93 & 155.41 & 31.21 \\
\hline $277-305$ & 29.16 & 27.97 & 27.08 & 29.20 & 149.36 & 29.25 \\
\hline 3305 & 27.09 & 25.89 & - & 28.27 & 142.67 & - \\
\hline
\end{tabular}

1 The lower packer was inflated, and water was pumped from above the lower packer. The upper packer was not inflated.

${ }^{2}$ Water level not fully recovered from test of interval 187-215 feet below land surface.

${ }^{3}$ The upper packer was inflated, and water was pumped from below the upper packer. The lower packer was not inflated. 


\section{BK-2512}

Six intervals were isolated in borehole BK-2512 (table 5). Isolated intervals that included a water-producing or water-receiving fracture had the highest specific capacities. Specific capacities greater than $7.9(\mathrm{gal} / \mathrm{min}) / \mathrm{ft}$ were measured in the intervals above 115 , 204-235, and 237-265 ft bls. Fractures in these intervals are in fine-grained sandstone units. The interval above $115 \mathrm{ft}$ bls includes the water-producing fracture at $96 \mathrm{ft}$ bls. The interval 204-235 ft bls includes the water-receiving fracture at $217 \mathrm{ft}$ bls. The interval 237 $265 \mathrm{ft}$ bls includes a large, water-receiving, vertical fracture at 242-250 ft bls. The interval 132-160 ft bls includes the fracture at $148 \mathrm{ft}$ bls, which is a minor water-receiving fracture; specific capacity of this interval is $0.81(\mathrm{gal} / \mathrm{min}) / \mathrm{ft}$. The interval below $260 \mathrm{ft}$ bls, which included the highest yielding water-bearing zone in the borehole reported by the driller (greater than $50 \mathrm{gal} / \mathrm{min}$ at $280 \mathrm{ft}$ bls) had the second lowest specific capacity of the intervals isolated in borehole BK-2512, $0.03(\mathrm{gal} / \mathrm{min}) / \mathrm{ft}$. The specific conductance of water pumped from the receiving zones was higher than that of the water pumped from the producing zone (table 5), indicating that the water pumped from the receiving zones was not all the same water that flowed down the well bore from the producing zone. Data on water levels above the isolated zone, in the isolated zone, and below the isolated zone before the start of pumping and just before pumping stopped are summarized in table 6 .

Table 5. Intervals isolated by straddle packers in borehole BK-2512, Fischer and Porter Site, Warminster, Pa.

[(gal/min)/ft, gallon per minute per foot of drawdown; $\mu \mathrm{S} / \mathrm{cm}$, microsiemens per centimeter at 25 degrees Celsius; >, greater than]

\begin{tabular}{ccccc}
\hline $\begin{array}{c}\text { Packer settings } \\
\text { (feet below } \\
\text { land surface) }\end{array}$ & $\begin{array}{c}\text { Pumping } \\
\text { time } \\
\text { (minutes) }\end{array}$ & $\begin{array}{c}\text { Volume } \\
\text { pumped } \\
\text { (gallons) }\end{array}$ & $\begin{array}{c}\text { Specific capacity } \\
{[(\text { gal/min)/ft] }}\end{array}$ & $\begin{array}{c}\text { Specific } \\
\text { conductance } \\
\text { ( } \mu \text { S/cm) }\end{array}$ \\
\hline 115 & 94 & 799 & 8.2 & 420 \\
$132-160$ & 46 & 391 & .81 & 625 \\
$164-192$ & 75 & 110 & .01 & 520 \\
$204-235$ & 43 & 1,340 & $>7.9$ & 475 \\
$237-265$ & 49 & 275 & 8.7 & 475 \\
2265 & 67 & 268 & .03 & 560 \\
\hline
\end{tabular}

1 The lower packer was inflated, and water was pumped from above the lower packer. The upper packer was not inflated.

2 The upper packer was inflated, and water was pumped frombelow the upper packer. The lower packer was not inflated.

Table 6. Water levels before and at the end of aquifer-isolation tests of borehole BK-2512, Fischer and Porter Site, Warminster, Pa.

[--, packer not inflated]

\begin{tabular}{|c|c|c|c|c|c|c|}
\hline \multirow{2}{*}{$\begin{array}{l}\text { Packer settings } \\
\text { (feet below } \\
\text { land surface) }\end{array}$} & \multicolumn{3}{|c|}{$\begin{array}{l}\text { Depth to water before start of pumping } \\
\text { (feet below land surface) }\end{array}$} & \multicolumn{3}{|c|}{$\begin{array}{l}\text { Depth to water at end of pumping } \\
\text { (feet below land surface) }\end{array}$} \\
\hline & $\begin{array}{l}\text { Above upper } \\
\text { packer }\end{array}$ & $\begin{array}{l}\text { In isolated } \\
\text { zone }\end{array}$ & $\begin{array}{l}\text { Below lower } \\
\text { packer }\end{array}$ & $\begin{array}{l}\text { Above upper } \\
\text { packer }\end{array}$ & $\begin{array}{l}\text { In isolated } \\
\text { zone }\end{array}$ & $\begin{array}{c}\text { Below lower } \\
\text { packer }\end{array}$ \\
\hline 115 & - & 19.15 & 20.00 & $\cdots$ & 20.04 & 20.34 \\
\hline $132-160$ & 18.83 & 18.49 & 19.90 & 19.71 & 23.78 & 21.51 \\
\hline $162-192$ & 23.27 & 27.06 & 26.86 & 20.97 & 130.97 & 24.26 \\
\hline 204-235 & 23.77 & 24.38 & 27.69 & 22.31 & 27.49 & 24.54 \\
\hline $237-265$ & 23.24 & 24.00 & 24.86 & 23.82 & 24.47 & 25.12 \\
\hline${ }^{2} 265$ & 23.54 & 24.75 & - & 24.49 & 158.41 & - \\
\hline
\end{tabular}

1 The lower packer was inflated, and water was pumped from above the lower packer. The upper packer was not inflated.

2 The upper packer was inflated, and water was pumped from below the upper packer. The lower packer was not inflated. 


\section{BK-2513}

Six intervals were isolated in borehole BK-2513 (table 7). The interval isolated above $143 \mathrm{ft}$ bls, which included the highest yielding water-bearing zone in the borehole reported by the driller $(60 \mathrm{gal} / \mathrm{min}$ at $131 \mathrm{ft} \mathrm{bls})$, had the highest specific capacity of the intervals isolated in borehole BK-2513, which was greater than $5.7(\mathrm{gal} / \mathrm{min}) / \mathrm{ft}$. This water-bearing zone is in a very fine-grained sandstone unit. Specific capacities of the other isolated intervals tanged from 0.07 to $0.23(\mathrm{gal} / \mathrm{min}) / \mathrm{ft}$. Data on water levels above the isolated zone, in the isolated zone, and below the isolated zone before the start of pumping and just before pumping stopped are summarized in table 8 .

Table 7. Intervals isolated by straddle packers in borehole BK-2513,

Fischer and Porter Site, Warminster, Pa.

[(gal/min)/ft, gallon per minute per foot of drawdown; $\mu \mathrm{S} / \mathrm{cm}$, microsiemens per centimeter at 25 degrees Celsius; >, greater than]

\begin{tabular}{ccccc}
\hline $\begin{array}{c}\text { Packer settings } \\
\text { (feet below } \\
\text { land surface) }\end{array}$ & $\begin{array}{c}\text { Pumping } \\
\text { time } \\
\text { (minutes) }\end{array}$ & $\begin{array}{c}\text { Volume } \\
\text { pumped } \\
\text { (gallons) }\end{array}$ & $\begin{array}{c}\text { Specific capacity } \\
\text { [(gal/min)/tt] }\end{array}$ & $\begin{array}{c}\text { Specitic } \\
\text { conductance } \\
\text { ( } \mu \text { S/cm) }\end{array}$ \\
\hline${ }^{1} 143$ & 151 & 860 & $>5.7$ & 450 \\
$143-171$ & 57 & 275 & .14 & 470 \\
$176-204$ & 57 & 290 & .12 & 450 \\
$202-232$ & 74 & 275 & .23 & 435 \\
$232-260$ & 111 & 275 & .07 & 470 \\
2260 & 46 & 250 & .09 & 540 \\
\hline
\end{tabular}

1 The lower packer was inflated, and water was pumped from above the lower packer. The upper packer was not inflated.

2 The upper packer was inflated, and water was pumped from below the upper packer. The lower packer was not inflated.

Table 8. Water levels before and at the end of aquifer-isolation tests of borehole BK-2513, Fischer and Porter Site, Warminster, Pa.

[-, packer not inflated]

\begin{tabular}{|c|c|c|c|c|c|c|}
\hline \multirow{2}{*}{$\begin{array}{l}\text { Packer settings } \\
\text { (feet below } \\
\text { land surface) }\end{array}$} & \multicolumn{3}{|c|}{$\begin{array}{l}\text { Depth to water before start of pumping } \\
\text { (feet below land surface) }\end{array}$} & \multicolumn{3}{|c|}{$\begin{array}{l}\text { Depth to water at end of pumping } \\
\text { (feet below land surface) }\end{array}$} \\
\hline & $\begin{array}{l}\text { Above upper } \\
\text { packer }\end{array}$ & $\begin{array}{l}\text { In isolated } \\
\text { zone }\end{array}$ & $\begin{array}{l}\text { Below lower } \\
\text { packer }\end{array}$ & $\begin{array}{l}\text { Above upper } \\
\text { packer }\end{array}$ & $\begin{array}{l}\text { In isolated } \\
\text { zone }\end{array}$ & $\begin{array}{l}\text { Below lower } \\
\text { packer }\end{array}$ \\
\hline${ }^{1} 143$ & - & 38.50 & 38.32 & - & 38.55 & 38.29 \\
\hline 143-171 & 35.58 & 35.01 & 35.87 & 36.88 & 69.29 & 36.63 \\
\hline $176-204$ & 37.60 & 37.70 & 38.06 & 37.73 & 78.52 & 38.43 \\
\hline 202-232 & 36.84 & 37.09 & 36.90 & 35.98 & 53.18 & 37.15 \\
\hline $232-260$ & 38.01 & 38.50 & 38.43 & 38.11 & 73.78 & 38.62 \\
\hline${ }^{2} 260$ & 38.00 & 37.89 & - & 38.88 & 100.22 & - \\
\hline
\end{tabular}

1 The lower packer was inflated, and water was pumped from above the lower packer. The upper packer was not inflated.

2 The upper packer was inflated, and water was pumped from below the upper packer. The lower packer was not inflated. 


\section{BK-2514}

Seven intervals were isolated in borehole BK-2514 (table 9). Specific capacity ranged from $<0.03$ to 0.43 ( $\mathrm{gal} / \mathrm{min}$ ) $/ \mathrm{ft}$. Specific capacity could not be calculated for the interval 209-237 ft bls, which includes the water-receiving fracture at $225 \mathrm{ft}$ bls, because the transducer data were unreliable. The interval below $237 \mathrm{ft}$ bls, which includes the waterreceiving fractures at 225 and $250 \mathrm{ft}$ bls, had the highest specific capacity,

$0.43(\mathrm{gal} / \mathrm{min}) / \mathrm{ft}$, of the intervals isolated in borehole BK-2514. The interval above $58 \mathrm{ft}$ bls, which includes a water-producing fracture at $58 \mathrm{ft}$ bls that produced $8.3 \mathrm{gal} / \mathrm{min}$ during geophysical logging, had the lowest specific capacity of the intervals isolated in borehole BK-2514, $<0.03(\mathrm{gal} / \mathrm{min}) / \mathrm{ft}$. At the time of the aquifer-isolation test, the water level in the interval above $72 \mathrm{ft}$ bls was $58.58 \mathrm{ft}$ bls (table 10), indicating that this fracture had been partially or completely dewatered either by the natural seasonal decline in water level or drainage through the open borehole. The specific conductance of water in the receiving zones was higher than that of the water in the producing zone (table 9), indicating that water pumped from the receiving zones was not all the same water that flowed down the well bore from the producing zone.

Data on water levels above the isolated zone, in the isolated zone, and below the isolated zone before the start of pumping and just before pumping stopped are summarized in table 10. During the aquifer-isolation test of this borehole, a thunderstorm produced lightning that struck and destroyed the transducers and data logger. Measurements thereafter were made with electric measuring tapes.

Table 9. Intervals isolated by straddle packers in borehole BK-2514, Fischer and Porter Site, Warminster, Pa.

[(gal/min)/ft, gallon per minute per foot of drawdown; $\mu \mathrm{S} / \mathrm{cm}$, microsiemens per centimeter at 25 degrees Celsius; --, no data; <, less than]

\begin{tabular}{cccccc}
\hline $\begin{array}{c}\text { Packer settings } \\
\text { (feet below } \\
\text { land surface) }\end{array}$ & $\begin{array}{c}\text { Pumping } \\
\text { time } \\
\text { (minutes) }\end{array}$ & $\begin{array}{c}\text { Volume } \\
\text { pumped } \\
\text { (gallons) }\end{array}$ & $\begin{array}{c}\text { Specific } \\
\text { capacity } \\
{[(\text { gal/min)/ft] }}\end{array}$ & $\begin{array}{c}\text { Specific } \\
\text { conductance } \\
(\mu \mathrm{S} / \mathrm{cm})\end{array}$ & Remarks \\
\hline${ }^{1} 72$ & 100 & 110 & $<0.3$ & 500 & No water; no sample \\
$72-100$ & - & - & - & - & \\
$100-128$ & 44 & 26 & .03 & 620 & \\
$130-158$ & 29 & 75 & .05 & 570 & \\
$177-205$ & 50 & 270 & .06 & 580 & \\
$209-237$ & 68 & 350 & $(2)$ & 590 & 620 \\
3237 & 60 & 420 & .43 & 63 & \\
\hline
\end{tabular}

\footnotetext{
1 The lower packer was inflated, and water was pumped from above the lower packer.

The upper packer was not inflated.

2 Transducer data unreliable.

${ }^{3}$ The upper packer was inflated, and water was pumped from below the upper packer.

The lower packer was not inflated.
} 
Table 10. Water levels before and at the end of aquifer-isolation tests of borehole BK-2514, Fischer and Porter Site, Warminster, Pa.

[--, packer not inflated]

\begin{tabular}{|c|c|c|c|c|c|c|}
\hline \multirow{2}{*}{$\begin{array}{l}\text { Packer settings } \\
\text { (feet below } \\
\text { land surface) }\end{array}$} & \multicolumn{3}{|c|}{$\begin{array}{l}\text { Depth to water before start of pumping } \\
\text { (feet below land surface) }\end{array}$} & \multicolumn{3}{|c|}{$\begin{array}{l}\text { Depth to water at end of pumping } \\
\text { (feet below land surface) }\end{array}$} \\
\hline & $\begin{array}{l}\text { Above upper } \\
\text { packer }\end{array}$ & $\begin{array}{l}\text { In isolated } \\
\text { zone }\end{array}$ & $\begin{array}{c}\text { Below lower } \\
\text { packer }\end{array}$ & $\begin{array}{l}\text { Above upper } \\
\text { packer }\end{array}$ & $\begin{array}{l}\text { In isolated } \\
\text { zone }\end{array}$ & $\begin{array}{c}\text { Below lower } \\
\text { packer }\end{array}$ \\
\hline $\begin{array}{c}172 \\
72-100\end{array}$ & (2) & $\begin{array}{l}58.58 \\
(2)\end{array}$ & $\begin{array}{l}58.44 \\
\text { (2) }\end{array}$ & (2) & $\begin{array}{l}62.03 \\
(2)\end{array}$ & $\begin{array}{l}59.15 \\
\text { (2) }\end{array}$ \\
\hline $100-128$ & 59.41 & 57.27 & 65.89 & 58.68 & 71.48 & 65.27 \\
\hline $130-158$ & 59.36 & 59.49 & ${ }^{3} 65.67$ & 59.19 & 111.03 & 66.37 \\
\hline $177-205$ & 59.47 & 67.27 & 67.09 & 58.95 & 153.57 & 67.08 \\
\hline 209-237 & 62.10 & 57.50 & 60.79 & 62.07 & $\left({ }^{4}\right)$ & $(4)$ \\
\hline 5237 & 64.87 & 66.53 & - & 65.56 & 82.87 & - \\
\hline
\end{tabular}

1 The lower packer was inflated, and water was pumped from above the lower packer. The upper packer was not inflated.

2 No water in this interval.

3 Transducer data unreliable.

4 Transducers and data logger destroyed by lightning.

5 The upper packer was inflated, and water was pumped from below the upper packer.

The lower packer was not inflated.

\section{BK-2515}

Five intervals were isolated in borehole BK-2515 (table 11). Specific capacities ranged from 0.01 to $0.09(\mathrm{gal} / \mathrm{min}) / \mathrm{ft}$. Data on water levels above the isolated zone, in the isolated zone, and below the isolated zone before the start of pumping and just before pumping stopped are summarized in table 12.

Table 11. Intervals isolated by straddle packers in borehole BK-2515,

Fischer and Porter Site, Warminster, Pa.

[(gal/min)/ft, gallon per minute per foot of drawdown; $\mu \mathrm{S} / \mathrm{cm}$, microsiemens per centimeter at 25 degrees Celsius; --, no data]

\begin{tabular}{cccccc}
\hline $\begin{array}{c}\text { Packer settings } \\
\text { (feet below } \\
\text { land surface) }\end{array}$ & $\begin{array}{c}\text { Pumping } \\
\text { time } \\
\text { (minutes) }\end{array}$ & $\begin{array}{c}\text { Volume } \\
\text { pumped } \\
\text { (gallons) }\end{array}$ & $\begin{array}{c}\text { Specific capacity } \\
\text { [(gal/min)/ft] }\end{array}$ & $\begin{array}{c}\text { Specific } \\
\text { conductance } \\
(\mu \mathrm{S} / \mathrm{cm})\end{array}$ & Remarks \\
\hline${ }^{1} 172$ & 74 & 495 & 20.09 & 650 & Pumped dry \\
$172-200$ & 91 & 220 & .03 & 740 & \\
$202-230$ & 52.5 & 75 & - & - & No water; no sample \\
$249-277$ & 10 & 20 & - & - & No water; no sample \\
3277 & 72 & 302 & .05 & 620 & \\
\hline
\end{tabular}

\footnotetext{
1 The lower packer was inflated, and water was pumped from above the lower packer. The upper packer was not inflated.

2 Measurement after 48 minutes of pumping. Constriction in measurement tube prevented additional measurements.

3 The upper packer was inflated, and water was pumped from below the upper packer. The lower packer was not inflated.
} 
Table 12. Water levels before and at the end of aquifer-isolation tests of borehole BK-2515, Fischer and Porter Site, Warminster, Pa.

[--, packer not inflated]

\begin{tabular}{|c|c|c|c|c|c|c|}
\hline \multirow{2}{*}{$\begin{array}{l}\text { Packer settings } \\
\text { (feet below } \\
\text { land surface) }\end{array}$} & \multicolumn{3}{|c|}{$\begin{array}{l}\text { Depth to water before start of pumping } \\
\text { (feet below land surface) }\end{array}$} & \multicolumn{3}{|c|}{$\begin{array}{l}\text { Depth to water at end of pumping } \\
\text { (feet below land surface) }\end{array}$} \\
\hline & $\begin{array}{l}\text { Above upper } \\
\text { packer }\end{array}$ & $\begin{array}{l}\text { In isolated } \\
\text { zone }\end{array}$ & $\begin{array}{l}\text { Below lower } \\
\text { packer }\end{array}$ & $\begin{array}{l}\text { Above upper } \\
\text { packer }\end{array}$ & $\begin{array}{l}\text { In isolated } \\
\text { zone }\end{array}$ & $\begin{array}{l}\text { Below lower } \\
\text { packer }\end{array}$ \\
\hline${ }^{1} 172$ & - & 35.99 & 38.03 & - & 269.72 & $1_{38.20}$ \\
\hline $172-200$ & 35.33 & 35.94 & $\left({ }^{3}\right)$ & 36.90 & 105.35 & (3) \\
\hline $202-230$ & 35.37 & 34.91 & 33.83 & 36.86 & 163.10 & 28.37 \\
\hline $249-277$ & 36.33 & 34.33 & 31.00 & 36.69 & 156.42 & 32.00 \\
\hline${ }^{4} 277$ & 35.75 & 40.41 & - & 36.54 & 115.49 & - \\
\hline
\end{tabular}

1 The lower packer was inflated, and water was pumped from above the lower packer.

The upper packer was not inflated.

${ }^{2}$ Measurement after 48 minutes of pumping. Constriction in measurement tube prevented additional measurements.

${ }^{3}$ No data.

4 The upper packer was inflated, and water was pumped from below the upper packer.

The lower packer was not inflated.

\section{MG-1242}

Four intervals were isolated in borehole MG-1242 (table 13). Specific capacities ranged from 0.02 to 4.7 ( $\mathrm{gal} / \mathrm{min}$ )/ $\mathrm{ft}$. The interval below $145 \mathrm{ft}$ bls, which includes the waterreceiving fracture at $156 \mathrm{ft}$ bls, had the highest specific capacity, $4.7(\mathrm{gal} / \mathrm{min}) / \mathrm{ft}$, of the intervals isolated in borehole MG-1242. Data on water levels above the isolated zone, in the isolated zone, and below the isolated zone before the start of pumping and just before pumping stopped are summarized in table 14.

Table 13. Intervals isolated by straddle packers in borehole MG-1242, Hatboro, Pa.

[(gal/min)/ft, gallon per minute per foot of drawdown; $\mu \mathrm{S} / \mathrm{cm}$, microsiemens per centimeter at 25 degrees Celsius]

\begin{tabular}{ccccc}
\hline $\begin{array}{c}\text { Packer settings } \\
\text { (feet below } \\
\text { land surface) }\end{array}$ & $\begin{array}{c}\text { Pumping } \\
\text { time } \\
\text { (minutes) }\end{array}$ & $\begin{array}{c}\text { Volume } \\
\text { pumped } \\
\text { (gallons) }\end{array}$ & $\begin{array}{c}\text { Specific } \\
\text { capacity } \\
\text { [(gal/min)/ft] }\end{array}$ & $\begin{array}{c}\text { Specific } \\
\text { conductance } \\
\text { ( } \mu \text { S/cm) }\end{array}$ \\
\hline 190 & 59 & 220 & 0.14 & 640 \\
$90-115$ & 79 & 90 & .02 & 550 \\
$120-145$ & 27 & 70 & .03 & 700 \\
2145 & 41 & 141 & 4.7 & 740 \\
\hline
\end{tabular}

1 The lower packer was inflated, and water was pumped from above the lower packer. The upper packer was not inflated.

2 The upper packer was inflated, and water was pumped from below the upper packer. The lower packer was not inflated. 
Table 14. Water levels before and at the end of aquifer-isolation tests of borehole MG-1242, Hatboro, Pa.

[--, packer not inflated]

\begin{tabular}{|c|c|c|c|c|c|c|}
\hline \multirow{2}{*}{$\begin{array}{l}\text { Packer settings } \\
\text { (feet below } \\
\text { land surface) }\end{array}$} & \multicolumn{3}{|c|}{$\begin{array}{l}\text { Depth to water before start of pumping } \\
\text { (feet below land surface) }\end{array}$} & \multicolumn{3}{|c|}{$\begin{array}{l}\text { Depth to water at end of pumping } \\
\text { (feet below land surface) }\end{array}$} \\
\hline & $\begin{array}{c}\text { Above upper } \\
\text { packer }\end{array}$ & $\begin{array}{c}\text { In isolated } \\
\text { zone }\end{array}$ & $\begin{array}{c}\text { Below lower } \\
\text { packer }\end{array}$ & $\begin{array}{c}\text { Above upper } \\
\text { packer }\end{array}$ & $\begin{array}{l}\text { In isolated } \\
\text { zone }\end{array}$ & $\begin{array}{c}\text { Below lower } \\
\text { packer }\end{array}$ \\
\hline $1_{90}$ & - & 38.17 & (2) & - & 63.80 & (2) \\
\hline $90-115$ & 38.33 & 43.19 & (2) & 39.38 & 110.00 & (2) \\
\hline $120-145$ & 38.19 & 43.17 & (2) & 38.21 & 140.00 & (2) \\
\hline${ }^{3} 145$ & 36.74 & 43.42 & - & 36.74 & 44.15 & _ \\
\hline
\end{tabular}

1 The lower packer was inflated, and water was pumped from above the lower packer. The upper packer was not inflated.

2 No data.

${ }^{3}$ The upper packer was inflated, and water was pumped from below the upper packer.

The lower packer was not inflated.

\section{Water Levels}

Water levels at the Fischer and Porter Site were monitored to determine the effects of pumping of extraction wells in the Fischer and Porter treatment system and public-supply wells on water levels at the site. All 17 monitor wells on the Fischer and Porter Site (fig. 2) were equipped with continuous water-level recorders. The graphical charts recorded aquifer response to pumping, precipitation, and seasonal water-level trends. Plate 3 shows the generalized stratigraphy, which was based on analysis of borehole geophysical logs, and the vertical location of the well screens for each monitor well cluster. The wells used for water-level monitoring, the screened intervals, and the effect of pumping of the Fisher and Porter treatment system wells and public-supply wells are listed in table 15. Hydrographs from the monitor wells are in appendix 4.

The Fischer and Porter treatment system uses recovery wells BK-370, BK-371, and BK-1324 (fig. 2), which are continuously pumped at a combined rate of $75 \mathrm{gal} / \mathrm{min}$. To determine the effect of pumping these wells on water levels, the recovery wells were shut down for 3 days and then turned back on. The recovery of water levels during the shutdown was used to assess the effect of pumping the treatment system wells on water levels in the monitor wells. In some cases, no recovery took place, and the slowing or halt in the natural water-level recession was used to estimate the effect of pumping the treatment system wells. Where water levels are greatly influenced by pumping of publicsupply wells, the change in the daily peaks or lows was used to determine the effect of pumping the treatment system wells.

To determine the potential effect of pumping unused public-supply well MG-946 (H16), the Hatboro Municipal Authority pumped well MG-946 at approximately $350 \mathrm{gal} / \mathrm{min}$ during January 5-7, 1994. During this time, monitor wells BK-1731, BK-1795, BK-1796, BK-2512, BK-2521, BK-2527, and BK-2528 along the western side of the Fischer and Porter Site were equipped with water-level recorders. The pumping of well MG-946 did not cause a measurable effect on water levels at the Fischer and Porter Site.

In general, water levels fluctuate in response to recharge to the ground-water system from precipitation and discharge from the ground-water system to pumping wells, ground-water evapotranspiration, and streams. Water levels generally rise during the late fall, winter, and early spring when ground-water evapotranspiration and soil-moisture 
evapotranspiration is at a minimum and recharge is at a maximum. Water levels generally decline during the late spring, summer, and early fall when ground-water evapotranspiration and soil-moisture evapotranspiration are at maximum and recharge is at a minimum.

Water levels in some wells at the Fischer and Porter Site are greatly affected by the pumping of Warminster Heights Development Corporation supply wells BK-366 and BK-367. Well BK-366 is open from 40 to $300 \mathrm{ft}$ bls and penetrates units 1 to 5 (pl. 3). Well BK-367 is open from 56 to $300 \mathrm{ft}$ bls and penetrates units 5 to 8 (pl. 3).

Hydrographs of the water level in public-supply well MG-947 (H-17) were obtained from the Hatboro Municipal Authority for selected time periods. The pumping pattern of well MG-947 was compared with water-level hydrographs from wells on the Fischer and Porter Site. Water-level fluctuations measured in wells at the Fischer and Porter Site did not match the pumping pattern of well MG-947, indicating no hydraulic connection.

Table 15. Changes in water level caused by pumping of public-supply wells and the shutdown of the Fischer and Porter treatment system wells, Fischer and Porter Site, Warminster, Pa.

[e, estimated]

\begin{tabular}{|c|c|c|c|c|}
\hline $\begin{array}{l}\text { U.S. Geological } \\
\text { Survey } \\
\text { identification } \\
\text { number }\end{array}$ & $\begin{array}{l}\text { Screened or } \\
\text { open interval } \\
\text { (feet below } \\
\text { land surface) }\end{array}$ & $\begin{array}{l}\text { Approximate daily } \\
\text { change in water } \\
\text { level caused by } \\
\text { pumping of public- } \\
\text { supply wells (feet) }\end{array}$ & $\begin{array}{l}\text { Dale of shutdown } \\
\text { of Fischer and Porter } \\
\text { treatment system wells }\end{array}$ & $\begin{array}{c}\text { Rise in water } \\
\text { level caused by } \\
\text { shutdown of the } \\
\text { Fischer and Porter } \\
\text { treatment system } \\
\text { wells (feet) }\end{array}$ \\
\hline BK-1731 & $47-65$ & 0.1 & December 13-15, 1993 & $0.2 \mathrm{e}$ \\
\hline BK-1793 & $23-40$ & ${ }^{1} .3$ & November 17-19, 1993 & ${ }^{1} .5 \mathrm{e}$ \\
\hline BK-1795 & 23-31 & .0 & $\begin{array}{l}\text { December 13-15, } 1993 \\
\text { May 16-19, } 1994\end{array}$ & $\begin{array}{l}.2 \mathrm{e} \\
.4 \mathrm{e}\end{array}$ \\
\hline BK-1796 & 78-146 & .5 & December 13-15, 1993 & 2.8 \\
\hline BK-2511 & $300-325$ & .7 & December 13-15, 1993 & 5.9 \\
\hline BK-2512 & $237-257$ & 5.3 & May $16-19,1994$ & 2.2 \\
\hline BK-2513 & $255-275$ & 2.3 & November 17-19, 1993 & 3.1 \\
\hline BK-2514 & $217-252$ & 2.8 & May 16-19, 1994 & .8 \\
\hline BK-2515 & 285-305 & .9 & December 13-15, 1993 & 6.3 \\
\hline BK-2521 & $190-210$ & 3.6 & December 13-15, 1993 & 4.3 \\
\hline BK-2522 & $132-157$ & 2.0 & April 27-29, 1994 & $.1 \mathrm{e}$ \\
\hline BK-2523 & $23.5-43.5$ & 1.7 & April 27-29, 1994 & $.1 \mathrm{e}$ \\
\hline BK-2524 & $115-135$ & 5.3 & November 17-19, 1993 & 1.1 \\
\hline BK-2525 & $31-51$ & .0 & April 27-29, 1994 & .0 \\
\hline BK-2526 & $50-70$ & .0 & $\begin{array}{l}\text { May } 16-19,1994 \\
\text { April 27-29, } 1994\end{array}$ & $\begin{array}{l}.9 \mathrm{e} \\
.0 \mathrm{e}\end{array}$ \\
\hline BK-2527 & $157-187$ & 2.6 & December 13-15, 1993 & 3.3 \\
\hline BK-2528 & $25-45$ & .1 & December 13-15, 1993 & $.4 \mathrm{e}$ \\
\hline
\end{tabular}

1 Change in fluid level. 


\section{Water Levels at Monitor Well Clusters and Boreholes}

BK-2511, BK-2521, and BK-1731-Well BK-2511 is screened from 300 to $325 \mathrm{ft}$ bls in unit 6 (pl. 3). Well BK-2511 was monitored during December 3-20, 1993 (appendix 4, fig. 1); the range in water-level fluctuation was $14.9 \mathrm{ft}$. The water level is affected by the pumping of a public-supply well, probably BK-367; the daily fluctuation caused by pumping is about $0.7 \mathrm{ft}$. The effect of pumping can be seen in the hydrograph, but the pumping cycle is not discernible. The shutdown of the Fischer and Porter treatment system wells during December 13-15 caused a rise in water level of $5.9 \mathrm{ft}$.

Well BK-2521 is screened from 190 to $210 \mathrm{ft}$ bls in unit 3 (pl. 3). Well BK-2521 was monitored during December 6, 1993, to January 14, 1994 (appendix 4, figs. 2 and 3). The range in water-level fluctuation during December 6-20 was $8.0 \mathrm{ft}$, and the range in waterlevel fluctuation during December 20 to January 14 was $16.5 \mathrm{ft}$. The water level is affected by the pumping of public-supply well BK-366, which is open to unit 3; the daily fluctuation caused by pumping is about $3.6 \mathrm{ft}$. The pumping cycle of well BK-366 can be clearly seen in the hydrograph. The shutdown of the Fischer and Porter treatment system wells during December 13-15 caused a rise in water level of $4.3 \mathrm{ft}$.

Borehole BK-1731 is open from 47 to $65 \mathrm{ft}$ bls in unit 1 (pl. 3). Borehole BK-1731 was monitored during December 3, 1993, to January 13, 1994 (appendix 4, figs. 4 and 5); the range in water-level fluctuation was $5.5 \mathrm{ft}$. The water level is slightly affected by the pumping of public-supply well BK-366; the daily fluctuation caused by pumping is approximately $0.1 \mathrm{ft}$. The effect of pumping can be seen in the hydrograph, but the pumping cycle is not discernible. The shutdown of the Fischer and Porter treatment system wells during December 13-15 caused a slowing of the natural water-level recession; it is equivalent to a rise in water level of approximately $0.2 \mathrm{ft}$.

Water levels measured in this cluster on December 13, 1993 (table 16), indicate a downward head gradient.

Table 16. Water-level measurements, December 13, 1993, and May 3, 1994, Fischer and Porter Site, Warminster, Pa.

\begin{tabular}{|c|c|c|c|c|c|}
\hline \multirow[b]{2}{*}{$\begin{array}{l}\text { Well or } \\
\text { borehole } \\
\text { number }\end{array}$} & \multirow[b]{2}{*}{$\begin{array}{c}\text { Land surface } \\
\text { elevation } \\
\text { (feet above } \\
\text { sea level) }\end{array}$} & \multicolumn{2}{|c|}{ December 13, 1993} & \multicolumn{2}{|c|}{ May 3, 1994} \\
\hline & & $\begin{array}{c}\text { Depth to } \\
\text { water below } \\
\text { land surface } \\
\text { (feet) }\end{array}$ & $\begin{array}{c}\text { Water level } \\
\text { (feet above } \\
\text { sea level) }\end{array}$ & $\begin{array}{c}\text { Depth to } \\
\text { water below } \\
\text { land surface } \\
\text { (feet) }\end{array}$ & $\begin{array}{c}\text { Water level } \\
\text { (feet above } \\
\text { sea level) }\end{array}$ \\
\hline BK-1731 & 282.71 & 12.08 & 270.63 & 13.18 & 269.53 \\
\hline${ }^{1}$ BK-1793 & 294.90 & 20.56 & 274.34 & 22.48 & 272.42 \\
\hline BK-1795 & 302.52 & 21.03 & 281.49 & 26.47 & 276.05 \\
\hline BK-1796 & 302.48 & 35.24 & 267.24 & 37.72 & 264.76 \\
\hline BK-2511 & 281.38 & 22.42 & 258.96 & 20.58 & 260.80 \\
\hline BK-2512 & 271.16 & 10.26 & 260.90 & 10.00 & 261.16 \\
\hline BK-2513 & 285.37 & 22.92 & 262.45 & 22.28 & 263.09 \\
\hline BK-2514 & 314.67 & 52.94 & 261.73 & 51.10 & 263.57 \\
\hline BK-2515 & 291.50 & 35.63 & 255.87 & 30.92 & 260.58 \\
\hline BK-2521 & 281.99 & 17.22 & 264.77 & 19.14 & 262.85 \\
\hline BK-2522 & 271.62 & 10.34 & 261.28 & 9.98 & 261.64 \\
\hline BK-2523 & 271.21 & 9.65 & 261.56 & 10.13 & 261.08 \\
\hline BK-2524 & 285.13 & 22.70 & 262.43 & 22.06 & 263.07 \\
\hline BK-2525 & 285.41 & 11.34 & 274.07 & 13.32 & 272.09 \\
\hline BK-2526 & 315.40 & 35.66 & 279.74 & 38.32 & 277.08 \\
\hline BK-2527 & 292.26 & 27.84 & 264.42 & 29.94 & 262.32 \\
\hline BK-2528 & 292.92 & 20.03 & 272.89 & 22.46 & 270.46 \\
\hline
\end{tabular}

1 Measurements represent level of top of free product floating on water surface. 
BK-2515, BK-2527, and BK-2528-Well BK-2515 is screened from 285 to $305 \mathrm{ft}$ bls in unit 6 (pl. 3). Well BK-2515 was monitored during December 8, 1993, to January 13, 1994 (appendix 4, figs. 6 and 7); the range in water-level fluctuation was $13.5 \mathrm{ft}$. The water level is affected by the pumping of a public-supply well, probably BK-367, which is open to unit 6; the daily fluctuation caused by pumping is about $0.9 \mathrm{ft}$. The effect of pumping can be seen in the hydrograph, but the pumping cycle is not discernible. The shutdown of the Fischer and Porter treatment system wells during December 13-15 caused a rise in water level of $6.3 \mathrm{ft}$.

Well BK-2527 is screened from 157 to $187 \mathrm{ft}$ bls in unit 3 (pl. 3). Well BK-2527 was monitored during December 7, 1993, to January 13, 1994 (appendix 4, figs. 8 and 9); the range in water-level fluctuation was $16.9 \mathrm{ft}$. The water level is affected by the pumping of public-supply well BK-366; the daily fluctuation caused by pumping is about $2.6 \mathrm{ft}$. The pumping cycles can be clearly seen in the hydrograph. The shutdown of the Fischer and Porter treatment system wells during December 13-15 caused a rise in water level of $3.3 \mathrm{ft}$.

Well BK-2528 is screened from 25 to $45 \mathrm{ft}$ bls in unit 1 (pl. 3). Well BK-2528 was monitored during December 7, 1993, to January 13, 1994 (appendix 4, figs. 10 and 11); the range in water-level fluctuation was $7.6 \mathrm{ft}$. The water level is slightly affected by the pumping of a public-supply well; the daily fluctuation caused by pumping is approximately $0.1 \mathrm{ft}$. The effect of pumping can be seen in the hydrograph, but the pumping cycle is not discernible. The shutdown of the Fischer and Porter treatment system wells during December 13-15 caused a slowing of the natural water-level recession equivalent to a rise in water level of approximately $0.4 \mathrm{ft}$.

Water levels measured in this well cluster on December 13, 1993 (table 16), indicate a downward head gradient.

BK-1795 and BK-1796-Borehole BK-1795 is open from 23 to $31 \mathrm{ft} \mathrm{bls} \mathrm{in} \mathrm{unit} 2$ (pl. 3). Borehole BK-1795 was monitored during December 6, 1993, to January 21, 1994 (appendix 4, figs. 12 and 13); the range in water-level fluctuation was $8.2 \mathrm{ft}$. The water level in BK-1795 does not appear to be affected by the pumping of public-supply wells. The shutdown of the Fischer and Porter treatment system wells during December 13-15 caused a slowing of the water-level recession equivalent to a rise in water level of approximately $0.2 \mathrm{ft}$. Borehole BK-1795 also was monitored during May 9-23, 1994 (appendix 4, fig. 14). The shutdown of the Fischer and Porter treatment system wells during May 16-19 caused a rise in water level of $0.4 \mathrm{ft}$.

Borehole BK-1796 is open from 78 to $146 \mathrm{ft}$ bls in unit 3 (pl. 3). Borehole BK-1796 was monitored during December 8, 1993, to January 13, 1994 (appendix 4, figs. 15 and 16); the range in water-level fluctuation was $14.5 \mathrm{ft}$. The water level is affected by the pumping of public-supply well BK-366, which is open to unit 3; the daily fluctuation caused by pumping is about $0.5 \mathrm{ft}$. The effect of pumping can be seen in the hydrograph, but the pumping cycle is not discernible. The shutdown of the Fischer and Porter treatment system wells during December 13-15 caused a rise in water level of $2.8 \mathrm{ft}$.

Water levels measured in this pair of boreholes on December 13, 1993 (table 16), indicate a downward head gradient.

BK-2514 and BK-2526-Well BK-2514 is screened from 217 to $252 \mathrm{ft}$ bls in unit 8 (pl. 3). Well BK-2514 was monitored during May 9-23, 1994 (appendix 4, fig. 17); the range in water-level fluctuation was $6.7 \mathrm{ft}$. The spike in the hydrograph on May 12 was caused by surface runoff infiltrating the well. The water level is affected by the pumping of publicsupply well BK-367, which is open to unit 8; the daily fluctuation caused by pumping is 
about $2.8 \mathrm{ft}$. The pumping cycle of well BK-367 can be clearly seen in the hydrograph. The shutdown of the Fischer and Porter treatment system wells during May 16-19 caused a rise in water level of about $0.8 \mathrm{ft}$.

Well BK-2526 is screened from 50 to $70 \mathrm{ft}$ bls in unit 4 (pl. 3). Well BK-2526 was monitored during April 12 to May 23, 1994 (appendix 4, figs. 18 and 19). The spikes in the hydrograph were caused by surface runoff infiltrating the well. The range in water-level fluctuation was $7.4 \mathrm{ft}$ during April 12 to May 9, $3.5 \mathrm{ft}$ during May 9-23, and $10.7 \mathrm{ft}$ during April 14 to May 23. The water level is not affected by the pumping of public-supply wells. The shutdown of the Fischer and Porter treatment system wells during April 27-29 did not affect the water level in well BK-2526; however, the shutdown of the Fischer and Porter treatment system wells during May 16-19 caused a halt in the natural water-level recession equivalent to a rise in water level of approximately $0.9 \mathrm{ft}$.

Water levels measured in this pair of wells on May 3, 1994 (table 16), indicate a downward head gradient.

BK-1793-Borehole BK-1793 is open from 23 to $40 \mathrm{ft}$ bls in unit 3 (pl. 3). Borehole BK-1793 was monitored during November 4 to December 6, 1993 (appendix 4, fig. 20). The depth to the top of free product floating on the water surface was measured. The range in fluid-level fluctuation during that time was $9.3 \mathrm{ft}$. The fluid level is affected by the pumping of public-supply well BK-366, which is open to unit 3; the daily fluctuation caused by pumping is about $0.3 \mathrm{ft}$. The effect of pumping can be seen in the hydrograph, but the pumping cycle is not discernible. The shutdown of the Fischer and Porter treatment system wells during November 17-19 caused a halt in the fluid-level recession equivalent to a rise in fluid level of approximately $0.5 \mathrm{ft}$.

BK-2513, BK-2524, and BK-2525-Well BK-2513 is screened from 255 to $275 \mathrm{ft}$ bls in unit 6 (pl. 3). Well BK-2513 was monitored during November 5 to December 7, 1993 (appendix 4, fig. 21); the range in water-level fluctuation was $10.5 \mathrm{ft}$. The water level is affected by the pumping of public-supply well BK-366; the daily fluctuation caused by pumping is about $2.3 \mathrm{ft}$. The pumping cycle of well BK-366 can be clearly seen in the hydrograph. The shutdown of the Fischer and Porter treatment system wells during November 17-19 caused a rise in water level of $3.1 \mathrm{ft}$.

Well BK-2524 is screened from 115 to $135 \mathrm{ft}$ bls in unit 3 (pl. 3). Well BK-2524 was monitored during November 8 to December 8, 1993 (appendix 4, fig. 22); the range in water-level fluctuation was $14.3 \mathrm{ft}$. The water level is affected by the pumping of publicsupply well BK-366, which is open to unit 3; the daily fluctuation caused by pumping is about $5.3 \mathrm{ft}$. The pumping cycle of well BK-366 can be clearly seen in the hydrograph. The shutdown of the Fischer and Porter treatment system wells during November 17-19 caused a rise in water level of $1.1 \mathrm{ft}$.

Well BK-2525 is screened from 31 to $51 \mathrm{ft}$ bls in the top of unit 2 (pl. 3). Well BK-2525 was monitored during April 20 to May 9, 1994 (appendix 4, fig. 23); the range in waterlevel fluctuation was $3.2 \mathrm{ft}$. The water level is not affected by the pumping of publicsupply wells. The shutdown of the Fischer and Porter treatment system wells during April 27-29 did not cause a measurable effect on the water level in well BK-2525.

Water levels measured in this cluster on December 13, 1993 (table 16), indicate a downward head gradient from the shallow to the intermediate and deep zones.

BK-2512, BK-2522, and BK-2523-Well BK-2512 is screened from 237 to $257 \mathrm{ft}$ bls in unit 5 (pl. 3). Well BK-2512 was monitored during May 3-19, 1994 (appendix 4, fig. 24-26); the range in water-level fluctuation was $8.5 \mathrm{ft}$. The water level is greatly affected by the pumping of public-supply well BK-366, which is open to unit 5; the daily fluctuation 
caused by pumping is about $5.3 \mathrm{ft}$. The pumping cycle of well BK-366 can be clearly seen in the hydrograph. The shutdown of the Fischer and Porter treatment system wells during May 16-19 caused a rise in water level of $2.2 \mathrm{ft}$.

Well BK-2522 is screened from 132 to $157 \mathrm{ft}$ bls in the bottom of unit 2 and the top of unit 3 (pl. 3). Well BK-2522 was monitored during April 14 to May 9, 1994 (appendix 4, fig. 27); the range in water-level fluctuation was $5.1 \mathrm{ft}$. The water level is affected by the pumping of public-supply well BK-366, which is open to units 2 and 3; the daily fluctuation caused by pumping is about $2.0 \mathrm{ft}$. The pumping cycle of well BK-366 can be clearly seen in the hydrograph. It is difficult to determine the effect of the shutdown of the Fischer and Porter treatment system wells during April 27-29; the shutdown appears to have caused a rise in water level of about $0.1 \mathrm{ft}$.

Well BK-2523 is screened from 23.5 to $43.5 \mathrm{ft}$ bls above unit 1 (pl. 3). Well BK-2523 was monitored during April 11 to May 9, 1994 (appendix 4, fig. 28); the range in water-level fluctuation was $3.7 \mathrm{ft}$. The water level is affected by the pumping of public-supply well BK-366, which is open to unit 1; the daily fluctuation caused by pumping is approximately $1.7 \mathrm{ft}$. The pumping cycle of well BK-366 can be clearly seen in the hydrograph. Well BK-2523 is the only shallow well in which a pumping cycle can be seen. The shutdown of the Fischer and Porter treatment system wells during April 27-29 caused a rise in water level of approximately $0.1 \mathrm{ft}$.

Water levels measured in this cluster on December 13, 1993, and May 3, 1994, were within 0.66 and $0.56 \mathrm{ft}$, respectively (table 16). The December 13, 1993, measurements indicate a slight downward head gradient.

\section{Effect of Pumping the Fischer and Porter Treatment System Wells on Water Levels}

The shutdown of the Fischer and Porter treatment system wells had only a small effect on water levels in the shallow zone. Estimated rises in water level were less than $1 \mathrm{ft}$. The shutdown did not cause a measurable effect on the water level in shallow well BK-2525. The shutdown of the Fischer and Porter treatment system wells caused a rise in water level in all wells screened in the intermediate and deep zones. These wells are located around the boundary of the Fischer and Porter property. The rise in water level was as great as $4.3 \mathrm{ft}$ (well BK-2521) in the intermediate zone (fig. 12) and as great as $6.9 \mathrm{ft}$ (well BK-2511) in the deep zone (fig. 13). 


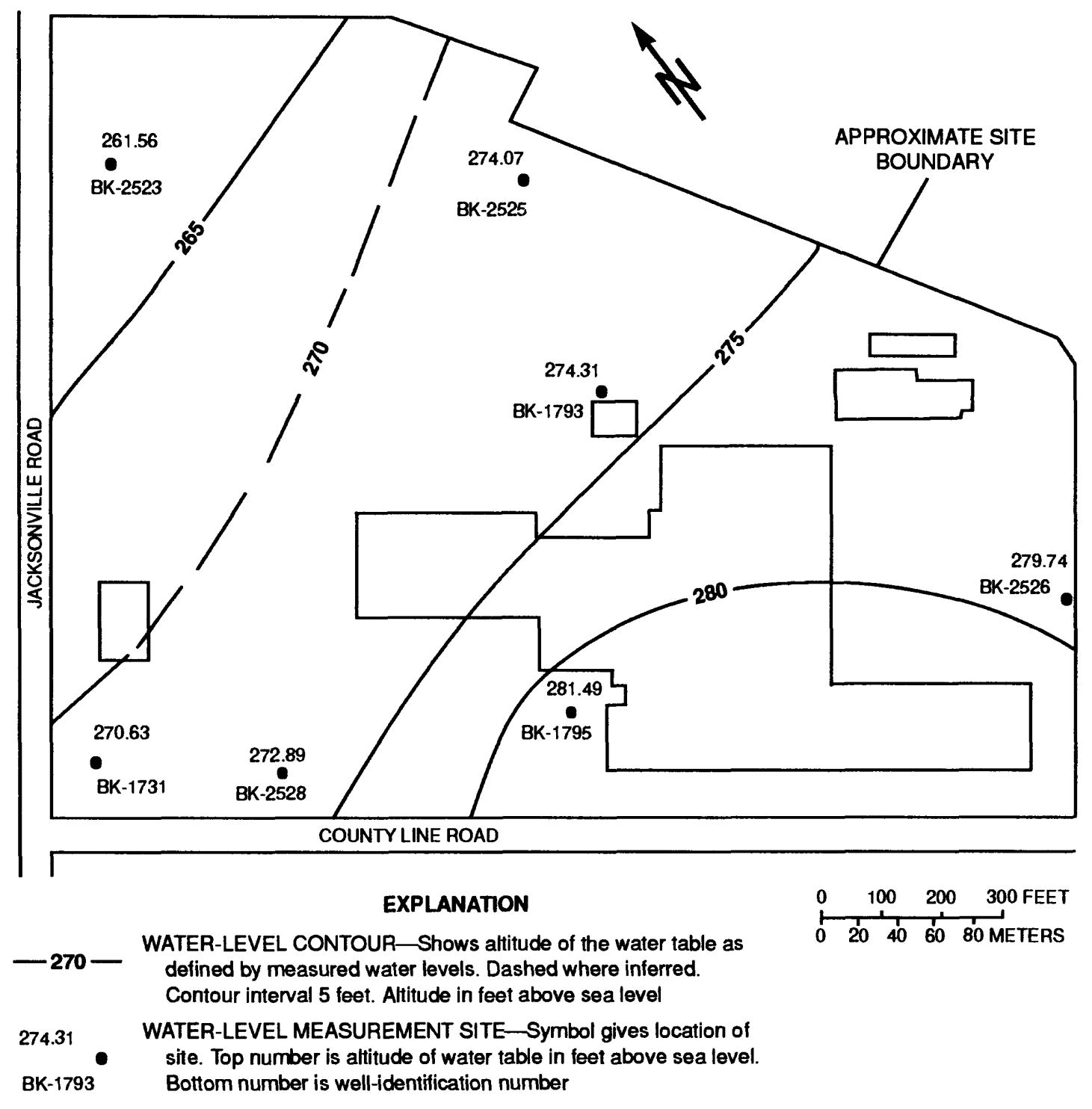

Figure 12. Water-level contour map for wells screened in the shallow zone, Fischer and Porter Site, Warminster, Pa., December 13, 1993. 


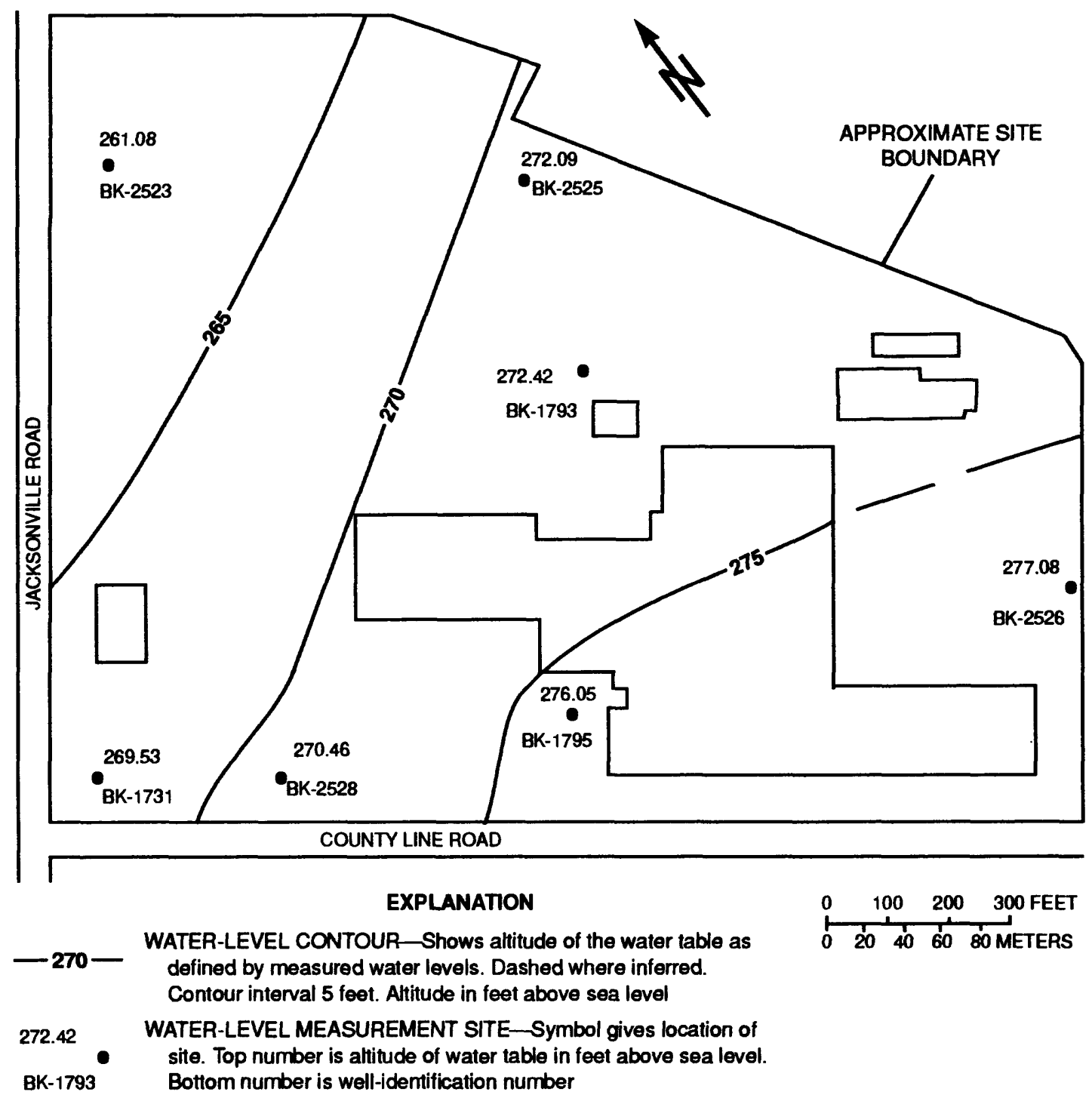

Figure 13. Water-level contour map for wells screened in the shallow zone, Fischer and Porter Site, Warminster, Pa., May 3, 1994. 


\section{Synoptic Water-Level Measurements}

All of the monitor wells at the Fischer and Porter Site were measured on December 13, 1993, and May 3, 1994, while the extraction wells were pumping. Measurements are listed in table 16, and water-level contours are shown on figures 14-17. Water levels were plotted by the depth interval (shallow, intermediate, or deep) at which each well is screened or open. Shallow wells and boreholes (BK-1731, BK-1793, BK-1795, BK-2523, BK-2525, $B K-2526$, and BK-2528) are those that are screened or open between 23 and $70 \mathrm{ft}$ bls. Intermediate-depth wells and boreholes (BK-1796, BK-2521, BK-2522, BK-2524, and $B K-2527)$ are those that are screened or open between 78 and $210 \mathrm{ft}$ bls. Deep wells (BK-2511, BK-2512, BK-2513, BK-2514, and BK-2515) are those that are screened between 217 and $325 \mathrm{ft}$ bls. Water levels were plotted on the basis of depth of well screen or open interval because the response of water levels to stress generally is more related to the depth of the stratigraphic unit that a well is screened in than to which particular stratigraphic unit the well is screened in. Water levels in wells screened in the same depth interval are contourable. For example, the response of water levels to pumping in wells screened or open to unit 3 depends on the depth of unit 3 at the well location. If unit 3 is near the land surface, the response of water levels in wells screened in it at this depth is similar to the response observed in other shallow wells. If unit 3 is between 217 and $335 \mathrm{ft}$ bls, the response of water levels in wells screened in it at this depth is similar to the response observed in other deep wells. Water levels measured in all wells screened in unit 3 are not contourable. Wells in the Fischer and Porter treatment system were not measured because they are open-hole construction, and water levels measured in these wells represent a composite of all water-bearing zones penetrated by the well. Extraction well BK-1324 is not measurable because of the oil skimming system installed in the well.

Water-level contours for December 13, 1993, and May 3, 1994, for the shallow zone are shown in figures 14 and 15. The maximum water-level-altitude difference was $19.9 \mathrm{ft}$ on December 13 and $16.0 \mathrm{ft}$ on May 3. The direction of ground-water flow, which is perpendicular to the water-level contours, is toward the north. Discharge is to the unnamed tributary to Pennypack Creek north of the Fischer and Porter Site.

Water-level contours for December 13, 1993, and May 3, 1994, for the intermediatedepth zone are shown in figures 16 and 17 . The maximum water-level-altitude difference was $5.9 \mathrm{ft}$ on December 13 and $3.2 \mathrm{ft}$ on May 3. The direction of ground-water flow, which is perpendicular to the water-level contours, is toward the north. Discharge probably is to the unnamed tributary to Pennypack Creek north of the Fischer and Porter Site.

Water-level contours for December 13,1993, and May 3, 1994, for wells screened in the deep zone are shown in figures 18 and 19. The maximum water-level-altitude difference was $6.6 \mathrm{ft}$ on December 13 and $3.0 \mathrm{ft}$ on May 3. The direction of ground-water flow, which is perpendicular to the water-level contours, was toward the west-southwest on December 13 and toward the west on May 3. Discharge probably is to the unnamed tributary to Pennypack Creek west of the Fischer and Porter Site. 


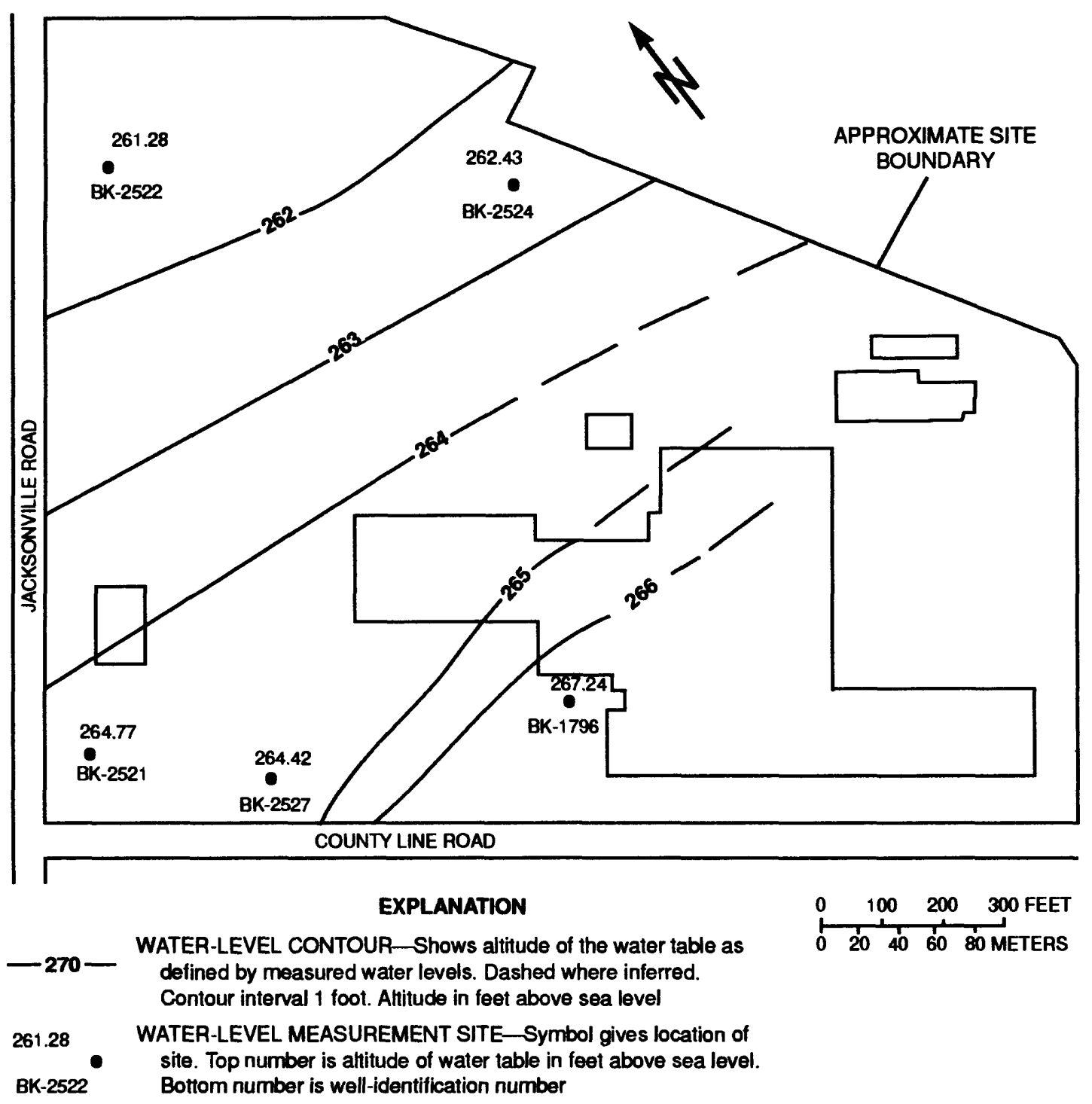

Figure 14. Water-level contour map for wells screened in the intermediate zone, Fischer and Porter Site, Warminster, Pa., December 13, 1993. 


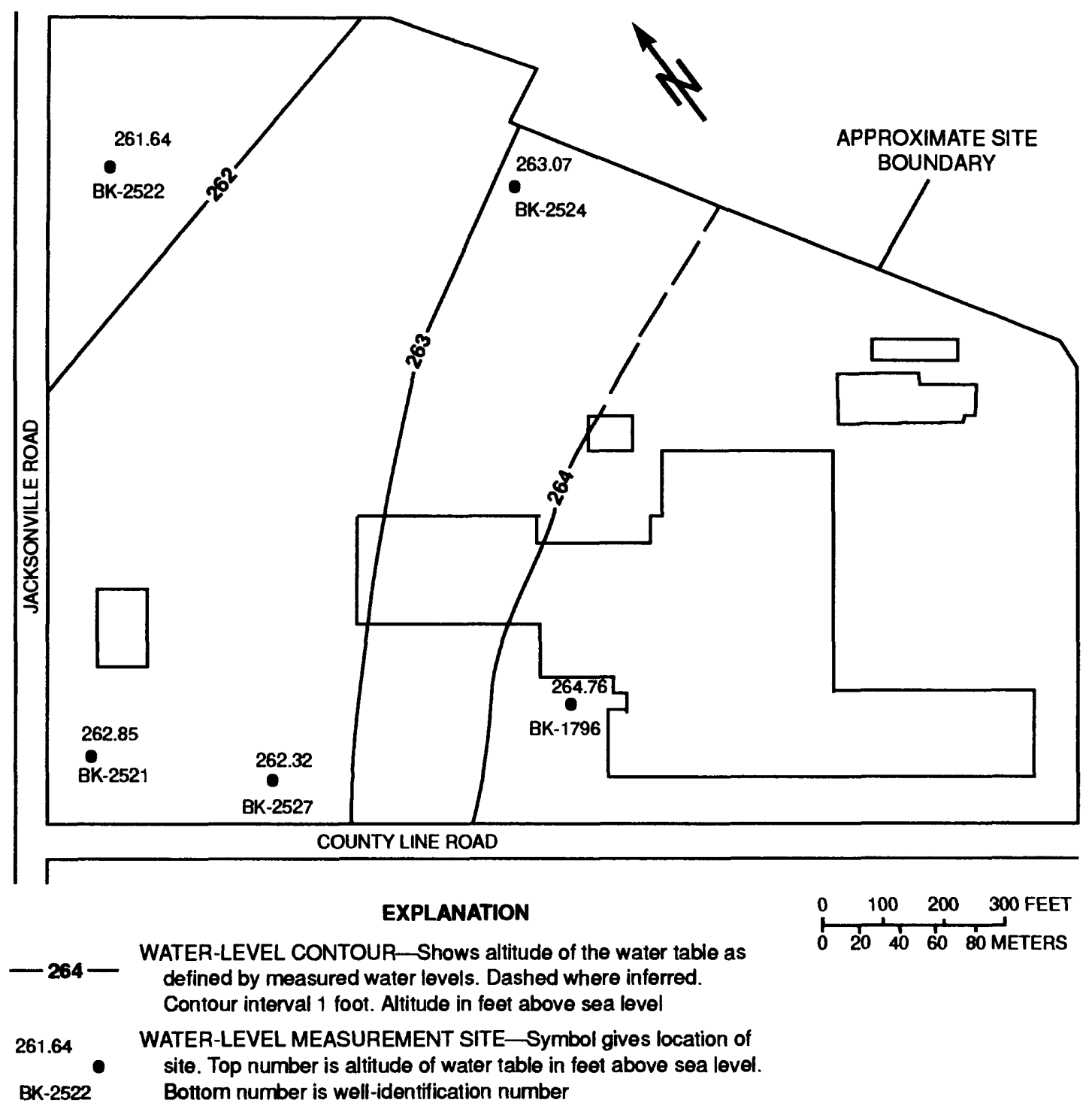

Figure 15. Water-level contour map for wells screened in the intermediate zone, Fischer and Porter Site, Warminster, Pa., May 3, 1994. 


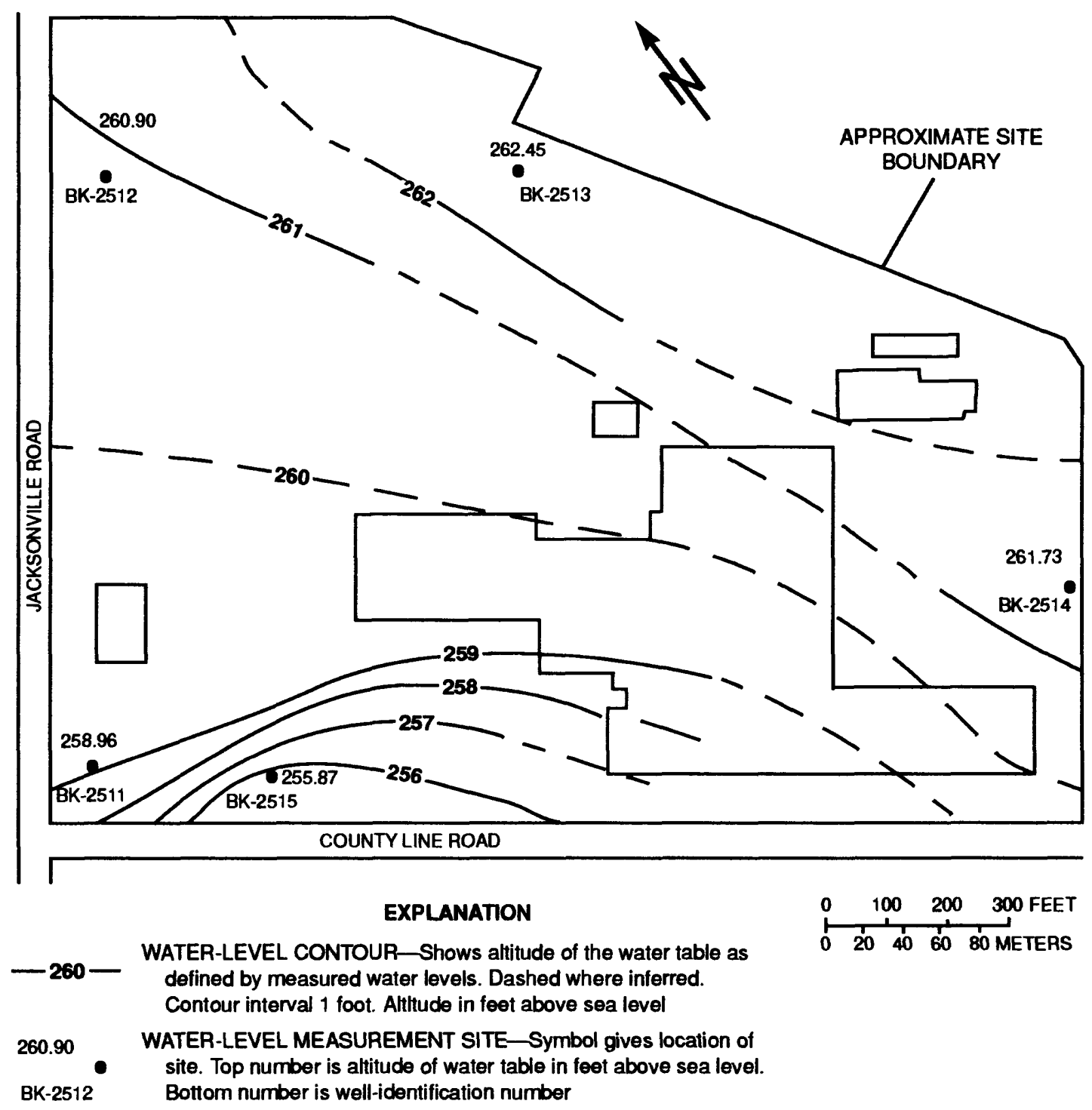

Figure 16. Water-level contour map for wells screened in the deep zone, Fischer and Porter Site, Warminster, Pa., December 13, 1993. 


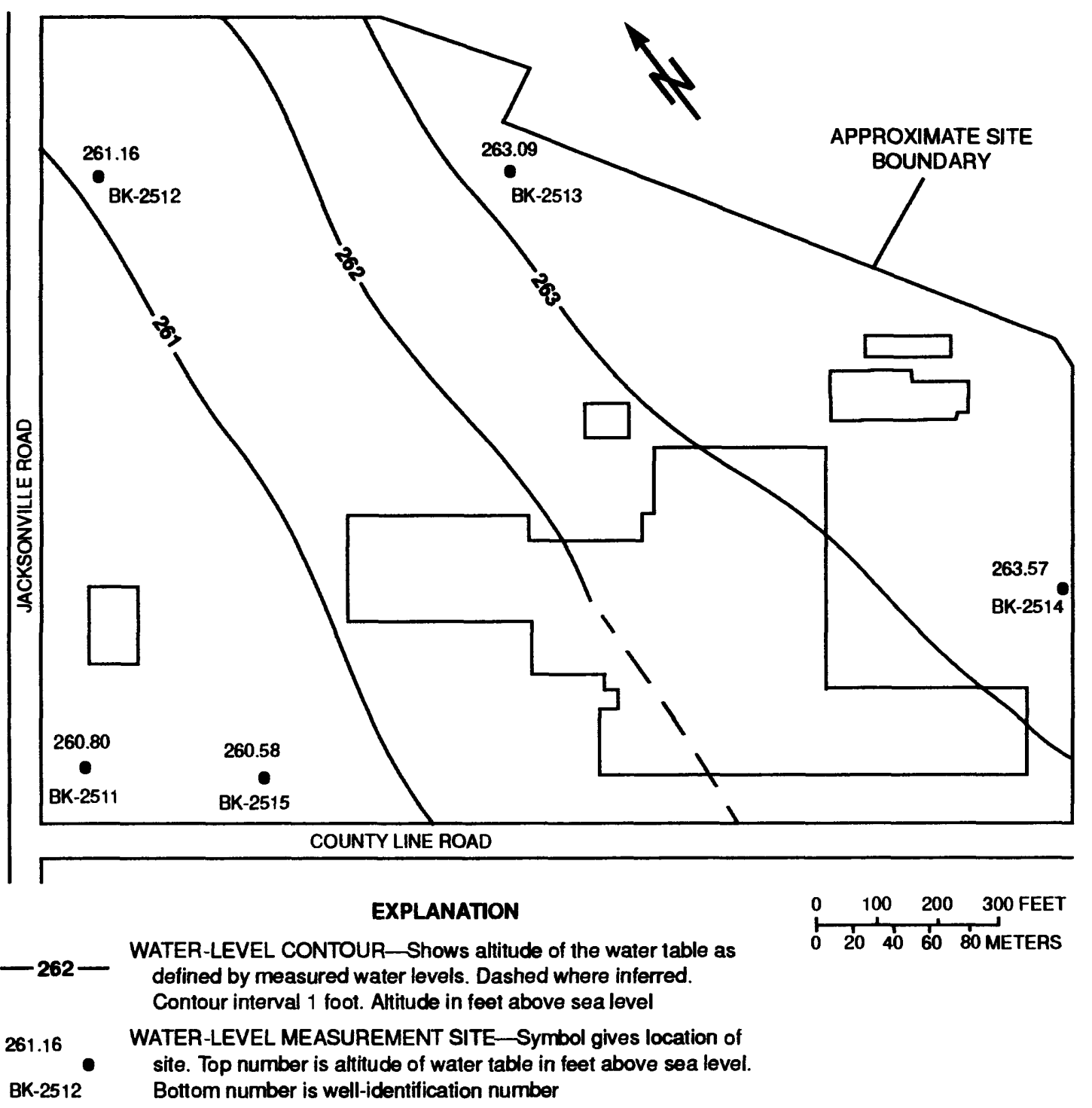

Figure 17. Water-level contour map for wells screened in the deep zone, Fischer and Porter Site, Warminster, Pa., May 3, 1994. 


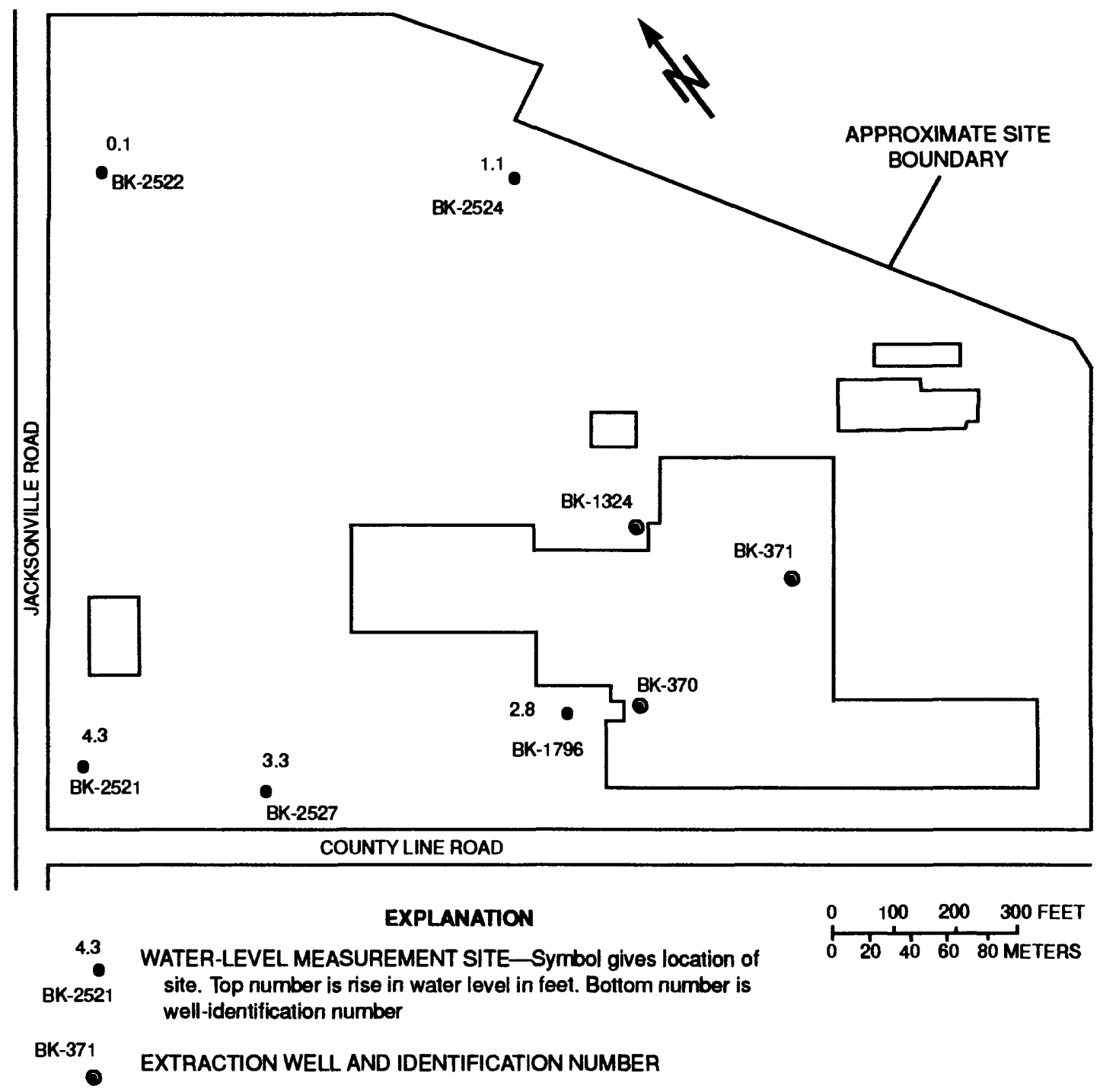

Figure 18. Rise in water level in wells screened in the intermediate zone caused by the shutdown of the treatment system wells, Fischer and Porter Site, Warminster, Pa. 


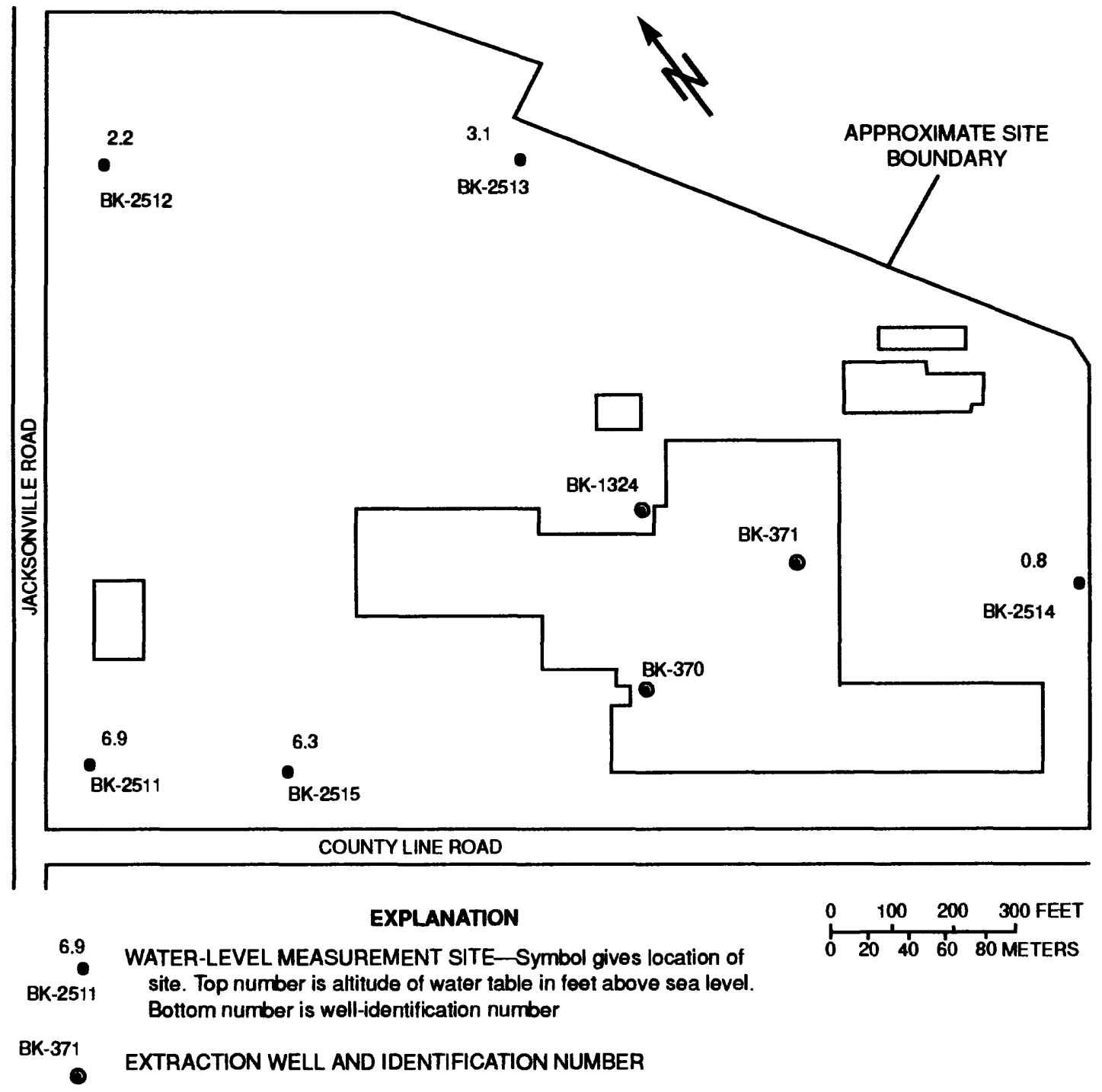

Figure 19. Rise in water level in wells screened in the deep zone caused by the shutdown of the treatment system wells, Fischer and Porter Site, Warminster, $\mathrm{Pa}$. 


\section{VERTICAL DISTRIBUTION OF VOLATILE ORGANIC COMPOUNDS}

Results of laboratory analysis for VOC's in water samples collected at the end of aquifer-isolation tests from 30 intervals isolated in 6 boreholes are given in appendix 5 . A summary of compounds detected in water samples from each onsite borehole are given in tables $1 \% \cdot 21$. On the basis of laboratory and field blanks, chloroform and benzene are considered laboratory contaminants, and toluene is considered a field contaminant.

Trichloroethylene (TCE), tetrachloroethylene (PCE), 1,1,1-trichloroethane (TCA), cis1,2-dichloroethylene (cis-1,2-DCE), 1,1-dichloroethylene (1,1-DCE), 1,1-dichloroethane, 1,2-dichloroethane, and vinyl chloride were detected in water samples collected during the aquifer-isolation tests. TCE, PCE, and TCA were detected in 77,69, and 54 percent, respectively, of onsite water samples. Concentrations of TCE ranged up to $96 \mu \mathrm{g} / \mathrm{L}, \mathrm{PCE}$ up to $14 \mu \mathrm{g} / \mathrm{L}$, and TCA up to $9.1 \mu \mathrm{g} / \mathrm{L}$. None of the isolated intervals had highly elevated concentrations of VOC's. Concentrations of all VOC's detected in water samples from offsite borehole MG-1242 were less than $2 \mu \mathrm{g} / \mathrm{L}$ (appendix 5, table 6).

Anaerobic degradation products of TCE and PCE (fig. 20) were detected in some water samples. Degradation products cis-1,2-DCE and 1,1-DCE were detected in most water samples where the concentration of TCE was greater than $70 \mu \mathrm{g} / \mathrm{L}$. Degradation product vinyl chloride was detected in two water samples where the concentration of TCE was greater than $80 \mu \mathrm{g} / \mathrm{L}$. The water sample (isolated interval 132-160 ft bls in borehole BK-2512) with the greatest concentration of TCE $(96 \mu \mathrm{g} / \mathrm{L})$ also had the greatest concentration of vinyl chloride $(5.8 \mu \mathrm{g} / \mathrm{L})$.

No general trend of increasing or decreasing concentrations of VOC's with depth were observed. VOC's generally were evenly distributed throughout all intervals tested and were present in water samples from the isolated interval closest to land surface (37-72 $\mathrm{ft}$ bls in borehole BK-2314) to the deepest isolated interval (305-352 ft bls in borehole BK-25111).

The fairly constant concentrations of VOC's with depth are the result of two factors, the downward head gradient and the presence of open boreholes on the site in the past. The downward head gradient at the site, caused in part by the pumping of nearby publicsupply wells BK-366 and BK-367, caused the vertical migration of VOC's into the aquifer through wells BK-370 and BK-371 between the time they were taken out of service as supply wells and the time that they were put into service as extraction wells and through well BK-1324 between the time that it was drilled and the time it was put into service as an extraction well. These three wells are of open-hole construction and are located in the main area of contamination. SMC-Martin, Inc. (1980, tables 1, 3, and 8) reported concentrations of TCE to $66,400 \mu \mathrm{g} / \mathrm{L}$, PCE to $26,000 \mu \mathrm{g} / \mathrm{L}$, and TCA to $610 \mu \mathrm{g} / \mathrm{L}$ in water samples from well BK-370; TCE to 7,500 $\mu \mathrm{g} / \mathrm{L}$, PCE to $190 \mu \mathrm{g} / \mathrm{L}$, and TCA to $97 \mu \mathrm{g} / \mathrm{L}$ in water samples from well BK-371; and TCE to $15,000 \mu \mathrm{g} / \mathrm{L}, \mathrm{PCE}$ to $920 \mu \mathrm{g} / \mathrm{L}$, and TCA to $4,600 \mu \mathrm{g} / \mathrm{L}$ in water samples from well BK-1324. High concentrations of these VOC's migrated downward in the open boreholes in response to the downward head gradient and then moved outward into the aquifer at different depths in response to pumping and natural hydraulic gradients.

Concentrations of TCE detected in water samples from borehole BK-2511 (table 17) ranged from 73 to $88 \mu \mathrm{g} / \mathrm{L}$, and TCE was about evenly distributed through all isolated intervals. Concentrations of PCE ranged from 8.6 to $14 \mu \mathrm{g} / \mathrm{L}$. The highest concentrations of TCE, PCE, cis-1,2-DCE, and 1,1-DCE were in the upper two isolated intervals above 187 $\mathrm{ft}$ and $211-239 \mathrm{ft}$ bls.

Concentrations of TCE in water samples from borehole BK-2512 (table 18) ranged from 56 to $96 \mu \mathrm{g} / \mathrm{L}$, and concentrations of PCE ranged from below the minimum reporting level to $37 \mu \mathrm{g} / \mathrm{L}$. The highest concentrations of VOC's were detected in the 
interval 132-160 ft bls, which is a water-receiving zone identified by borehole geophysical logging. The concentrations of VOC's in the interval 132-160 ft bls are greater than the concentrations of VOC's in the interval above $115 \mathrm{ft}$ bls, which includes the waterproducing zone that contributes borehole flow to the interval $132-160 \mathrm{ft}$ bls.

Concentrations of TCE in water samples from borehole BK-2513 (table 20) ranged from 20 to $43 \mu \mathrm{g} / \mathrm{L}$, and concentrations of PCE ranged from 2.3 to $11 \mu \mathrm{g} / \mathrm{L}$. A water sample collected from nearby public-supply well BK-366 by the Fischer and Porter Company on May 26, 1993, had a TCE concentration of $41 \mu \mathrm{g} / \mathrm{L}$ and a PCE concentration of $3.1 \mu \mathrm{g} / \mathrm{L}$. These concentrations are similar to concentrations in water samples from borehole BK-2513.

TCE in water samples from borehole BK-2514 (table 20) was detected $(9.7 \mu \mathrm{g} / \mathrm{L}$ ) above the minimum reporting level only in the interval above $72 \mathrm{ft}$ bls. PCE was not detected in any isolated interval. A water sample collected from nearby public-supply well BK-367 by the Fischer and Porier Company on May 26, 1993, had a TCE concentration of less than 1 $\mu \mathrm{g} / \mathrm{L}$ and a PCE concentration of $10 \mu \mathrm{g} / \mathrm{L}$.

Concentrations of TCE in water samples from borehole BK-2515 (table 21) ranged from 71 to $84 \mu \mathrm{g} / \mathrm{L}$, and concentrations of PCE ranged from 6.3 to $7.3 \mu \mathrm{g} / \mathrm{L}$. Vinyl chloride was detected at a concentration of $1.7 \mu \mathrm{g} / \mathrm{L}$ in the interval above $172 \mathrm{ft}$ bls.

Table 17. Volatile organic compounds detected in water samples from borehole BK-2511, Fischer and Porter Site, Warminster, Pa.

[Concentrations given in micrograms per liter; <, less than]

\begin{tabular}{lcccc}
\hline \multirow{2}{*}{ Compound } & \multicolumn{4}{c}{ Sampled depth interval (feet below land surface) } \\
\cline { 2 - 5 } & Above 187 & $211-239$ & $241-269$ & Below 305 \\
\hline 1,1-Dichloroethane & 1.5 & 1.7 & 1.4 & 1.1 \\
1,1-Dichloroethylene & 4.3 & 4.5 & 3.7 & 2.6 \\
cis-1,2-Dichloroethene & 17 & 19 & 15 & 14 \\
1,2-Dichloropropane & 2.3 & $<.8$ & $<.8$ & $<.8$ \\
Tetrachloroethylene & 14 & 14 & 11 & 8.6 \\
1,1,1-Trichloroethane & 2.8 & 1.9 & 1.2 & $<.8$ \\
Trichloroethylene & 88 & 87 & 78 & 73 \\
\hline
\end{tabular}

Table 18. Volatile organic compounds detected in water samples from borehole BK-2512, Fischer and Porter Site, Warminster, Pa.

[Concentrations given in micrograms per liter; <, less than]

\begin{tabular}{lccccccc}
\hline \multirow{2}{*}{ Compound } & \multicolumn{5}{c}{ Sampled depth interval (feet below land surface) } \\
\cline { 2 - 7 } & Above 115 & $132-160$ & $164-192$ & $204-235$ & $237-265$ & Below 265 \\
\hline 1,1-Dichloroethane & $<0.8$ & $<0.8$ & $<0.8$ & $<0.8$ & $<0.8$ & 1.6 \\
1,2-Dichloroethane & $<.8$ & 8.3 & 2.1 & 1.9 & 1.8 & $<.8$ \\
1,1-Dichloroethylene & $<.8$ & 5.5 & 1.0 & $<.8$ & $<.8$ & 2.0 \\
cis-1,2-Dichloroethene & 8.2 & 55 & 30 & 25 & 29 & 27 \\
Tetrachloroethylene & 5.9 & 37 & 12 & 11 & $<.8$ & 13 \\
1,1,1-Trichloroethane & $<.8$ & 1.8 & $<.8$ & .9 & $<.8$ & 1.3 \\
Trichlonoethylene & 56 & 96 & 75 & 75 & 76 & 82 \\
Vinyl chloride & $<.8$ & 5.8 & $<.8$ & $<.8$ & $<.8$ & $<.8$ \\
\hline
\end{tabular}


Table 19. Volatile organic compounds detected in water samples from borehole BK-2513, Fischer and Porter Site, Warminster, Pa.

[Concentrations given in micrograms per liter; <, less than]

\begin{tabular}{lccccccc}
\hline \multirow{2}{*}{ Compound } & \multicolumn{5}{c}{ Sampled depth interval (feet below land surface) } \\
\cline { 2 - 7 } & Above 143 & $143-171$ & $176-204$ & $202-232$ & $232-260$ & Below 260 \\
\hline 1,2-Dichloroethane & 29 & 35 & 23 & 27 & 6.5 & 6.7 \\
Ethylbenzene & $<.8$ & $<.8$ & $<.8$ & $>.8$ & $<.8$ & 2.5 \\
Tetrachloroethylene & 10 & 11 & 4.5 & 2.3 & 3.8 & 4.4 \\
1,1,1-Trichloroethane & 1.2 & 1.4 & $<.8$ & 1.7 & 2.5 & .8 \\
Trichloroethylene & 39 & 43 & 34 & 37 & 20 & 20 \\
\hline
\end{tabular}

Table 20. Volatile organic compounds detected in water samples from borehole BK-2514, Fischer and Porter Site, Warminster, Pa.

[Concentrations given in micrograms per liter; <, less than]

\begin{tabular}{lcccccccc}
\hline \multirow{2}{*}{ Compound } & \multicolumn{7}{c}{ Sampled depth interval (feet below land surface) } \\
\cline { 2 - 8 } & Above 72 & $72-100$ & $100-128$ & $130-158$ & $177-205$ & $209-237$ & Below 237 \\
\hline 1,1-Dichloroethane & $<0.8$ & $<0.8$ & $<0.8$ & $<0.8$ & $<0.8$ & 1.1 & $<0.8$ \\
1,2-Dichloroethane & 4.5 & $<.8$ & $<.8$ & $<.8$ & $<.8$ & $<.8$ & $<.8$ \\
1,1,1-Trichloroethane & $<.8$ & .8 & $<.8$ & 9.1 & $<.8$ & $<.8$ & 1.1 \\
Trichloroethylene & 9.7 & $<.8$ & $<.8$ & $<.8$ & $<.8$ & $<.8$ & $<.8$ \\
\hline
\end{tabular}

Table 21. Volatile organic compounds detected in water samples from borehole BK-2515, Fischer and Porter Site, Warminster, Pa.

[Concentrations given in micrograms per liter]

\begin{tabular}{lccc}
\hline \multirow{2}{*}{ Compound } & \multicolumn{3}{c}{ Sampled depth interval (feet below land surface) } \\
\cline { 2 - 4 } & Above 172 & $172-200$ & Below 277 \\
\hline 1,1-Dichloroethane & 3.1 & 1.7 & 2.0 \\
1,1-Dichloroethylene & 6.6 & 5.6 & 2.0 \\
cis-1,2-Dichloroethene & 17 & 14 & 19 \\
Tetrachloroethylene & 6.3 & 7.3 & 7.3 \\
Trichloroethylene & 84 & 71 & 76 \\
Vinyl chloride & 1.3 & $<.8$ & $<.8$ \\
\hline
\end{tabular}

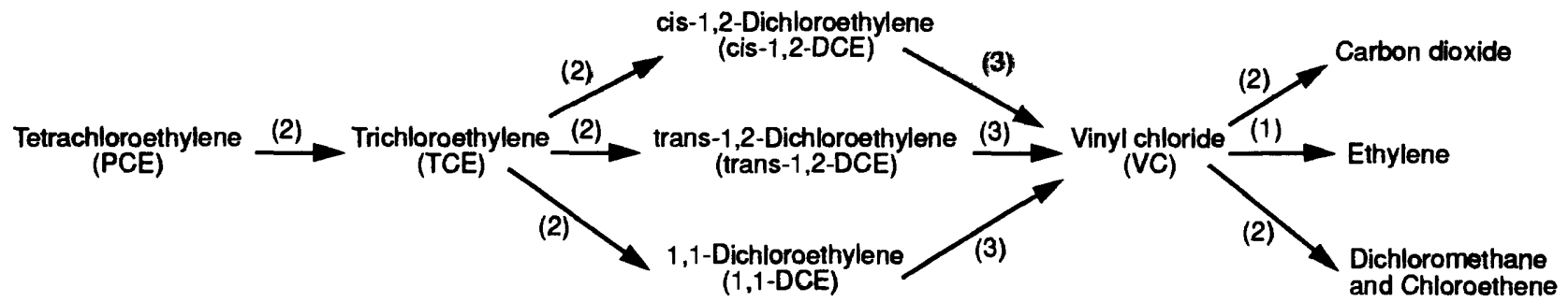

Figure 20. Typical reaction pathways for the anaerobic degradation of tetrachloroethylene and trichloroethylene by reductive dehalogenation. Reactions from: (1) Freedman and Gossett (1989); (2) Parsons and others (1984); and (3) Vogel and McCarty (1985). 


\section{SUMMARY AND CONCLUSIONS}

The Fischer and Porter Company Superfund Site is underlain by sedimentary rocks of the Upper Triassic Stockton Formation, which consist of interbedded siltstone, very-fine grained to coarse-grained sandstone, and conglomerate in crudely defined, upward fining cycles. The rocks of the Stockton Formation form a complex, heterogeneous, leaky, multiaquifer system comprised of a series of gently dipping lithologic units with different hydraulic properties. In general, the sandstone units are the principle water-bearing units, but some of the finer-grained units may contain water-bearing zones. Ground water is unconfined in the shallower part of the aquifer and confined or semiconfined in the deeper part of the aquifer. Differences in the ratio of vertical to horizontal hydraulic conductivity, as well as differences in vertical hydraulic conductivity within and among lithologic units, create confining conditions.

Water levels measured in monitor well clusters and borehole-flow measurements made in open boreholes show a downward hydraulic head gradient at the site. Water moves downward through the aquifer system in response to this downward head gradient, which is caused in part by the pumping of nearby, deep public-supply wells and the Fischer and Porter treatment system extraction wells. Differences in head in open boreholes cause water in the well bore to flow under nonpumping conditions in the direction of decreasing head. Downward borehole flow was measured at rates up to 0.5 , 1.7, and $9 \mathrm{gal} / \mathrm{min}$ in boreholes BK-372, BK-2511, and BK-2514, respectively.

Aquifer-isolation tests were run in the five exploratory boreholes and offsite borehole MG-1242. On the basis of specific-capacity data for 27 isolated intervals, specific capacity is not related to depth. Three of the isolated intervals with specific capacities greater than 1 (gal/min)/ft were identified by borehole geophysical logging as water-receiving zones, and one was identified as a water-producing zone.

Water levels in monitor wells at the Fischer and Porter Site are greatly affected by the pumping of public-supply wells BK-366 and BK-367 as well as the pumping of the Fischer and Porter treatment system extraction wells. Pumping of the public-supply wells causes daily water-level fluctuations in wells at the site as great as $5.3 \mathrm{ft}$. The shutdown of the Fischer and Porter treatment system extraction wells had only a small effect on water levels in the shallow zone. Estimated rises in water level were less than $1 \mathrm{ft}$. The shutdown of the Fischer and Porter treatment system extraction wells caused a rise in water level in all wells screened in the intermediate and deep zones. The rise in water level was as great as $4.3 \mathrm{ft}$ in the intermediate zone and as great as $5.9 \mathrm{ft}$ in the deep zone.

The response of water levels to stress generally is more related to the depth of the stratigraphic unit that a well is screened in than to the particular stratigraphic unit the well is screened in. Water levels in wells screened in the same depth interval respond to stress in a similar manner and are contourable. Water levels measured in all wells screened in a particular stratigraphic unit are not contourable.

On the basis of water levels measured on December 13, 1993, and May 3, 1994, the direction of ground-water flow in the shallow and intermediate zones is toward the north; discharge is to the unnamed tributary to Pennypack Creek north of the site. The direction of ground-water flow in the deep zone was toward the west-southwest on December 13 and toward the west on May 3; discharge probably is to the unnamed tributary to Pennypack Creek west of the site.

TCE, PCE, TCA, cis-1,2-DCE, 1,1-DCE, 1,1-dichloroethane, 1,2-dichloroethane, and vinyl chloride were detected in water samples collected during the aquifer-isolation tests. TCE, PCE, and TCA were detected in 77, 69, and 54 percent, respectively, of onsite water samples. Concentrations of TCE ranged up to $96 \mu \mathrm{g} / \mathrm{L}, \mathrm{PCE}$ up to $14 \mu \mathrm{g} / \mathrm{L}$, and TCA up to $9.1 \mu \mathrm{g} / \mathrm{L}$. Anaerobic degradation products cis-1,2-DCE and 1,1-DCE were detected in most water samples where the concentration of TCE was greater than $70 \mu \mathrm{g} / \mathrm{L}$, and vinyl 
chloride was detected in two water samples where the concentration of TCE was greater than $80 \mu \mathrm{g} / \mathrm{L}$. No general trend of increasing or decreasing concentrations of VOC's with depth were observed. None of the isolated intervals had highly elevated concentrations of VOC's.

The fairly constant concentrations of VOC's with depth are the result of the downward head gradient and the presence of open boreholes on the site. The downward head gradient at the site, caused in part by the pumping of nearby public-supply wells caused the vertical migration of VOC's into the aquifer through wells BK-370 and BK-371 between the time they were taken out of service as supply wells and the time that they were put into service as extraction wells and through well BK-1324 between the time that it was drilled and the time it was put into service as an extraction well. These three wells are of open-hole construction and are located in the main area of contamination. VOC's migrated downward in the open boreholes in response to the downward head gradient and then moved outward into the aquifer at different depths in response to the pumping of nearby wells and natural hydraulic gradients. 


\section{REFERENCES CITED}

BCM, Incorporated, 1986, Hydrogeological report for Fischer and Porter Company, Warminster, Pennsylvania: Plymouth Meeting, Pa., variously paginated.

Freedman, D.L., and Gossett, J.M., 1989, Biological reductive dechlorination of tetrachloroethylene and trichloroethylene to ethylene under methanogenic conditions: Applied and Environmental Microbiology, v. 55, p. 2,144-2,151.

Glaeser, J.D., 1966, Provenance, dispersal, and depositional environments of Triassic sediments in the Newark-Gettysburg Basin: Pennsylvania Geological Survey, 4th ser., Bulletin G43, 170 p.

Kammer, J.A., and Gibbs, Jacob, 1989, An analytical technique for screening purgeable volatile organic compounds in water: U.S. Geological Survey Open-File Report 89-53, 13 p.

Keys, W.S., 1990, Borehole geophysics applied to ground-water investigations: U.S. Geological Survey Techniques of Water-Resources Investigations, book 2, chap. E2, 149 p.

Owenby, J.R., and Ezell, D.S., 1992, Monthly station normals of temperature, precipitation, and heating and cooling degree days, 1961-1990, Pennsylvania: National Oceanic and Atmospheric Administration Climatography of the United States No. 81, 25 p.

Parsons, Frances, Wood, P.R., and DeMarco, Jack, 1984, Transformations of tetrachloroethane and trichloroethylene in microcosms and groundwater: Journal of the American Water Works Association, v. 76, p. 56-59.

Patten, E.P., Jr., and Bennett, G.D., 1962, Methods of flow measurement in well bores: U.S. Geological Survey Water-Supply Paper 1544-C, 28 p.

Rima, D.R., Meisler, Harold, and Longwill, Stanley, 1962, Geology and hydrology of the Stockton Formation in southeastern Pennsylvania: Pennsylvania Geologic Survey, 4th ser., Water Resources Report 14, 111 p.

Sloto, R.A., 1995, Sampling borehole flow to quantify aquifer cross-contamination by volatile organic compounds: Proceedings of the U.S. Geological Survey Toxic Substances Hydrology Technical Meeting, Colorado Springs, Colorado, September 20-24, 1993, U.S. Geological Survey Water-Resources Investigations Report 94-4015.

Sloto, R.A., and Davis, D.K., 1983, Effect of urbanization on the water resources of Warminster Township, Bucks County, Pennsylvania: U.S. Geological Survey Water-Resources Investigations Report 82-4020, 72 p.

Sloto, R.A., Macchiaroli, Paola, and Towle, W.T., 1994, Use of borehole geophysical methods to investigate aquifer cross-contamination by volatile organic compounds in the Stockton Formation, Hatboro, Pennsylvania: Proceedings of the U.S. Geological Survey workshop on the application of borehole geophysics to ground-water investigations, U.S. Geological Survey Water-Resources Investigations Report 94-4103, p. 54-57. 


\section{REFERENCES CITED-Continued}

Sloto, R.A., Macchiaroli, Paola, and Towle, M.T., 1992, Identification of a multiaquifer ground-water cross-contamination problem in the Stockton Formation by use of borehole geophysical methods, Hatboro, Pennsylvania: Proceedings, Symposium on the Application of Geophysics to Engineering and Environmental Problems, Oakbrook, Illinois, April 26-29, 1992, Society of Engineering and Mineral Exploration Geophysicists, p. 21-35.

SMC-Martin, Incorporated, 1980, Hydrogeological study of Fischer and Porter company and vicinity, Warminster Township, Bucks County, Pennsylvania: King of Prussia, $\mathrm{Pa}$., variously paginated.

Turner-Peterson, C.E., and Smoot, J.P., 1985, New thoughts on facies relationships in the Triassic Stockton and Lockatong Formations, Pennsylvania and New Jersey: U.S. Geological Survey Circular 946, p. 10-17.

U.S. Environmental Protection Agency, 1992, Superfund progress at National Priority List Sites, Pennsylvania 1992 Update: U.S. Environmental Protection Agency publication 9200.5-738B, $242 \mathrm{p}$.

Vogel, T.M., and McCarty, P.L., 1985, Biotransformation of tetrachloroethylene to trichloroethylene, dichloroethylene, vinyl chloride, and carbon dioxide under methanogenic conditions: Applied and Environmental Microbiology, v. 49, p. $1,080-1,083$. 

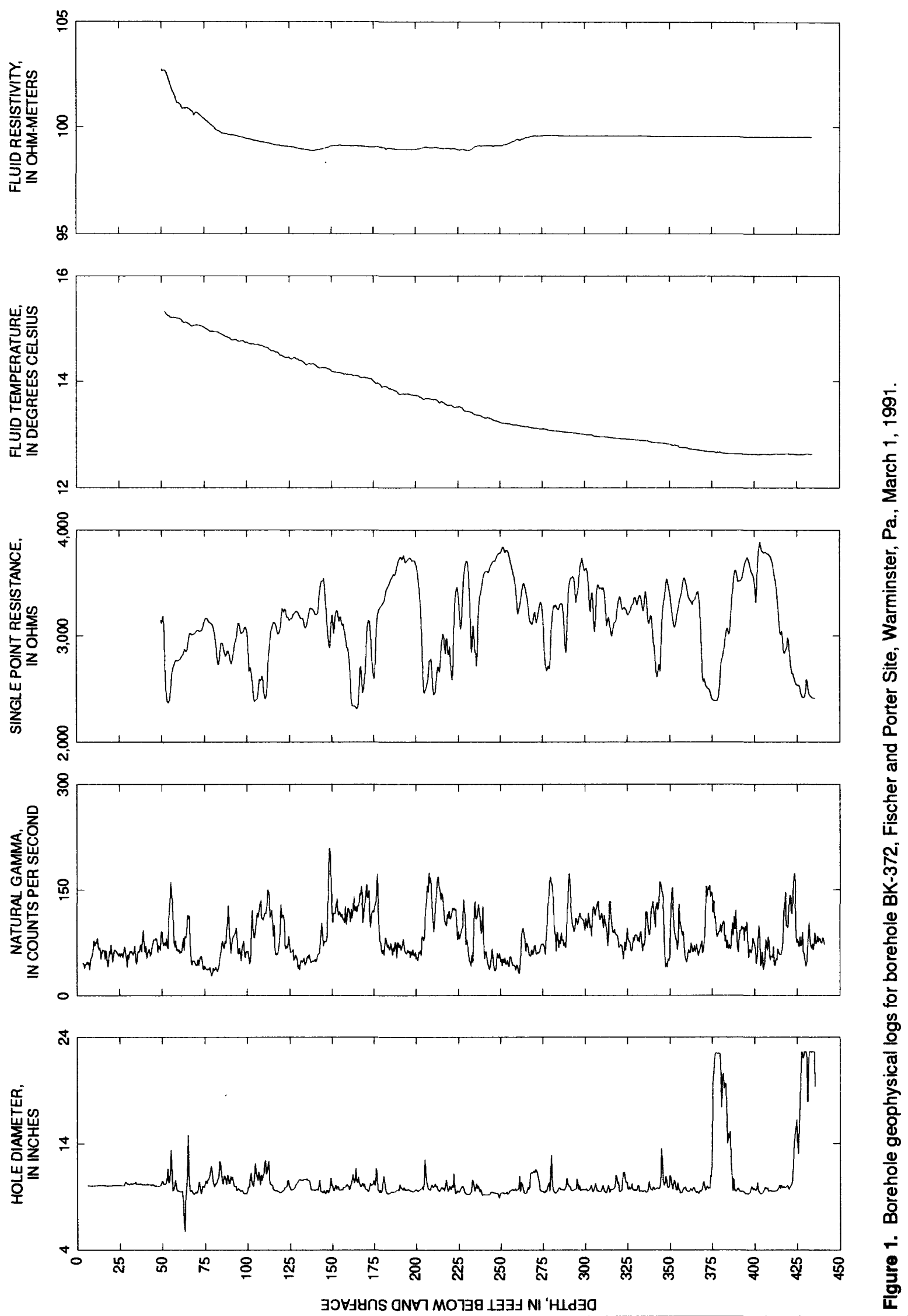


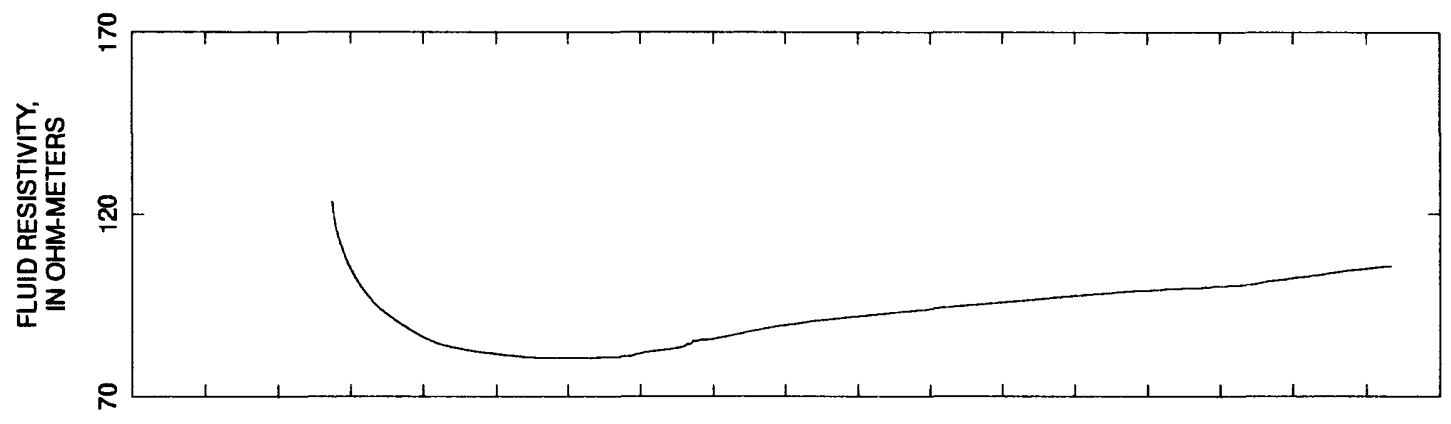

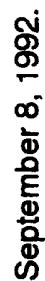
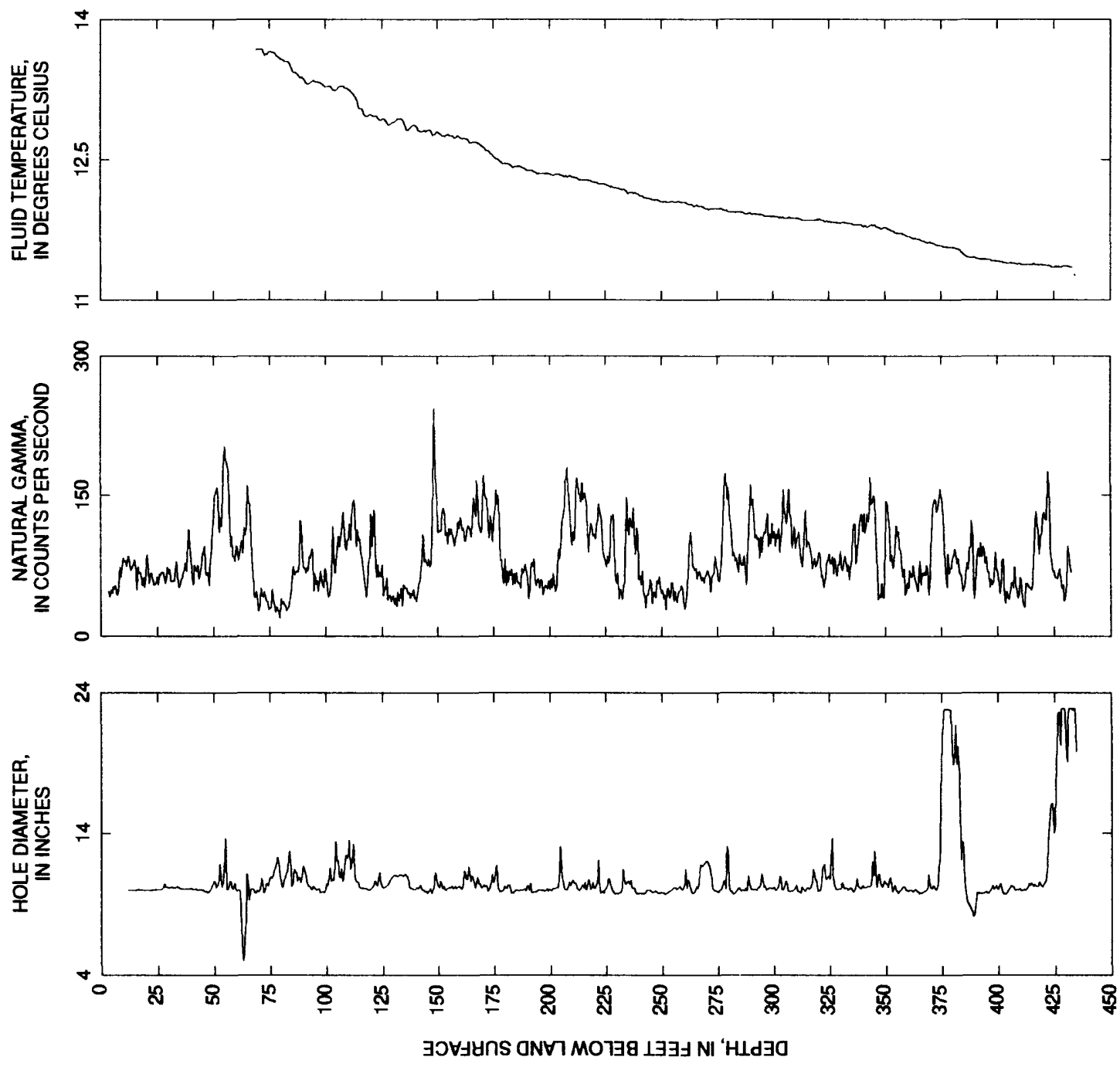

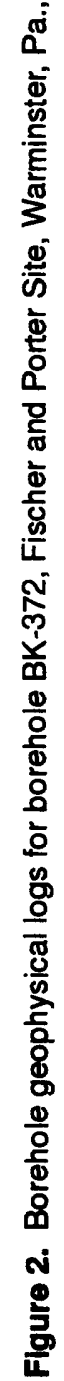



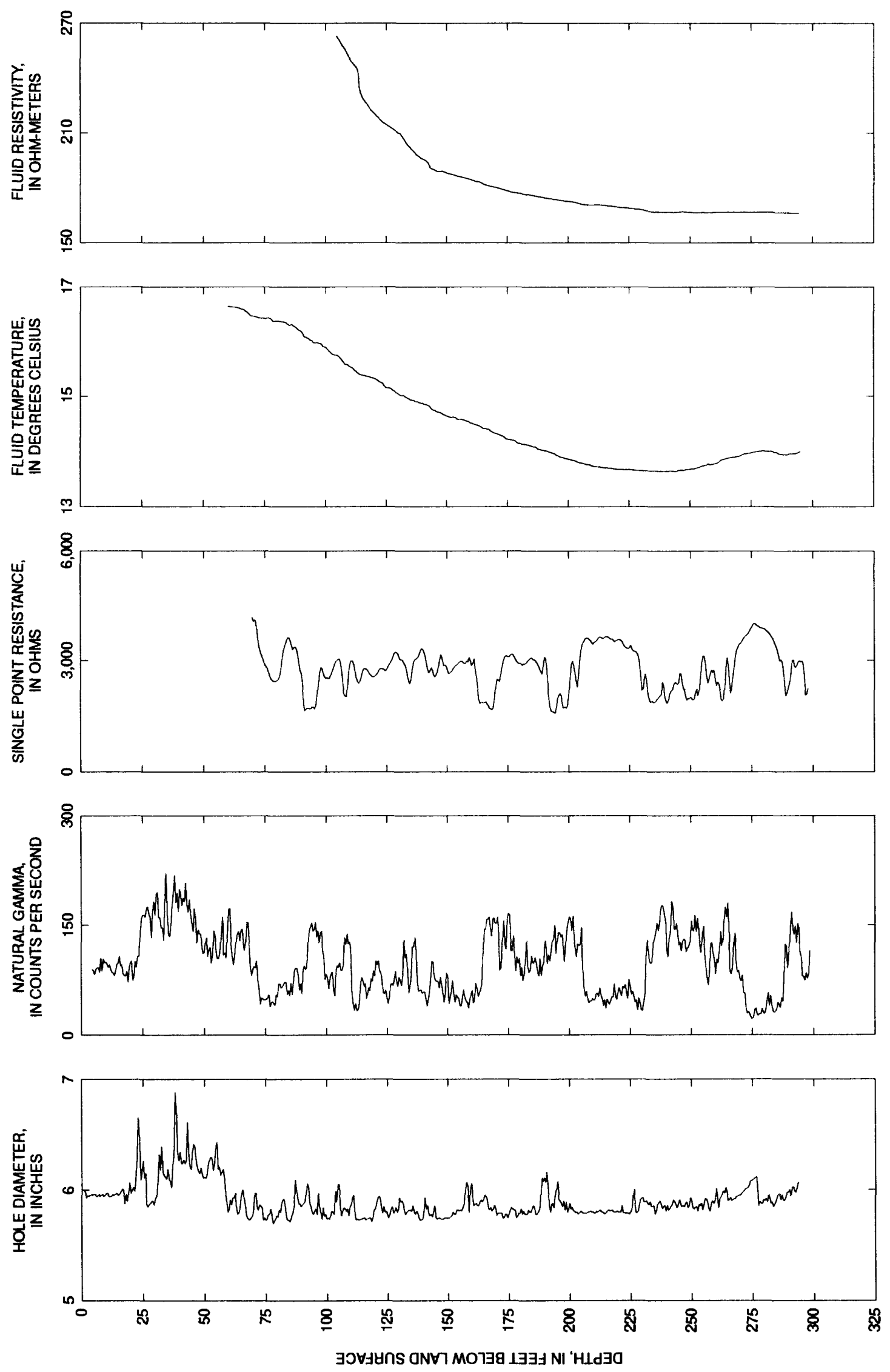

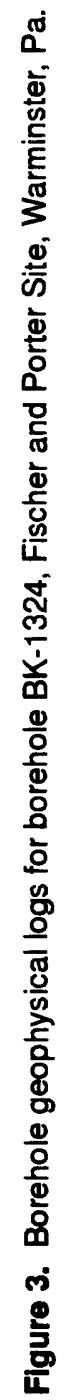



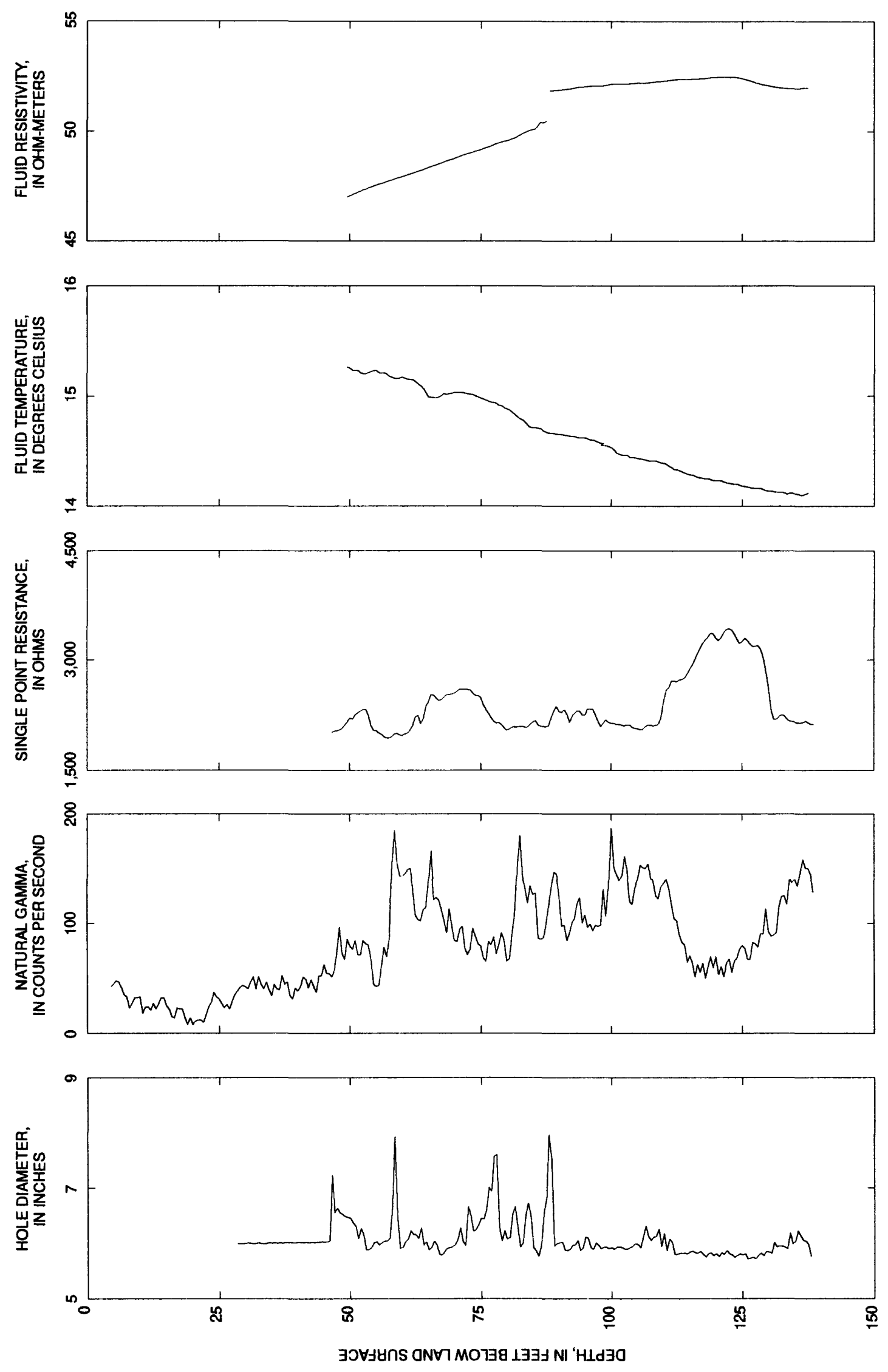

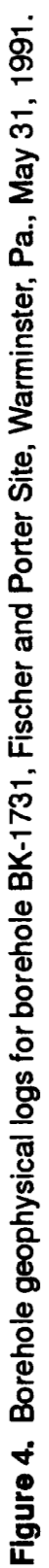



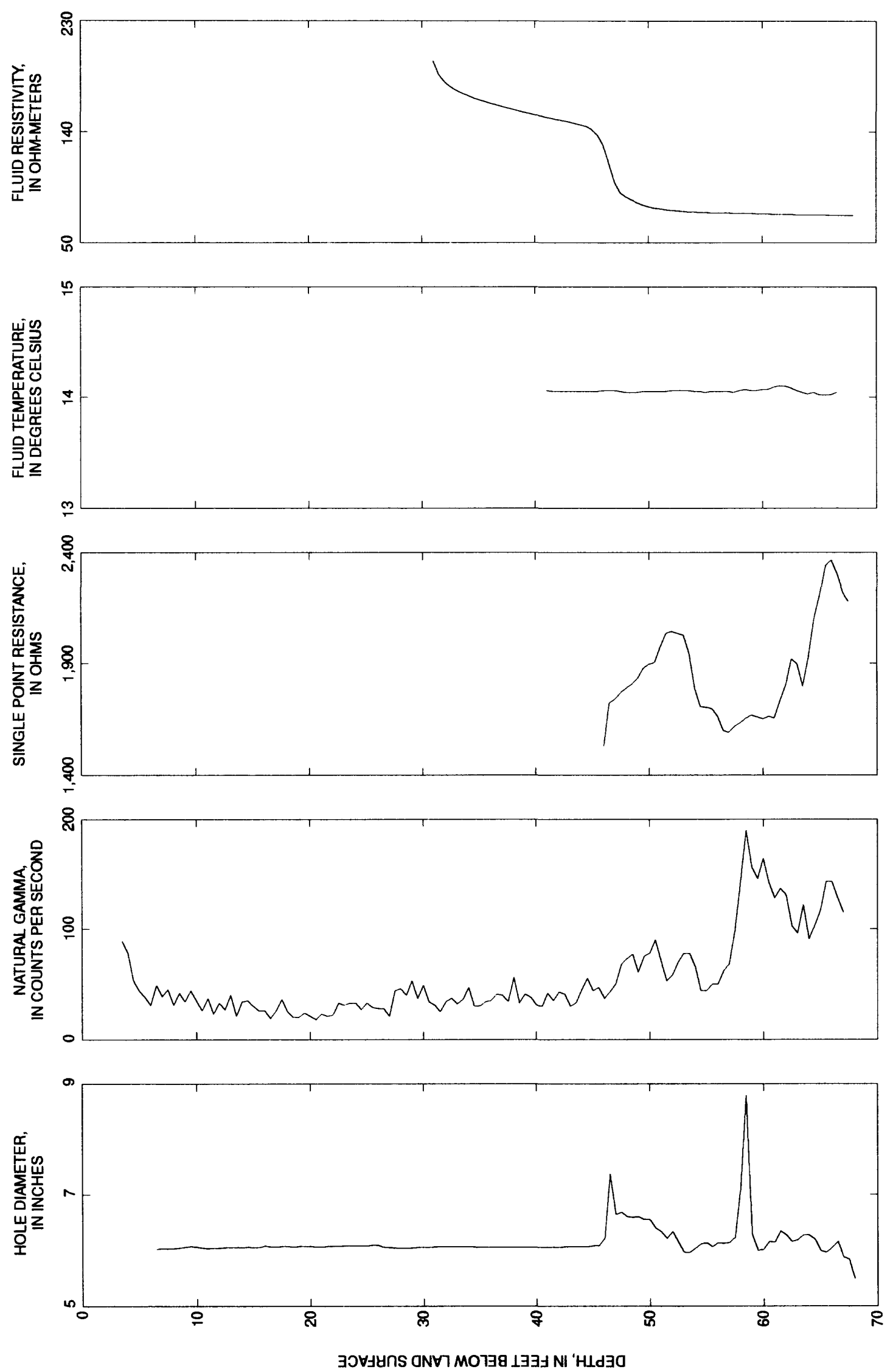

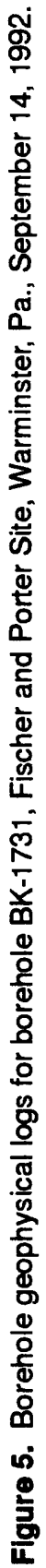




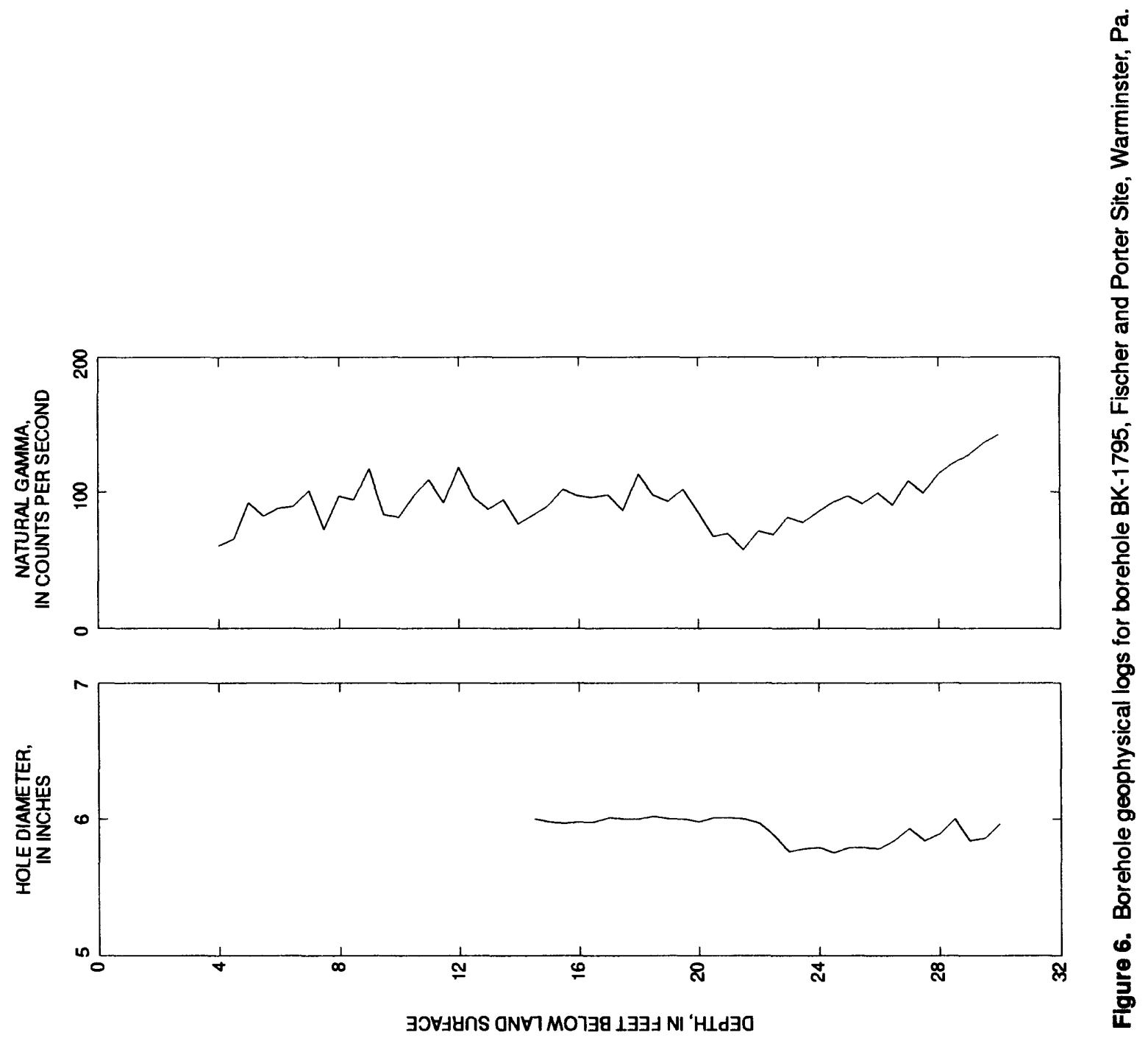



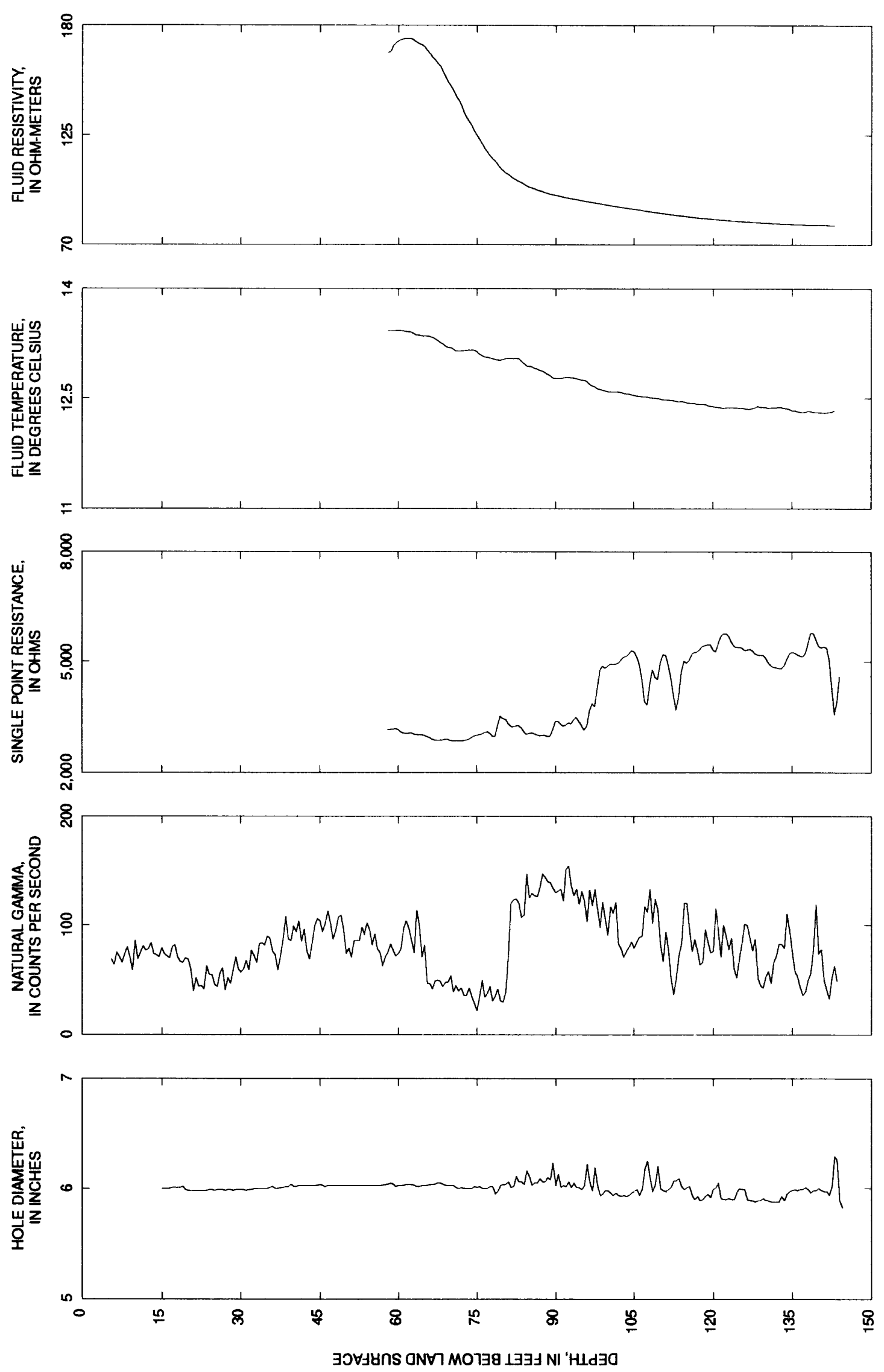

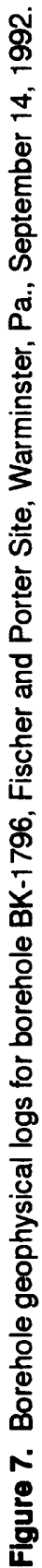




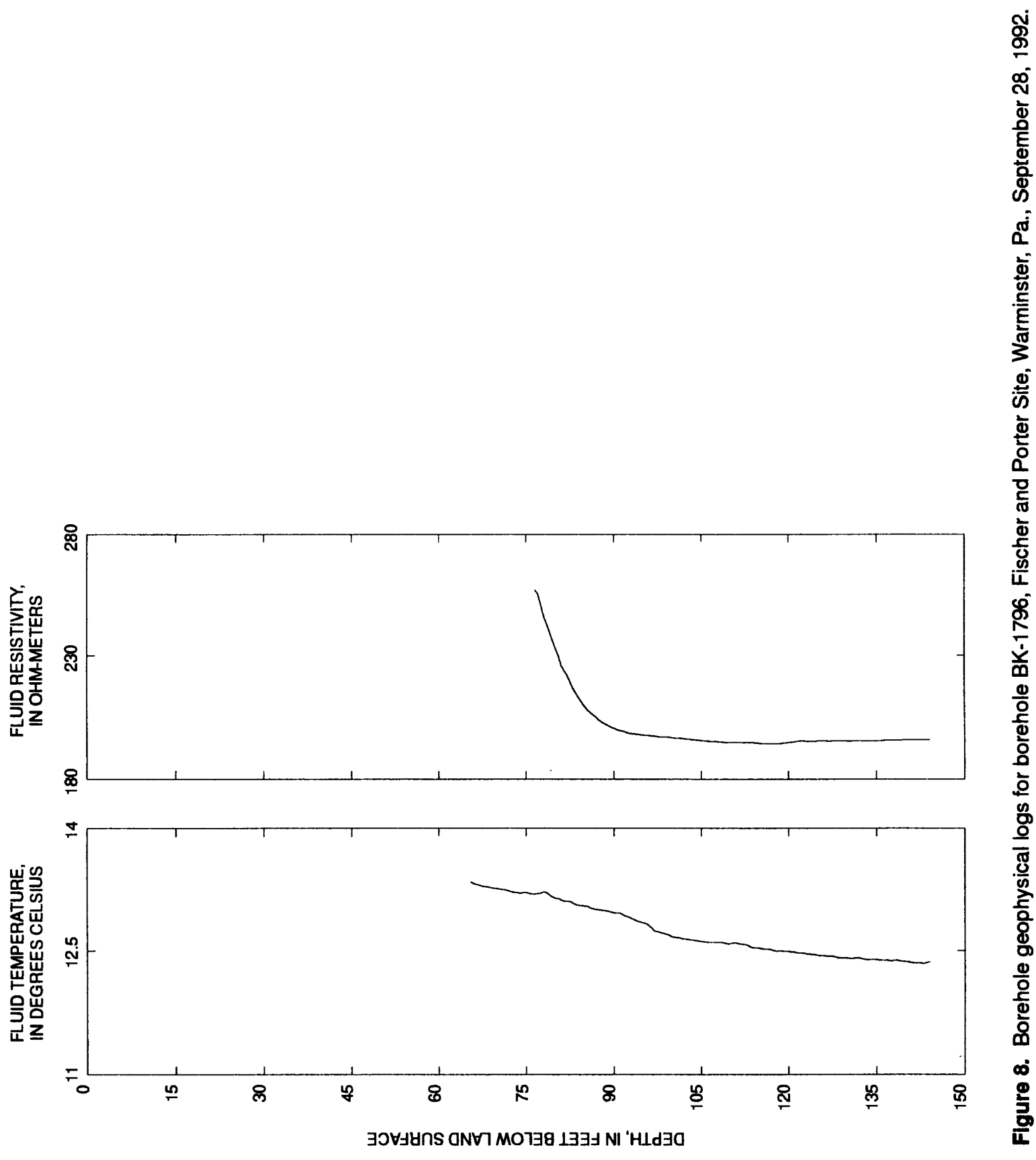




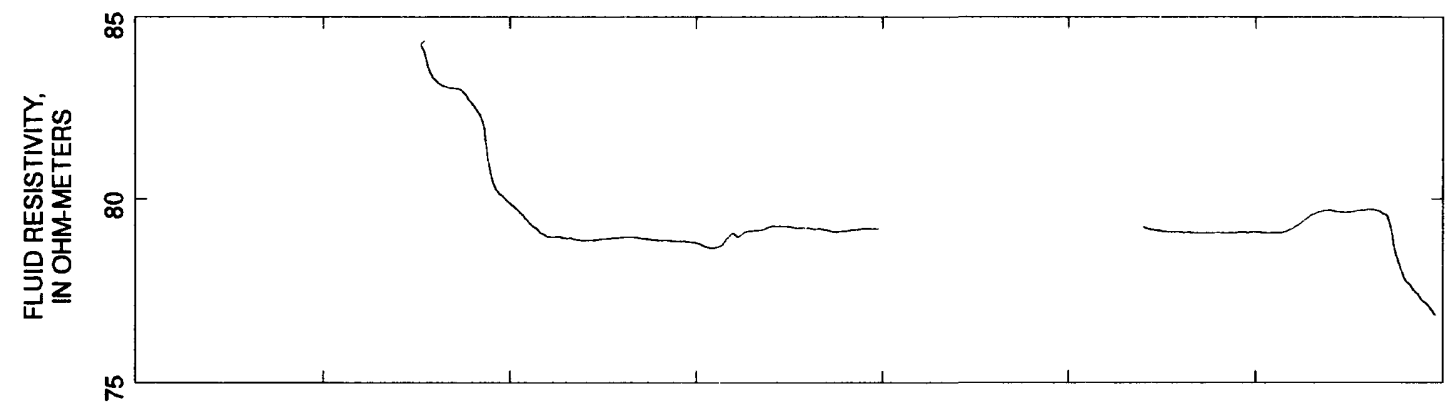

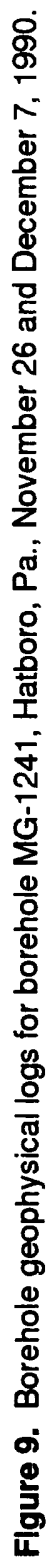



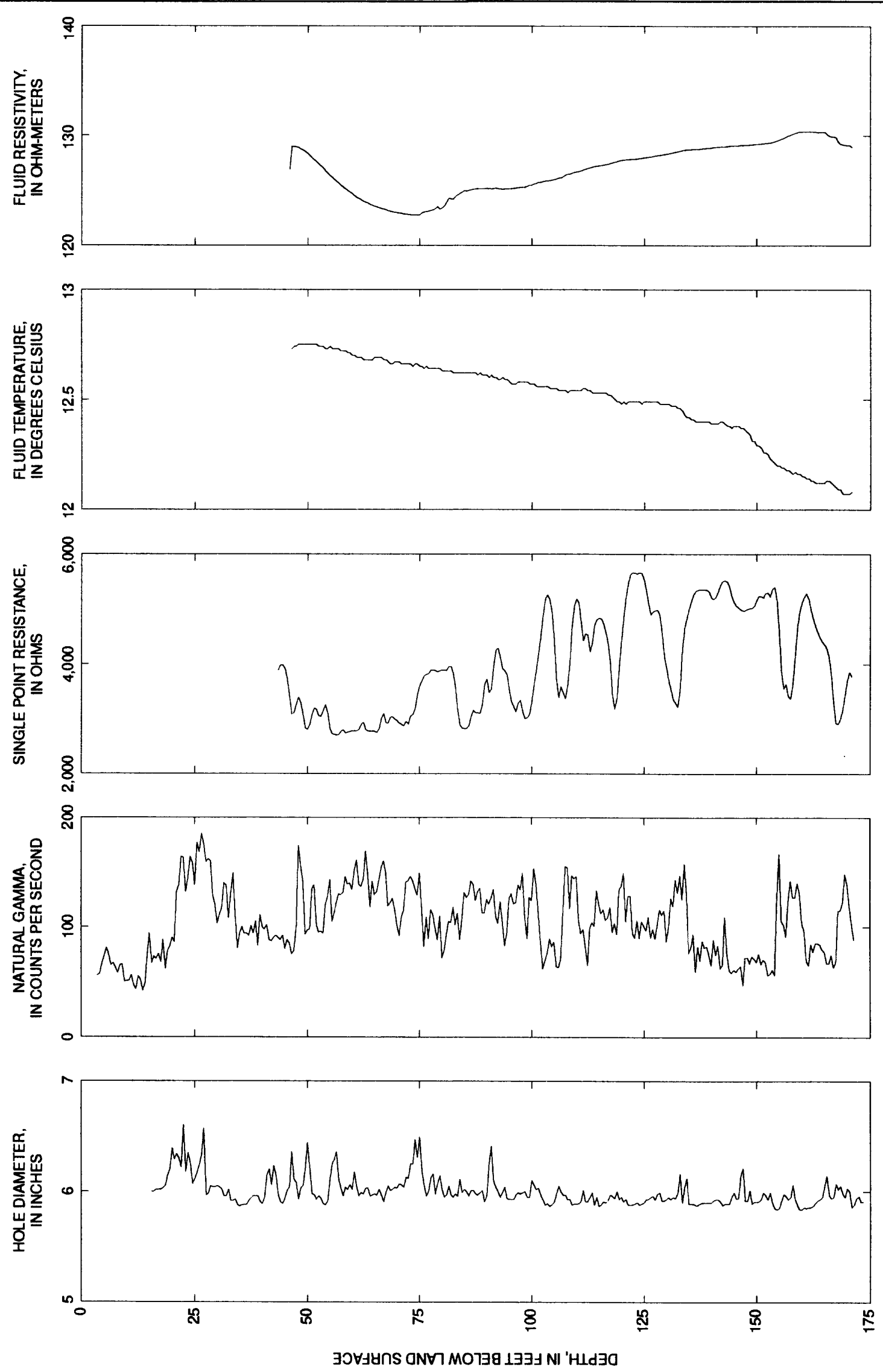

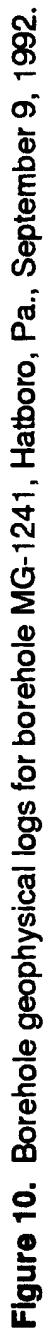



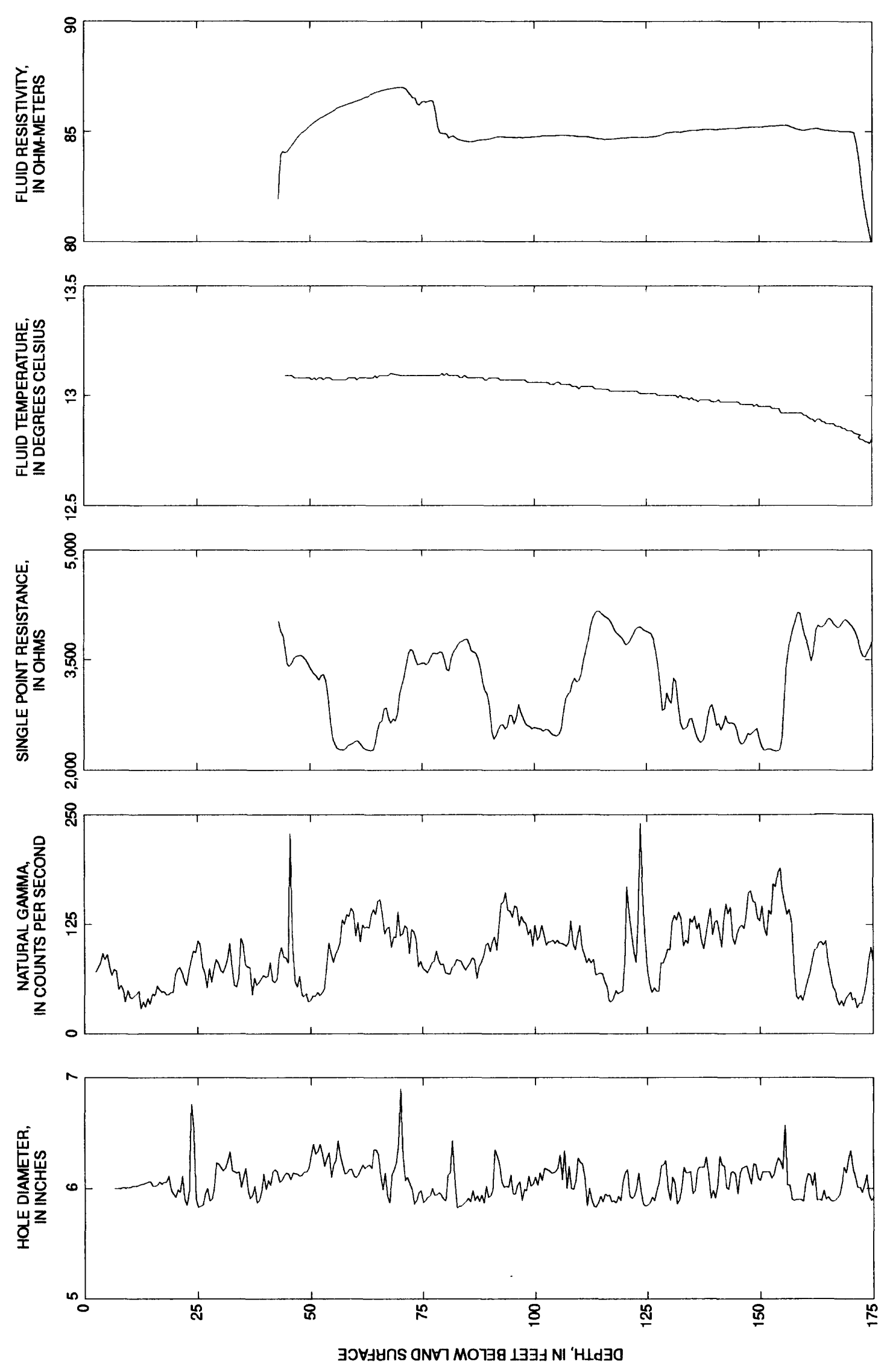

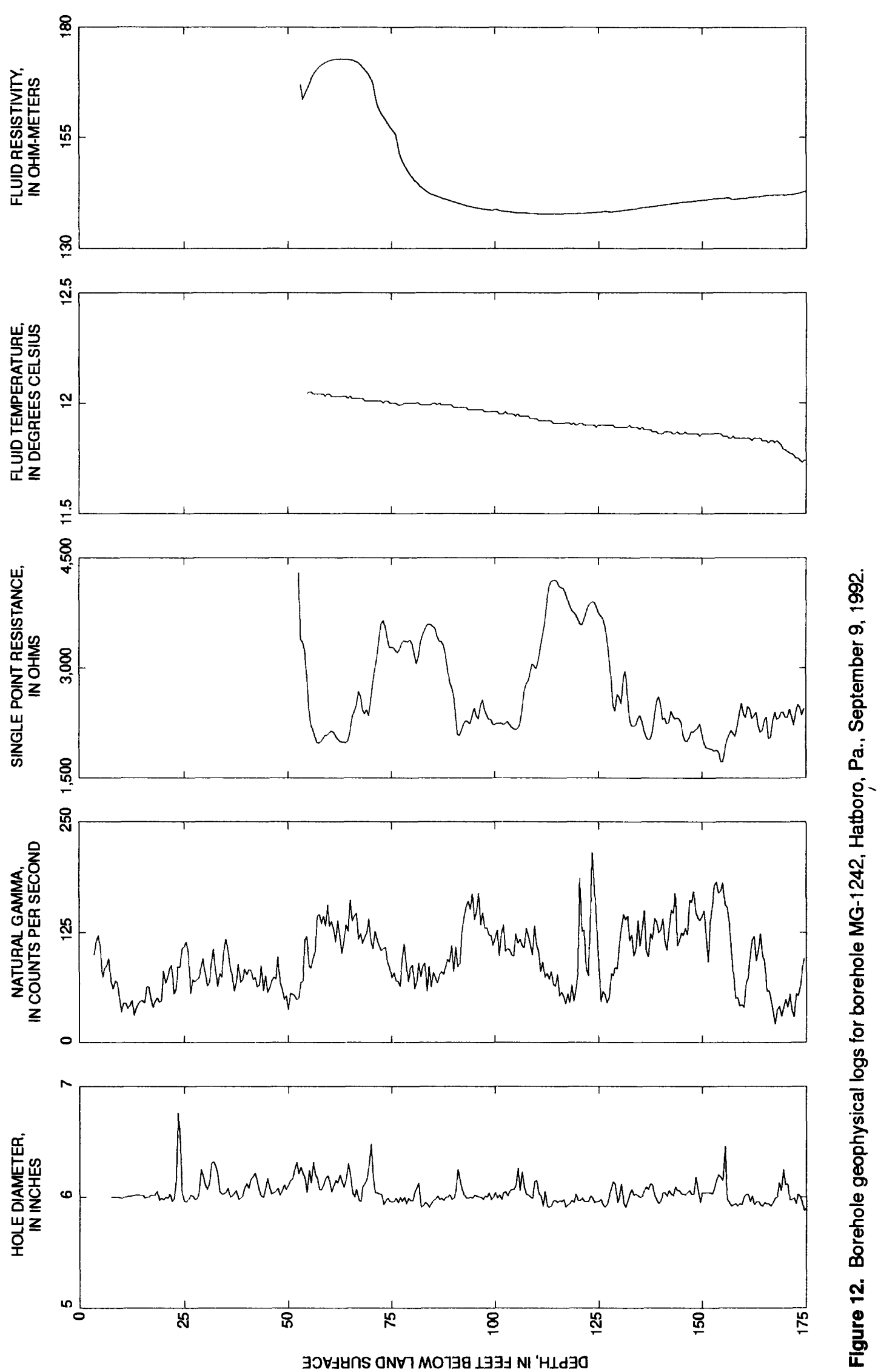

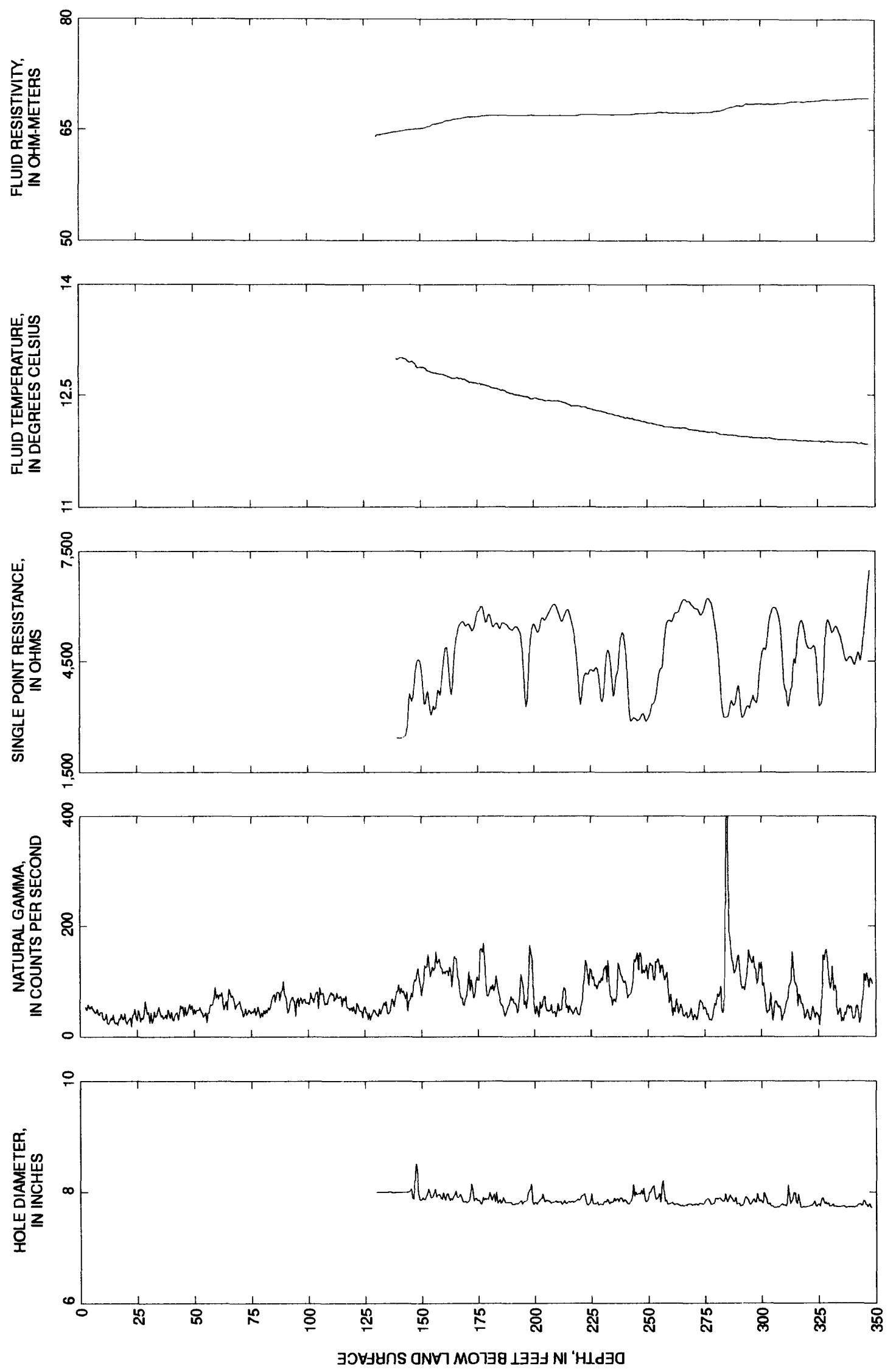

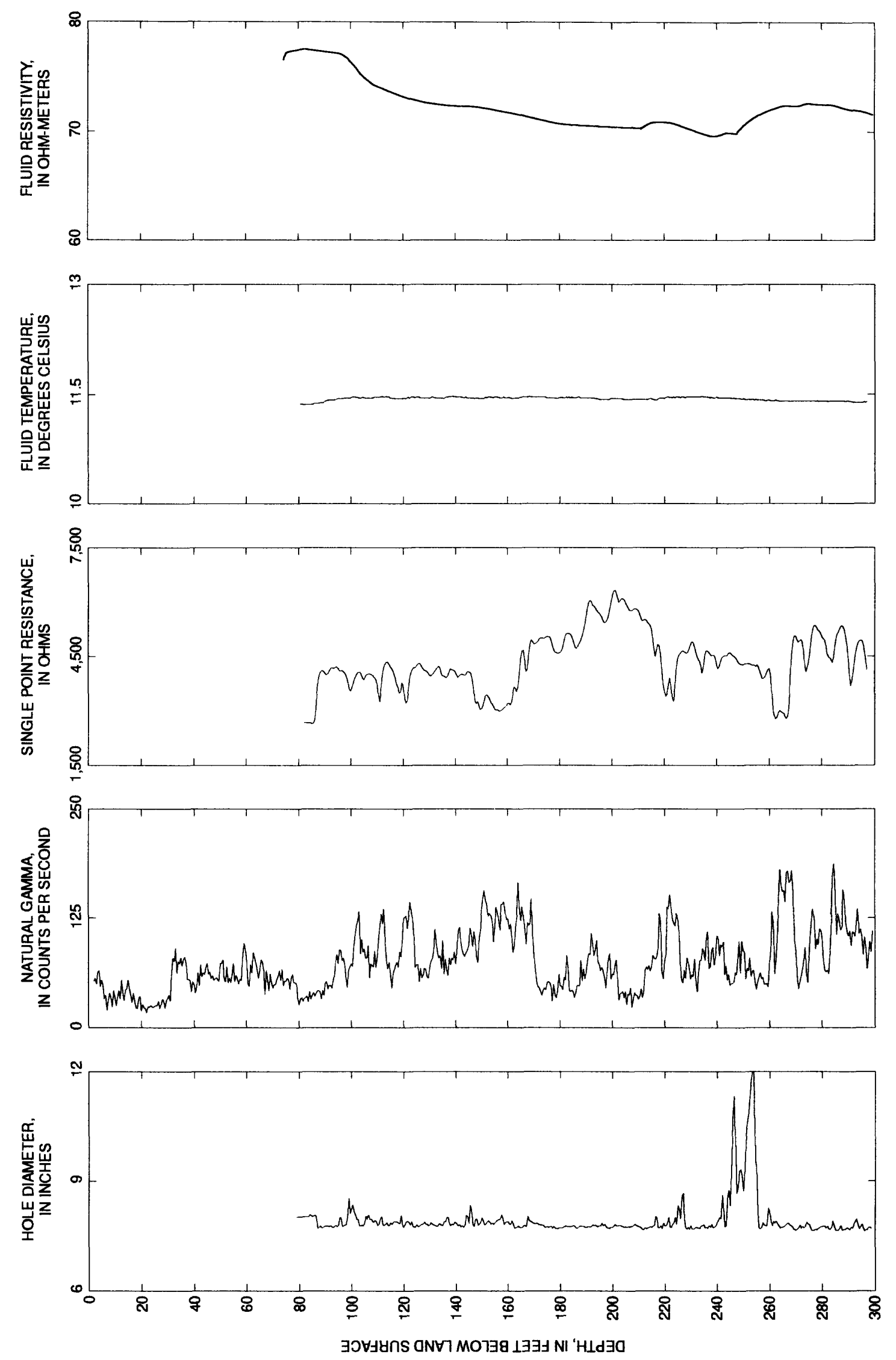

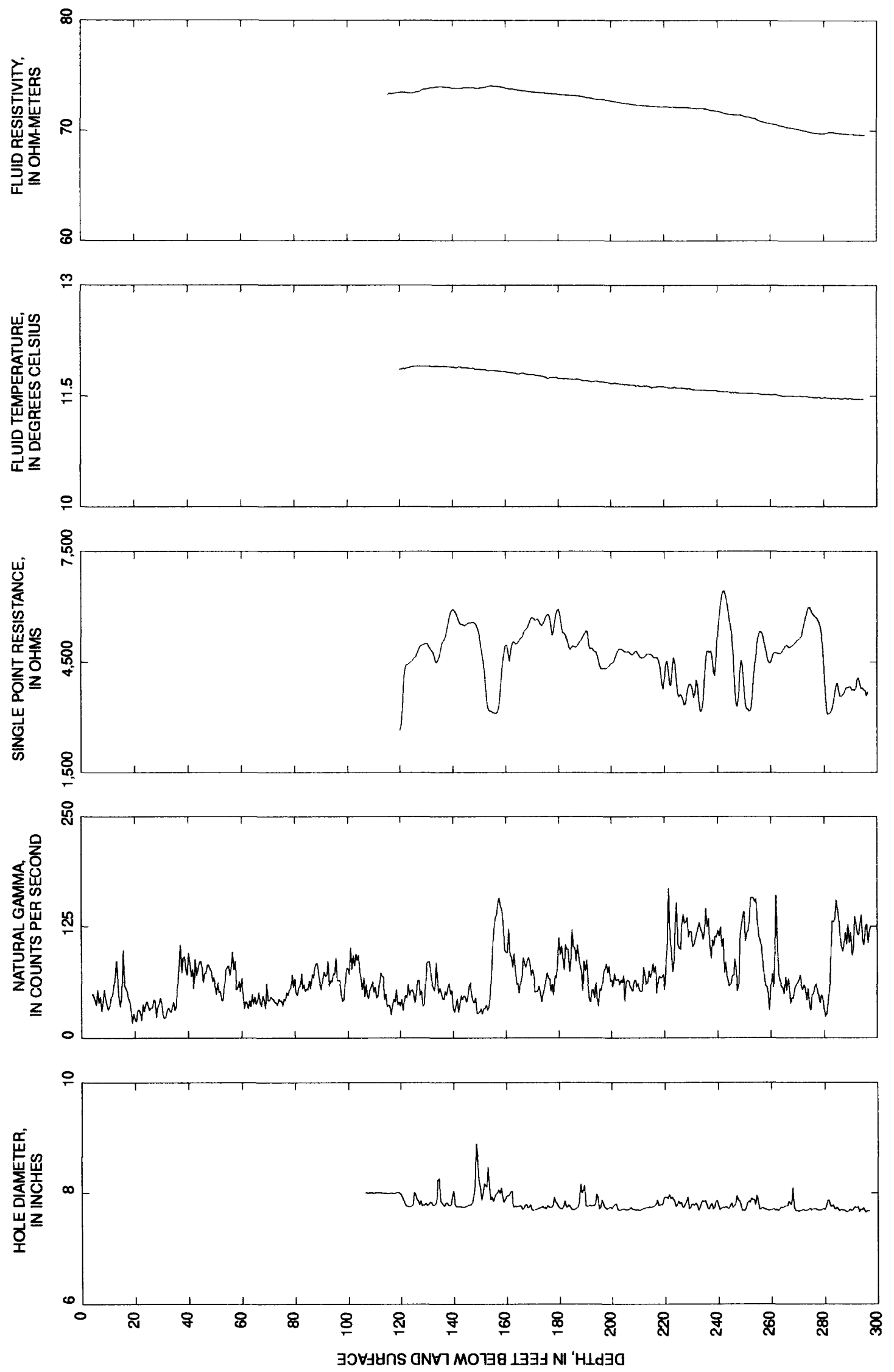

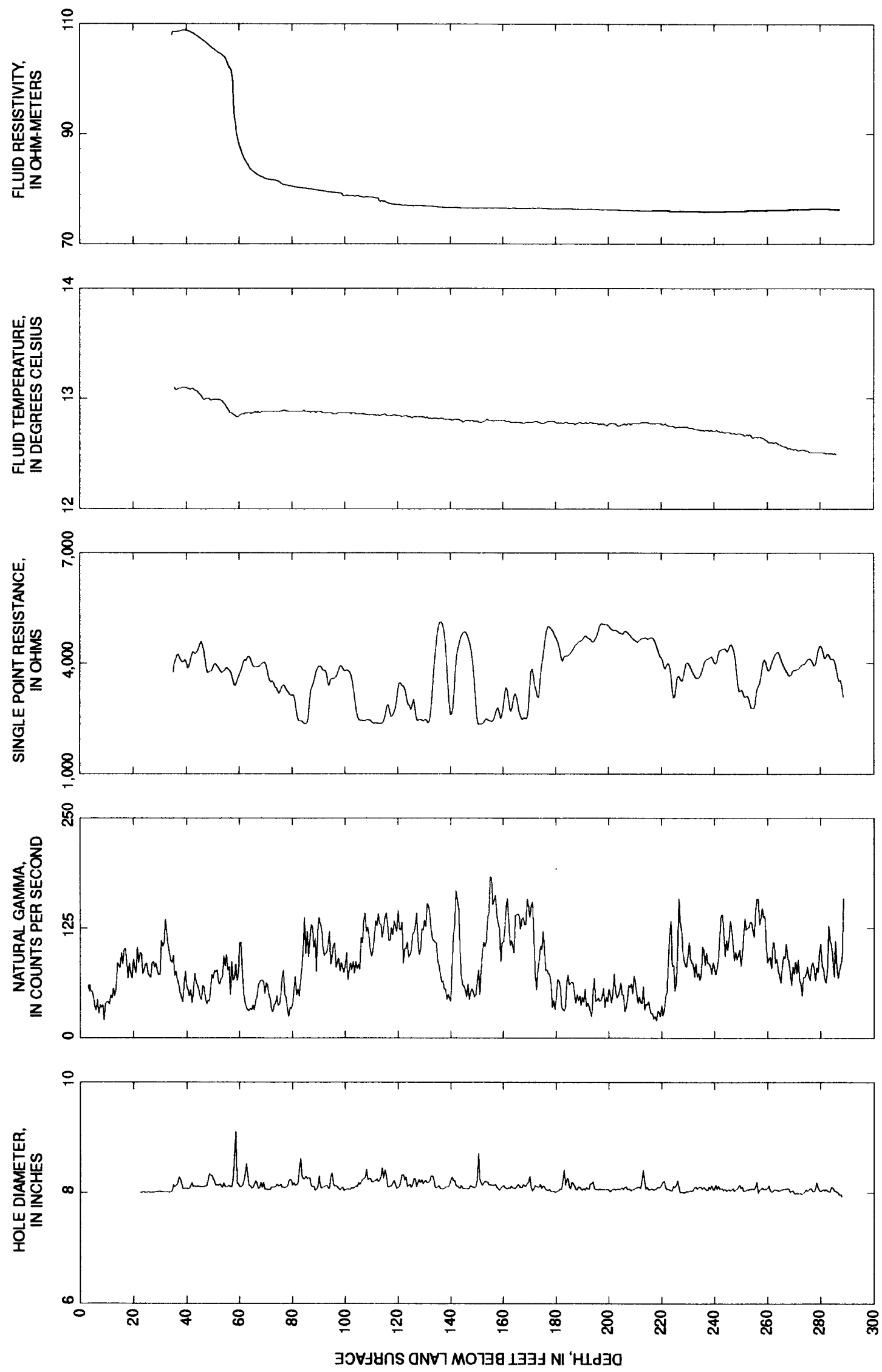

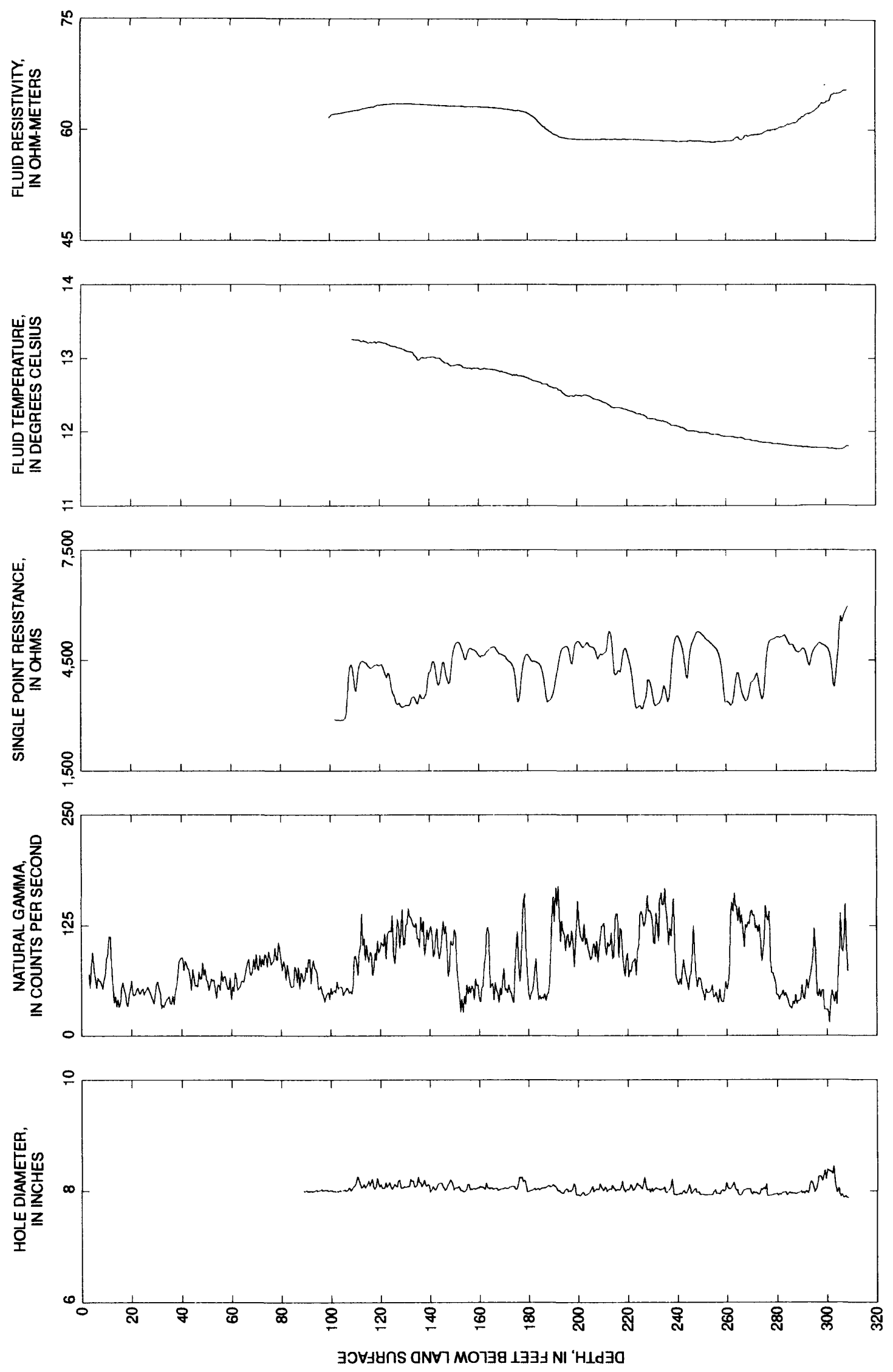

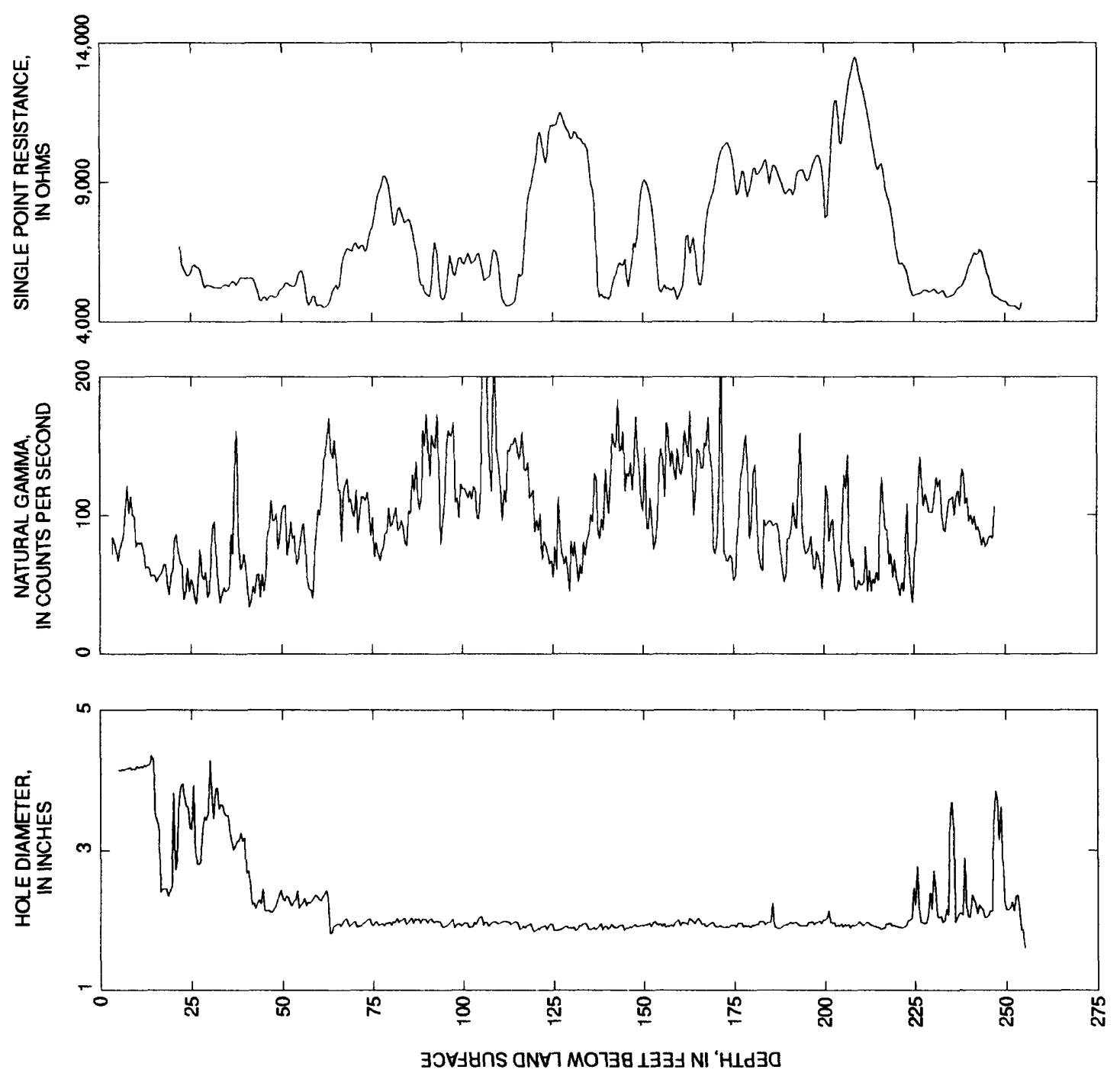

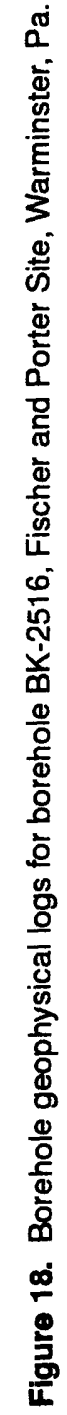



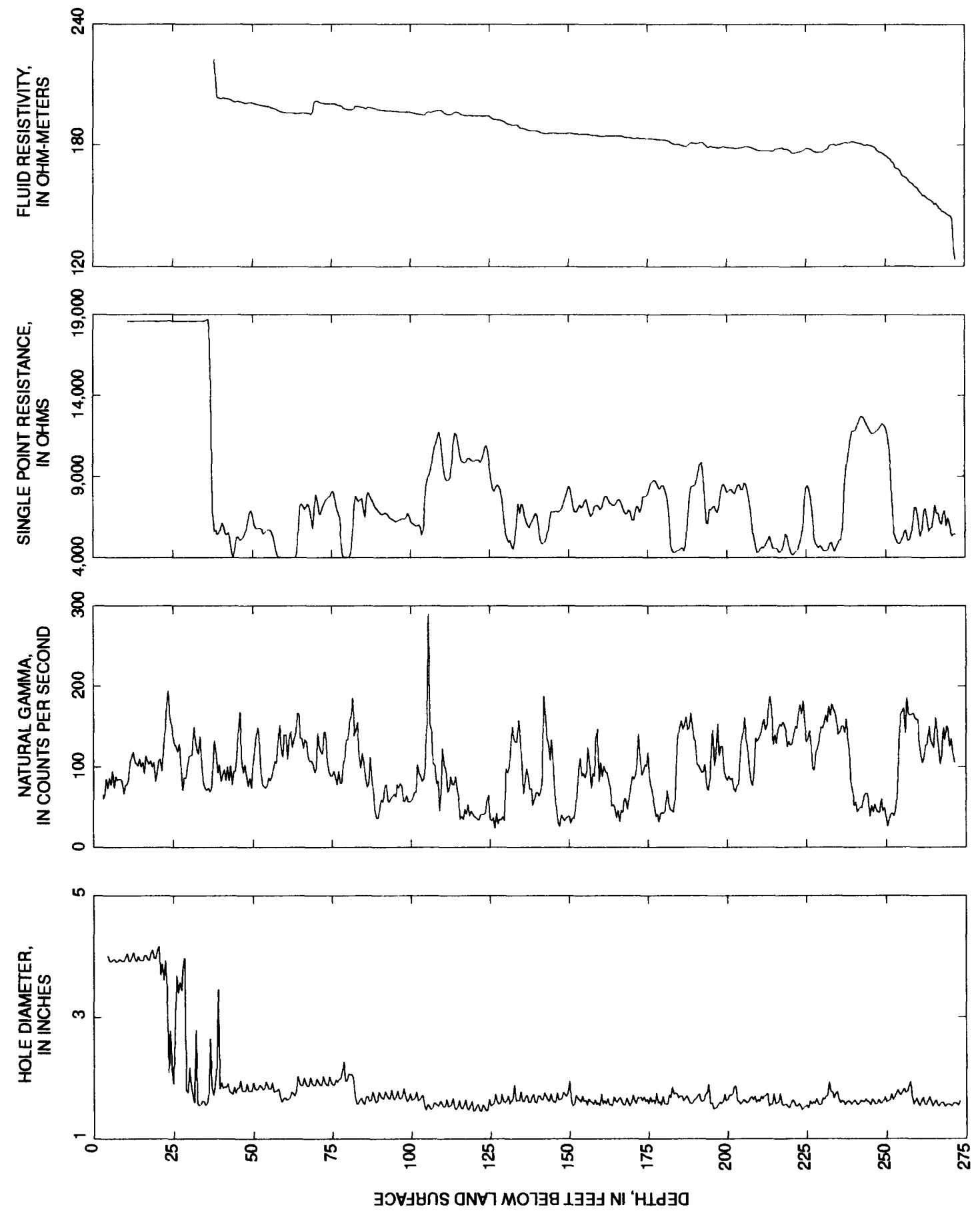


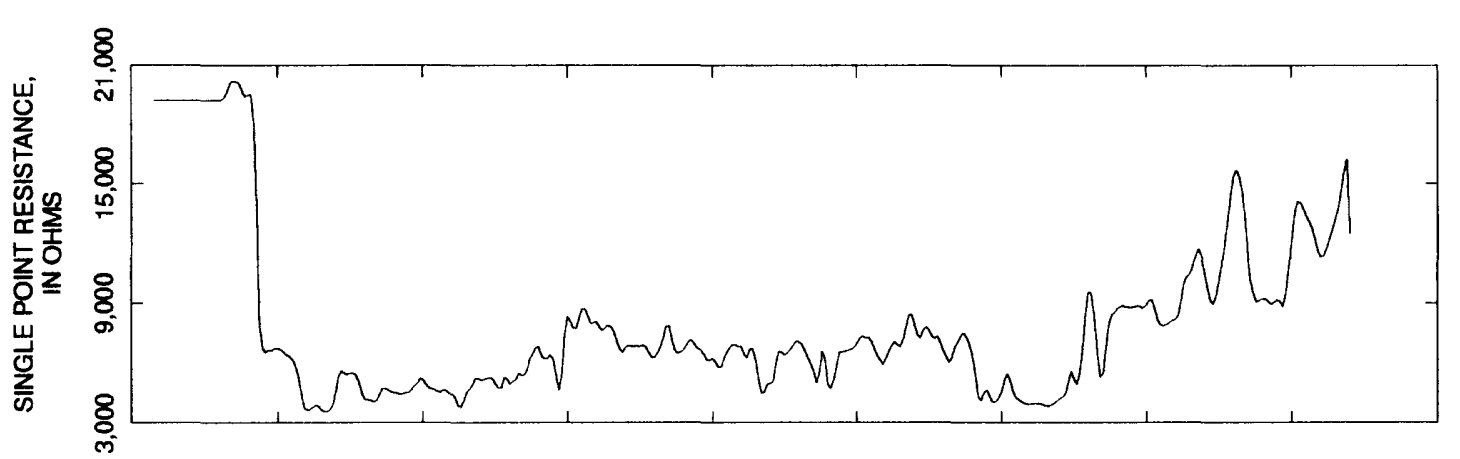

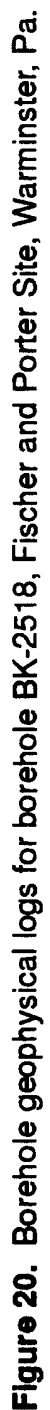




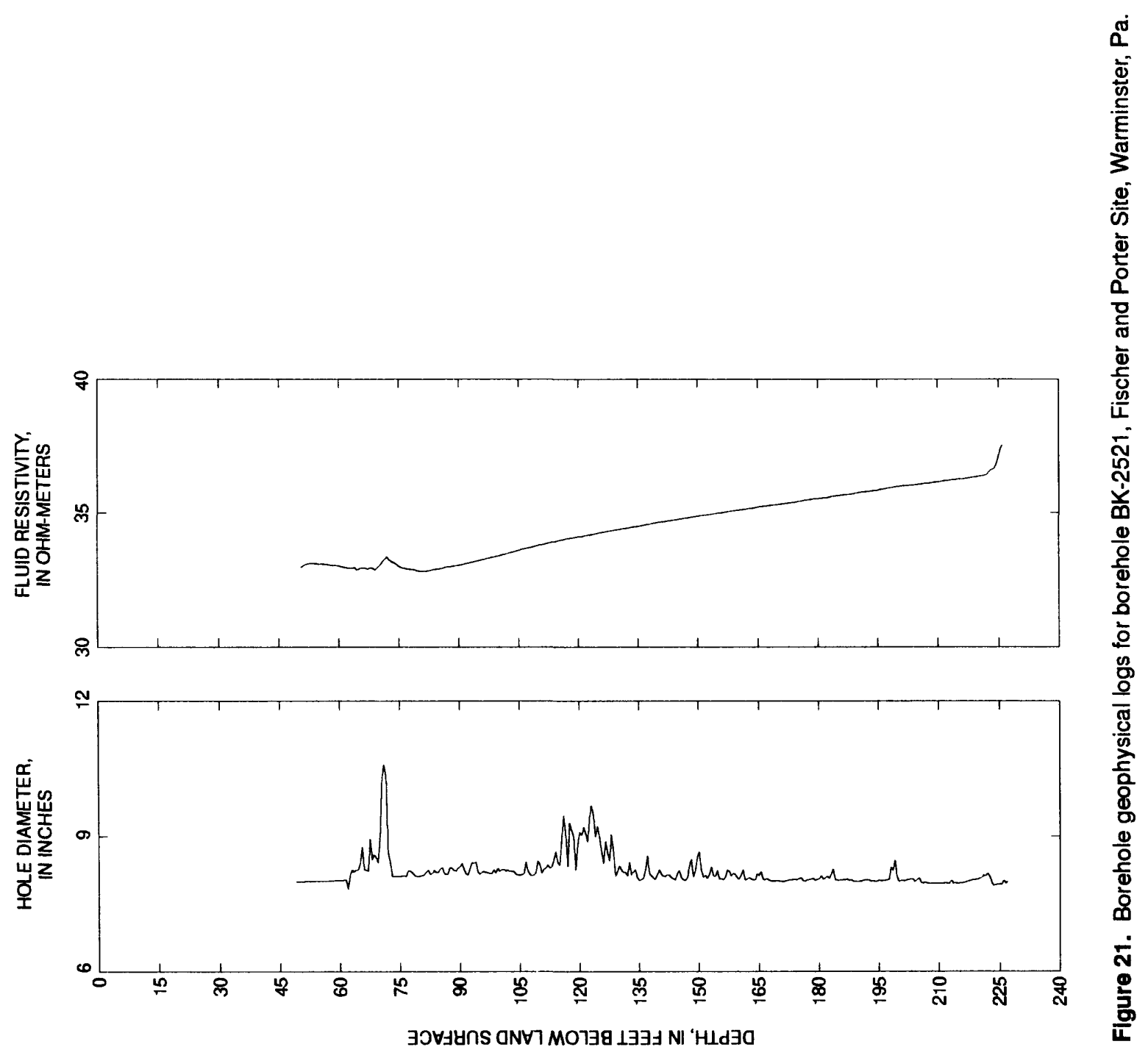



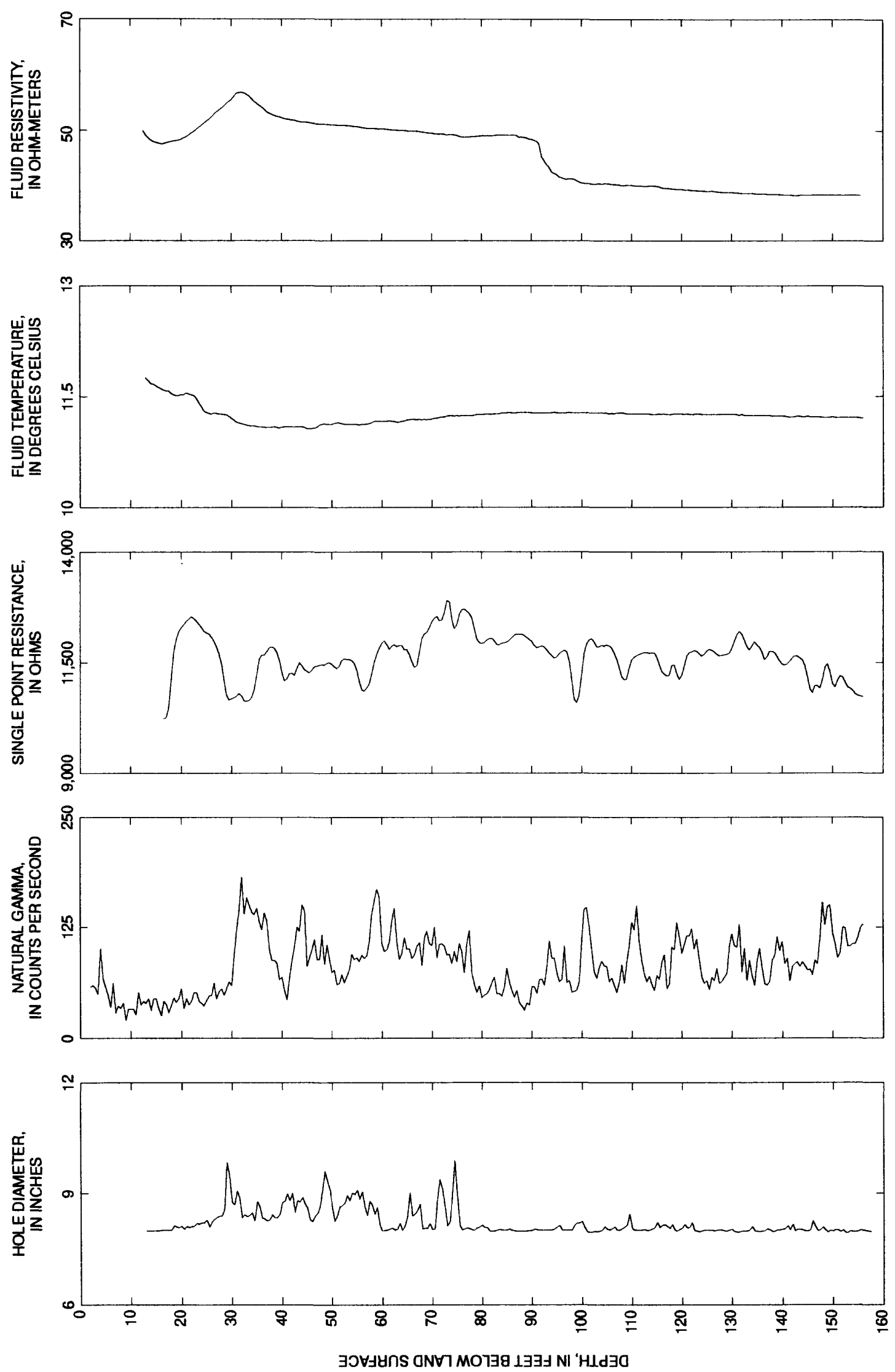

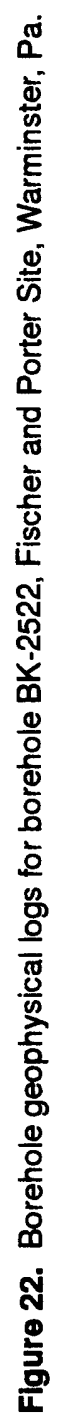




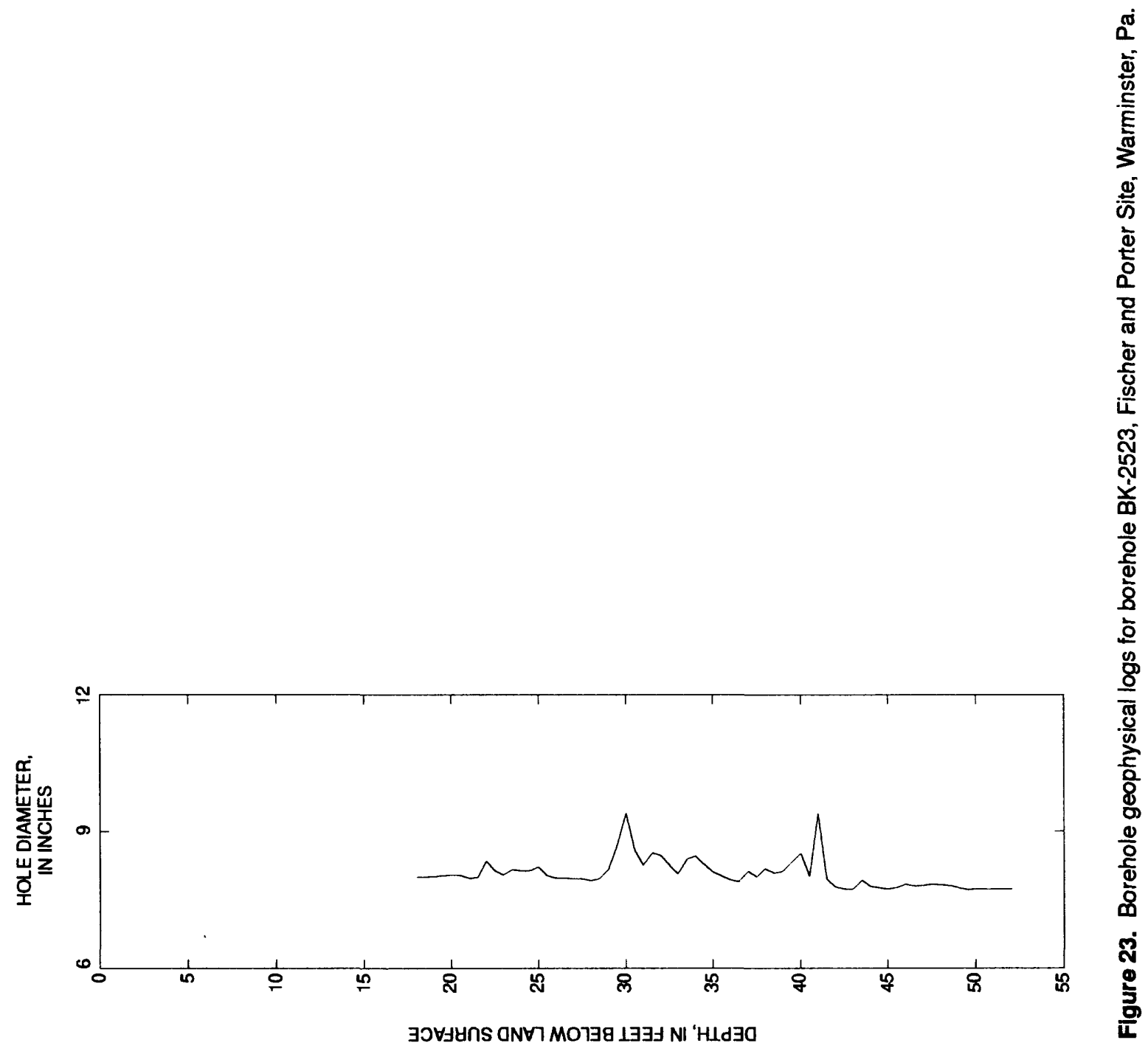



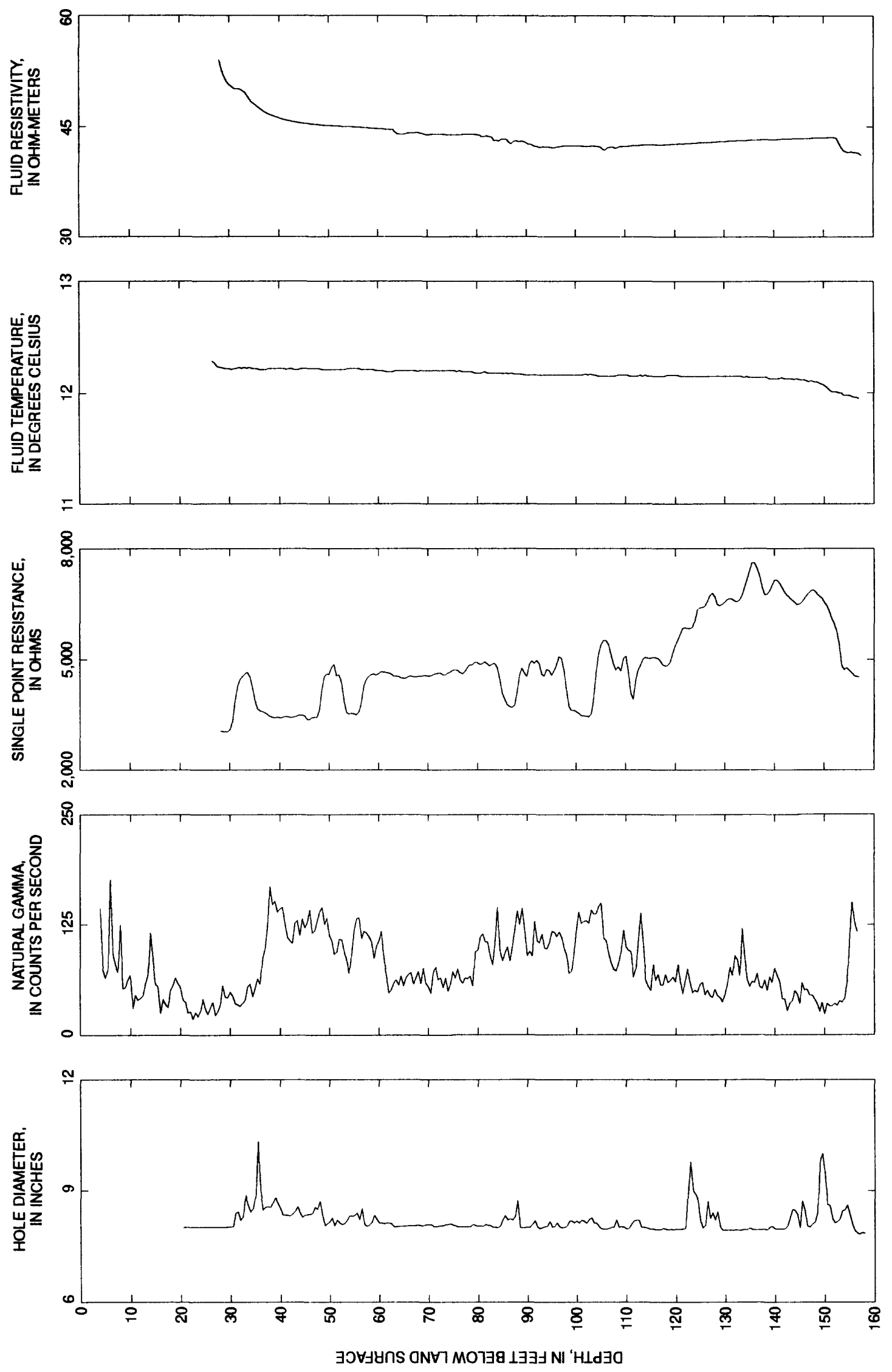

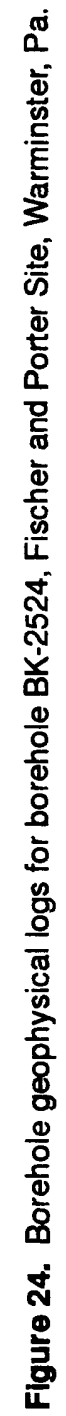



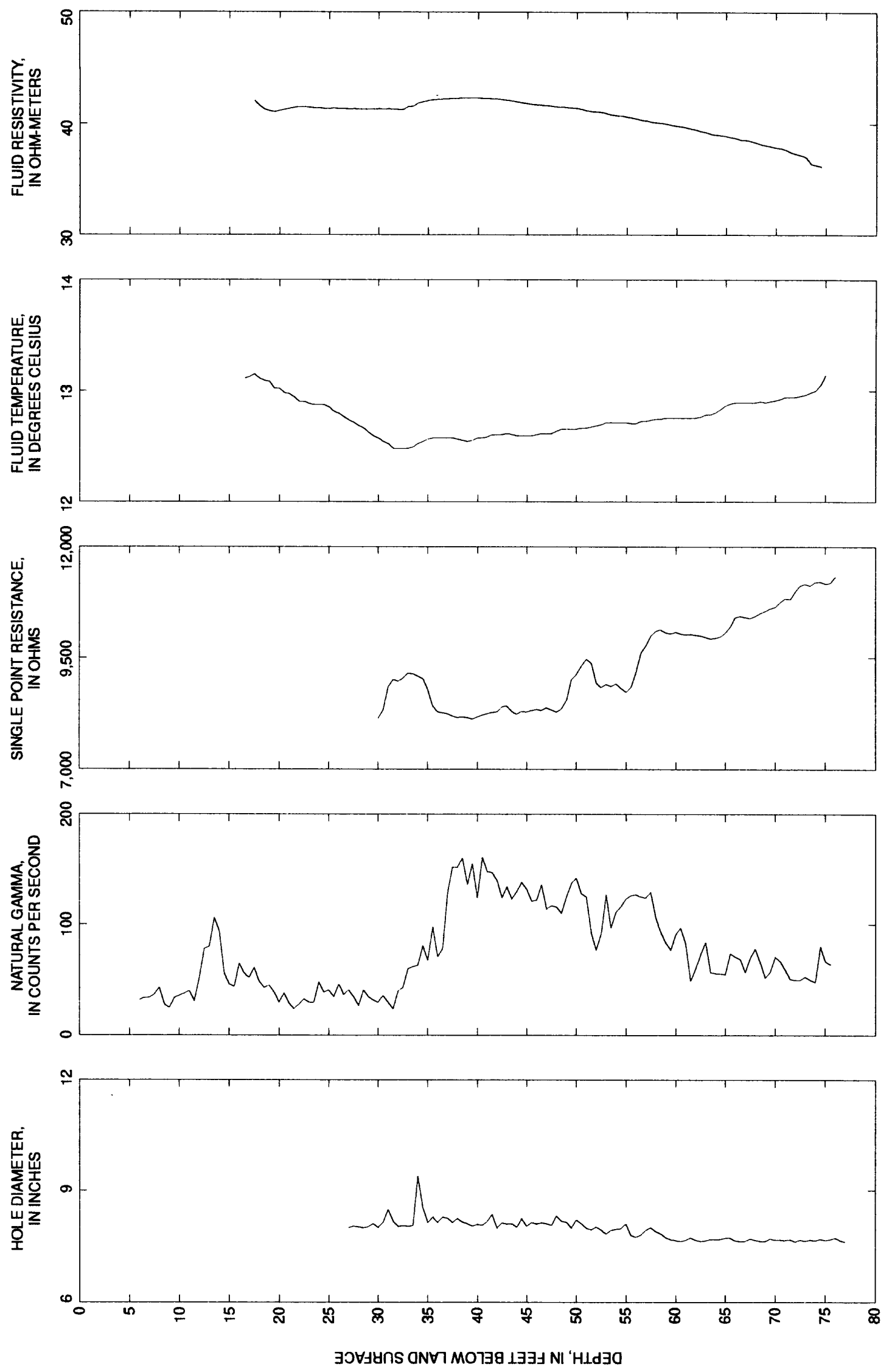

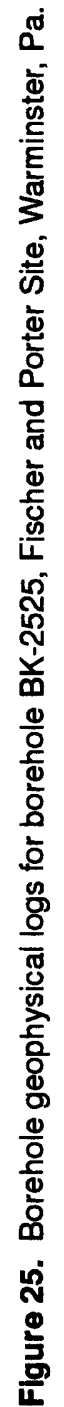




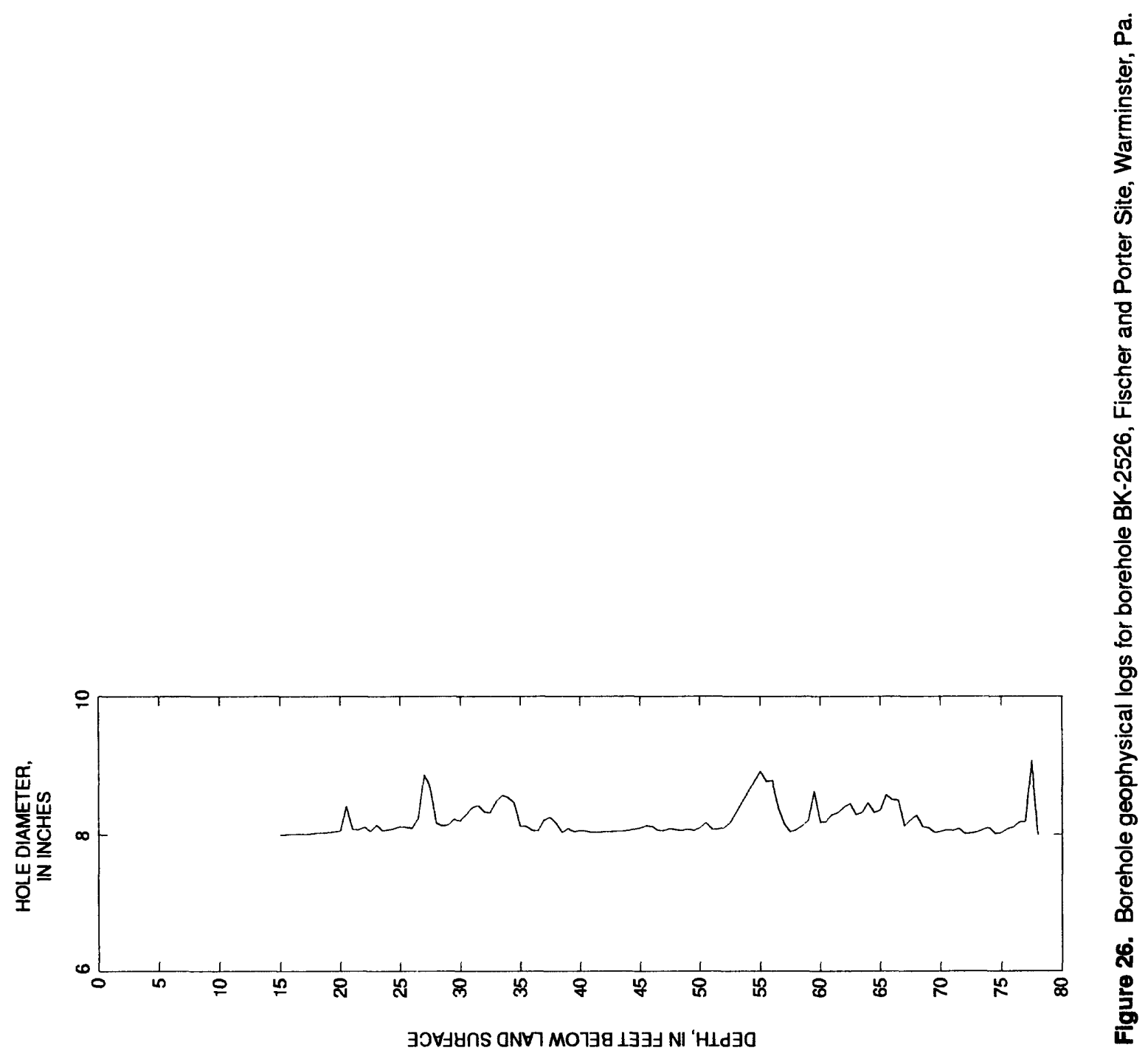



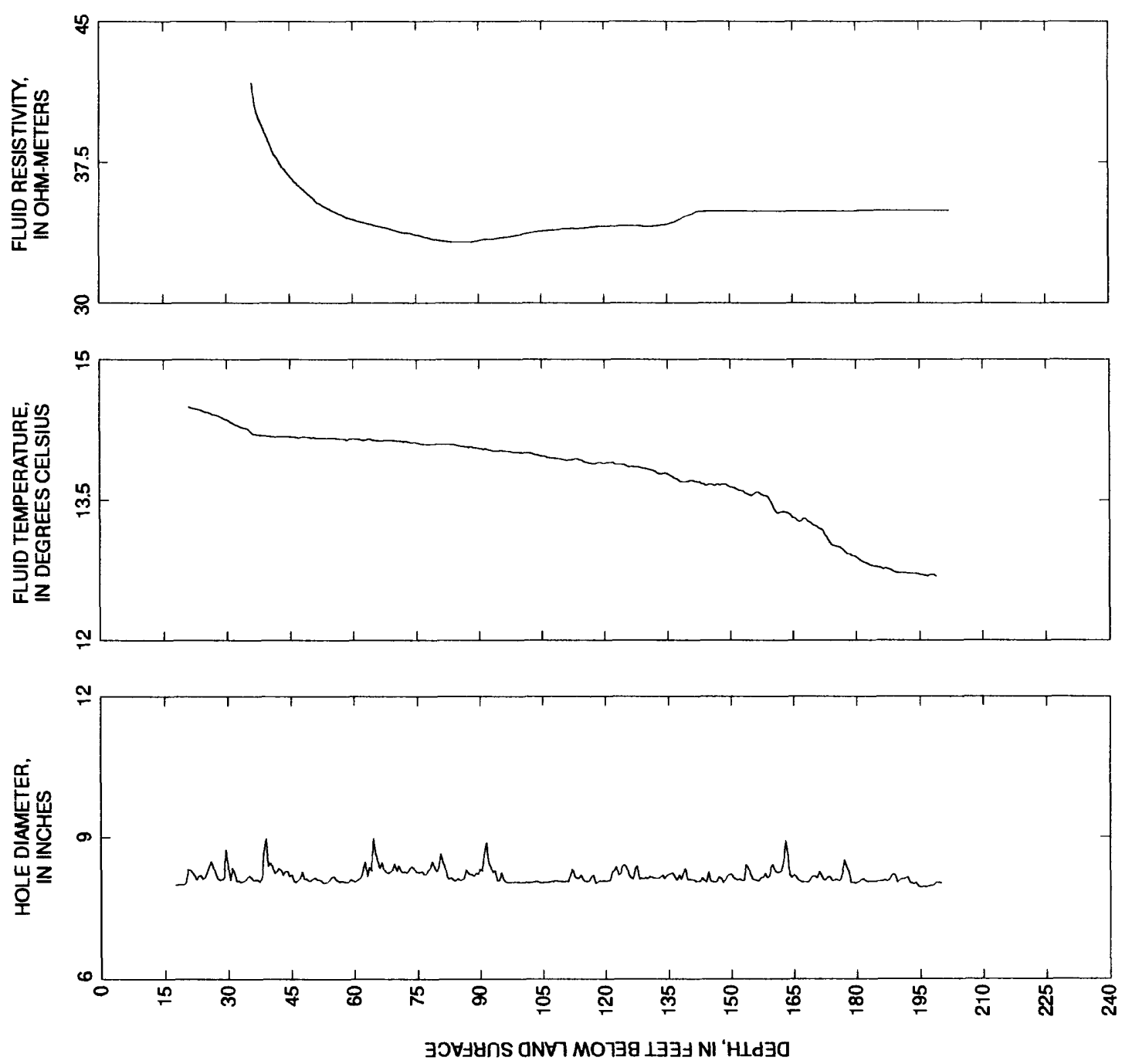


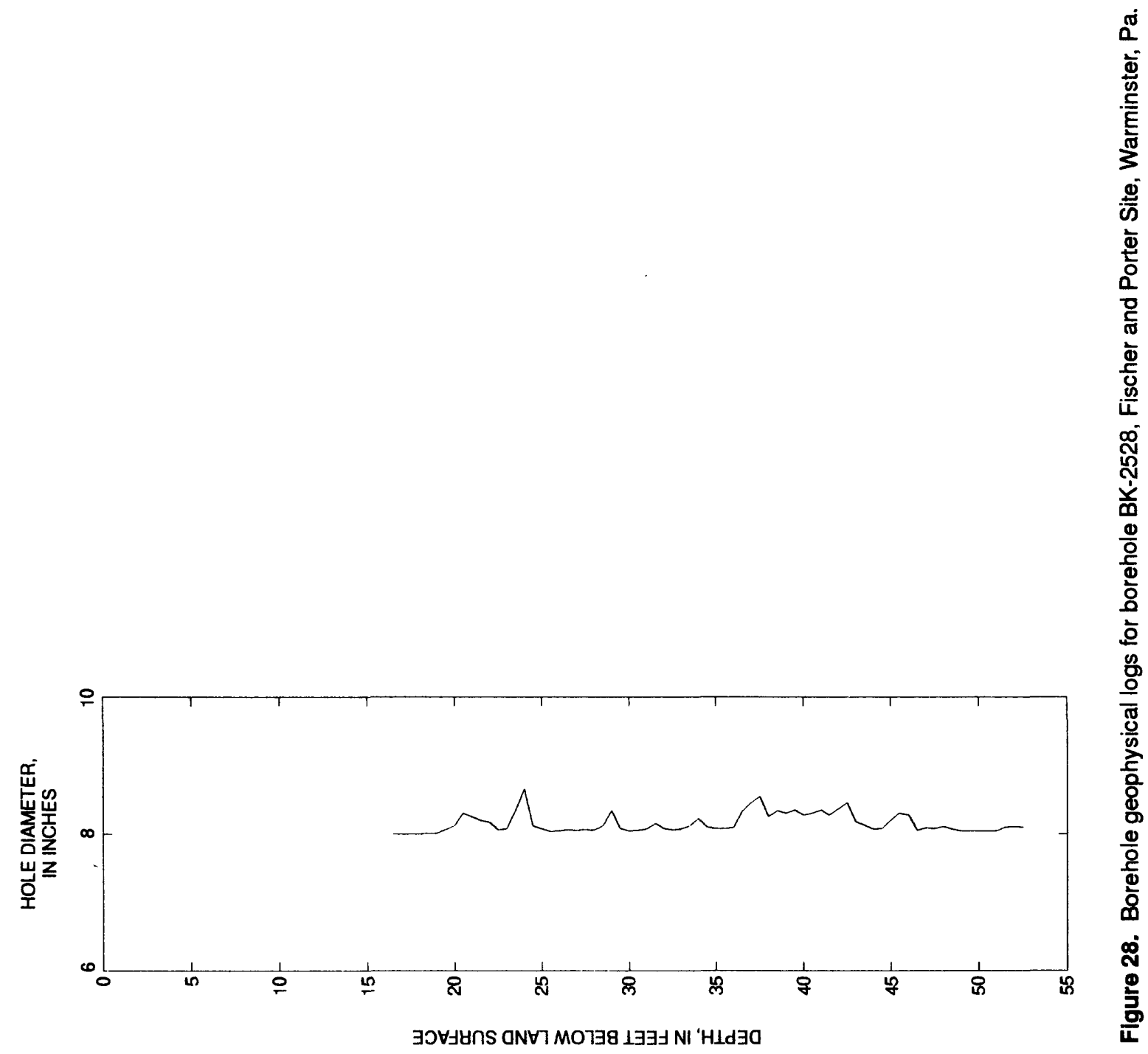


Table 1. Geologic log of rock core from corehole BK-2516, Fischer and Porter Site, Warminster, $\mathrm{Pa}$.

\begin{tabular}{|c|c|}
\hline $\begin{array}{l}\text { Depth, in feet } \\
\text { below land surface }\end{array}$ & Description \\
\hline $15.46-29.7$ & Light gray-white, fine-grained sandstone \\
\hline 29.7-30.9 & Gray, poorly sorted, medium- to fine-grained sandstone \\
\hline $30.9-42.0$ & Light gray, fine-grained sandstone \\
\hline \multicolumn{2}{|l|}{ Gradational contact } \\
\hline $42.0-44.0$ & Light gray, poorly sorted, medium-grained sandstone with silt blebs \\
\hline $44.0-44.5$ & Light gray, fine-grained sandstone \\
\hline 44.5-55.3 & Light purple-gray, silty, fine-grained sandstone \\
\hline \multicolumn{2}{|l|}{ Gradational contact } \\
\hline $55.3-60.1$ & Light gray, fine-grained sandstone \\
\hline $60.1-66.43$ & Red-brown siltstone \\
\hline 66.43-72.43 & Light purple, silty, fine-grained sandstone \\
\hline \multicolumn{2}{|l|}{ Gradational contact } \\
\hline 74.43-80.75 & Light gray, fine-grained, micaceous sandstone \\
\hline $80.75-82.0$ & Light gray, fine-grained sandstone \\
\hline $82.0-86.6$ & Light gray, poorly sorted, medium- to fine-grained sandstone \\
\hline $86.6-88.85$ & $\begin{array}{l}\text { Transitional unit - mix of thin siltstone beds with light gray, medium- to } \\
\text { fine-grained, poorly sorted sandstone with silt blebs }\end{array}$ \\
\hline $88.85-92.6$ & Red-brown siltstone \\
\hline $92.6-94.68$ & Light purple-gray, silty, fine-grained sandstone \\
\hline 94.68-95.75 & Red-brown siltstone \\
\hline $95.75-96.0$ & Light gray, fine-grained sandstone \\
\hline $96.0-97.08$ & Red-brown siltstone \\
\hline $97.08-100.08$ & Light purple-gray, silty, fine-grained siltstone \\
\hline $100.08-104.08$ & Dark gray, banded, silty, fine-grained, micaceous sandstone \\
\hline $104.08-106.08$ & Green and light gray, banded, fine-grained sandstone \\
\hline $106.08-108.4$ & Light gray, fine-grained sandstone \\
\hline 108.4-117.88 & Red-brown siltstone \\
\hline $117.88-119.04$ & Light purple-gray, silty, fine-grained sandstone \\
\hline $119.04-139.05$ & Light gray, fine-grained sandstone \\
\hline $139.05-144.28$ & Red-brown siltstone \\
\hline \multicolumn{2}{|l|}{ Gradational contact } \\
\hline $144.28-149.28$ & Light red-brown, micaceous siltstone \\
\hline $149.28-155.12$ & Purple-gray, silty, fine-grained sandstone \\
\hline $155.12-161.61$ & Red-brown siltstone \\
\hline \multicolumn{2}{|l|}{ Gradational contact } \\
\hline $161.61-162.0$ & "Banded" bed \\
\hline \multicolumn{2}{|l|}{ Gradational contact } \\
\hline $162.0-163.0$ & Red-brown siltstone \\
\hline $163.0-164.33$ & "Banded" bed \\
\hline
\end{tabular}


Table 1. Geologic log of rock core from corehole BK-2516, Fischer and Porter Site,

Warminster, Pa.-Continued

\begin{tabular}{cl}
\hline $\begin{array}{c}\text { Depth, in feet } \\
\text { below land surface }\end{array}$ & \multicolumn{1}{c}{ Description } \\
\hline $164.33-164.52$ & Dark red-brown siltstone \\
$164.52-165.6$ & "Banded" bed \\
$165.6-165.85$ & Light brown, coarse-grained, poorly sorted conglomerate \\
$165.85-166.2$ & "Banded" unit (sandier than above) \\
$166.2-168.2$ & Dark red-brown siltstone \\
Gradational contact & \\
$168.2-176.5$ & Light gray, fine-grained sandstone \\
Gradational contact & \\
$176.5-178.5$ & Light gray, medium- to very fine-grained, poorly sorted sandstone with \\
& siltstone inclusions \\
$178.5-180.0$ & Dark gray, very fine-grained sandstone to silty, very fine-grained sandstone \\
$180.0-182.58$ & Light gray, course- to very fine-grained, poorly sorted sandstone with \\
& siltstone inclusions \\
$182.58-187.25$ & Purple-gray, silty, fine-grained sandstone \\
Gradational contact & \\
$187.25-188.0$ & Light gray, fine-grained sandstone, weathered \\
$188.0-225.5$ & Light gray, fine-grained sandstone \\
$225.5-239.9$ & Dark red-brown siltstone \\
$239.9-246.44$ & Purple-gray, fine-grained sandstone \\
$246.44-247.6$ & Light red-brown "banded" bed \\
$247.6-261.70$ & Red-brown siltstone \\
\hline &
\end{tabular}


Table 2. Geologic log of rock core from corehole BK-2517, Fischer and Porter Site, Warminster, Pa.

\begin{tabular}{|c|c|}
\hline $\begin{array}{l}\text { Depth, in feet } \\
\text { below land surface }\end{array}$ & Description \\
\hline $19.0-24.0$ & Red-brown siltstone \\
\hline $24.0-27.4$ & Dark purple-brown, micaceous siltstone \\
\hline 29.0-29.5 & Red-brown siltstone \\
\hline $29.5-37.5$ & Light brownish-gray, fine-grained sandstone \\
\hline $37.5-39.0$ & No recovery \\
\hline $39.0-43.0$ & Light gray, very fine- to fine-grained sandstone \\
\hline $43.0-44.0$ & No recovery \\
\hline $44.0-45.8$ & Light pinkish-gray, fine-grained sandstone \\
\hline $45.8-45.9$ & Dark purple-gray, micaceous siltstone \\
\hline $45.9-46.0$ & Red-brown siltstone \\
\hline $46.0-46.8$ & No recovery \\
\hline $46.8-61.3$ & Dark purple-gray, micaceous siltstone \\
\hline $61.3-62.5$ & Light gray, medium- to coarse-grained sandstone and conglomerate \\
\hline 62.5-69.0 & Red-brown siltstone, abundant caliche \\
\hline $69.0-73.0$ & Dark purplish red-brown, micaceous siltstone \\
\hline 73.0-73.1 & Red-brown siltstone \\
\hline 73.1-75.5 & Dark purplish red-brown, micaceous siltstone \\
\hline \multicolumn{2}{|l|}{ Gradational contact } \\
\hline 75.5-76.5 & Purple-gray, very fine-grained sandstone (some micaceous) \\
\hline $76.5-77.0$ & Light gray, fine-grained sandstone \\
\hline $77.0-79.0$ & Dark purple-gray, very fine-grained sandstone, weathered \\
\hline $79.0-83.6$ & Red-brown siltstone \\
\hline $83.6-85.6$ & Dark purple-gray siltstone \\
\hline $85.6-87.5$ & Dark purple-gray, micaceous siltstone \\
\hline $87.5-90.0$ & Dark gray, very fine-grained sandstone, weathered \\
\hline $90.0-94.9$ & Light gray, very fine-grained sandstone \\
\hline $94.9-101.0$ & Light gray, fine-grained sandstone \\
\hline \multicolumn{2}{|l|}{ Gradational contact } \\
\hline $101.0-108.2$ & Light gray, medium-grained sandstone, poorly sorted \\
\hline 108.2-109.7 & Light gray, medium- to fine-grained sandstone \\
\hline 109.7-109.8 & Light gray, poorly sorted, coarse- to fine-grained sandstone \\
\hline $109.8-114.5$ & Light gray, fine-grained sandstone \\
\hline $114.5-115.0$ & $\begin{array}{l}\text { Light gray, fine-grained sandstone grading to medium-grained sandstone, } \\
\text { weathered }\end{array}$ \\
\hline \multicolumn{2}{|l|}{ Gradational contact } \\
\hline $115.0-123.0$ & Light gray conglomerate \\
\hline $123.0-124.5$ & Light gray, fine-grained sandstone \\
\hline $124.5-127.9$ & Conglomerate and coarse-grained sandstone \\
\hline $127.9-129.2$ & Light gray, medium-grained sandstone, weathered \\
\hline
\end{tabular}


Table 2. Geologic log of rock core from corehole BK-2517, Fischer and Porter Site, Warminster, Pa.-Continued

\begin{tabular}{|c|c|}
\hline $\begin{array}{l}\text { Depth, in feet } \\
\text { below land surface }\end{array}$ & Description \\
\hline $129.2-130.8$ & Dark charcoal-gray to dark gray, micaceous siltstone \\
\hline \multicolumn{2}{|l|}{ Gradational contact } \\
\hline $130.8-134.5$ & Red-brown siltstone \\
\hline $134.5-135.7$ & Light purple-gray, silty, very fine-grained sandstone \\
\hline \multicolumn{2}{|l|}{ Gradational contact } \\
\hline $135.7-136.6$ & Dark purple-gray siltstone \\
\hline $136.6-140.0$ & Light purple-gray, silty, very fine-grained sandstone \\
\hline \multicolumn{2}{|l|}{ Gradational contact } \\
\hline $140.0-141.9$ & Light gray, fine-grained sandstone \\
\hline $141.9-144.0$ & Light purple-gray, silty, fine-grained sandstone \\
\hline $144.0-144.3$ & Red-brown siltstone \\
\hline $144.3-145.0$ & Light purple-gray, silty, fine-grained sandstone \\
\hline $145.0-152.3$ & Light gray, medium- to fine-grained sandstone \\
\hline \multicolumn{2}{|l|}{ Gradational contact } \\
\hline $152.3-152.8$ & Light gray, poorly sorted, coarse-grained sandstone \\
\hline \multicolumn{2}{|l|}{ Gradational contact } \\
\hline $152.8-155.2$ & $\begin{array}{l}\text { Light gray, fine-grained sandstone with some thin beds of light gray, } \\
\text { medium-grained sandstone }\end{array}$ \\
\hline $155.2-158.8$ & Light gray, poorly sorted, coarse- to medium-grained sandstone \\
\hline 158.8-170.75 & Light gray, fine-grained sandstone \\
\hline $170.75-172.1$ & Dark red-brown siltstone \\
\hline 172.1-173.7 & Purple-gray, silty, fine-grained sandstone \\
\hline $173.7-175.0$ & Gray, poorly sorted, coarse-grained sandstone \\
\hline \multicolumn{2}{|l|}{ Gradational contact } \\
\hline $175.0-183.5$ & Light gray, fine-grained sandstone \\
\hline $183.5-188.6$ & Red-brown siltstone \\
\hline $188.6-189.3$ & Light gray, very fine-grained sandstone \\
\hline $189.3-189.8$ & Dark gray, fine-grained sandstone \\
\hline 189.8-195.4 & Light gray, fine-grained sandstone \\
\hline 195.4-195.6 & Dark green siltstone \\
\hline 195.6-197.8 & Light gray, fine-grained sandstone \\
\hline \multicolumn{2}{|l|}{ Gradational contact } \\
\hline $197.8-205.0$ & Purple-gray, silty, fine-grained sandstone \\
\hline \multicolumn{2}{|l|}{ Gradational contact } \\
\hline 205.0-209.8 & Light purple-gray, fine-grained sandstone \\
\hline 209.8-235.92 & Red-brown siltstone \\
\hline 235.92-238 & Dark brown, micaceous siltstone \\
\hline $238-253.25$ & Light gray, fine-grained sandstone \\
\hline $253.25-277.2$ & Red-brown siltstone \\
\hline
\end{tabular}


Table 3. Geologic log of rock core from corehole BK-2518, Fischer and Porter Site, Warminster, Pa.

\begin{tabular}{|c|c|}
\hline $\begin{array}{l}\text { Depth, in feet } \\
\text { below land surface }\end{array}$ & Description \\
\hline $9.8-10.7$ & Light gray, fine-grained sandstone \\
\hline $10.7-15.0$ & Light gray, very fine-grained sandstone \\
\hline $15.0-15.33$ & $\begin{array}{l}\text { Light gray, poorly sorted, medium- to coarse-grained sandstone and } \\
\text { conglomerate }\end{array}$ \\
\hline $15.33-16.40$ & Light gray, fine-grained sandstone \\
\hline $16.40-17.92$ & Gray, poorly sorted, coarse-grained sandstone and conglomerate \\
\hline $17.92-18.9$ & Light gray, fine-grained sandstone \\
\hline $18.9-25.43$ & Light gray, poorly sorted, coarse-grained sandstone and conglomerate \\
\hline $25.43-27.18$ & Light gray, medium to coarse-grained sandstone \\
\hline \multicolumn{2}{|l|}{ Gradational contact } \\
\hline $27.18-30.1$ & Light gray, fine-grained sandstone \\
\hline $30.1-36.4$ & Red-brown siltstone \\
\hline $36.4-37.73$ & Light purple-gray, silty, fine-grained sandstone \\
\hline $37.73-40.9$ & Light gray, fine-grained sandstone \\
\hline 40.9-50.17 & $\begin{array}{l}\text { Red-brown siltstone grading into dark purple-brown, silty, fine-grained } \\
\text { sandstone }\end{array}$ \\
\hline $50.17-51.3$ & Dark gray, micaceous, very fine-grained sandstone and siltstone \\
\hline $51.3-53.3$ & Light gray, very fine-grained sandstone \\
\hline $53.3-53.63$ & Dark gray, micaceous, very fine-grained sandstone and siltstone \\
\hline $53.63-55.5$ & Light purple-gray, silty, fine-grained sandstone \\
\hline \multicolumn{2}{|l|}{ Gradational contact } \\
\hline $55.5-61.88$ & Light gray, fine-grained sandstone \\
\hline $61.88-62.88$ & Red-brown siltstone \\
\hline $62.88-65.8$ & Dark gray, very fine-grained sandstone \\
\hline 65.8-69.55 & Light gray, fine-grained sandstone \\
\hline \multicolumn{2}{|l|}{ Gradational contact } \\
\hline 69.55-70.63 & Dark purple-brown siltstone \\
\hline 70.63-72.13 & Purple gray, silty, fine-grained sandstone \\
\hline \multicolumn{2}{|l|}{ Gradational contact } \\
\hline 72.13-72.88 & Dark gray, micaceous, very fine-grained sandstone and siltstone \\
\hline \multicolumn{2}{|l|}{ Gradational contact } \\
\hline 72.88-76.49 & Gray, very fine-grained sandstone \\
\hline $76.49-77.0$ & Light gray, fine-grained sandstone \\
\hline $77.0-77.66$ & $\begin{array}{l}\text { Light gray, poorly sorted, medium- to coarse-grained sandstone and } \\
\text { conglomerate }\end{array}$ \\
\hline $77.66-80.0$ & Light gray, fine- to very fine-grained sandstone \\
\hline \multicolumn{2}{|l|}{ Gradational contact } \\
\hline $80.0-80.6$ & Dark red-brown, micaceous siltstone \\
\hline $80.6-81.1$ & Dark gray, micaceous, very fine-grained sandstone \\
\hline
\end{tabular}


Table 3. Geologic log of rock core from corehole BK-2518, Fischer and Porter Site,

Warminster, Pa.-Continued

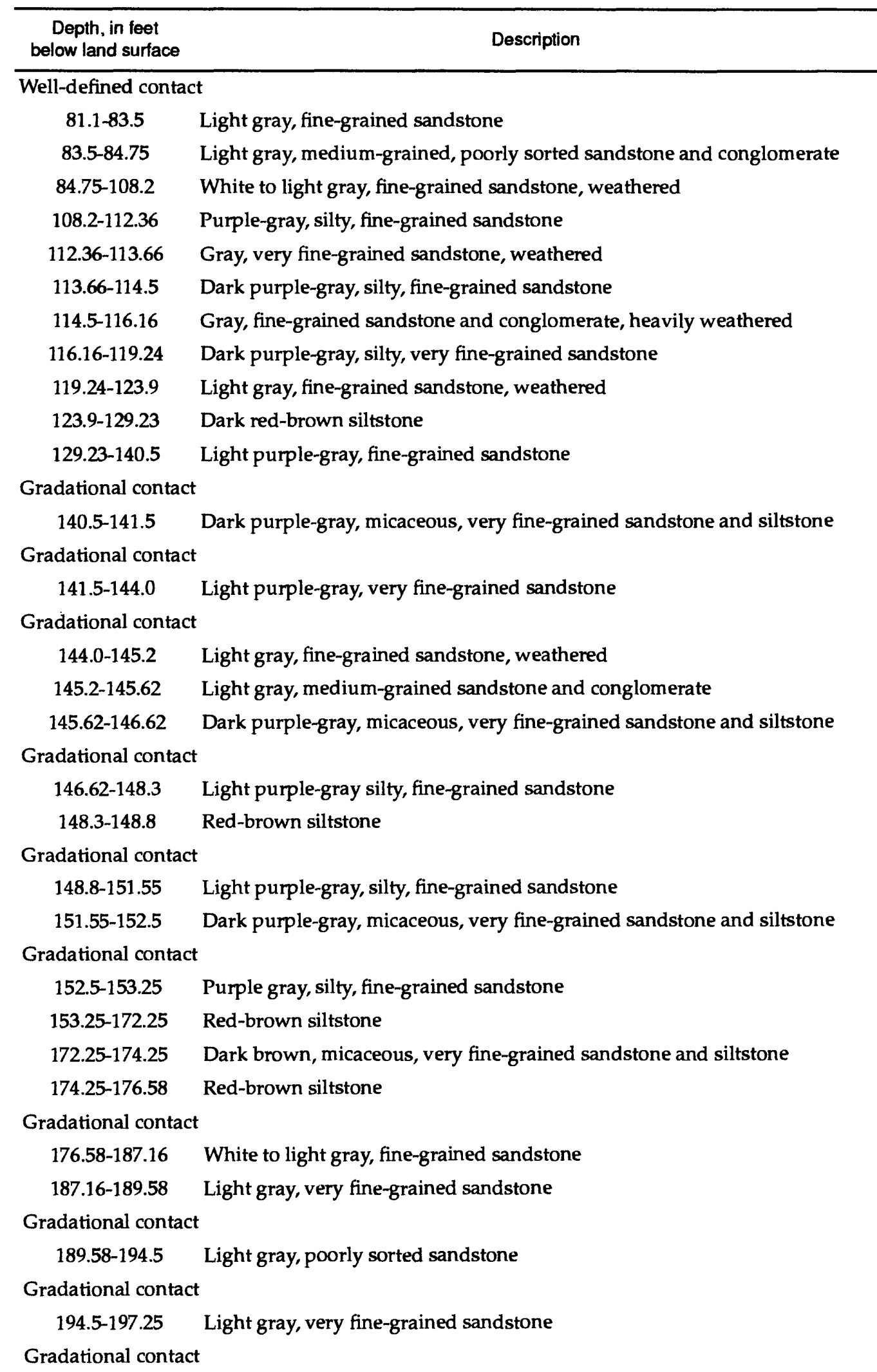


Table 3. Geologic log of rock core from corehole BK-2518, Fischer and Porter Site,

Warminster, Pa.-Continued

\begin{tabular}{|c|c|}
\hline $\begin{array}{c}\text { Depth, in feet } \\
\text { below land surface }\end{array}$ & Description \\
\hline 197.25-200.9 & White-gray, fine-grained sandstone with abundant clasts (conglomerate) \\
\hline \multicolumn{2}{|l|}{ Gradational contact } \\
\hline 200.9-201.32 & Conglomerate with thin, dark gray siltstone beds \\
\hline 201.32-209.0 & Light gray, fine-grained sandstone \\
\hline 209.0-211.5 & Light gray, coarse-grained conglomerate \\
\hline \multicolumn{2}{|c|}{ Gradational contact } \\
\hline 211.5-214.5 & Light gray, fine-grained sandstone \\
\hline \multicolumn{2}{|l|}{ Gradational contact } \\
\hline 214.5-217.25 & Light gray, medium-grained sandstone, weathered \\
\hline \multicolumn{2}{|l|}{ Gradational contact } \\
\hline 217.25-219.0 & Light gray, fine-grained sandstone \\
\hline 219.0-224.75 & Dark gray, very fine-grained sandstone \\
\hline \multicolumn{2}{|l|}{ Gradational contact } \\
\hline $224.75-225.25$ & Red-brown and gray conglomerate \\
\hline 225.25-226.95 & Dark purple-brown, silty, micaceous, fine-grained sandstone \\
\hline \multicolumn{2}{|c|}{ Gradational contact } \\
\hline 226.95-234.0 & Red-brown siltstone \\
\hline \multicolumn{2}{|c|}{ Gradational contact } \\
\hline 234.0-239.75 & Dark gray, very fine-grained sandstone \\
\hline 239.75-240.9 & Light gray, fine-grained sandstone \\
\hline 240.9-243.85 & Light gray, fine-grained sandstone \\
\hline 243.85-244.35 & Conglomerate \\
\hline $244.35-245.0$ & Light gray, fine-grained sandstone \\
\hline $245.0-245.66$ & Conglomerate with thin beds of red-brown siltstone \\
\hline $245.66-262.1$ & Light gray, fine-grained sandstone, weathered \\
\hline 262.1-262.52 & Dark gray, very fine-grained sandstone \\
\hline 262.52-265.6 & Light gray, fine-grained sandstone \\
\hline 265.6-265.9 & Red-brown siltstone \\
\hline 265.9-271.25 & Light gray, fine-grained sandstone \\
\hline 271.25-274.5 & Red-brown siltstone \\
\hline
\end{tabular}


Table 1. Geologic log for borehole BK-2511, Fischer and Porter Site, Warminister, Pa.

[gal/min, gallons per minute]

\begin{tabular}{cl}
\hline $\begin{array}{c}\text { Depth, in feet below } \\
\text { land surface }\end{array}$ & \\
\hline $0-50$ & Overburden \\
$50-55$ & Purple-gray siltstone \\
$55-62$ & Purple-gray, very fine-grained sandstone \\
$62-69$ & Red-brown siltstone \\
$69-75$ & Purple-gray siltstone \\
$75-90$ & Purple-gray, very fine-grained sandstone/siltstone \\
$90-96$ & Purple-gray siltstone \\
$96-100$ & Red-brown siltstone \\
$100-104$ & Purple-gray siltstone \\
$104-108$ & Light gray, medium-grained sandstone \\
$108-121$ & Red-brown siltstone with interbedded green siltstone/shale \\
$121-135$ & Purple-gray, very fine-grained sandstone with interbeded green \\
& siltstone/shale \\
$135-142$ & Light gray, medium-grained sandstone \\
$142-148$ & Purple-gray, fine-grained sandstone \\
$148-168$ & Purple-gray siltstone \\
$168-173$ & Purple-gray, very fine-grained sandstone; 5 gal/min at 170 \\
$173-178$ & Purple-gray, fine-grained sandstone \\
$178-228$ & Light gray, fine-grained sandstone with interbedded green siltstone/shale \\
$228-237$ & Red-brown siltstone \\
$237-242$ & Red-brown, very fine-grained silty sandstone \\
$242-249$ & Dark-gray siltstone \\
$249-264$ & Red-brown siltstone \\
$264-270$ & Light gray, very fine-grained sandstone; 5 gal/min at 270 \\
$270-289$ & Light gray, fine-grained sandstone \\
$289-305$ & Red-brown siltstone \\
$305-316$ & Light purple-gray, very fine-grained sandstone; 5 gal/min at 315 \\
$316-321$ & Red-gray siltstone \\
$321-332$ & Light gray, fine-grained sandstone \\
$332-349$ & Light gray, very fine-grained sandstone \\
$349-352$ & Red-brown siltstone \\
\hline &
\end{tabular}


Table 2. Geologic log for borehole BK-2512, Fischer and Porter Site, Warminster, Pa.

[gal/min, gallons per minute; >, greater than]

\begin{tabular}{cl}
\hline $\begin{array}{c}\text { Depth, in feet below } \\
\text { land surface }\end{array}$ & \multicolumn{1}{c}{ Description } \\
\hline $0-20$ & Overburden \\
$20-30$ & Light gray, fine-grained sandstone \\
$30-51$ & Red-brown siltstone \\
$51-76$ & Dark brown siltstone; 10 gal/min at 54 \\
$76-106$ & Light gray, fine-grained sandstone; 8 gal $/$ min at $98 ; 7$ gal $/ \mathrm{min}$ at 106 \\
$106-111$ & Purple-gray, silty, very fine-grained sandstone \\
$111-126$ & Transition zone with interbedded red-brown siltstone \\
$126-131$ & Light gray, fine-grained sandstone \\
$131-152$ & Purple-gray, silty, very fine-grained sandstone; 20 gal $/ \mathrm{min}$ at 146 \\
$152-168$ & Red-brown siltstone \\
$168-204$ & Light gray, fine-grained sandstone with interbedded dark gray, silty, very \\
& fine-grained sandstone; 5 gal/min at $178 ; 20$ gal $/ \mathrm{min}$ at 189 \\
$204-214$ & White-gray, medium-grained sandstone \\
$214-235$ & Dark purple-gray, silty, very fine-grained sandstone; 20 gal/min at 230 \\
$235-263$ & Light gray, fine-grained sandstone; $>20$ gal/min at $245 ;>50$ gal/min at 250 \\
$263-271$ & Red-brown siltstone \\
$271-276$ & Light gray, fine-grained sandstone \\
$276-281$ & Purple-gray siltstone \\
$281-286$ & Light gray, fine-grained sandstone \\
$286-302$ & Purple-gray siltstone \\
$302-303$ & Red-brown siltstone \\
\hline
\end{tabular}


Table 3. Geologic log for borehole BK-2513, Fischer and Porter Site, Warminster, Pa.

[gal/min; gallons per minute]

\begin{tabular}{cl}
\hline $\begin{array}{c}\text { Depth, in feet below } \\
\text { land surface }\end{array}$ & \\
\hline $0-35$ & Overburden \\
$35-50$ & Red-brown siltstone \\
$50-61$ & Purple-brown, silty, very fine-grained sandstone; 5 gal/min at 60 \\
$61-86$ & Light purple-gray, very fine-grained sandstone \\
$86-96$ & Dark red-brown siltstone \\
$96-102$ & Purple-gray, very fine-grained, silty sandstone \\
$102-112$ & Dark purple-gray siltstone \\
$112-138$ & Gray, very fine-grained sandstone; 15 gal/min at 120; 60 gal/min at 131 \\
$138-149$ & White-gray, medium-grained sandstone \\
$149-158$ & White-gray, fine-grained sandstone \\
$158-165$ & Dark gray siltstone; 20 gal/min at 160 \\
$165-185$ & Light gray, fine-grained sandstone; 20 gal/min at 171 \\
$185-190$ & Dark gray, very fine-grained sandstone \\
$190-220$ & Light gray, very fine-grained to fine-grained sandstone \\
$220-225$ & Dark gray, siltstone/silty sandstone \\
$225-245$ & Red-brown siltstone \\
$245-251$ & Gray, very fine-grained sandstone \\
$251-256$ & Red-brown siltstone \\
$256-261$ & Dark gray, very fine-grained to fine-grained sandstone \\
$261-276$ & Light gray, fine-grained sandstone \\
$276-281$ & White-gray, medium-grained sandstone \\
$281-300$ & Red-brown siltstone \\
\hline &
\end{tabular}


Table 4. Geologic log for borehole BK-2514, Fischer and Porter Site, Warminster, Pa.

[gal/min; gallons per minute]

\begin{tabular}{cl}
\hline $\begin{array}{c}\text { Depth, in feet below } \\
\text { land surface }\end{array}$ & \\
\hline $0-22$ & Overburden \\
$22-36$ & Red-brown siltstone, weathered \\
$36-70$ & Light-gray, very fine-grained to fine-grained sandstone \\
$70-75$ & Dark gray, fine-grained sandstone \\
$75-86$ & Light gray, fine-grained sandstone \\
$86-101$ & Red-brown siltstone \\
$101-112$ & Gray, very fine-grained sandstone \\
$112-138$ & Red-brown siltstone \\
$138-159$ & Gray, very fine-grained to fine-grained sandstone \\
$159-180$ & Red-brown siltstone \\
$180-191$ & Purple-gray, very fine-grained sandstone \\
$191-226$ & White-gray, fine-grained sandstone; 5 gal/min at $200 ; 5$ gal/min at 215 \\
$226-258$ & Dark purple-gray, very fine-grained sandstone/silty sandstone \\
$258-263$ & Red-brown siltstone \\
$263-267$ & Dark gray, silty, fine-grained sandstone and siltstone; 5 gal/min \\
$267-292$ & Light gray, very fine-grained sandstone \\
\hline
\end{tabular}


Table 5. Geologic log for borehole BK-2515, Fischer and Porter Site, Warminster, Pa.

[gal/min; gallons per minute]

\begin{tabular}{cl}
\hline $\begin{array}{c}\text { Depth, in feet below } \\
\text { land surface }\end{array}$ & \\
\hline $0-25$ & Overburden \\
$25-30$ & Dark gray, silty fine-grained sandstone \\
$30-40$ & Dark-gray, very fine-grained sandstone; 20 gal/min at 31 \\
$40-46$ & Red-brown siltstone \\
$46-57$ & Dark gray, silty, fine-grained sandstone \\
$57-66$ & Dark gray, very fine-grained sandstone \\
$66-82$ & Red-brown siltstone \\
$82-87$ & Purple-gray, silty, fine-grained sandstone \\
$87-97$ & Red-brown siltstone \\
$97-102$ & Dark gray, silty, fine-grained sandstone \\
$102-112$ & Light gray, very fine-grained to fine-grained sandstone \\
$112-124$ & Dark gray siltstone \\
$124-132$ & Dark gray silty, fine-grained sandstone \\
$132-148$ & Red-brown siltstone \\
$148-158$ & Dark gray siltstone \\
$158-193$ & Light gray, very fine-grained to fine-grained sandstone \\
$193-209$ & Red-brown siltstone; 3 gal/min at 208 \\
$209-225$ & Red-brown siltstone to silty, fine-grained sandstone \\
$225-232$ & Purple-gray, silty, fine-grained sandstone \\
$232-240$ & Red-brown siltstone \\
$240-245$ & Purple-gray, silty, fine-grained sandstone \\
$245-267$ & Light gray, very fine-grained to fine-grained sandstone \\
$267-282$ & Red-brown siltstone \\
$282-307$ & Light gray, very fine-grained to fine-grained sandstone with \\
& interbedded dark gray, silty, fine-grained sandstone; 3 gal/min at 282-287; \\
$307-313$ & Purple-gray, silty, fine-grained sandstone \\
\hline & \\
& \\
&
\end{tabular}




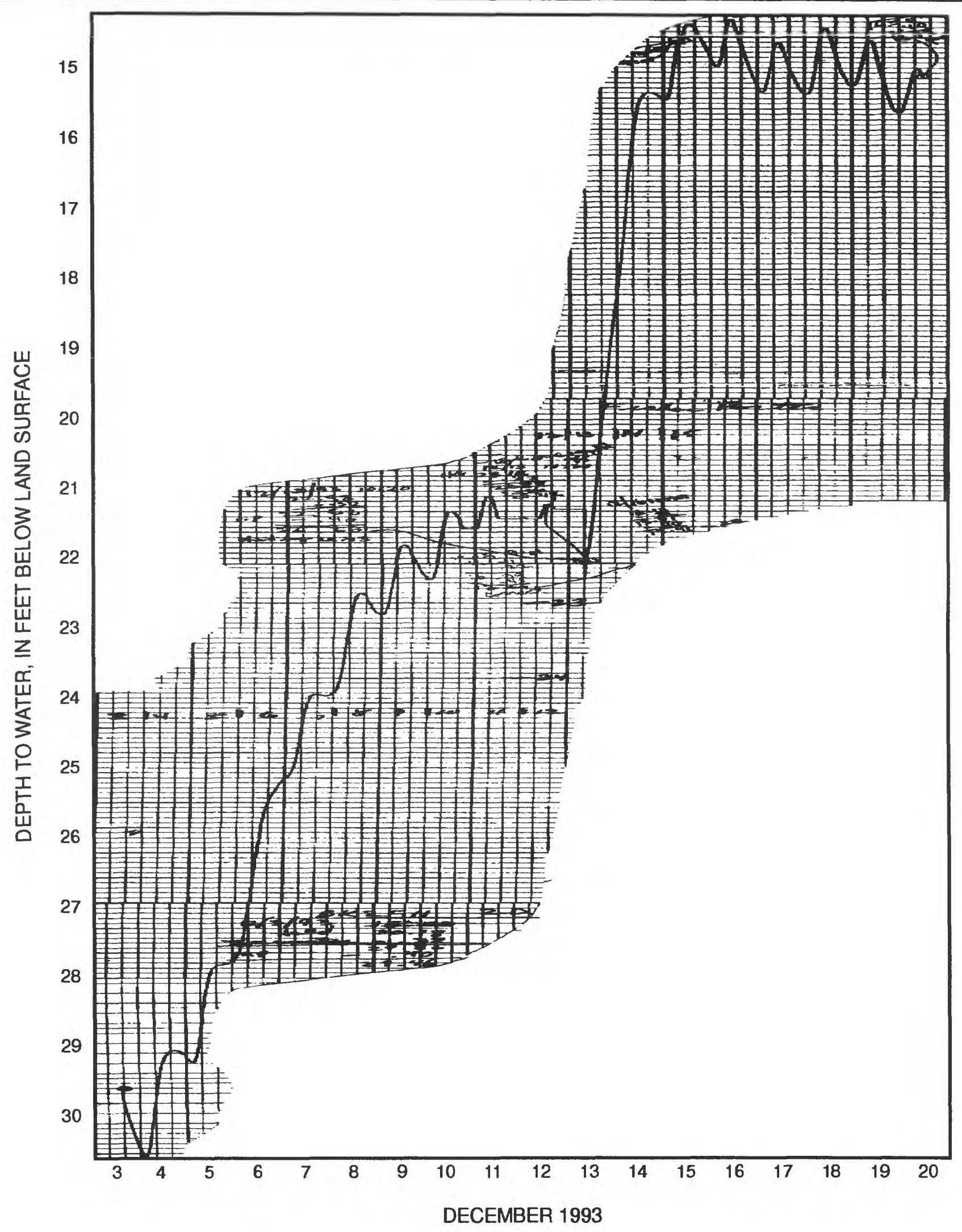

Figure 1. Hydrograph of well BK-2511, Fischer and Porter Site, Warminster, Pa., December 3-20, 1993. 


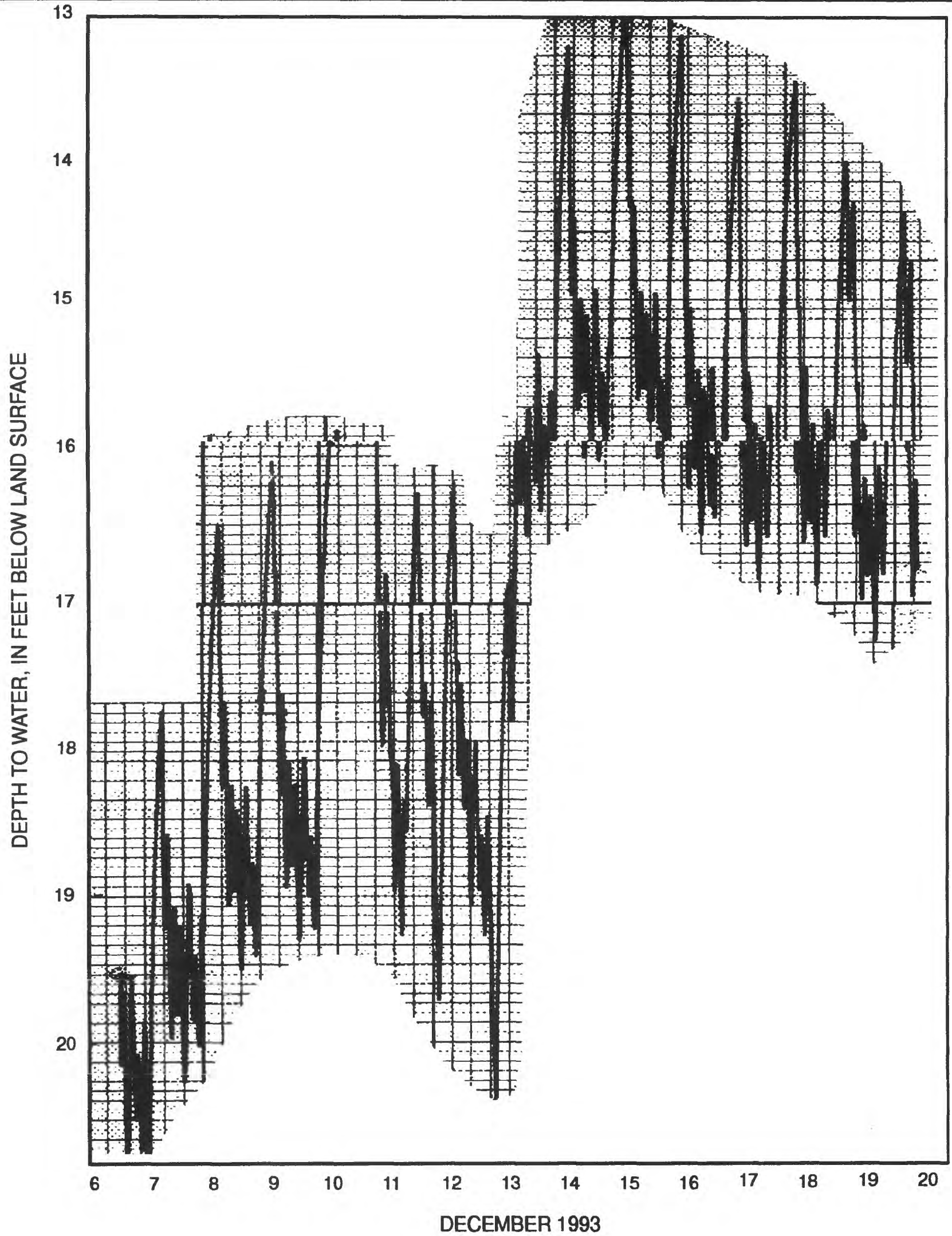

Figure 2. Hydrograph of well BK-2521, Fischer and Porter Site, Warminster, Pa., December 6-20, 1993. 


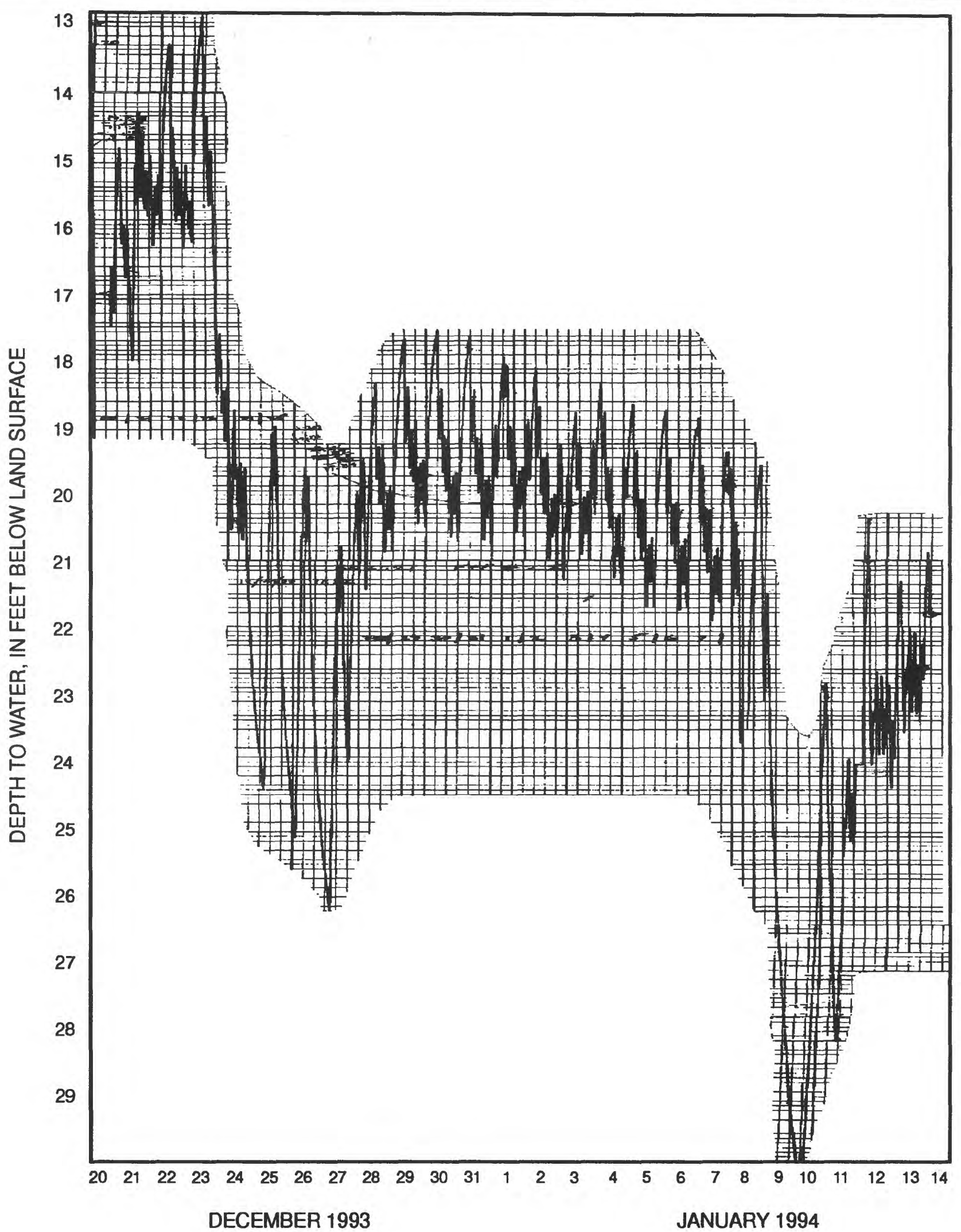

Figure 3. Hydrograph of well BK-2521, Fischer and Porter Site, Warminster, Pa., December 20, 1993, to January 14, 1994. 


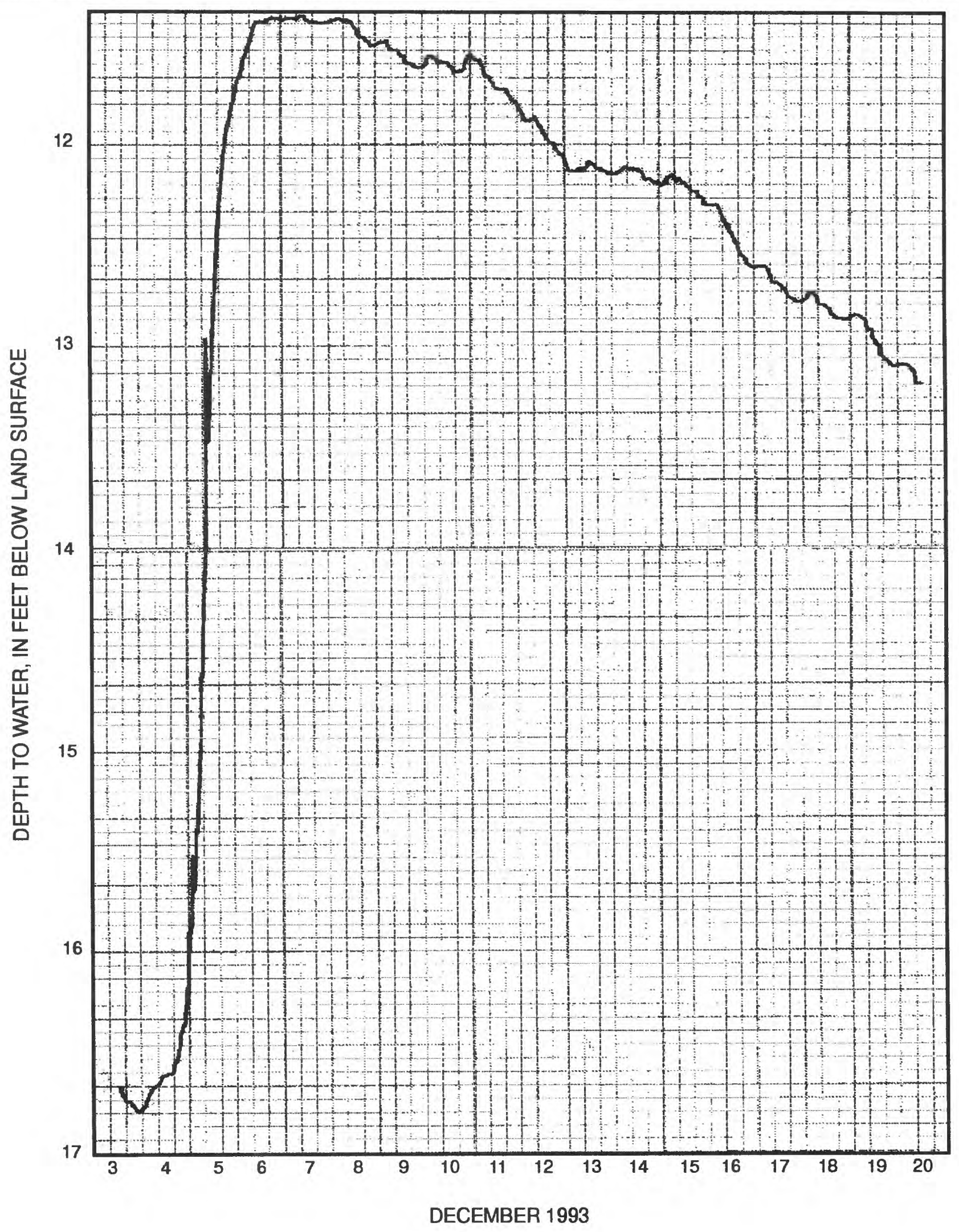

Figure 4. Hydrograph of well BK-1731, Fischer and Porter Site, Warminster, Pa., December 3-20, 1993. 


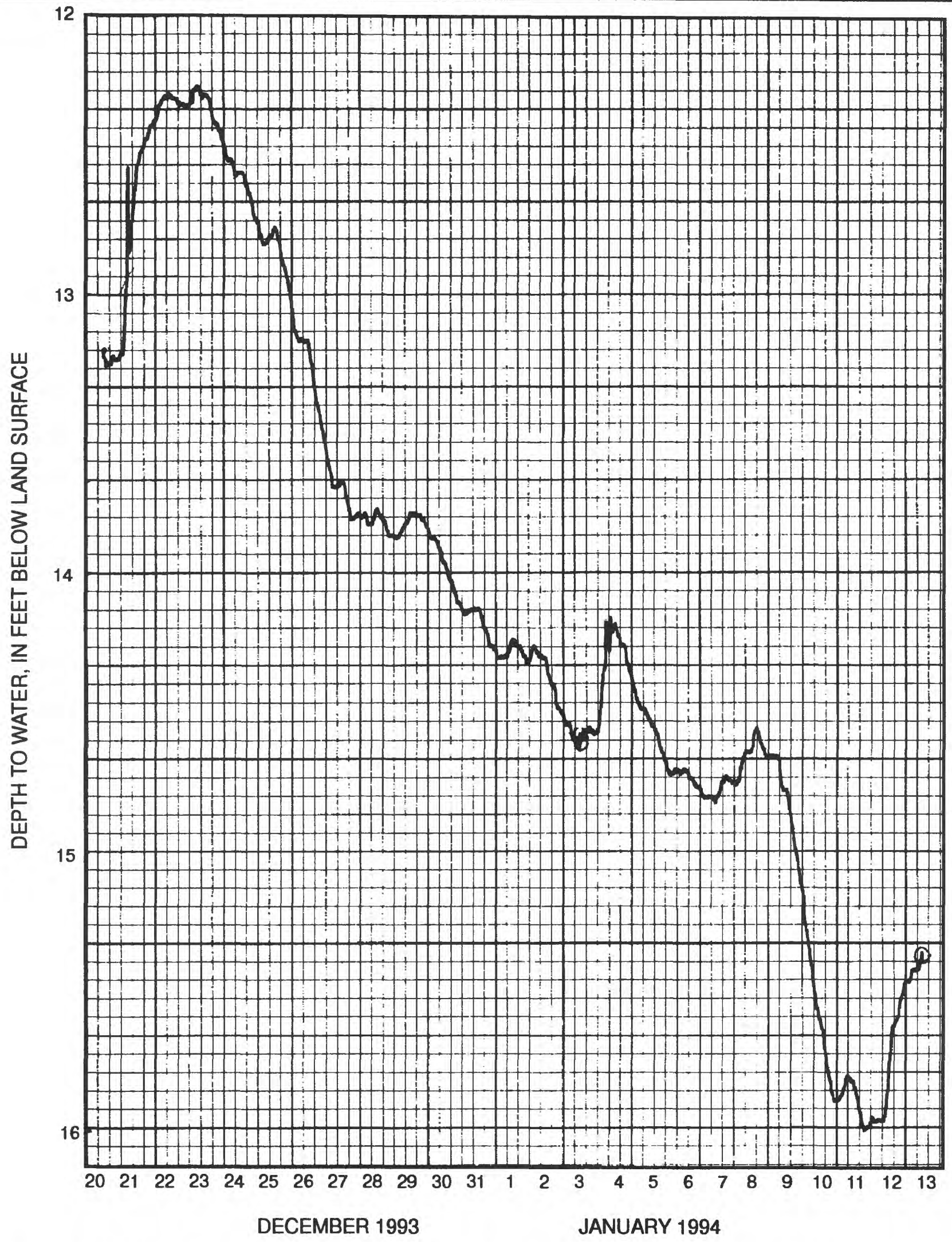

Figure 5. Hydrograph of well BK-1731, Fischer and Porter Site, Warminster, Pa., December 20, 1993, to January 13, 1994. 


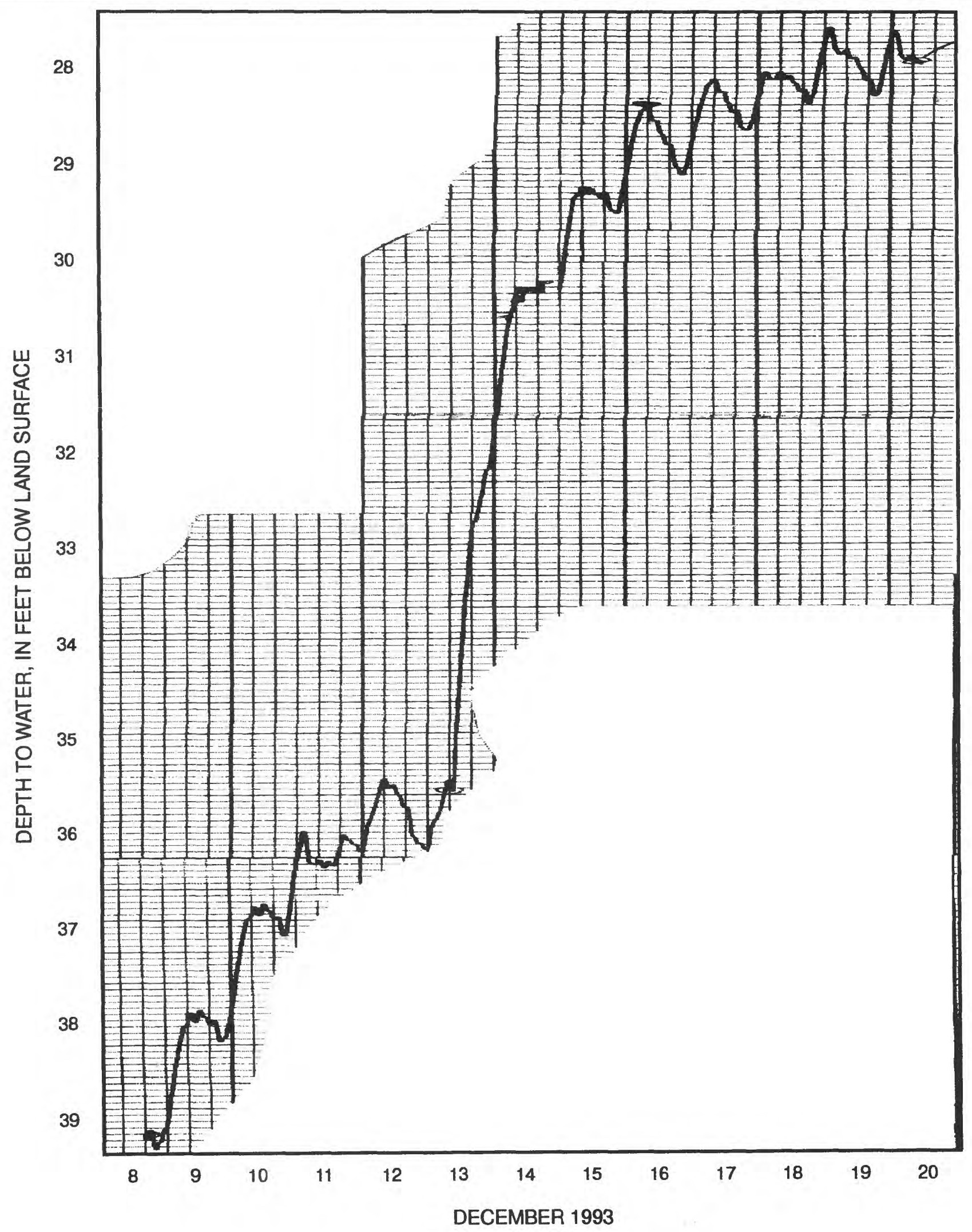

Figure 6. Hydrograph of well BK-2515, Fischer and Porter Site, Warminster, Pa., December 8-20, 1993. 


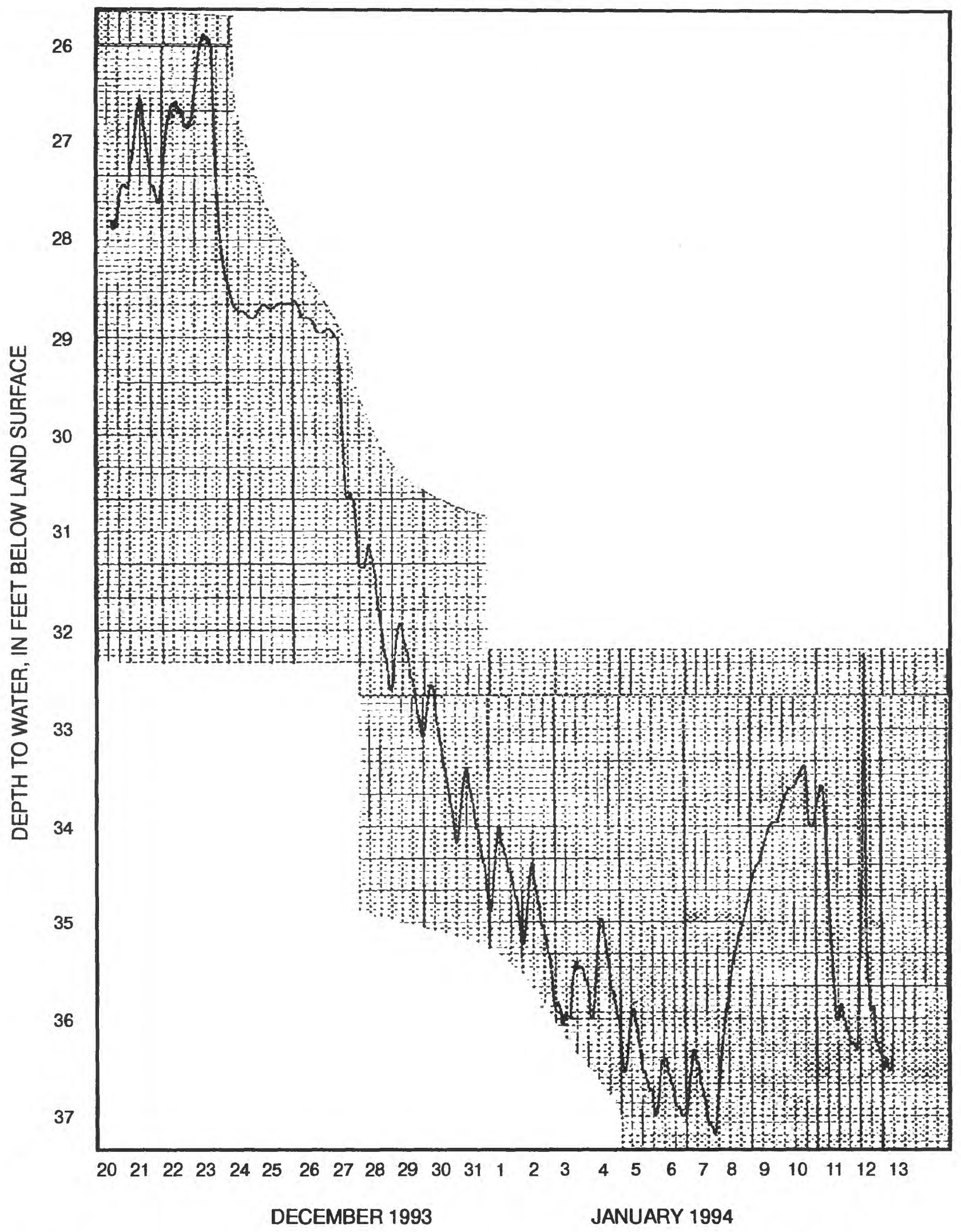

Figure 7. Hydrograph of well BK-2515, Fischer and Porter Site, Warminster, Pa., December 20, 1993, to January 13, 1994. 


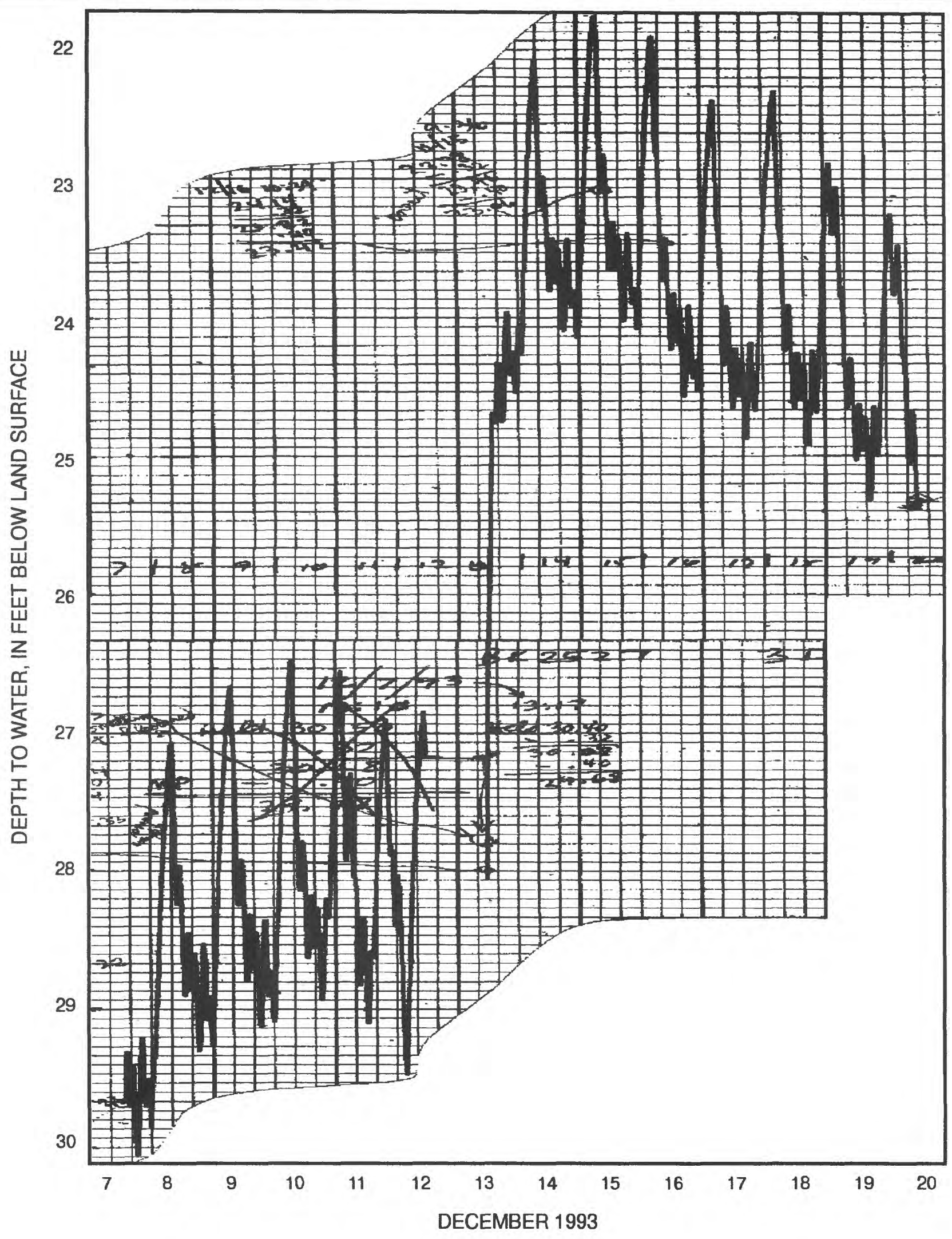

Figure 8. Hydrograph of well BK-2527, Fischer and Porter Site, Warminster, Pa., December 7-20, 1993. 


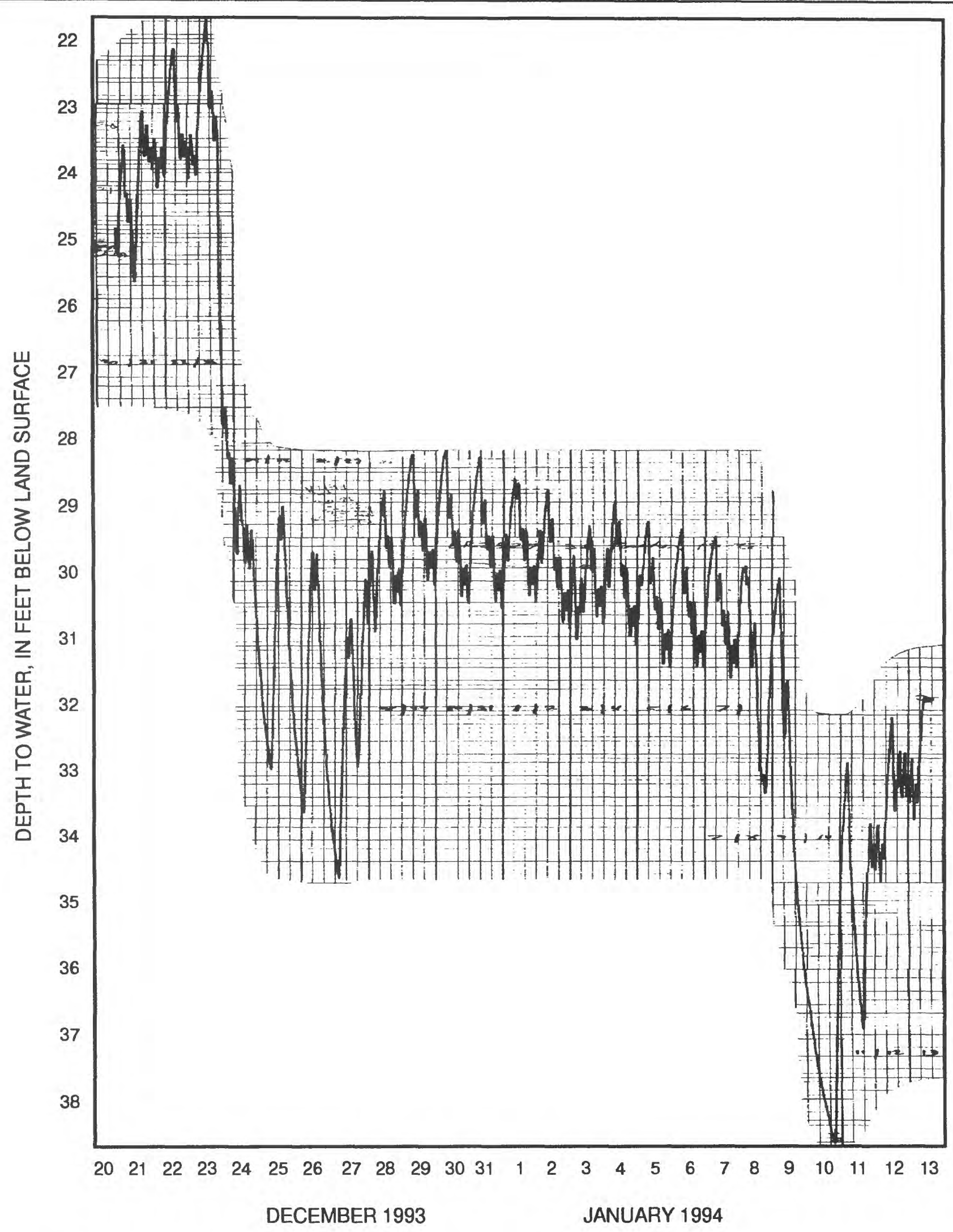

Figure 9. Hydrograph of well BK-2527, Fischer and Porter Site, Warminster, Pa., December 20, 1993, to January $13,1994$. 


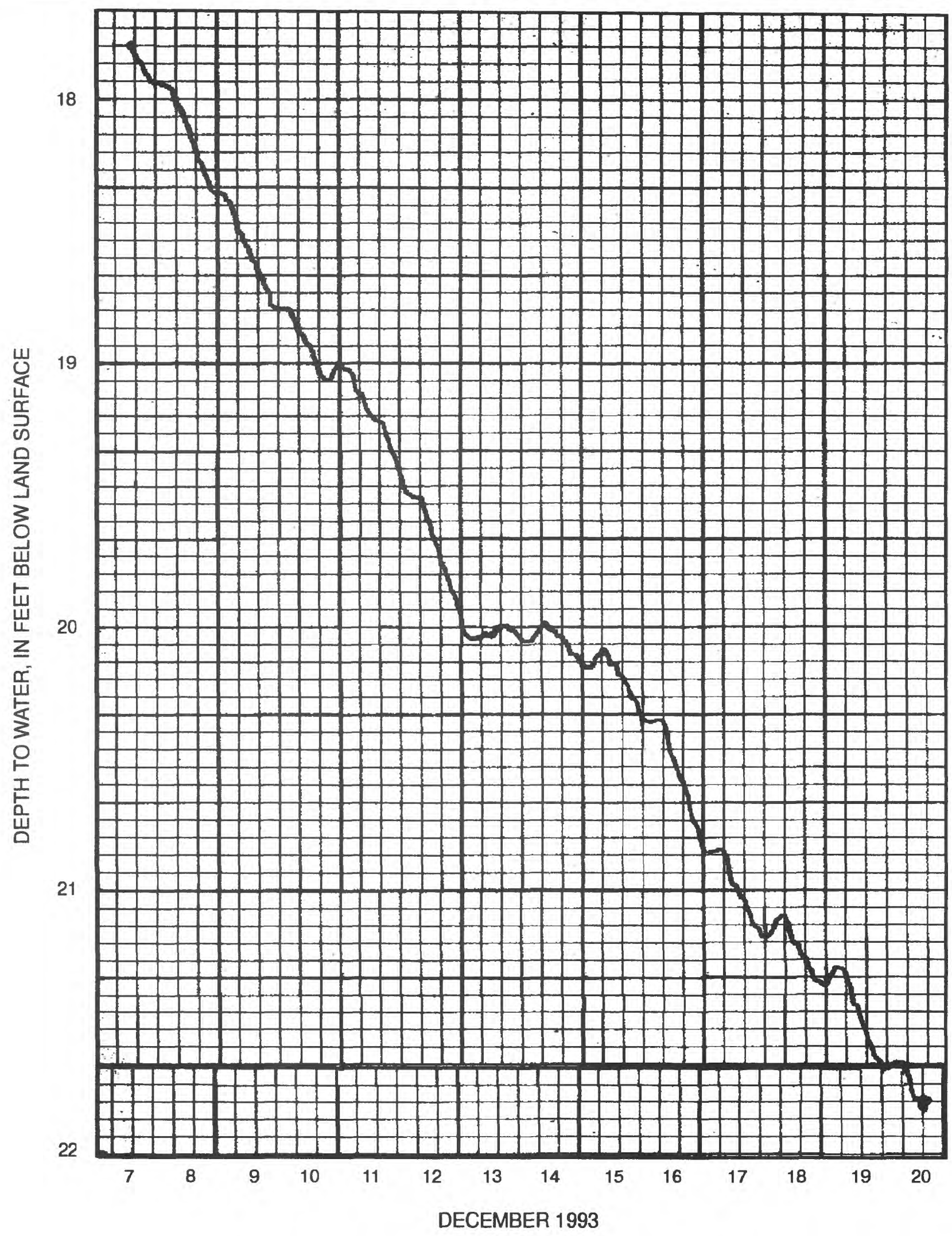

Figure 10. Hydrograph of well BK-2528, Fischer and Porter Site, Warminster, Pa., December 7- 20, 1993. 


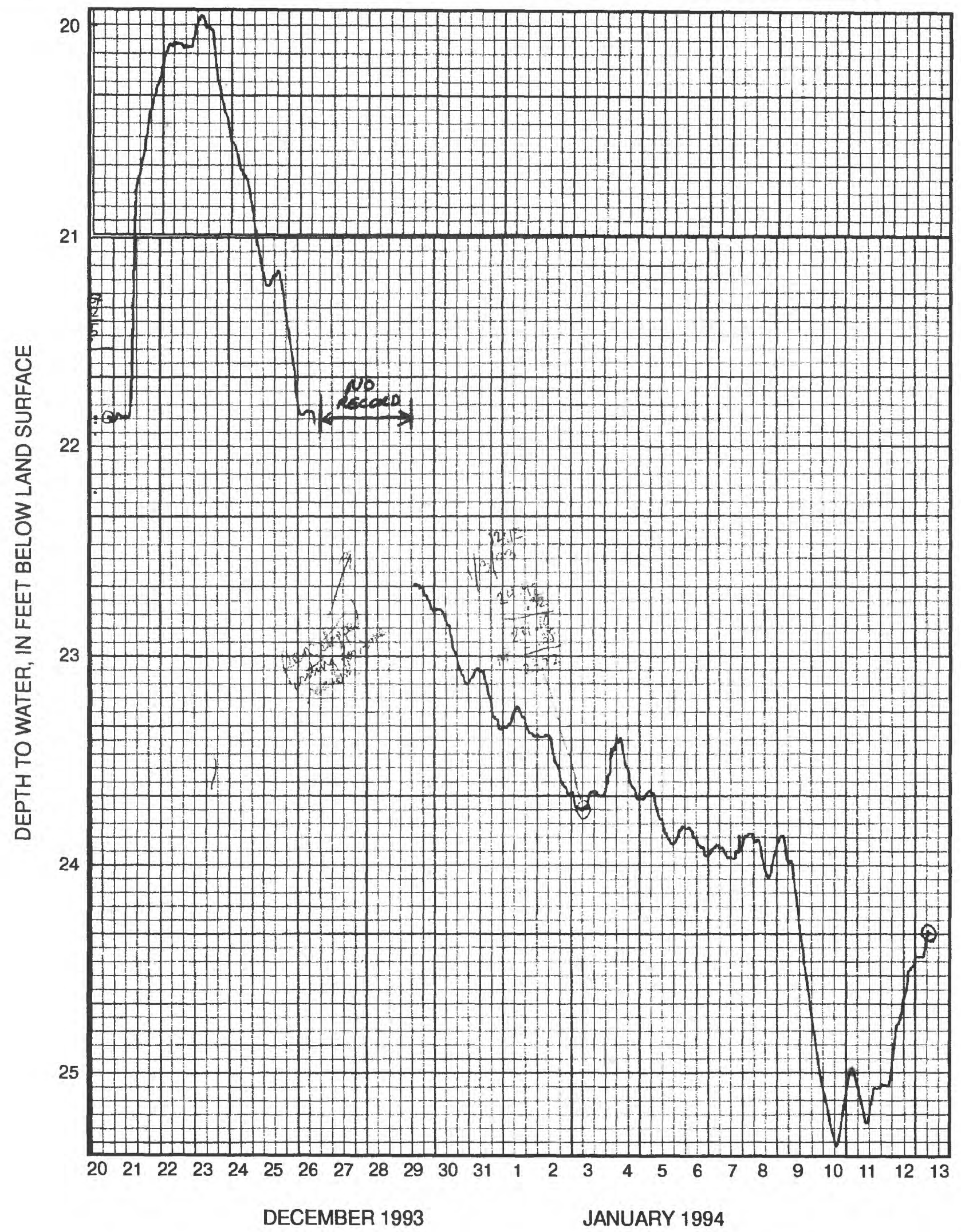

Figure 11. Hydrograph of well BK-2528, Fischer and Porter Site, Warminster, Pa., December 20, 1993, to January 13, 1994. 


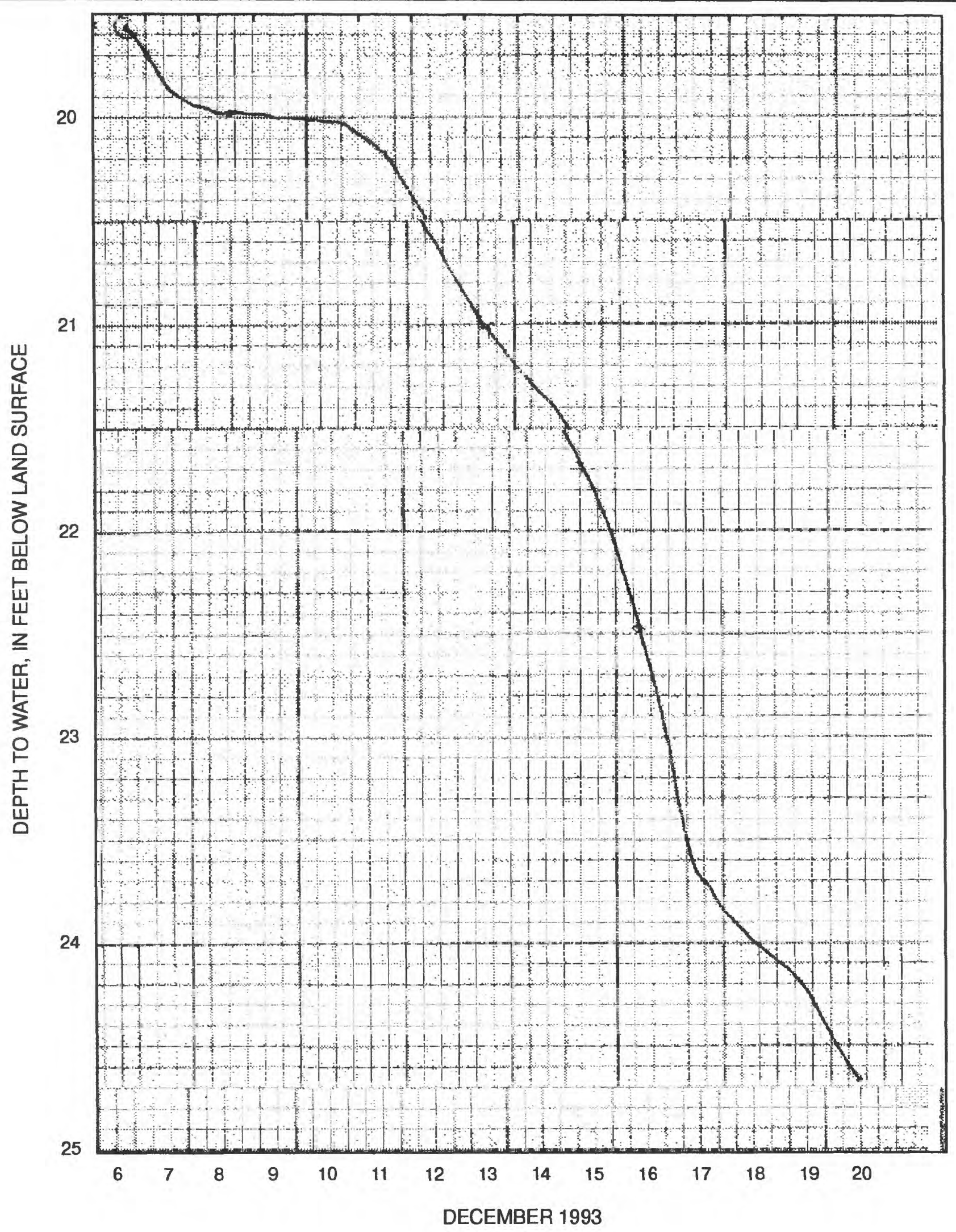

Figure 12. Hydrograph of well BK-1795, Fischer and Porter Site, Warminster, Pa., December 6-20, 1993. 


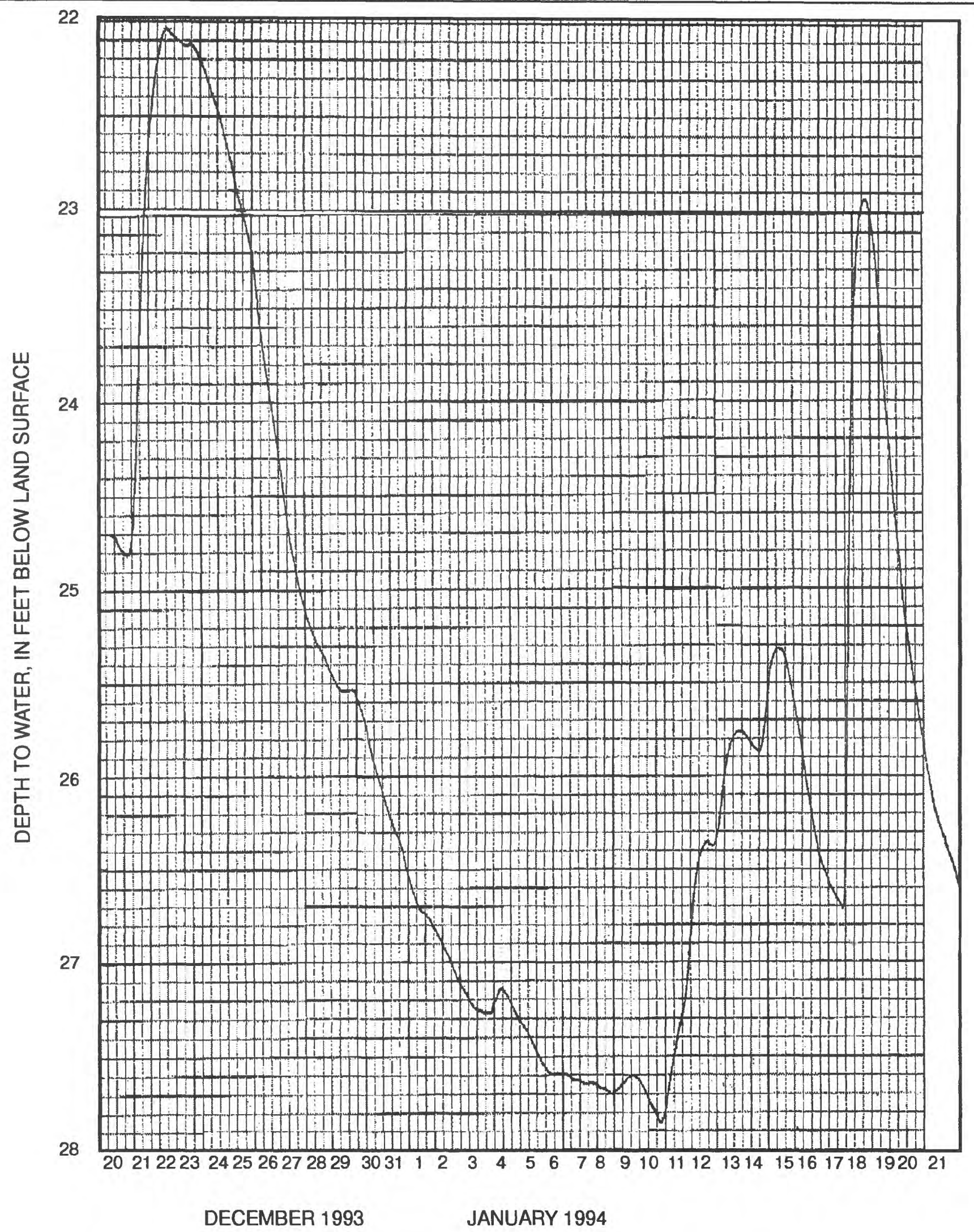

Figure 13. Hydrograph of well BK-1795, Fischer and Porter Site, Warminster, Pa., December 20, 1993, to January 21, 1994. 


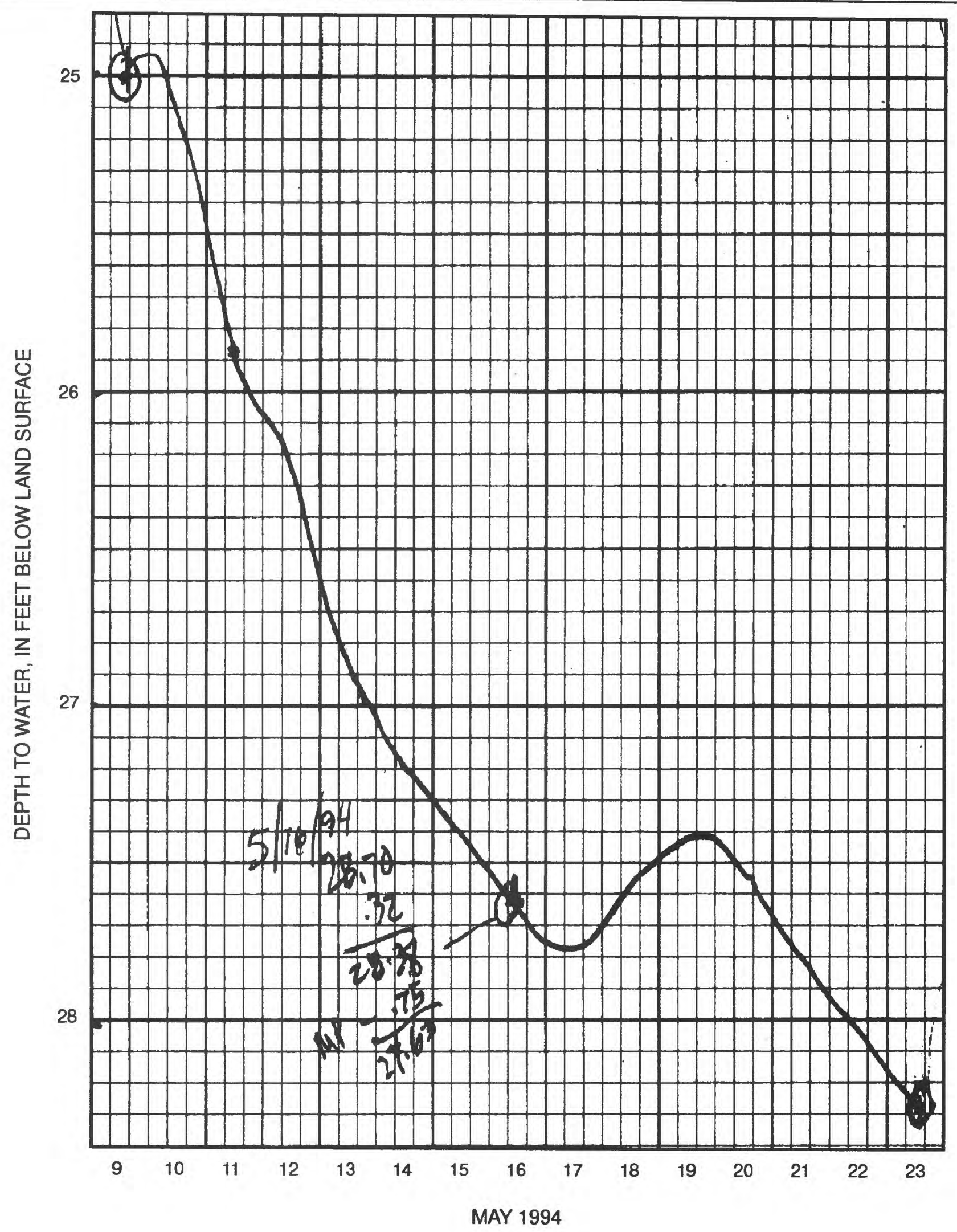

Figure 14. Hydrograph of well BK-1795, Fischer and Porter Site, Warminster, Pa., May 9-23, 1994. 


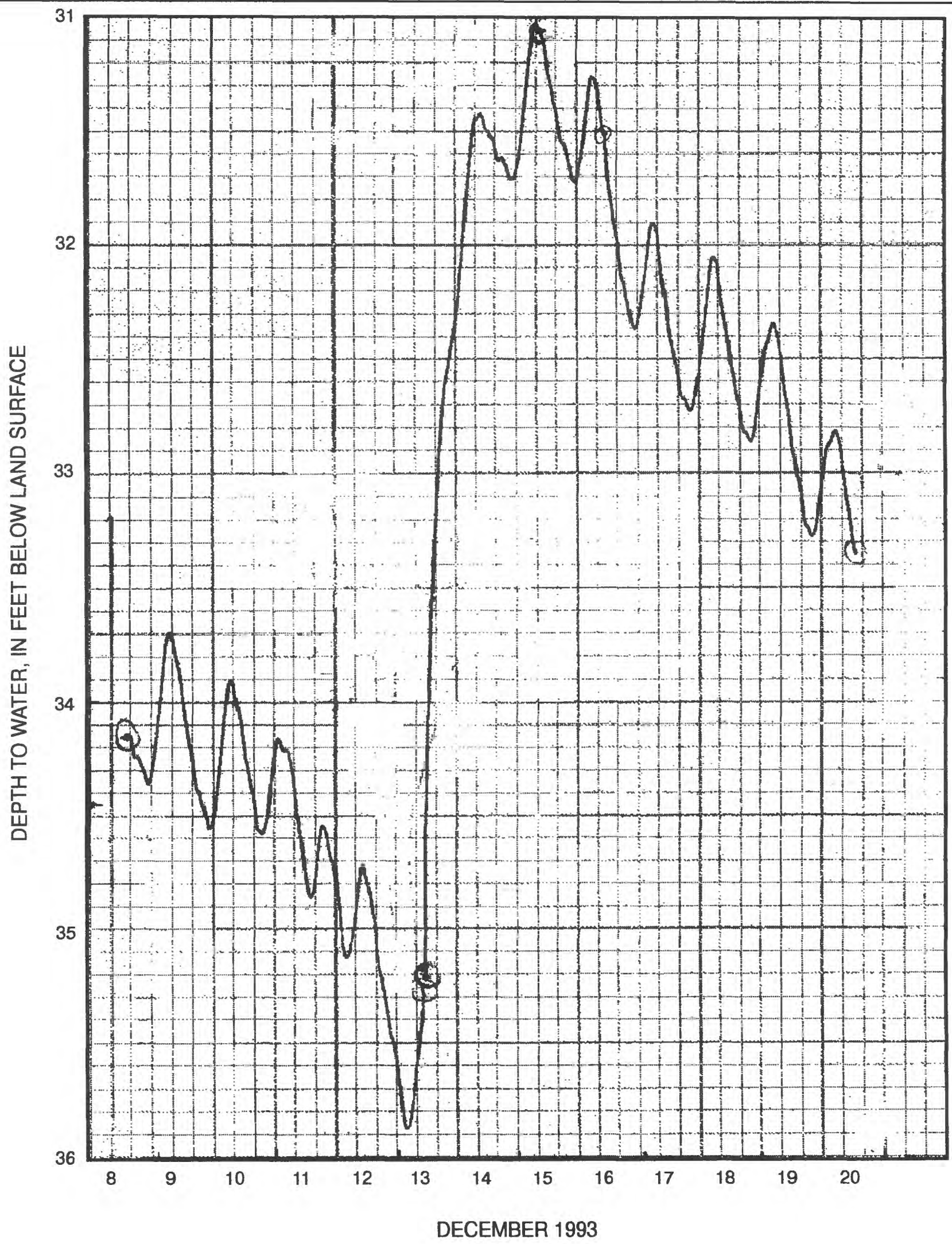

Figure 15. Hydrograph of well BK-1796, Fischer and Porter Site, Warminster, Pa., December 8- 20, 1993. 


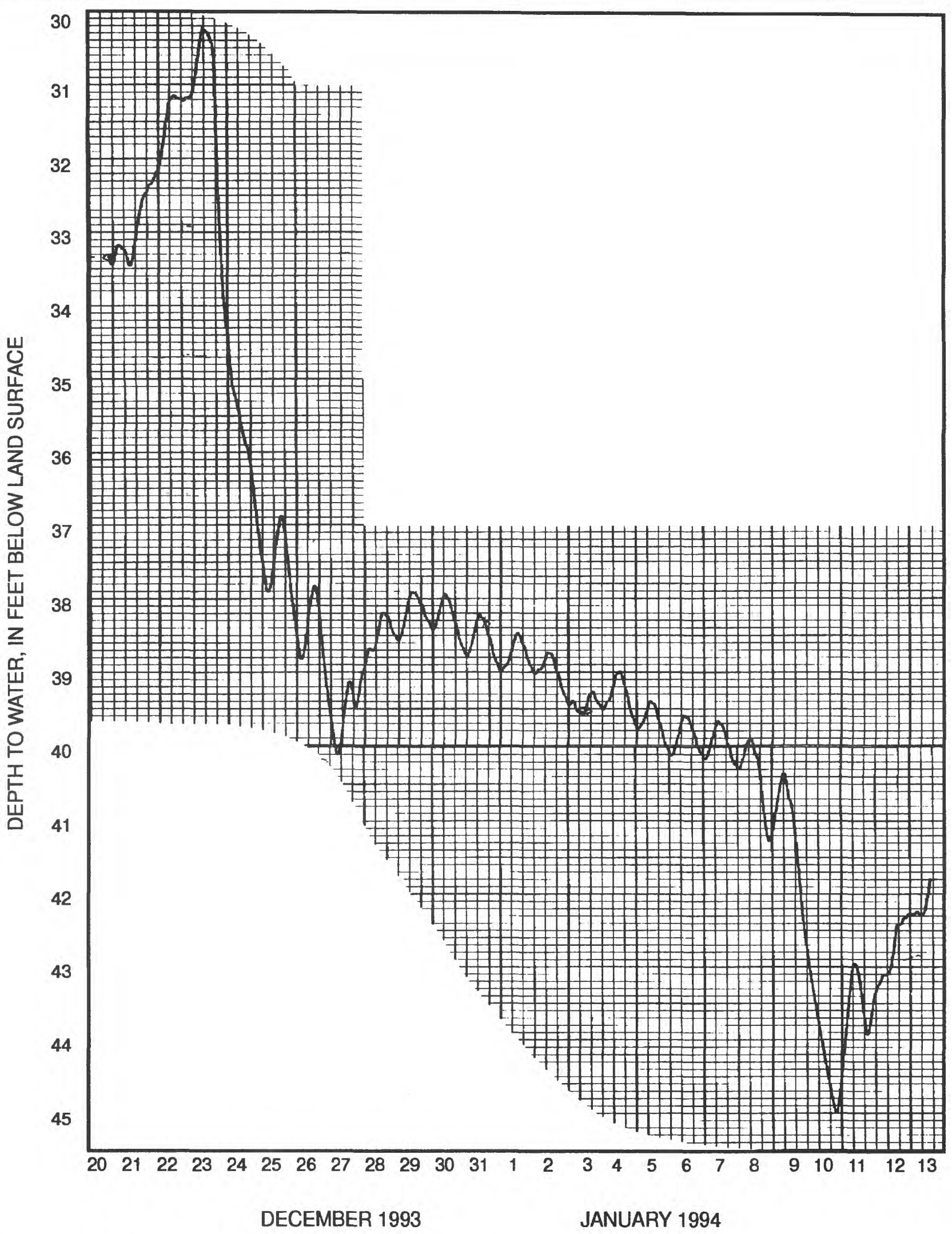

Figure 16. Hydrograph of well BK-1796, Fischer and Porter Site, Warminster, Pa., December 20, 1993, to January 13, 1994. 


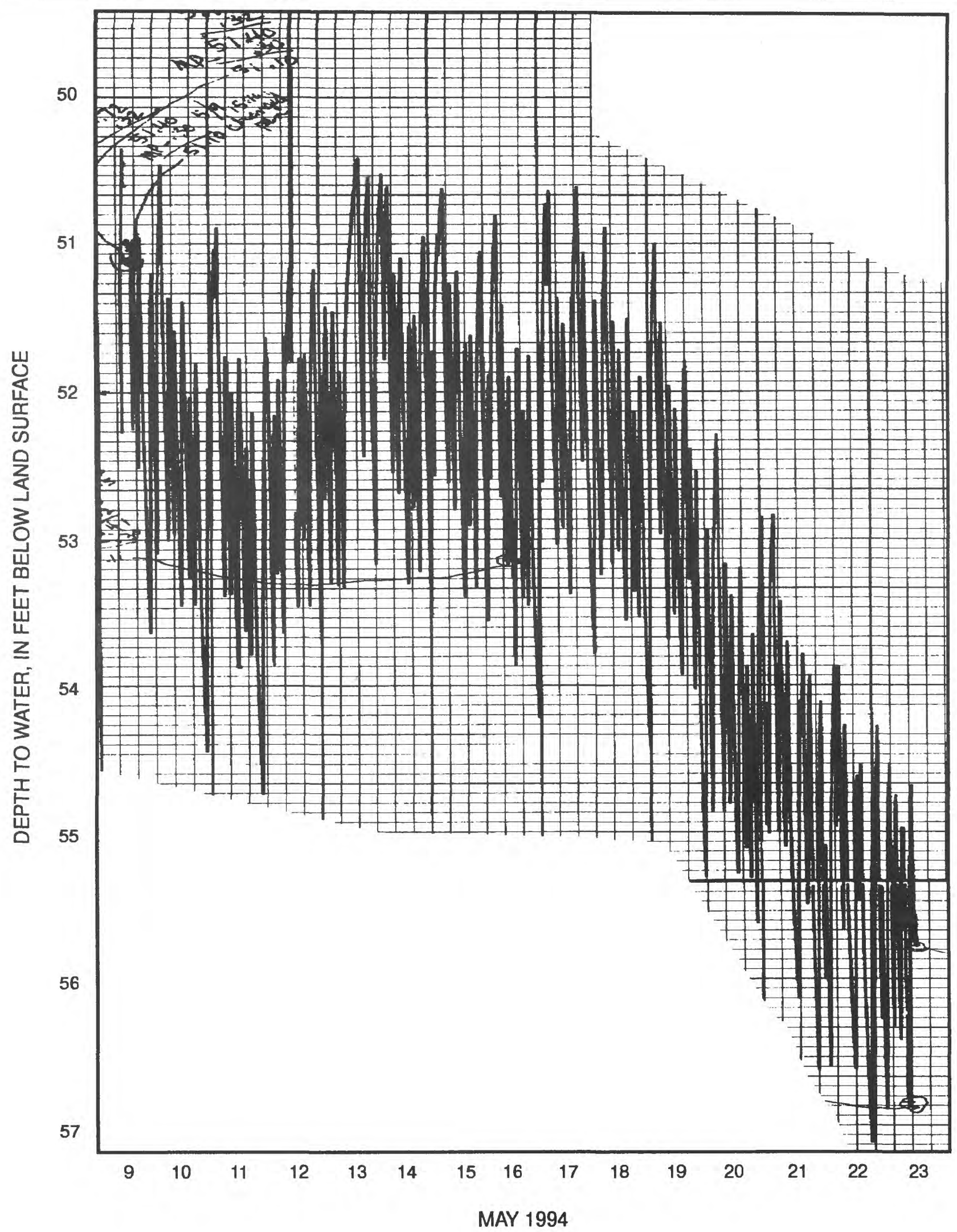

Figure 17. Hydrograph of well BK-2514, Fischer and Porter Site, Warminster, Pa., May 9-23, 1994. 


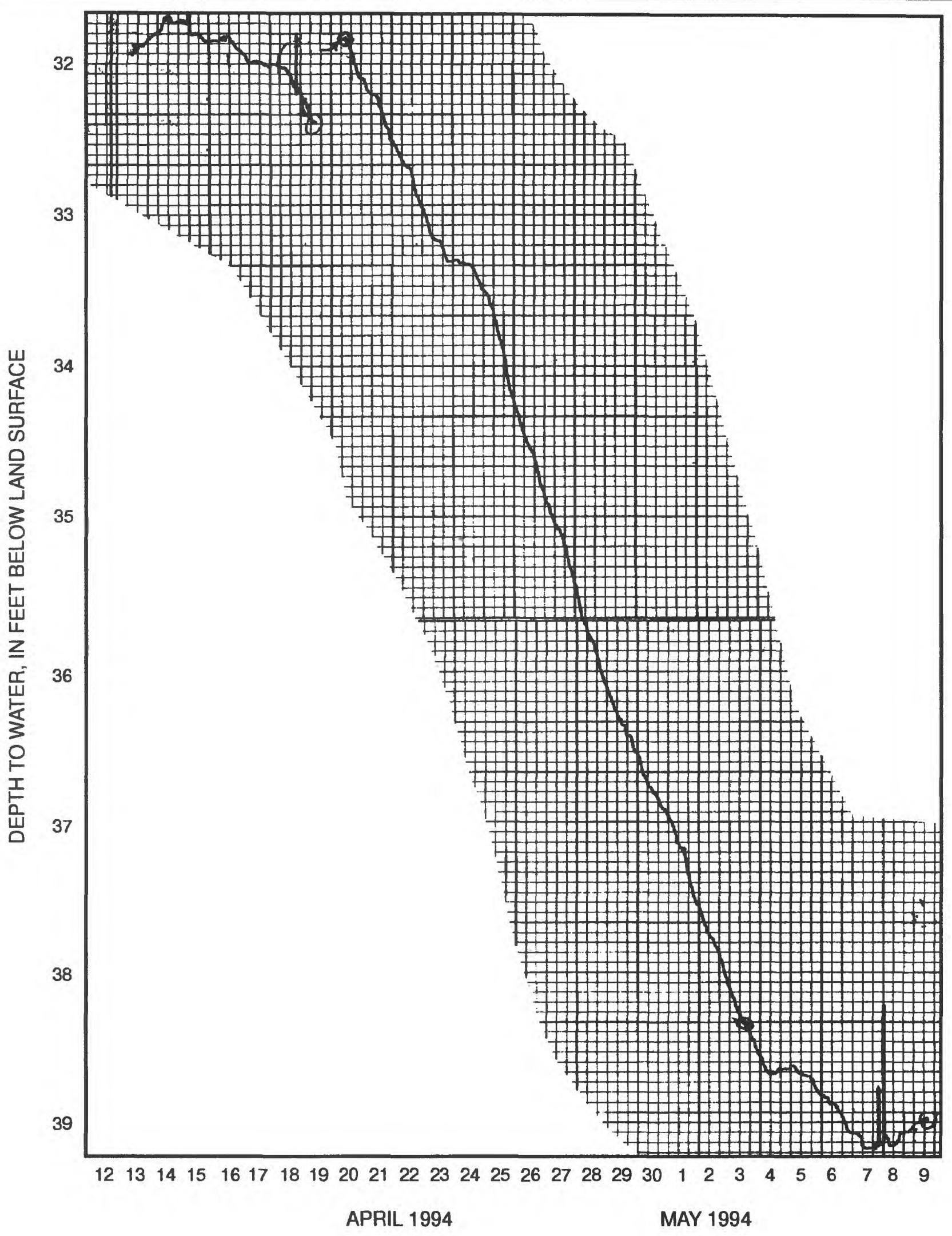

Flgure 18. Hydrograph of well BK-2526, Fischer and Porter Site, Warminster, Pa., April 12 to May 9, 1994. 


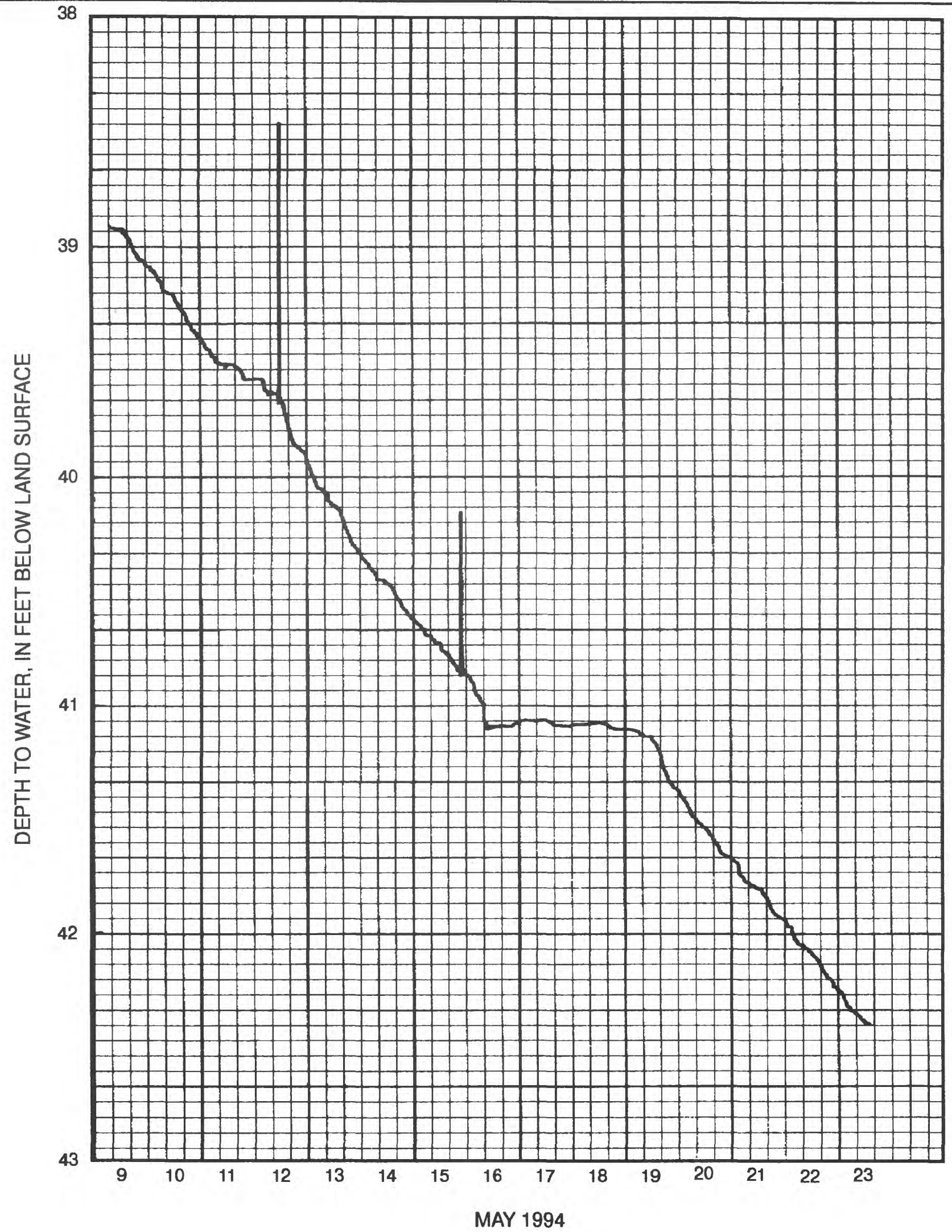

Flgure 19. Hydrograph of well BK-2526, Fischer and Porter Site, Warminster, Pa., May 9-23, 1994 


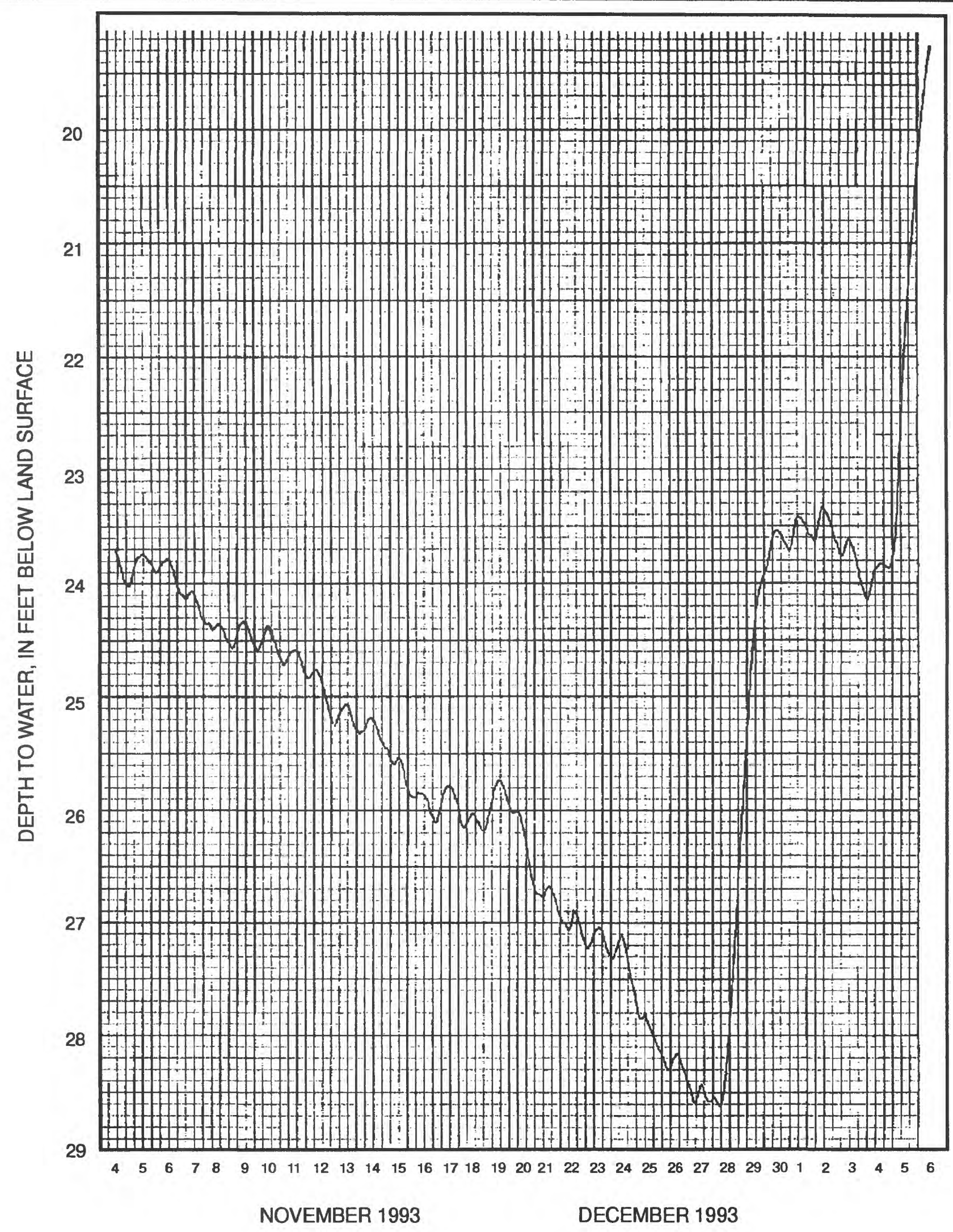

Flgure 20. Hydrograph of well BK-1793, Fischer and Porter Site, Warminster, Pa., November 4 to December 6, 1993. 


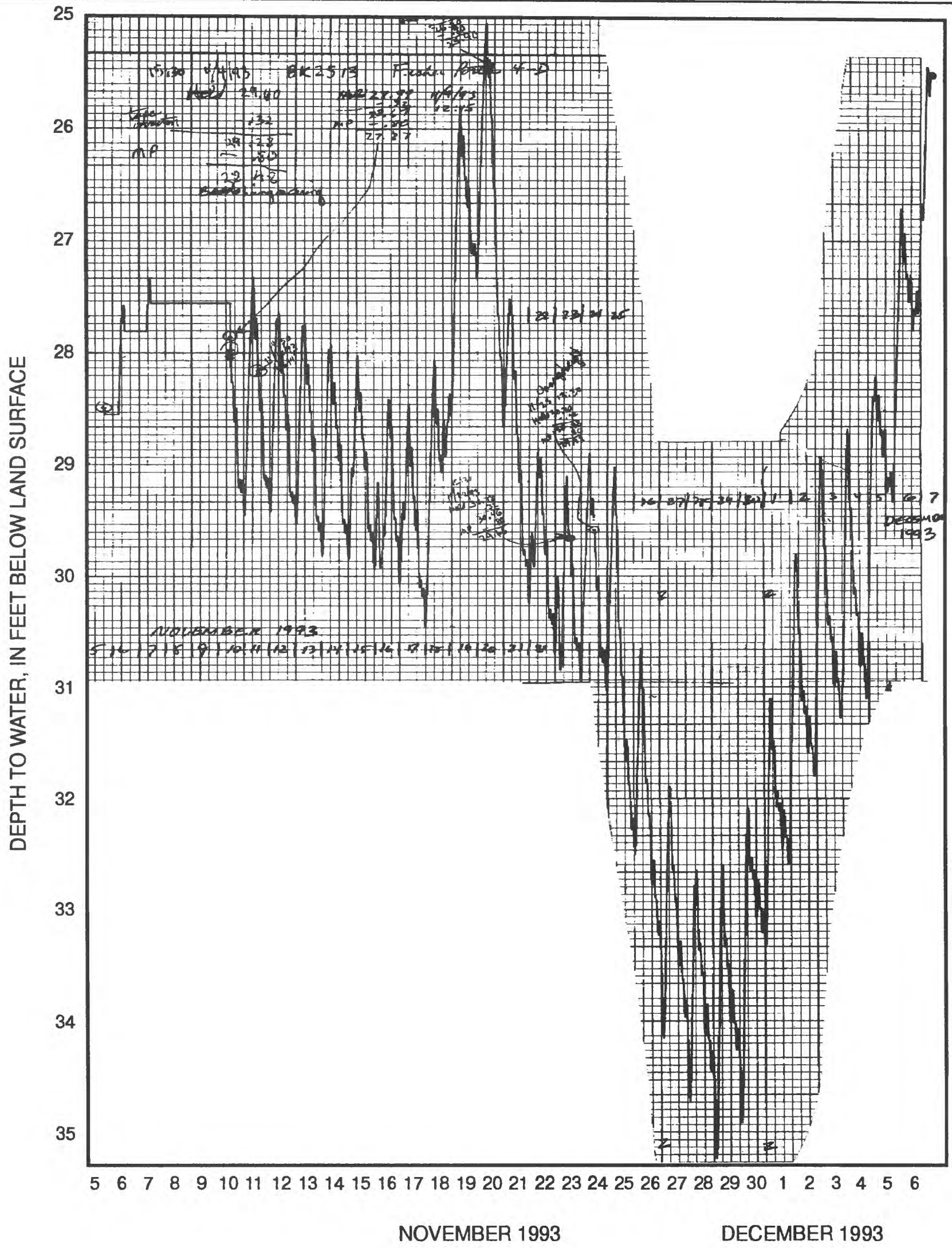

Figure 21. Hydrograph of well BK-2513, Fischer and Porter Site, Warminster, Pa., November 5 to December 6, 1993 


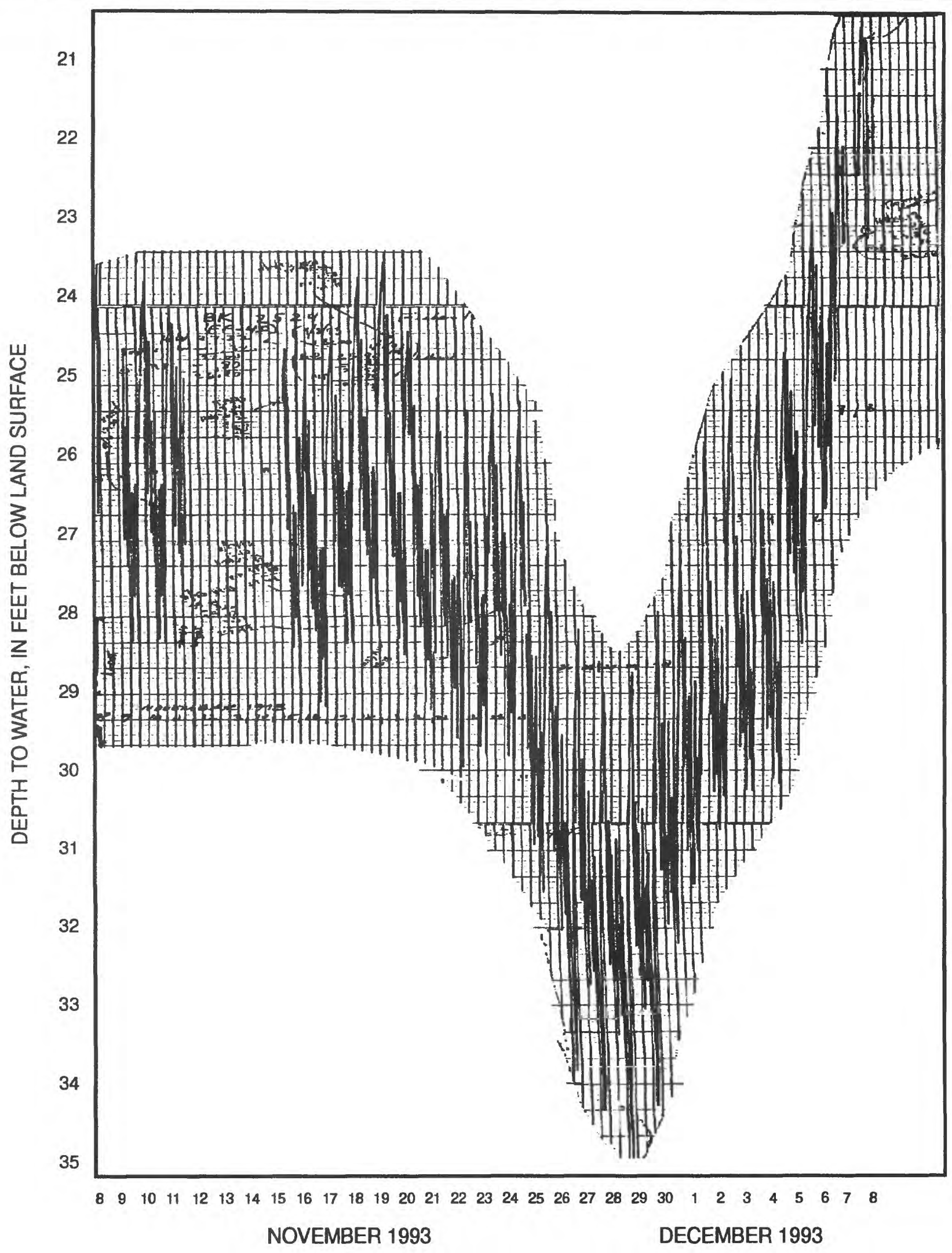

Flgure 22. Hydrograph of well BK-2524, Fischer and Porter Site, Warminster, Pa., November 8 to December 8, 1993 


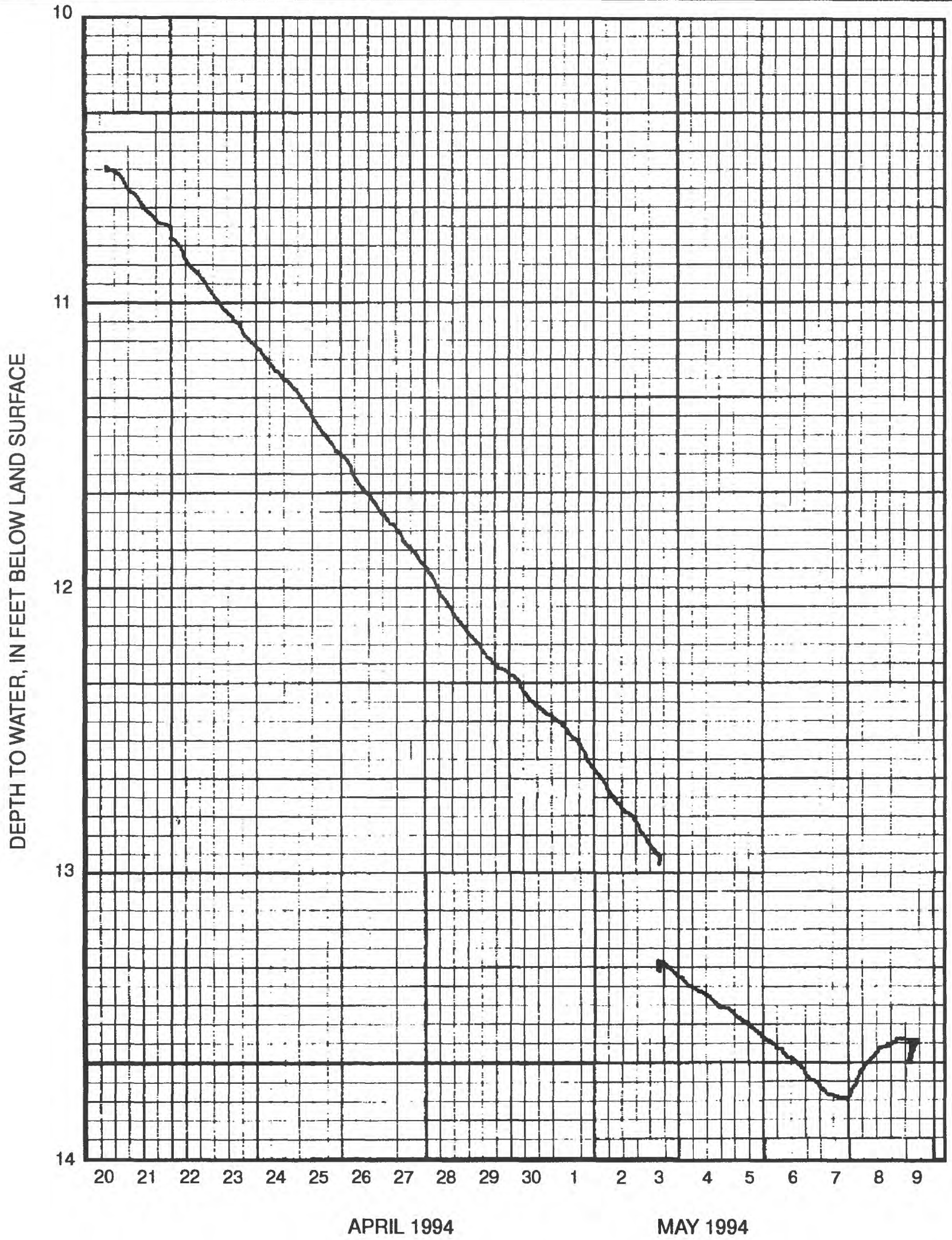

Figure 23. Hydrograph of well BK-2525, Fischer and Porter Site, Warminster, Pa., April 20 to May 9, 1994 


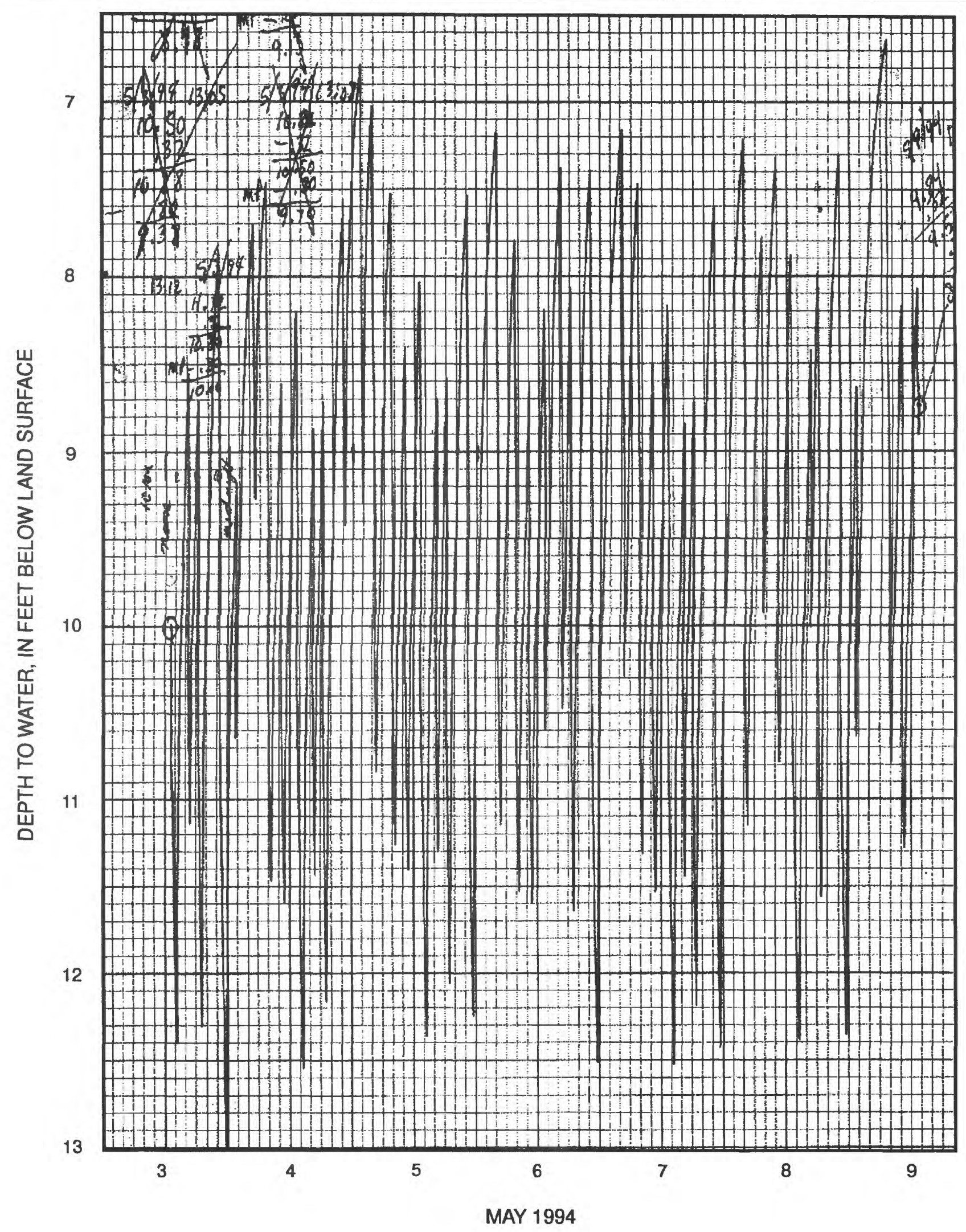

Figure 24. Hydrograph of well BK-2512, Fischer and Porter Site, Warminster, Pa., May 3-9, 1994. 


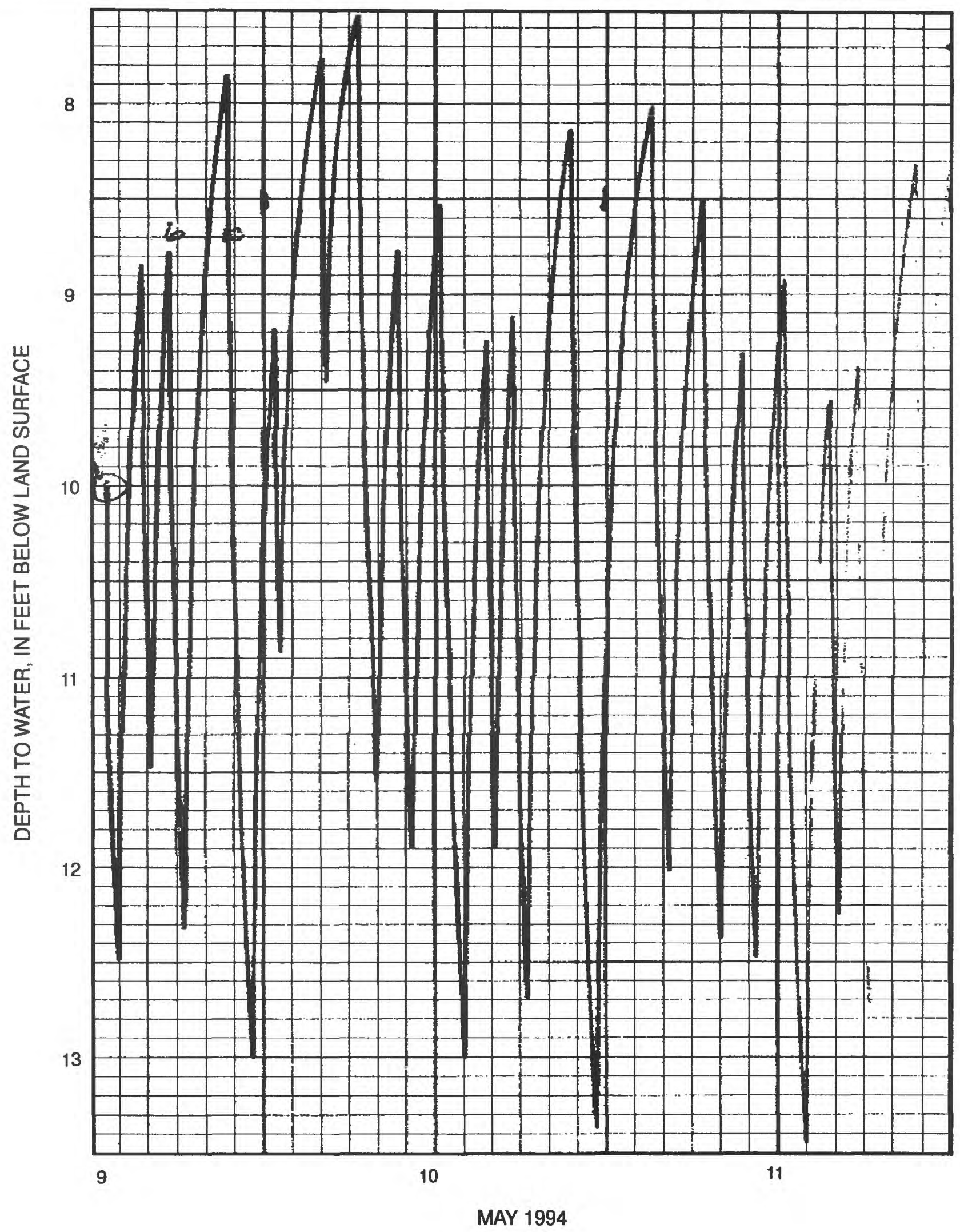

Figure 25. Hydrograph of well BK-2512, Fischer and Porter Site, Warminster, Pa., May 9-11, 1994. 


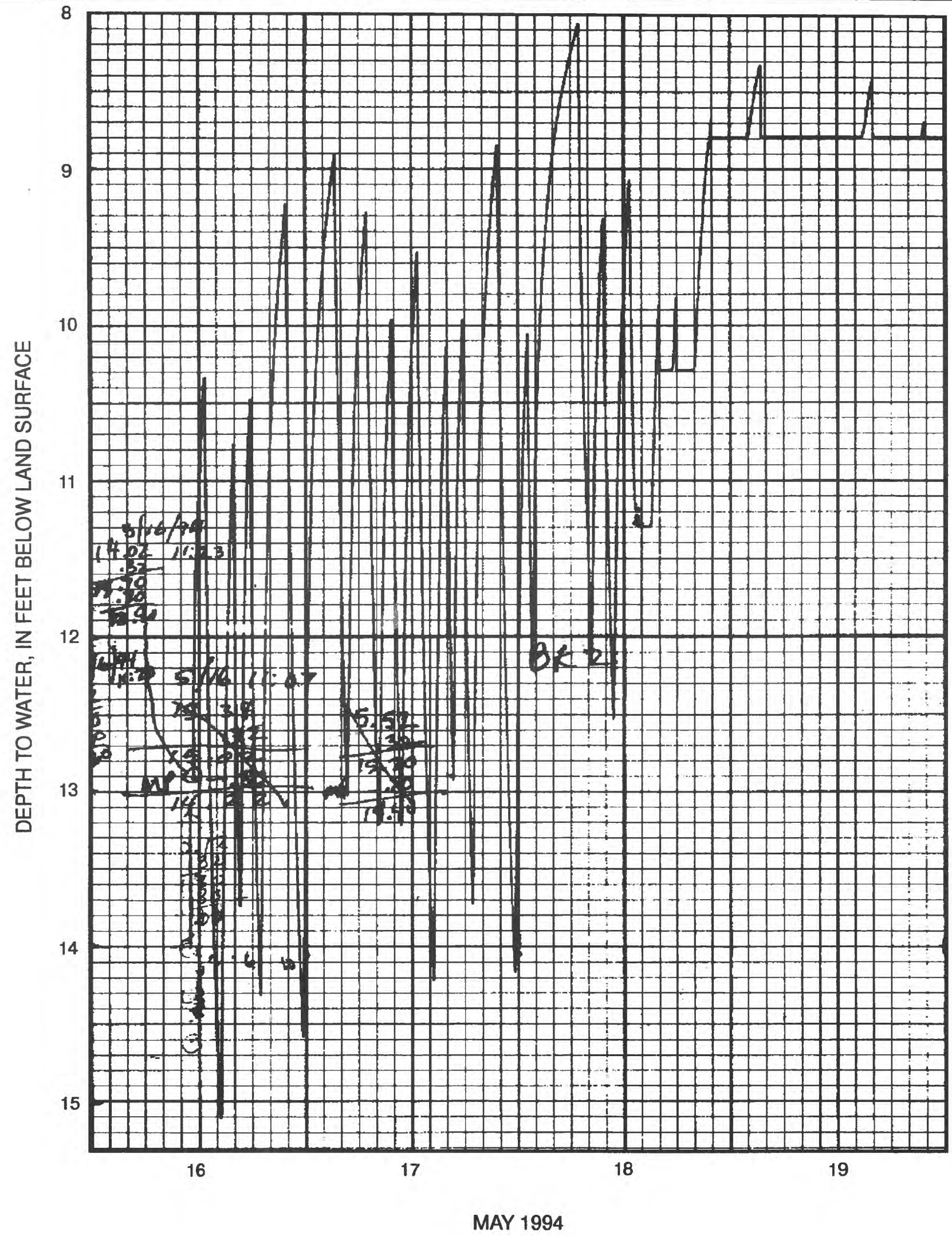

Figure 1. Hydrograph of well BK-2512, Fischer and Porter Site, Warminster, Pa., May 16-19, 1994. 


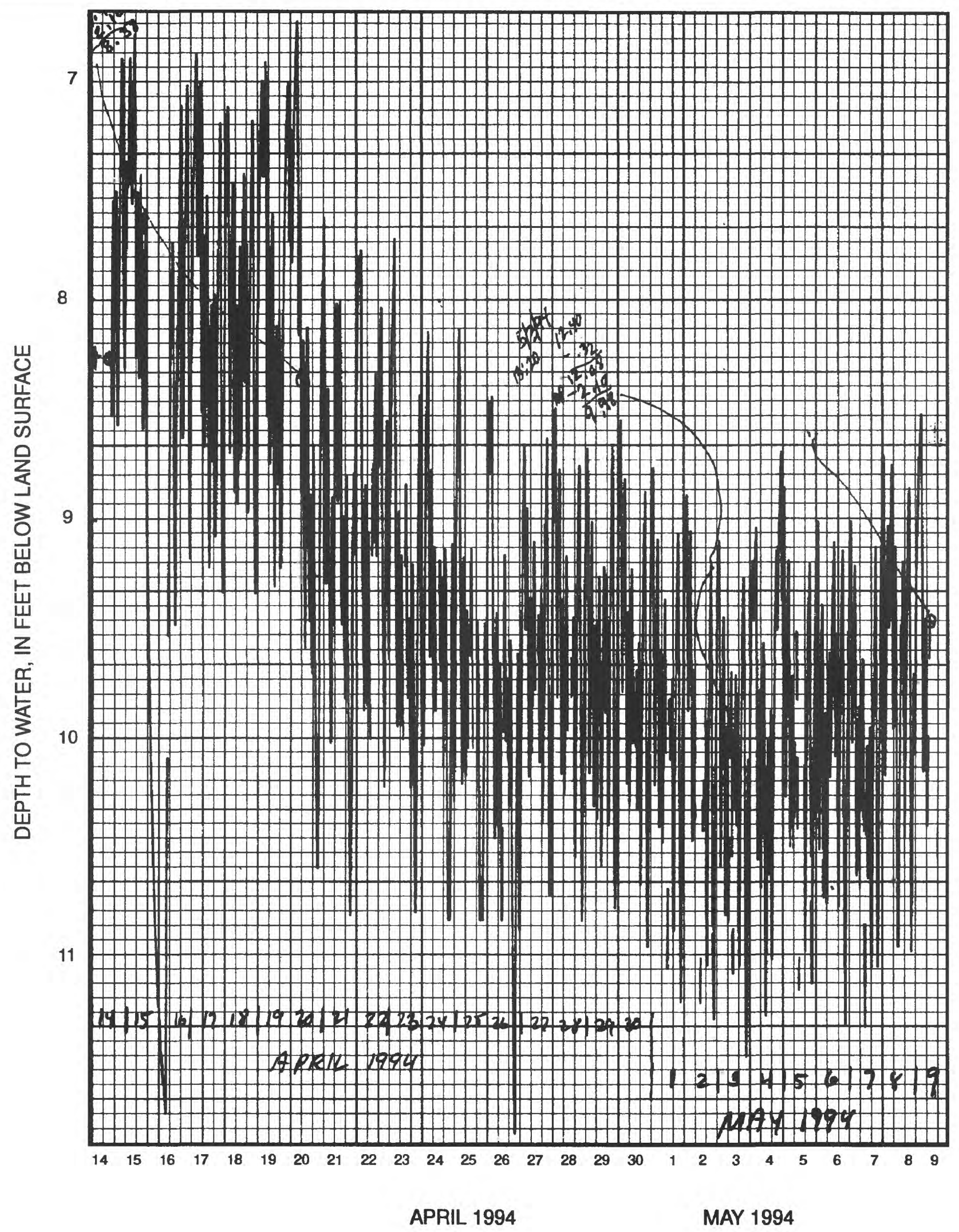

Figure 27. Hydrograph of well BK-2522, Fischer and Porter Site, Warminster, Pa., April 14 to May 9, 1994. 


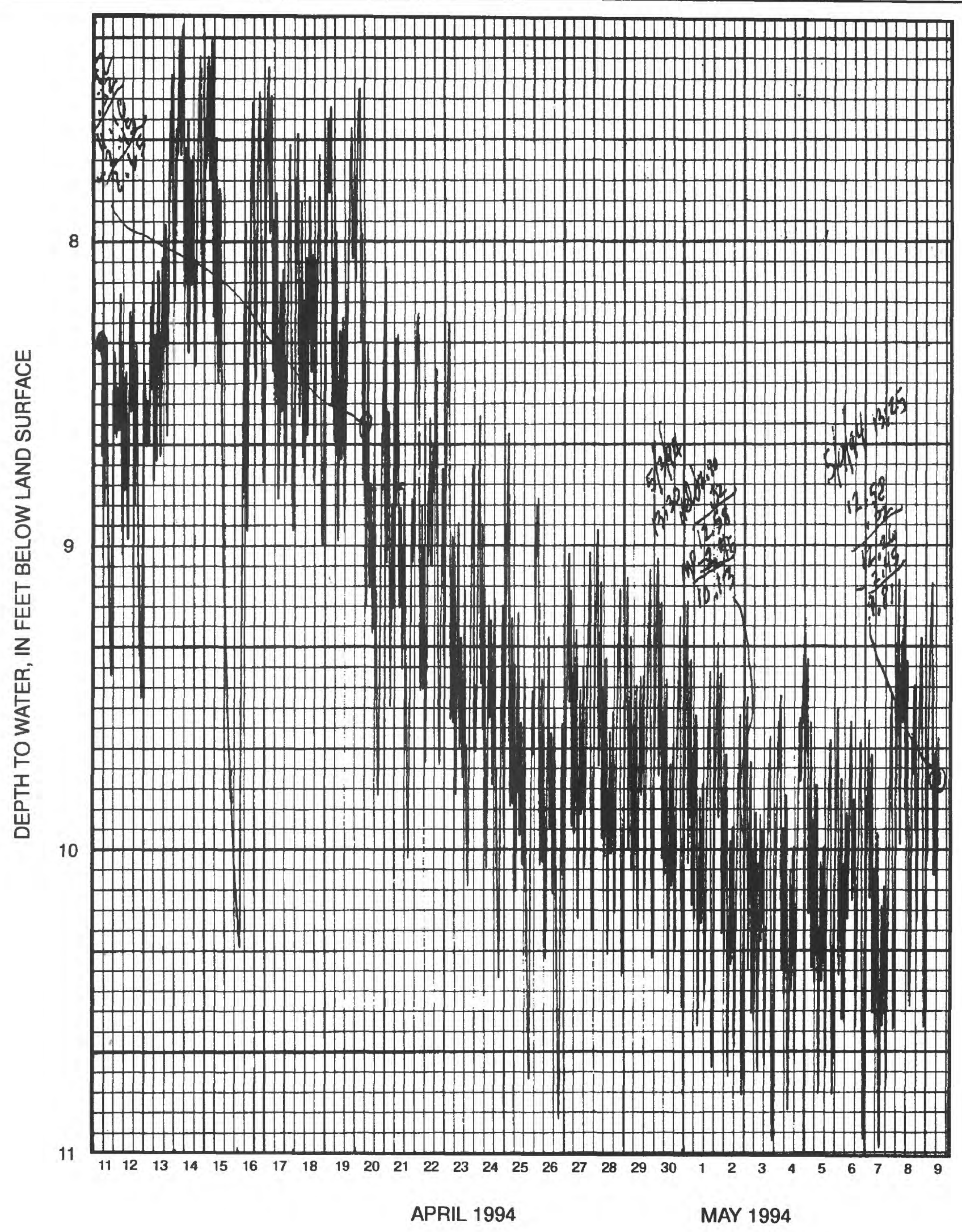

Figure 28. Hydrograph of well BK-2523, Fischer and Porter Site, Warminster, Pa., April 11 to May 9, 1994. 
Table 1. Results of chemical analyses for volatile organic compounds in water samples from borehole BK-2511, Fischer and Porter Site, Warminster, Pa.

[Concentrations given in micrograms per liter; sample from interval 277-305 feet below land surface ruined by lab; <, less than; --, no data]

\begin{tabular}{|c|c|c|c|c|c|c|c|c|}
\hline \multirow[b]{2}{*}{ - Compound } & \multicolumn{8}{|c|}{ Sampled depth interval (feet below land surface) } \\
\hline & $\begin{array}{c}\text { Above } \\
187^{1}\end{array}$ & $\begin{array}{c}\text { Above } \\
187^{2}\end{array}$ & $211-239$ & $241-269$ & $\begin{array}{l}241-269 \\
\text { replicate }\end{array}$ & $\begin{array}{c}\text { Below } \\
305\end{array}$ & $\begin{array}{l}\text { Field } \\
\text { blank }\end{array}$ & $\begin{array}{l}\text { Lab } \\
\text { blank }\end{array}$ \\
\hline Benzene & -- & 0.3 & -- & - & - & - & - & -- \\
\hline Bromoform & $<0.8$ & $<.2$ & $<0.8$ & $<0.8$ & $<0.8$ & $<0.8$ & $<0.8$ & $<0.8$ \\
\hline 1,2-Dibromomethane & $<.8$ & $<.2$ & $<.8$ & $<.8$ & $<.8$ & $<.8$ & $<.8$ & $<.8$ \\
\hline Carbon tetrachloride & $<.8$ & $<.2$ & $<.8$ & $<.8$ & $<.8$ & $<.8$ & $<.8$ & $<.8$ \\
\hline Chlorobenzene & $<.8$ & $<.2$ & $<.8$ & $<.8$ & $<.8$ & $<.8$ & $<.8$ & $<.8$ \\
\hline Dichlorobenzene & $<.8$ & $<.2$ & $<.8$ & $<.8$ & $<.8$ & $<.8$ & $<.8$ & $<.8$ \\
\hline 1,3-Dichlorobenzene & $<.8$ & $<.2$ & $<.8$ & $<.8$ & $<.8$ & $<.8$ & $<.8$ & $<.8$ \\
\hline 1,4-Dichlorobenzene & $<.8$ & $<.2$ & $<.8$ & $<.8$ & $<.8$ & $<.8$ & $<.8$ & $<.8$ \\
\hline Chlorodibromomethane & $<.8$ & $<.2$ & $<.8$ & $<.8$ & $<.8$ & $<.8$ & $<.8$ & $<.8$ \\
\hline Chloroethane & $<.8$ & $<.2$ & $<.8$ & $<.8$ & $<.8$ & $<.8$ & $<.8$ & $<.8$ \\
\hline 2-Chloroethylvinylether & $<.8$ & $<.2$ & $<.8$ & $<.8$ & $<.8$ & $<.8$ & $<.8$ & $<.8$ \\
\hline Chloroform & $<.8$ & .2 & $<.8$ & $<.8$ & $<.8$ & $<.8$ & $<.8$ & 1.8 \\
\hline Dichlorobromomethane & $<.8$ & $<.2$ & $<.8$ & $<.8$ & $<.8$ & $<.8$ & $<.8$ & $<.8$ \\
\hline Dichlorodifluoromethane & $<.8$ & $<.2$ & $<.8$ & $<.8$ & $<.8$ & $<.8$ & $<.8$ & $<.8$ \\
\hline 1,1-Dichloroethane & 1.5 & 1.3 & 1.7 & 1.4 & .9 & 1.1 & $<.8$ & $<.8$ \\
\hline 1,2-Dichloroethane & $<.8$ & $<.2$ & $<.8$ & $<.8$ & $<.8$ & $<.8$ & $<.8$ & $<.8$ \\
\hline 1,1-Dichloroethylene & 4.3 & 2.4 & 4.5 & 3.7 & 2.9 & 2.6 & $<.8$ & $<.8$ \\
\hline cis-1,2-Dichloroethene & 17 & 14 & 19 & 15 & 12 & 14 & $<.8$ & $<.8$ \\
\hline trans-1,2-Dichloroethene & $<.8$ & - & $<.8$ & $<.8$ & $<.8$ & $<.8$ & $<.8$ & $<.8$ \\
\hline 1,2-Dichloropropane & 2.3 & $<.4$ & $<, 8$ & $<.8$ & $<.8$ & $<.8$ & $<.8$ & $<.8$ \\
\hline 1,3-Dichloropropene & $<.8$ & $<.2$ & $<.8$ & $<.8$ & $<.8$ & $<.8$ & $<.8$ & $<.8$ \\
\hline cis-1,3-Dichloropropene & $<.8$ & $<.2$ & $<.8$ & $<.8$ & $<.8$ & $<.8$ & $<.8$ & $<.8$ \\
\hline trans-1,3-Dichloropropene & $<.8$ & $<.2$ & $<.8$ & $<.8$ & $<.8$ & $<.8$ & $<.8$ & $<.8$ \\
\hline Ethylbenzene & - & $<.2$ & - & - & - & - & - & - \\
\hline Methylbromide & $<.8$ & $<.2$ & $<.8$ & $<.8$ & $<.8$ & $<.8$ & $<.8$ & $<.8$ \\
\hline Methylchloride & $<.8$ & $<.2$ & $<.8$ & $<.8$ & $<.8$ & $<.8$ & $<.8$ & $<.8$ \\
\hline Methylene chloride & $<.8$ & $<.2$ & $<.8$ & $<.8$ & $<.8$ & $<.8$ & $<.8$ & $<.8$ \\
\hline Styrene & $<.8$ & $<.2$ & $<.8$ & $<.8$ & $<.8$ & $<.8$ & $<.8$ & $<.8$ \\
\hline 1,1,2,2-Tetrachloroethane & $<.8$ & $<.2$ & $<.8$ & $<.8$ & $<.8$ & $<.8$ & $<.8$ & $<.8$ \\
\hline Tetrachloroethylene & 14 & 5.7 & 14 & 11 & 7.9 & 8.6 & $<.8$ & $<.8$ \\
\hline Toluene & - & $<.2$ & - & - & - & - & - & - \\
\hline 1,1,1-Trichloroethane & 2.8 & $<.6$ & 1.9 & 1.2 & $<.8$ & $<.8$ & $<.8$ & $<.8$ \\
\hline 1,1,2-Trichloroethane & $<.8$ & $<.3$ & $<.8$ & $<.8$ & $<.8$ & $<.8$ & $<.8$ & $<.8$ \\
\hline Trichloroethylene & 88 & 130 & 87 & 78 & 74 & 73 & $<.8$ & 1.6 \\
\hline Trichlorofluoromethane & $<.8$ & $<.2$ & $<.8$ & $<.8$ & $<.8$ & $<.8$ & $<.8$ & $<.8$ \\
\hline Vinyl chloride & $<.8$ & $<.2$ & $<.8$ & $<.8$ & $<.8$ & $<.8$ & $<.8$ & $<.8$ \\
\hline Xylene & $<.8$ & $<.2$ & $<.8$ & $<.8$ & $<.8$ & $<.8$ & $<.8$ & $<.8$ \\
\hline
\end{tabular}

${ }^{1}$ U.S. Geological Survey New Jersey District Laboratory.

2 U.S. Geological Survey National Water Quality Laboratory, Arvada, Colorado. 
Table 2. Results of chemical analyses for volatile organic compounds in water samples from borehole BK-2512, Fischer and Porter Site, Warminster, Pa.

[Concentrations given in micrograms per liter; <, less than; --, no data]

\begin{tabular}{|c|c|c|c|c|c|c|c|c|c|c|c|}
\hline \multirow[b]{2}{*}{ Compound } & \multicolumn{11}{|c|}{ Sampled depth interval (feet below land surface) } \\
\hline & $\begin{array}{c}\text { Above } \\
115^{1}\end{array}$ & $\begin{array}{c}\text { Above } \\
115^{2}\end{array}$ & $132-160$ & $\begin{array}{l}132-160 \\
\text { replicate }\end{array}$ & 164-192 & 204-235 & 204-235 & 237-265 & $\begin{array}{c}\text { Below } \\
265\end{array}$ & $\begin{array}{l}\text { Field } \\
\text { blank }\end{array}$ & $\begin{array}{l}\text { Lab } \\
\text { blank }\end{array}$ \\
\hline Benzene & - & $<0.2$ & - & - & - & - & - & - & - & - & - \\
\hline Bromoform & $<0.8$ & $<.2$ & $<0.8$ & $<0.8$ & $<0.8$ & $<0.8$ & $<0.8$ & $<0.8$ & $<0.8$ & $<0.8$ & $<0.8$ \\
\hline 1,2-Dibromomethane & $<.8$ & $<.2$ & $<.8$ & $<.8$ & $<.8$ & $<.8$ & $<.8$ & $<.8$ & $<.8$ & $<.8$ & $<.8$ \\
\hline Carbon tetrachloride & $<.8$ & $<.2$ & $<.8$ & $<.8$ & $<.8$ & $<.8$ & $<.8$ & $<.8$ & $<.8$ & $<.8$ & $<.8$ \\
\hline Chlorobenzene & $<.8$ & $<.2$ & $<.8$ & $<.8$ & $<.8$ & $<.8$ & $<.8$ & $<.8$ & $<.8$ & $<.8$ & $<.8$ \\
\hline Dichlorobenzene & $<.8$ & $<.2$ & $<.8$ & $<.8$ & $<.8$ & $<.8$ & $<.8$ & $<.8$ & $<.8$ & $<.8$ & $<.8$ \\
\hline 1,3-Dichlorobenzene & $<.8$ & $<.2$ & $<.8$ & $<.8$ & $<.8$ & $<.8$ & $<.8$ & $<.8$ & $<.8$ & $<.8$ & $<.8$ \\
\hline 1,4-Dichlorobenzene & $<.8$ & $<.2$ & $<.8$ & $<.8$ & $<.8$ & $<.8$ & $<.8$ & $<.8$ & $<.8$ & $<.8$ & $<.8$ \\
\hline Chlorodibromomethane & $<.8$ & $<.2$ & $<.8$ & $<.8$ & $<.8$ & $<.8$ & $<.8$ & $<.8$ & $<.8$ & $<.8$ & $<.8$ \\
\hline Chloroethane & $<.8$ & $<.2$ & $<.8$ & $<.8$ & $<.8$ & $<.8$ & $<.8$ & $<.8$ & $<.8$ & $<.8$ & $<.8$ \\
\hline 2-Chloroethylvinylether & $<.8$ & $<.2$ & $<.8$ & $<.8$ & $<.8$ & $<.8$ & $<.8$ & $<.8$ & $<.8$ & $<.8$ & $<.8$ \\
\hline Chloroform & $<.8$ & .6 & 3.8 & 3.9 & $<.8$ & $<.8$ & $<.8$ & $<.8$ & $<.8$ & $<.8$ & 1.5 \\
\hline Dichlorobromomethane & $<.8$ & $<.2$ & $<.8$ & $<.8$ & $<.8$ & $<.8$ & $<.8$ & $<.8$ & $<.8$ & $<.8$ & $<.8$ \\
\hline Dichlorodifluoromethane & $<.8$ & $<.2$ & $<.8$ & $<.8$ & $<.8$ & $<.8$ & $<.8$ & $<.8$ & $<.8$ & $<.8$ & $<.8$ \\
\hline 1,1-Dichloroethane & $<.8$ & 1.2 & $<.8$ & $<.8$ & $<.8$ & $<.8$ & $<.8$ & $<.8$ & 1.6 & $<.8$ & $<.8$ \\
\hline 1,2-Dichloroethane & $<.8$ & $<.2$ & 8.3 & 7.7 & 2.1 & 1.9 & 2.2 & 1.8 & $<.8$ & $<.8$ & $<.8$ \\
\hline 1,1-Dichloroethylene & $<.8$ & .8 & 5.5 & 5.2 & 1.0 & $<.8$ & $<.8$ & $<.8$ & 2.0 & $<.8$ & $<.8$ \\
\hline cis-1,2-Dichloroethene & 8.2 & 13 & 55 & 56 & 30 & 25 & 29 & 29 & 27 & $<.8$ & $<.8$ \\
\hline trans-1,2-Dichloroethene & $<.8$ & - & $<.8$ & $<.8$ & $<.8$ & $<.8$ & $<.8$ & $<.8$ & $<.8$ & $<.8$ & $<.8$ \\
\hline 1,2-Dichloropropane & $<.8$ & $<.2$ & $<.8$ & $<.8$ & $<.8$ & $<.8$ & $<.8$ & $<.8$ & $<.8$ & $<.8$ & $<.8$ \\
\hline 1,3-Dichloropropene & $<.8$ & $<.2$ & $<.8$ & $<.8$ & $<.8$ & $<.8$ & $<.8$ & $<.8$ & $<.8$ & $<.8$ & $<.8$ \\
\hline cis-1,3-Dichloropropene & $<.8$ & $<.2$ & $<.8$ & $<.8$ & $<.8$ & $<.8$ & $<.8$ & $<.8$ & $<.8$ & $<.8$ & $<.8$ \\
\hline trans-1,3-Dichloropropene & $<.8$ & $<.2$ & $<.8$ & $<.8$ & $<.8$ & $<.8$ & $<.8$ & $<.8$ & $<.8$ & $<.8$ & $<.8$ \\
\hline Ethylbenzene & - & $<.2$ & - & - & - & - & - & - & - & - & - \\
\hline Methylbromide & $<.8$ & $<.2$ & $<.8$ & $<.8$ & $<.8$ & $<.8$ & $<.8$ & $<.8$ & $<.8$ & $<.8$ & $<.8$ \\
\hline Methylchloride & $<.8$ & $<.2$ & $<.8$ & $<.8$ & $<.8$ & $<.8$ & $<.8$ & $<.8$ & $<.8$ & $<.8$ & $<.8$ \\
\hline Methylene chloride & $<.8$ & $<.2$ & $<.8$ & $<.8$ & $<.8$ & $<.8$ & $<.8$ & $<.8$ & $<.8$ & 15 & $<.8$ \\
\hline Styrene & $<.8$ & $<.2$ & $<.8$ & $<.8$ & $<.8$ & $<.8$ & $<.8$ & $<.8$ & $<.8$ & $<.8$ & $<.8$ \\
\hline 1,1,2,2-Tetrachloroethane & $<.8$ & $<.2$ & $<.8$ & $<.8$ & $<.8$ & $<.8$ & $<.8$ & $<.8$ & $<.8$ & $<.8$ & $<.8$ \\
\hline Tetrachloroethylene & 5.9 & 5.6 & 37 & 37 & 12 & 11 & 11 & $<.8$ & 13 & $<.8$ & $<.8$ \\
\hline Toluene & - & $<.2$ & - & - & - & - & - & - & -- & - & - \\
\hline 1,1,1-Trichloroethane & $<.8$ & .6 & 1.8 & 1.8 & $<.8$ & .9 & $<.8$ & $<.8$ & 1.3 & 6.8 & $<.8$ \\
\hline 1,1,2-Trichloroethane & $<.8$ & $<.2$ & $<.8$ & $<.8$ & $<.8$ & $<.8$ & $<.8$ & $<.8$ & $<.8$ & $<.8$ & $<.8$ \\
\hline Trichloroethylene & 56 & 73 & 96 & 110 & 75 & 75 & 74 & 76 & 82 & $<.8$ & $<.8$ \\
\hline Trichlorofluoromethane & $<.8$ & $<.2$ & $<.8$ & $<.8$ & $<.8$ & $<.8$ & $<.8$ & $<.8$ & $<.8$ & $<.8$ & $<.8$ \\
\hline Vinyl chloride & $<.8$ & $<.2$ & 5.8 & 5.6 & $<.8$ & $<.8$ & $<.8$ & $<.8$ & $<.8$ & $<.8$ & $<.8$ \\
\hline Xylene & $<.8$ & $<.2$ & $<.8$ & $<.8$ & $<.8$ & $<.8$ & $<.8$ & $<.8$ & $<.8$ & $<.8$ & $<.8$ \\
\hline
\end{tabular}

1 U.S. Geological Survey New Jersey District Laboratory.

2 U.S. Geological Survey National Water Quality Laboratory, Arvada, Colorado. 
Table 3. Results of chemical analyses for volatile organic compounds in water samples from borehole BK-2513, Fischer and Porter Site, Warminster, Pa.

[Concentrations given in micrograms per liter; <, less than; --, no data]

\begin{tabular}{|c|c|c|c|c|c|c|c|c|c|c|c|}
\hline \multirow[b]{2}{*}{ Compound } & \multicolumn{11}{|c|}{ Sampled depth interval (feet below land surface) } \\
\hline & $\begin{array}{c}\text { Above } \\
143\end{array}$ & $143-171^{1}$ & $143-171^{2}$ & $176-204$ & $\begin{array}{l}176-204 \\
\text { replicate }\end{array}$ & 202-232 & $\begin{array}{l}202-232 \\
\text { replicate }\end{array}$ & $232-260$ & $\begin{array}{c}\text { Below } \\
260\end{array}$ & $\begin{array}{l}\text { Field } \\
\text { blank }\end{array}$ & $\begin{array}{l}\text { Lab } \\
\text { blank }\end{array}$ \\
\hline Benzene & $<0.8$ & $<0.8$ & $<0.2$ & $<0.8$ & $<0.8$ & 1.4 & 12 & 1.8 & $<0.8$ & $<0.8$ & 3.2 \\
\hline Bromoform & $<.8$ & $<.8$ & $<.2$ & $<.8$ & $<.8$ & $<.8$ & $<.8$ & $<.8$ & $<.8$ & $<.8$ & $<.8$ \\
\hline 1,2-Dibromomethane & $<.8$ & $<.8$ & $<.2$ & $<.8$ & $<.8$ & $<.8$ & $<.8$ & $<.8$ & $<.8$ & $<.8$ & $<.8$ \\
\hline Carbon tetrachloride & $<.8$ & $<.8$ & $<.2$ & $<.8$ & $<.8$ & $<.8$ & $<.8$ & $<.8$ & $<.8$ & $<.8$ & $<.8$ \\
\hline Chlorobenzene & $<.8$ & $<.8$ & $<.2$ & $<.8$ & $<.8$ & $<.8$ & $<.8$ & $<.8$ & $<.8$ & $<.8$ & $<.8$ \\
\hline Dichlorobenzene & $<.8$ & $<.8$ & $<.2$ & $<.8$ & $<.8$ & $<.8$ & $<.8$ & $<.8$ & $<.8$ & $<.8$ & $<.8$ \\
\hline 1,3-Dichlorobenzene & $<.8$ & $<.8$ & $<.2$ & $<.8$ & $<.8$ & $<.8$ & $<.8$ & $<.8$ & $<.8$ & $<.8$ & $<.8$ \\
\hline 1,4-Dichlorobenzene & $<.8$ & $<.8$ & $<.2$ & $<.8$ & $<.8$ & $<.8$ & $<.8$ & $<.8$ & $<.8$ & $<.8$ & $<.8$ \\
\hline Chlorodibromomethane & $<.8$ & $<.8$ & $<.2$ & $<.8$ & $<.8$ & $<.8$ & $<.8$ & $<.8$ & $<.8$ & $<.8$ & $<.8$ \\
\hline Chloroethane & $<.8$ & $<.8$ & $<.2$ & $<.8$ & $<.8$ & $<.8$ & $<.8$ & $<.8$ & $<.8$ & $<.8$ & $<.8$ \\
\hline 2-Chloroethylvinylether & $<.8$ & $<.8$ & $<.2$ & $<.8$ & $<.8$ & $<.8$ & $<.8$ & $<.8$ & $<.8$ & $<.8$ & $<.8$ \\
\hline Chloroform & $<.8$ & $<.8$ & 1.0 & $<.8$ & $<.8$ & $<.8$ & $<.8$ & $<.8$ & $<.8$ & $<.8$ & 1.8 \\
\hline Dichlorobromomethane & $<.8$ & $<.8$ & $<.2$ & $<.8$ & $<.8$ & $<.8$ & $<.8$ & $<.8$ & $<.8$ & $<.8$ & $<.8$ \\
\hline Dichlorodifluoromethane & $<.8$ & $<.8$ & $<.2$ & $<.8$ & $<.8$ & $<.8$ & $<.8$ & $<.8$ & $<.8$ & $<.8$ & $<.8$ \\
\hline 1,1-Dichloroethane & $<.8$ & $<.8$ & .3 & $<.8$ & $<.8$ & $<.8$ & $<.8$ & $<.8$ & $<.8$ & $<.8$ & $<.8$ \\
\hline 1,2-Dichloroethane & 29 & 35 & $<.2$ & 23 & 23 & 27 & 24 & 6.5 & 6.7 & $<.8$ & $<.8$ \\
\hline 1,1-Dichloroethylene & $<.8$ & $<.8$ & 1.2 & $<.8$ & $<.8$ & $<.8$ & $<.8$ & $<.8$ & $<.8$ & $<.8$ & $<.8$ \\
\hline cis-1,2-Dichloroethene & $<.8$ & $<.8$ & 1.5 & $<.8$ & $<.8$ & $<.8$ & $<.8$ & $<.8$ & $<.8$ & $<.8$ & $<.8$ \\
\hline trans-1,2-Dichloroethene & $<.8$ & $<.8$ & - & $<.8$ & $<.8$ & $<.8$ & $<.8$ & $<.8$ & $<.8$ & $<.8$ & $<.8$ \\
\hline 1,2-Dichloropropane & $<.8$ & $<.8$ & $<.2$ & $<.8$ & $<.8$ & $<.8$ & $<.8$ & $<.8$ & $<.8$ & $<.8$ & $<.8$ \\
\hline 1,3-Dichloropropene & $<.8$ & $<.8$ & $<.2$ & $<.8$ & $<.8$ & $<.8$ & $<.8$ & $<.8$ & $<.8$ & $<.8$ & $<.8$ \\
\hline cis-1,3-Dichloropropene & $<.8$ & $<.8$ & $<.2$ & $<.8$ & $<.8$ & $<.8$ & $<.8$ & $<.8$ & $<.8$ & $<.8$ & $<.8$ \\
\hline trans-1,3-Dichloropropene & $<.8$ & $<.8$ & $<.2$ & $<.8$ & $<.8$ & $<.8$ & $<.8$ & $<.8$ & $<.8$ & $<.8$ & $<.8$ \\
\hline Ethylbenzene & $<.8$ & $<.8$ & $<.2$ & $<.8$ & $<.8$ & $<.8$ & $<.8$ & $<.8$ & 2.5 & $<.8$ & $<.8$ \\
\hline Methylbromide & $<.8$ & $<.8$ & $<.2$ & $<.8$ & $<.8$ & $<.8$ & $<.8$ & $<.8$ & $<.8$ & $<.8$ & $<.8$ \\
\hline Methylchloride & $<.8$ & $<.8$ & $<.2$ & $<.8$ & $<.8$ & $<.8$ & $<.8$ & $<.8$ & $<.8$ & $<.8$ & $<.8$ \\
\hline Methylene chloride & $<.8$ & $<.8$ & $<.2$ & $<.8$ & $<.8$ & $<.8$ & $<.8$ & $<.8$ & $<.8$ & $<.8$ & $<.8$ \\
\hline Styrene & $<.8$ & $<.8$ & $<.2$ & $<.8$ & $<.8$ & $<.8$ & $<.8$ & $<.8$ & $<.8$ & $<.8$ & $<.8$ \\
\hline 1,1,2,2-Tetrachloroethane & $<.8$ & $<.8$ & $<.2$ & $<.8$ & $<.8$ & $<.8$ & $<.8$ & $<.8$ & $<.8$ & $<.8$ & $<.8$ \\
\hline Tetrachloroethylene & 10 & 11 & 10 & 4.5 & 4.4 & 2.3 & 2.2 & 3.8 & 4.4 & $<.8$ & $<.8$ \\
\hline Toluene & $<.8$ & 3.6 & .2 & 3.1 & 3.4 & $<.8$ & $<.8$ & 11 & 2.5 & 20 & 1.3 \\
\hline 1,1,1-Trichloroethane & 1.2 & 1.4 & 1.9 & $<.8$ & $<.8$ & 1.7 & $<.8$ & 2.5 & .8 & $<.8$ & $<.8$ \\
\hline 1,1,2-Trichloroethane & $<.8$ & $<.8$ & $<.2$ & $<.8$ & $<.8$ & $<.8$ & $<.8$ & $<.8$ & $<.8$ & $<.8$ & $<.8$ \\
\hline Trichloroethylene & 39 & 43 & 28 & 34 & 33 & 37 & 34 & 20 & 20 & $<.8$ & 1.6 \\
\hline Trichlorofluoromethane & $<.8$ & $<.8$ & $<.2$ & $<.8$ & $<.8$ & $<.8$ & $<.8$ & $<.8$ & $<.8$ & $<.8$ & $<.8$ \\
\hline Vinyl chloride & $<.8$ & $<.8$ & $<.2$ & $<.8$ & $<.8$ & $<.8$ & $<.8$ & $<.8$ & $<.8$ & $<.8$ & $<.8$ \\
\hline Xylene & $<.8$ & $<.8$ & $<.2$ & $<.8$ & $<.8$ & $<.8$ & $<.8$ & $<.8$ & $<.8$ & $<.8$ & $<.8$ \\
\hline
\end{tabular}

1U.S. Geological Survey New Jersey District Laboratory.

2 U.S. Geological Sunvey National Water Quality Laboratory, Anvada, Colorado. 
Table 4. Results of chemical analyses for volatile organic compounds in water samples from borehole BK-2514, Fischer and Porter Site, Warminster, Pa.

[Concentrations given in micrograms per liter; <, less than; -- , no data]

\begin{tabular}{|c|c|c|c|c|c|c|c|c|c|c|c|c|}
\hline \multirow[b]{2}{*}{ Compound } & \multicolumn{12}{|c|}{ Sampled depth interval (feet below land surface) } \\
\hline & Above $72^{1}$ & Above $72^{2}$ & $72-100$ & $100-128$ & $130-158$ & $177-205$ & 209-237 & $\begin{array}{l}209-237 \\
\text { replicate }\end{array}$ & $\begin{array}{c}\text { Below } \\
237\end{array}$ & $\begin{array}{c}\text { Below } 237 \\
\text { replicate }\end{array}$ & $\begin{array}{l}\text { Field } \\
\text { blank }\end{array}$ & $\begin{array}{l}\text { Lab } \\
\text { blank }\end{array}$ \\
\hline Benzene & - & $<0.2$ & - & - & - & - & - & $\overline{-}$ & - & - & - & - \\
\hline Bromoform & $<0.8$ & $<.2$ & $<0.8$ & $<0.8$ & $<0.8$ & $<0.8$ & $<0.8$ & $<0.8$ & $<0.8$ & $<0.8$ & $<0.8$ & $<0.8$ \\
\hline 1,2-Dibromomethane & $<.8$ & $<.2$ & $<.8$ & $<.8$ & $<.8$ & $<.8$ & $<.8$ & $<.8$ & $<.8$ & $<.8$ & $<.8$ & $<.8$ \\
\hline Carbon tetrachloride & $<.8$ & $<.2$ & $<.8$ & $<.8$ & $<.8$ & $<.8$ & $<.8$ & $<.8$ & $<.8$ & $<.8$ & $<.8$ & $<.8$ \\
\hline Chlorobenzene & $<.8$ & $<.2$ & $<.8$ & $<.8$ & $<.8$ & $<.8$ & $<.8$ & $<.8$ & $<.8$ & $<.8$ & $<.8$ & $<.8$ \\
\hline Dichlorobenzene & $<.8$ & $<.2$ & $<.8$ & $<.8$ & $<.8$ & $<.8$ & $<.8$ & $<.8$ & $<.8$ & $<.8$ & $<.8$ & $<.8$ \\
\hline 1,3-Dichlorobenzene & $<.8$ & $<.2$ & $<.8$ & $<.8$ & $<.8$ & $<.8$ & $<.8$ & $<.8$ & $<.8$ & $<.8$ & $<.8$ & $<.8$ \\
\hline 1,4-Dichlorobenzene & $<.8$ & $<.2$ & $<.8$ & $<.8$ & $<.8$ & $<.8$ & $<.8$ & $<.8$ & $<.8$ & $<.8$ & $<.8$ & $<.8$ \\
\hline Chlorodibromomethane & $<.8$ & $<.2$ & $<.8$ & $<.8$ & $<.8$ & $<.8$ & $<.8$ & $<.8$ & $<.8$ & $<.8$ & $<.8$ & $<.8$ \\
\hline Chloroethane & $<.8$ & $<.2$ & $<.8$ & $<.8$ & $<.8$ & $<.8$ & $<.8$ & $<.8$ & $<.8$ & $<.8$ & $<.8$ & $<.8$ \\
\hline 2-Chloroethylvinylether & $<.8$ & $<.2$ & $<.8$ & $<.8$ & $<.8$ & $<.8$ & $<.8$ & $<.8$ & $<.8$ & $<.8$ & $<.8$ & $<.8$ \\
\hline Chloroform & $<.8$ & $<.2$ & $<.8$ & $<.8$ & $<.8$ & $<.8$ & $<.8$ & $<.8$ & $<.8$ & $<.8$ & $<.8$ & 1.4 \\
\hline Dichlorobromomethane & $<.8$ & $<.2$ & $<.8$ & $<.8$ & $<.8$ & $<.8$ & $<.8$ & $<.8$ & $<.8$ & $<.8$ & $<.8$ & $<.8$ \\
\hline Dichlorodifluoromethane & $<.8$ & $<.2$ & $<.8$ & $<.8$ & $<.8$ & $<.8$ & $<.8$ & $<.8$ & $<.8$ & $<.8$ & $<.8$ & $<.8$ \\
\hline 1,1-Dichloroethane & $<.8$ & $<.2$ & $<.8$ & $<.8$ & $<.8$ & $<.8$ & 1.1 & $<.8$ & $<.8$ & $<.8$ & $<.8$ & $<.8$ \\
\hline 1,2-Dichloroethane & 4.5 & $<.2$ & $<.8$ & $<.8$ & $<.8$ & $<.8$ & $<.8$ & $<.8$ & $<.8$ & $<.8$ & $<.8$ & $<.8$ \\
\hline 1,1-Dichloroethylene & $<.8$ & $<.2$ & $<.8$ & $<.8$ & $<.8$ & $<.8$ & $<.8$ & $<.8$ & $<.8$ & $<.8$ & $<.8$ & $<.8$ \\
\hline cis-1,2-Dichloroethene & $<.8$ & $<.2$ & $<.8$ & $<.8$ & $<.8$ & $<.8$ & $<.8$ & $<.8$ & $<.8$ & $<.8$ & $<.8$ & $<.8$ \\
\hline trans-1,2-Dichloroethene & $<.8$ & - & $<.8$ & $<.8$ & $<.8$ & $<.8$ & $<.8$ & $<.8$ & $<.8$ & $<.8$ & $<.8$ & $<.8$ \\
\hline 1,2-Dichloropropane & $<.8$ & $<.2$ & $<.8$ & $<.8$ & $<.8$ & $<.8$ & $<.8$ & $<.8$ & $<.8$ & $<.8$ & $<.8$ & $<.8$ \\
\hline 1,3-Dichloropropene & $<.8$ & $<.2$ & $<.8$ & $<.8$ & $<.8$ & $<.8$ & $<.8$ & $<.8$ & $<.8$ & $<.8$ & $<.8$ & $<.8$ \\
\hline cis-1,3-Dichloropropene & $<.8$ & $<.2$ & $<.8$ & $<.8$ & $<.8$ & $<.8$ & $<.8$ & $<.8$ & $<.8$ & $<.8$ & $<.8$ & $<.8$ \\
\hline trans-1,3-Dichloropropene & $<.8$ & $<.2$ & $<.8$ & $<.8$ & $<.8$ & $<.8$ & $<.8$ & $<.8$ & $<.8$ & $<.8$ & $<.8$ & $<.8$ \\
\hline Ethylbenzene & - & $<2$ & - & - & - & - & - & - & - & - & - & - \\
\hline Methylbromide & $<.8$ & $<.2$ & $<.8$ & $<.8$ & $<.8$ & $<.8$ & $<.8$ & $<.8$ & $<.8$ & $<.8$ & $<.8$ & $<.8$ \\
\hline Methylchloride & $<.8$ & $<.2$ & $<.8$ & $<.8$ & $<.8$ & $<.8$ & $<.8$ & $<.8$ & $<.8$ & $<8$ & $<.8$ & $<.8$ \\
\hline Methylene chloride & $<.8$ & $<.2$ & $<.8$ & $<.8$ & $<.8$ & $<.8$ & $<.8$ & $<.8$ & $<.8$ & $<.8$ & 19 & $<.8$ \\
\hline Styrene & $<.8$ & $<.2$ & $<.8$ & $<.8$ & $<.8$ & $<.8$ & $<.8$ & $<.8$ & $<.8$ & $<.8$ & $<.8$ & $<.8$ \\
\hline 1,1,2,2-Tetrachloroethane & $<.8$ & $<.2$ & $<.8$ & $<.8$ & $<.8$ & $<.8$ & $<.8$ & $<.8$ & $<.8$ & $<.8$ & $<.8$ & $<.8$ \\
\hline Tetrachloroethylene & $<.8$ & $<.2$ & $<.8$ & $<.8$ & $<.8$ & $<.8$ & $<.8$ & $<.8$ & $<.8$ & $<.8$ & $<.8$ & $<.8$ \\
\hline Toluene & - & .4 & - & - & - & - & - & - & - & - & - & - \\
\hline 1,1,1-Trichloroethane & $<.8$ & $<.2$ & .8 & $<.8$ & 9.1 & $<.8$ & $<.8$ & $<.8$ & 1.1 & 1.1 & $<.8$ & $<.8$ \\
\hline 1,1,2-Trichloroethane & $<.8$ & $<.2$ & $<.8$ & $<.8$ & $<.8$ & $<.8$ & $<.8$ & $<.8$ & $<.8$ & $<.8$ & $<.8$ & $<.8$ \\
\hline Trichloroethylene & 9.7 & .5 & $<.8$ & $<.8$ & $<.8$ & $<.8$ & $<.8$ & $<.8$ & $<.8$ & $<.8$ & $<.8$ & $<.8$ \\
\hline Trichlorofluoromethane & $<.8$ & $<.2$ & $<.8$ & $<.8$ & $<.8$ & $<.8$ & $<.8$ & $<.8$ & $<.8$ & $<.8$ & $<.8$ & $<.8$ \\
\hline Vinyl chloride & $<.8$ & $<.2$ & $<.8$ & $<.8$ & $<.8$ & $<.8$ & $<.8$ & $<.8$ & $<.8$ & $<.8$ & $<.8$ & $<.8$ \\
\hline Xylene & $<.8$ & $<.2$ & $<.8$ & $<.8$ & $<.8$ & $<.8$ & $<.8$ & $<.8$ & $<.8$ & $<.8$ & $<.8$ & $<.8$ \\
\hline
\end{tabular}

1 U.S. Geological Survey New Jersey District Laboratory.

2 U.S. Geological Survey National Water Quality Laboratory, Arvada, Colorado. 
Table 5. Results of chemical analyses for volatile organic compounds in water samples from borehole BK-2515, Fischer and Porter Site, Warminster, Pa.

[Concentrations given in micrograms per liter; <, less than; --, no data]

\begin{tabular}{|c|c|c|c|c|c|c|c|}
\hline \multirow[b]{2}{*}{ Compound } & \multicolumn{7}{|c|}{ Sampled depth interval (feet below land surface) } \\
\hline & $\begin{array}{c}\text { Above } \\
172\end{array}$ & $172-200^{1}$ & $172-200^{2}$ & $\begin{array}{l}\text { Below } \\
277\end{array}$ & $\begin{array}{l}\text { Below } 277 \\
\text { replicate }\end{array}$ & $\begin{array}{l}\text { Field } \\
\text { blank }\end{array}$ & $\begin{array}{l}\text { Lab } \\
\text { blank }\end{array}$ \\
\hline Benzene & - & -- & $<0.2$ & - & - & -- & - \\
\hline Bromoform & $<0.8$ & $<0.8$ & $<.2$ & $<0.8$ & $<0.8$ & $<0.8$ & $<0.8$ \\
\hline 1,2-Dibromomethane & $<.8$ & $<.8$ & $<.2$ & $<.8$ & $<.8$ & $<.8$ & $<.8$ \\
\hline Carbon tetrachloride & $<.8$ & $<.8$ & $<.2$ & $<.8$ & $<.8$ & $<.8$ & $<.8$ \\
\hline Chlorobenzene & $<.8$ & $<.8$ & $<.2$ & $<.8$ & $<.8$ & $<.8$ & $<.8$ \\
\hline Dichlorobenzene & $<.8$ & $<.8$ & $<.2$ & $<.8$ & $<.8$ & $<.8$ & $<.8$ \\
\hline 1,3-Dichlorobenzene & $<.8$ & $<.8$ & $<.2$ & $<.8$ & $<.8$ & $<.8$ & $<.8$ \\
\hline 1,4-Dichlorobenzene & $<.8$ & $<.8$ & $<.2$ & $<.8$ & $<.8$ & $<.8$ & $<.8$ \\
\hline Chlorodibromomethane & $<.8$ & $<.8$ & .3 & $<.8$ & $<.8$ & $<.8$ & $<.8$ \\
\hline Chloroethane & $<.8$ & $<.8$ & $<.2$ & $<.8$ & $<.8$ & $<.8$ & $<.8$ \\
\hline 2-Chloroethylvinylether & $<.8$ & $<.8$ & $<.2$ & $<.8$ & $<.8$ & $<.8$ & $<.8$ \\
\hline Chloroform & $<.8$ & $<.8$ & .3 & $<.8$ & $<.8$ & $<.8$ & 1.4 \\
\hline Dichlorobromomethane & $<.8$ & $<.8$ & $<.2$ & $<.8$ & $<.8$ & $<.8$ & $<.8$ \\
\hline Dichlorodifluoromethane & $<.8$ & $<.8$ & $<.2$ & $<.8$ & $<.8$ & $<.8$ & $<.8$ \\
\hline 1,1-Dichloroethane & 3.1 & 1.7 & 2.1 & 2.0 & 2.0 & $<.8$ & $<.8$ \\
\hline 1,2-Dichloroethane & $<.8$ & $<.8$ & .3 & $<.8$ & $<.8$ & $<.8$ & $<.8$ \\
\hline 1,1-Dichloroethylene & 6.6 & 5.6 & 5.2 & 2.0 & 5.3 & $<.8$ & $<.8$ \\
\hline cis-1,2-Dichloroethene & 17 & 14 & 19 & 19 & 16 & $<.8$ & $<.8$ \\
\hline 1,2-Dichloropropane & $<.8$ & $<.8$ & .3 & $<.8$ & $<.8$ & $<.8$ & $<.8$ \\
\hline 1,3-Dichloropropene & $<.8$ & $<.8$ & $<.2$ & $<.8$ & $<.8$ & $<.8$ & $<.8$ \\
\hline cis-1,3-Dichloropropene & $<.8$ & $<.8$ & $<.2$ & $<.8$ & $<.8$ & $<.8$ & $<.8$ \\
\hline trans-1,3-Dichloropropene & $<.8$ & $<.8$ & $<.2$ & $<.8$ & $<.8$ & $<.8$ & $<.8$ \\
\hline Ethylbenzene & - & - & $<.2$ & - & - & -- & - \\
\hline Methylbromide & $<.8$ & $<.8$ & $<.2$ & $<.8$ & $<.8$ & $<.8$ & $<.8$ \\
\hline Methylchloride & $<.8$ & $<.8$ & $<.2$ & $<.8$ & $<.8$ & $<.8$ & $<.8$ \\
\hline Methylene chloride & $<.8$ & $<.8$ & $<.2$ & $<.8$ & $<.8$ & $<.8$ & $<.8$ \\
\hline Styrene & $<.8$ & $<.8$ & $<.2$ & $<.8$ & $<.8$ & $<.8$ & $<.8$ \\
\hline 1,1,2,2-Tetrachloroethane & $<.8$ & $<.8$ & $<.2$ & $<.8$ & $<.8$ & $<.8$ & $<.8$ \\
\hline Tetrachloroethylene & 6.3 & 7.3 & 6.4 & 7.3 & 5.6 & $<.8$ & $<.8$ \\
\hline Toluene & - & -- & .3 & - & - & -- & - \\
\hline 1,1,1-Trichloroethane & $<.8$ & $<.8$ & .8 & $<.8$ & $<.8$ & $<.8$ & $<.8$ \\
\hline 1,1,2-Trichloroethane & $<.8$ & $<.8$ & $<.2$ & $<.8$ & $<.8$ & $<.8$ & $<.8$ \\
\hline Trichloroethylene & 84 & 71 & 150 & 76 & 75 & $<.8$ & $<.8$ \\
\hline Trichlorofluoromethane & $<.8$ & $<.8$ & $<.2$ & $<.8$ & $<.8$ & $<.8$ & $<.8$ \\
\hline Vinyl chloride & 1.3 & $<.8$ & 1.4 & $<.8$ & .8 & $<.8$ & $<.8$ \\
\hline Xylene & $<.8$ & $<.8$ & $<.2$ & $<.8$ & $<.8$ & $<.8$ & $<.8$ \\
\hline
\end{tabular}

${ }^{1}$ U.S. Geological Survey New Jersey District Laboratory.

2 U.S. Geological Survey National Water Quality Laboratory, Arvada, Colorado. 
Table 6. Results of chemical analyses for volatile organic compounds in water samples from borehole MG-1242, Hatboro, Pa.

[Concentrations given in micrograms per liter; <, less than; --, no data]

\begin{tabular}{|c|c|c|c|c|c|c|c|c|}
\hline \multirow[b]{2}{*}{ Compound } & \multicolumn{8}{|c|}{ Sampled depth interval (feet below land surface) } \\
\hline & $\begin{array}{c}\text { Above } \\
90\end{array}$ & $90-115^{1}$ & $90-115^{2}$ & $120-145$ & $\begin{array}{l}120-145 \\
\text { replicate }\end{array}$ & $\begin{array}{c}\text { Below } \\
145\end{array}$ & $\begin{array}{l}\text { Field } \\
\text { blank }\end{array}$ & $\begin{array}{c}\text { Lab } \\
\text { blank }\end{array}$ \\
\hline Benzene & $<0.8$ & $<0.8$ & $<0.2$ & $<0.8$ & $<0.8$ & $<0.8$ & $<0.8$ & $<0.8$ \\
\hline Bromoform & $<.8$ & $<.8$ & $<.2$ & $<.8$ & $<.8$ & $<.8$ & $<.8$ & $<.8$ \\
\hline 1,2-Dibromomethane & $<.8$ & $<.8$ & $<.2$ & $<.8$ & $<.8$ & $<.8$ & $<.8$ & $<.8$ \\
\hline Carbon tetrachloride & $<.8$ & $<.8$ & $<.2$ & $<.8$ & $<.8$ & $<.8$ & $<.8$ & $<.8$ \\
\hline Chlorobenzene & $<.8$ & $<.8$ & $<.2$ & $<.8$ & $<.8$ & $<.8$ & $<.8$ & $<.8$ \\
\hline Dichlorobenzene & $<.8$ & $<.8$ & $<.2$ & $<.8$ & $<.8$ & $<.8$ & $<.8$ & $<.8$ \\
\hline 1,3-Dichlorobenzene & $<.8$ & $<.8$ & $<.2$ & $<.8$ & $<.8$ & $<.8$ & $<.8$ & $<.8$ \\
\hline 1,4-Dichlorobenzene & $<.8$ & $<.8$ & $<.2$ & $<.8$ & $<.8$ & $<.8$ & $<.8$ & $<.8$ \\
\hline Chlorodibromomethane & $<.8$ & $<.8$ & $<.2$ & $<.8$ & $<.8$ & $<.8$ & $<.8$ & $<.8$ \\
\hline Chloroethane & $<.8$ & $<.8$ & $<.2$ & $<.8$ & $<.8$ & $<.8$ & $<.8$ & $<.8$ \\
\hline 2-Chloroethylvinylether & $<.8$ & $<.8$ & $<.2$ & $<.8$ & $<.8$ & $<.8$ & $<.8$ & $<.8$ \\
\hline Chloroform & $<.8$ & $<.8$ & .2 & $<.8$ & $<.8$ & $<.8$ & $<.8$ & $<.8$ \\
\hline Dichlorobromomethane & $<.8$ & $<.8$ & $<.2$ & $<.8$ & $<.8$ & $<.8$ & $<.8$ & $<.8$ \\
\hline Dichlorodifluoromethane & $<.8$ & $<.8$ & $<.2$ & $<.8$ & $<.8$ & $<.8$ & $<.8$ & $<.8$ \\
\hline 1,1-Dichloroethane & $<.8$ & $<.8$ & $<.2$ & $<.8$ & $<.8$ & $<.8$ & $<.8$ & $<.8$ \\
\hline 1,2-Dichloroethane & $<.8$ & $<.8$ & $<.2$ & $<.8$ & $<.8$ & $<.8$ & $<.8$ & $<.8$ \\
\hline 1,1-Dichloroethylene & $<.8$ & $<.8$ & $<.2$ & $<.8$ & $<.8$ & $<.8$ & $<.8$ & $<.8$ \\
\hline trans-1,2-Dichloroethene & $<.8$ & $<.8$ & $<.2$ & $<.8$ & $<.8$ & $<.8$ & $<.8$ & $<.8$ \\
\hline 1,2-Dichloropropane & $<.8$ & $<.8$ & $<.2$ & $<.8$ & $<.8$ & $<.8$ & $<.8$ & $<.8$ \\
\hline 1,3-Dichloropropene & $<.8$ & $<.8$ & $<.2$ & $<.8$ & $<.8$ & $<.8$ & $<.8$ & $<.8$ \\
\hline cis-1,3-Dichloropropene & $<.8$ & $<.8$ & $<.2$ & $<.8$ & $<.8$ & $<.8$ & $<.8$ & $<.8$ \\
\hline trans-1,3-Dichloropropene & $<.8$ & $<.8$ & $<.2$ & $<.8$ & $<.8$ & $<.8$ & $<.8$ & $<.8$ \\
\hline Ethylbenzene & $<.8$ & $<.8$ & $<.2$ & $<.8$ & $<.8$ & $<.8$ & $<.8$ & .8 \\
\hline Methylbromide & $<.8$ & $<.8$ & $<.2$ & $<.8$ & $<.8$ & $<.8$ & $<.8$ & $<.8$ \\
\hline Methylchloride & $<.8$ & $<.8$ & $<.2$ & $<.8$ & $<.8$ & $<.8$ & $<.8$ & $<.8$ \\
\hline Methylene chloride & $<.8$ & $<.8$ & $<.2$ & $<.8$ & $<.8$ & $<.8$ & $<.8$ & $<.8$ \\
\hline Styrene & $<.8$ & $<.8$ & $<.2$ & $<.8$ & $<.8$ & $<.8$ & $<.8$ & $<.8$ \\
\hline 1,1,2,2-Tetrachloroethane & $<.8$ & $<.8$ & $<.2$ & $<.8$ & $<.8$ & $<.8$ & $<.8$ & $<.8$ \\
\hline Tetrachloroethylene & $<.8$ & $<.8$ & $<.2$ & $<.8$ & $<.8$ & $<.8$ & $<.8$ & $<.8$ \\
\hline Toluene & $<.8$ & $<.8$ & $<.2$ & $<.8$ & $<.8$ & $<.8$ & $<.8$ & 11.8 \\
\hline 1,1,1-Trichloroethane & $<.8$ & $<.8$ & .3 & $<.8$ & $<.8$ & $<.8$ & $<.8$ & $<.8$ \\
\hline 1,1,2-Trichloroethane & $<.8$ & $<.8$ & $<.2$ & $<.8$ & $<.8$ & $<.8$ & $<.8$ & $<.8$ \\
\hline Trichloroethylene & $<.8$ & 1.0 & 1.3 & 1.2 & .8 & $<.8$ & $<.8$ & $<.8$ \\
\hline Trichlorofluoromethane & $<.8$ & $<.8$ & $<.2$ & $<.8$ & $<.8$ & $<.8$ & $<.8$ & $<.8$ \\
\hline Vinyl chloride & $<.8$ & $<.8$ & $<.2$ & $<.8$ & $<.8$ & $<.8$ & $<.8$ & $<.8$ \\
\hline Xylene & $<.8$ & $<.8$ & $<.2$ & $<.8$ & $<.8$ & $<.8$ & $<.8$ & $<.8$ \\
\hline
\end{tabular}

1 U.S. Geological Survey New Jersey District Laboratory.

2 U.S. Geological Survey National Water Quality Laboratory, Avada, Colorado. 
